\title{
Evaluation of Partial Oxidation Reformer Emissions
}

\author{
Final Technical Report for the U.S. Department of Energy \\ Grant Number DE-FC36-99EE50585
}

Reporting Period: 1/27/2000 - 12/31/2004

DOE Project Officer: Nancy Garland

TIAX Project Manager: Stefan Unnasch

Phone Number: 408-517-1563

Fax Number: 408-517-1551

E-Mail: Unnasch.stefan@tiaxllc.com

March 10, 2006

TIAX LLC

1601 S. De Anza Blvd., Ste. 100

Cupertino, California 95014

TIAX Reference: D0014

This report was prepared as an account of work sponsored by an agency of the United States Government. Neither the United States government nor any agency thereof, or any of its contractors/subcontractors, or any of their employees, makes any warranty, express or implied, or assumes any legal liability or responsibility for the accuracy, completeness, or usefulness of any information, apparatus, product, or process disclosed, or represents that its use would not infringe privately owned rights. Reference herein to any specific commercial product, process, or service by trade name, trademark, manufacturer, or otherwise, does not necessarily constitute or imply its endorsement, recommendation, or favoring by the United States Government or any agency thereof. The views and opinions of authors expressed herein do not necessarily state or reflect those of the United States Government or any agency thereof.

Copyright (C) 2006 TIAX LLC. This paper was written with support of the U.S. Department of Energy under Grant Number DE-FC36-99EE50585. The Government reserves for itself and others acting on its behalf a royalty-free, nonexclusive, irrevocable, worldwide license for Governmental purposes to publish, distribute, translate, duplicate, exhibit and perform this copyrighted paper. 


\section{Table of Contents}

Executive Summary ……………………………………........................................... ix

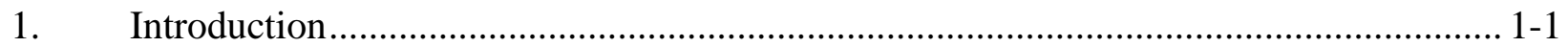

$1.1 \quad$ Goals for On-Board Fuel Processing ................................................................. 1-1

1.1.1 System Operation Parameters ............................................................................ 1-5

$1.2 \quad$ Test Program Objective ................................................................................ 1-8

1.2.1 Cold Start Emissions....................................................................................... 1-9

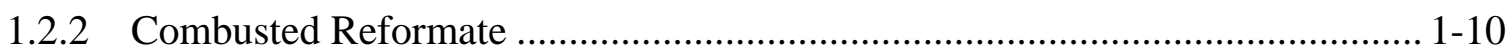

1.2.3 Speciated Emissions.......................................................................... 1-10

1.2.4 Particulate Emissions .................................................................................. 1-10

$1.3 \quad$ Report Outline......................................................................................... 1-11

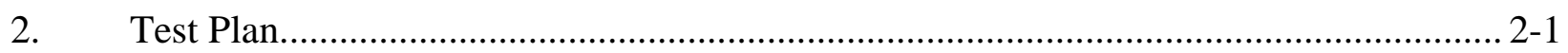

$2.1 \quad$ Test Program ...................................................................................... 2-1

$2.2 \quad$ Instrumentation and Calibration .................................................................. 2-1

2.2.1 Continuous Analyzers................................................................................ 2-2

2.2.2 Hydrocarbon Speciation........................................................................... 2-3

2.2.3 Particulate Matter Measurement ........................................................................... 2-4

2.2.4 Aldehyde and Ammonia Measurement ............................................................. 2-5

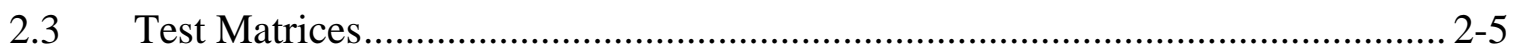

3. Emissions Testing …………………………................................................. 3-1

$3.1 \quad$ Nuvera B System ATR …………………….......................................... 3-1

3.1.1 Data Analysis Considerations ............................................................................. 3-3

3.1.2 Startup Operation ................................................................................... 3-3

3.1.3 Reformate Combustion ................................................................................ 3-4

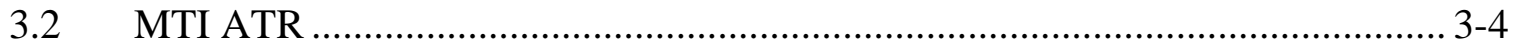

3.2.1 Data Analysis Considerations ......................................................................... 3-6

3.2.2 Startup Operation ................................................................................ 3-6

3.2.3 Reformate Combustion ................................................................................. 3-6

$3.3 \quad$ Nuvera Ethanol Reformer .............................................................................. 3-7

3.3.1 Data Analysis Considerations ....................................................................... 3-8

3.3.2 Startup Operation ...................................................................................... 3-8 
3.4 Nuvera Star Reformer .................................................................................. 3-8

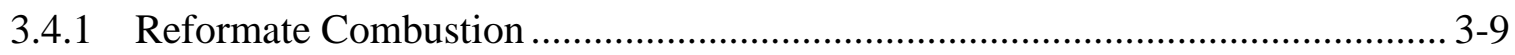

3.5 Emission Testing Results ............................................................................ 3-10

3.5.1 Nuvera B ATR CEM Results................................................................. 3-10

3.5.2 MTI Gasoline Burner CEM Results ................................................................ 3-12

3.5.3 Nuvera Ethanol ATR/PEMFC Anode Gas Burner CEM Results....................... 3-12

3.5.4 Nuvera Gasoline Star ATR Tail Gas Burner CEM Results................................ 3-12

3.6 PrOx Emission Results ........................................................................ 3-16

3.6.1 MTI Gasoline PrOx CEM Results ............................................................... 3-16

3.6.2 Nuvera Ethanol ATR/PEMFC PrOx CEM Results ............................................ 3-16

3.6.3 Nuvera Gasoline Star ATR PrOx CEM Results ................................................. 3-16

3.7 Speciated Hydrocarbon Data Results............................................................... 3-16

3.8 Emission Testing - Interpretation and Discussion............................................ 3-21

3.8.1 Issues with emission testing........................................................................... 3-21

3.8.2 Estimate of On-Board Fuel Processor Emissions ............................................... 3-21

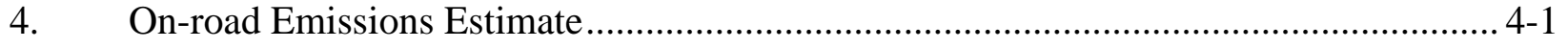

$4.1 \quad$ Startup Emissions.................................................................................... 4-1

4.2 Drive Cycle Modeling.................................................................................... 4-3

4.3 Emission Estimates .................................................................................. 4-8

5. Conclusion and Recommendations ........................................................................ 5-1

Appendix A. Emission Sampling Procedures....................................................................... A-1

Appendix B. DOE Technical Targets................................................................................

Appendix C. Speciation Data Results .................................................................................... 


\section{List of Tables}

Table 1-1. Future Federal and California Emission Standards for Passenger Cars and Light-Duty Vehicles................................................................................ 1-2

Table 1-2. Example of Exit Gas Compositions for a $50 \mathrm{~kW}$ ATR/PEMFC System .............. 1-8

Table 1-3. Fuel Processor Systems Tested ....................................................................... 1-9

Table 2-1. Vehicle Exhaust Emission Standards and Required Detection Limits ................. 2-3

Table 2-2. Detection Limit for Calibration Gases ........................................................2-3

Table 2-3. Calculations to Determine $\mathrm{NO}_{\mathrm{x}}$ Detection Limit ............................................2-3

Table 3-1. CEM and Integrated Emissions Sampling Configurations ................................ 3-1

Table 3-2. Comparison of Combustion Characteristics for the Nuvera B Fuel Processor and an Integrated System ............................................................................. 3-4

Table 3-3. Comparison of Combustion Characteristics for the MTI Fuel Processor and

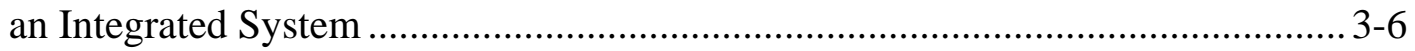

Table 3-4. Comparison of Combustion Characteristics for the Nuvera Fuel Processor and an Integrated System

Table 3-5. Comparison of Combustion Characteristics for the Nuvera Star Fuel Processor and an Integrated System.............................................................. 3-9

Table 3-6. Estimated Emissions from Fuel Cell Vehicle with On-Board Fuel Processor..... 3-21

Table 4-1. Energy Requirements for Future RFG ATR FCVs ........................................ 4-3

Table 4-2. Estimated Emissions from Fuel Cell Vehicle with On-Board Fuel Processor.......4-8 


\section{List of Figures}

Figure 1-1. ATR Fuel Processor/PEMFC Powerplant System........................................... 1-3

Figure 1-2. Equilibrium Gas Composition for Autothermal Reformer ................................ 1-6

Figure 2-1. Fuel Processor System with Sampling Equipment .........................................2-2

Figure 2-2. Particulate Matter Filter Holder .................................................................... 2-4

Figure 2-3. Impinger Schematic for Integrated Sample of Ammonia or Formaldehyde from Exhaust Stream ............................................................................ 2-5

Figure 2-4. Representative Load Curve for an Emissions Sampling Run .............................2-6

Figure 3-1. Prototype of Nuvera B Fuel Processor .......................................................... 3-2

Figure 3-2. Schematic of the Setup of the Nuvera B Fuel Processor Tested in 2000..............3-3

Figure 3-3. Setup Schematic of the MTI ATR Fuel Processor System Tested in 2002 ........... 3-5

Figure 3-4. Reformer and AGB for MTI ATR Fuel Processor System Tested ....................... 3-5

Figure 3-5. Set-up Schematic for the Nuvera Ethanol Fuel Processor Tested in 2003.............3-7

Figure 3-6. Nuvera Ethanol Fuel Processor Integrated with Caterpillar Power Module...........3-7

Figure 3-7. STAR Fuel Processor on Test Stand ................................................................. 3-9

Figure 3-8. CEM Results at Burner Outlet, Nuvera ATR, October 11, 2000 ....................... 3-10

Figure 3-9. CEM Results at Gasoline Burner Outlet (RunB), MTI Gasoline Burner,

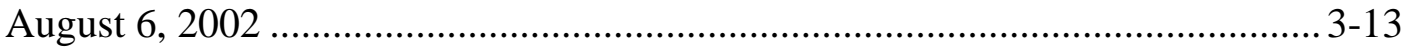

Figure 3-10. CEM Results at Gasoline Burner Outlet (RunD), MTI Gasoline Burner, August 7, 2002

Figure 3-11. CEM Results at Burner Outlet, Nuvera Ethanol ATR PEMFC, February 26, 2003.

Figure 3-12. CEM Results at Burner Outlet, Nuvera Ethanol ATR PEMFC, February 27, 2003

Figure 3-13. CEM Results at Burner Outlet, Nuvera Star ATR, October 14, 2004 .................3-15

Figure 3-14. CEM Results at Burner Outlet, Nuvera Star ATR, October 15, 2004 ................3-15

Figure 3-15. CEM Results at PrOx Outlet (RunA), MTI ATR, August 6, 2002 .................... 3-17

Figure 3-16. CEM Results at PrOx Outlet (RunC), MTI ATR, August 8, 2002 .................... 3-17

Figure 3-17. CEM Results at PrOx Outlet, Nuvera Ethanol ATR, February 25, 2003 ...........3-18

Figure 3-18. CEM Results at PrOx Outlet, Nuvera ATR, October 12, 2004 ......................... 3-18

Figure 3-19. CEM Results at PrOx Outlet, Nuvera Star ATR, October 13, 2004 ................... 3-19

Figure 3-20. CEM Results at PrOx Outlet, Nuvera Star ATR, October 14, 2004 .................. 3-19 
Figure 3-21. Methane and Non-methane hydrocarbon .................................................. 3-20

Figure 3-22. Speciation of non-methane hydrocarbons for various operation modes .............. 3-20

Figure 4-1. Estimated Energy Required to Startup Fuel Processor ...................................... 4-2

Figure 4-2. The Federal Urban Driving Schedule............................................................4-4

Figure 4-3. Motor Power Demand over the FUDS ........................................................ 4-4

Figure 4-4. Fuel Cell/Battery Hybrid Vehicle Architecture ................................................ 4-5

Figure 4-5. Fuel Cell Power Output for a Defined Battery Power Management Strategy for the Motor Power Demand Shown in Figure 2-2 ......................................... 4-6

Figure 4-6. Assumed Fuel Processor Efficiency Versus Processor Load............................... 4-7

Figure 4-7. Fuel Processor Power Input to Supply the Fuel Cell Power Output in Figure 4-4 for the Efficiency Curve in Figure 4-5 .................................................... 4-7 


\section{Abbreviations}

AGB Anode gas burner

ARB California Air Resources Board

ATR Autothermal reformer

CEM Continuous emissions monitor

CNG Compressed natural gas

CO Carbon monoxide

$\mathrm{CO}_{2} \quad$ Carbon dioxide

DOE U.S. Department of Energy

FCVs $\quad$ Fuel cell vehicles

FUDS Federal Urban Driving Schedule

$\mathrm{H}_{2} \quad$ Hydrogen

$\mathrm{H}_{2} \mathrm{O} \quad$ Water

HC Hydrocarbons

HTS High temperature shift

LTS Low temperature shift

$\mathrm{N}_{2} \quad$ Nitrogen

NMOG Non-methane organic gases

NO Nitrous oxide

$\mathrm{NO}_{2} \quad$ Nitrogen dioxide

$\mathrm{NO}_{\mathrm{x}} \quad$ Oxides of nitrogen

PEMFC Proton exchange membrane fuel cell

PM Particulate matter

POX Partial oxidation

PrOx Preferential oxidation reactor

SULEV Super Low Emission Vehicle

TGC Tail gas combustor

THC Total hydrocarbons

ZEV Zero emission vehicle 


\section{Executive Summary}

This project measured the emissions from autothermal fuel processors for PEMFC systems. Both Nuvera and McDermott fuel processors will be tested. One Nuvera system was integrated with a PEM fuel cell, while the other systems were tested decoupled from a fuel cell.

The cold startup and normal operating emissions of $\mathrm{NO}_{\mathrm{x}}, \mathrm{CO}$, and $\mathrm{CO}_{2}$, methane, nonmethane hydrocarbons, carbonyl group compounds (aldehydes), and speciated hydrocarbons (light end hydrocarbon group components and mid-range hydrocarbon group components) from a fuel processor before and after treatment by an anode gas burner were quantified. . Estimates of emissions from fuel cell vehicles with a multi-fuel reformer were made and compared to emission standards.

During normal operation, the fuel processor operates under very rich conditions.. Under these conditions, virtually no $\mathrm{NO}_{\mathrm{x}}$ is formed, although the formation of ammonia is possible. Most hydrocarbons are converted to carbon oxides (or methane if the reaction is incomplete); however trace levels of hydrocarbons can pass through the fuel processor and fuel cell. CO in the product gas is reduced by the shift reactors and PROX, so the feed concentration to the fuel cell can be less than $20 \mathrm{ppm}$. The fuel cell may also convert $\mathrm{CO}$ to $\mathrm{CO}_{2}$, thereby further reducing exhaust $\mathrm{CO}$ levels. Thus, of the criteria pollutants, $\left(\mathrm{NO}_{\mathrm{x}}, \mathrm{CO}\right.$, and hydrocarbon [NMOG]), $\mathrm{NO}_{\mathrm{x}}$ and $\mathrm{CO}$ levels are generally well below the most aggressive standards. NMOG concentrations, however, can exceed emission goals if these are not efficiently eliminated in the catalytic burner. The project results show that fuel cell vehicle with on-board fuel processors can meet stringent emission standards. 


\section{Introduction}

Over the last decade, there have been impressive improvements in the power density of proton exchange membrane fuel cell (PEMFC) stacks, leading to unprecedented interest and investment by the automotive industry for potential light-duty vehicle applications. Furthermore, development of PEMFC systems has progressed so rapidly that the California Air Resources Board (ARB) now considers hydrogen fuel cell vehicles (FCVs) as technological alternatives to battery-electric vehicles in meeting the state's zero emission vehicle (ZEV) requirements over the next 10 years. FCVs with on-board fuel processors could fall under near ZEV certification categories if their emissions are sufficiently low.

Despite the recent progress and future promise in FCVs, most advancements have been limited to prototype systems operating on hydrogen that circumvent the complexity and tradeoffs associated with fuel processing. Although such prototype PEMFC systems offer zero emissions and the highest possible system efficiencies, hydrogen-fueled systems are unlikely to offer broad market appeal, particularly in the near-term, due to the significant costs and challenges associated with a hydrogen infrastructure. As a result, PEMFC engines with an autothermal reformer (ATR) or a partial oxidation (POX) reformer fuel processor are recognized as having potential for automotive applications without being constrained by fuel infrastructure issues. The current focus is on gasoline and methanol fuels, though other fuels are being considered including ethanol and natural gas.

\subsection{Goals for On-Board Fuel Processing}

The specific performance, operating, and cost criteria for automotive fuel cells have been quantified by U.S. automobile manufacturers collaborating with the U.S. Department of Energy (DOE) and other federal agencies under the umbrella of FreedomCAR. At a minimum, emissions from FCVs must comply with the regulations projected to be in place at the time that the technology is available for market introduction. Since California is the most likely point of market entry, this suggests that emissions from FCVs must be well below Federal Tier 2 standards to be able to meet the California LEV II Super Low Emission Vehicle (SULEV) standard. For comparison, these emission standards are listed in Table 1-1.

These pollutants are routinely measured for gasoline and alternative fueled vehicles. The definition of pollutants is briefly summarized here.

- Oxides of nitrogen $\left(\mathrm{NO}_{\mathrm{x}}\right)$ are produced during combustion at elevated temperatures. Nitrogen from the air or fuel reacts with oxygen to form nitrous oxide (NO) or nitrogen dioxide $\left(\mathrm{NO}_{2}\right) \cdot \mathrm{NO}_{\mathrm{x}}$ is reported on an $\mathrm{NO}_{2}$ molecular weight basis.

- Carbon monoxide (CO) is produced in reformers or the product of incomplete fuel combustion.

- Particulate matter (PM) is the soot formed from fuel combustion. The particle size is typically under 10 microns.

- Hydrocarbon emissions results from the incomplete reforming or combustion of fuel. Hydrocarbon emissions are reporting using various methods, depending on the application 
(vehicles, stationary testing, etc.). Total hydrocarbons (THC) are measured with an instrument that responds to methane, non oxygenated hydrocarbons, and oxygenated hydrocarbon. THC is typically reported for gasoline at the vehicle exhaust.

- The reporting of non-methane organic gases (NMOG) is appropriate when the exhaust species contain a high level of oxygenated compounds such as aldehydes, alcohols, or ketones. NMOG represents the sum of these organic compounds, represented without the oxygen component of their molecular weight.

- Methane is excluded from the NMOG representation. Determining NMOG requires a THC measurement in combination with a speciation of the hydrocarbons to determine the methane and oxygenated constituents. Several test methods are required to collect the sample and analyze the compounds as described in Section 2.

\section{Table 1-1. Future Federal and California Emission Standards for Passenger Cars and Light-Duty Vehicles (g/mi)}

\begin{tabular}{|c|c|c|c|c|}
\hline \multirow{2}{*}{ Pollutant $^{\text {b }}$} & \multicolumn{2}{|c|}{ Federal Tier 2: MY2004+ ${ }^{\text {a }}$} & \multicolumn{2}{c|}{$\begin{array}{c}\text { California LEV II: } \\
\text { ULEV and SULEV, MY2004+ }\end{array}$} \\
\cline { 2 - 5 } & $\mathbf{5 0 , 0 0 0}$ miles & $\mathbf{1 2 0 , 0 0 0}$ miles & $\begin{array}{c}\text { ULEV at } \\
\mathbf{1 2 0 , 0 0 0} \text { miles }\end{array}$ & $\begin{array}{c}\text { SULEV at } \\
\mathbf{1 2 0 , 0 0 0} \text { miles }\end{array}$ \\
\hline NO $_{\mathrm{x}}$ & $0.05-0.1$ & $\begin{array}{c}0.00-0.20 \\
(0.07 \text { fleet average })\end{array}$ & 0.07 & 0.02 \\
\hline CO & 3.4 & $0.00-4.2$ & 2.1 & 1.0 \\
\hline PM & - & $0.00-0.02$ & 0.01 & 0.01 \\
\hline NMOG & $0.075-0.100$ & $0.00-0.125$ & 0.055 & 0.010 \\
\hline
\end{tabular}

${ }^{a}$ Values shown reflect range of vehicle weight categories. Temporary bins with higher allowances for heavier vehicles (not shown in ranges) expire after MY2008. As many as 11 bins are available to certification. Tier 2 specifies PM or NMOG levels for the bins, but allows the fleet levels to change with mix needed to meet the fleet average.

${ }^{\mathrm{b}}$ Emission standard was phased in starting with indicated model year

Theoretically, the process of reforming carbonaceous fuels into hydrogen-rich gases suitable for use in a FCV can be done with little or no pollutants. In practice, fuel processor and fuel cell system operation involve auxiliary combustion processes, and thus the potential exists for formation of $\mathrm{NO}_{\mathrm{x}}$ and products of incomplete combustion including $\mathrm{CO}$ and unburned hydrocarbons. Under the chemical conditions and constraints prevailing in properly operating methanol and gasoline powered fuel cells, these emissions should be close to SULEV levels. However, no emissions data currently exist on PEMFC systems with on-board reformers operated under real-world transient conditions, complete with cold starting.

Given this paucity of actual data on the emissions of reformer/PEMFC systems over an entire driving cycle that includes the cold start emissions, achieving appropriately low emissions is not certain. Two factors appear critical to achieving the lowest emission levels. First, residual hydrocarbons from the fuel processor must be combusted or catalytically dissociated. Also, cold start emissions must be sufficiently low as to not impact the overall emission results on a g/mile 
basis. These issues are potential "show-stoppers" that could prevent reformer/PEMFC vehicles from competing in the future clean vehicle marketplace.

An autothermal reformer (ATR) fuel processor/PEMFC system for a vehicle powerplant application consists of a fuel processor, fuel cell, anode gas burner (AGB), and (typically) a compressor/expander module as indicated in Figure 1-1. The AGB is also referred to as a tail gas combustor (TGC) by some developers. The fuel processor consists of a partial oxidation reactor in which fuel, air, and steam react to produce a mixture of $\mathrm{CO}$, hydrogen $\left(\mathrm{H}_{2}\right)$, carbon dioxide $\left(\mathrm{CO}_{2}\right)$, nitrogen $\left(\mathrm{N}_{2}\right)$ and traces of methane and other hydrocarbons. Pressurized air, steam, and fuel are preheated in the fuel processor in order to increase ATR exit temperatures. Preheating minimizes carbon formation and reduces levels of unreacted hydrocarbons and unconverted methane (often referred to as "methane slip"). A variety of ATR configurations have been investigated and described in the literature.

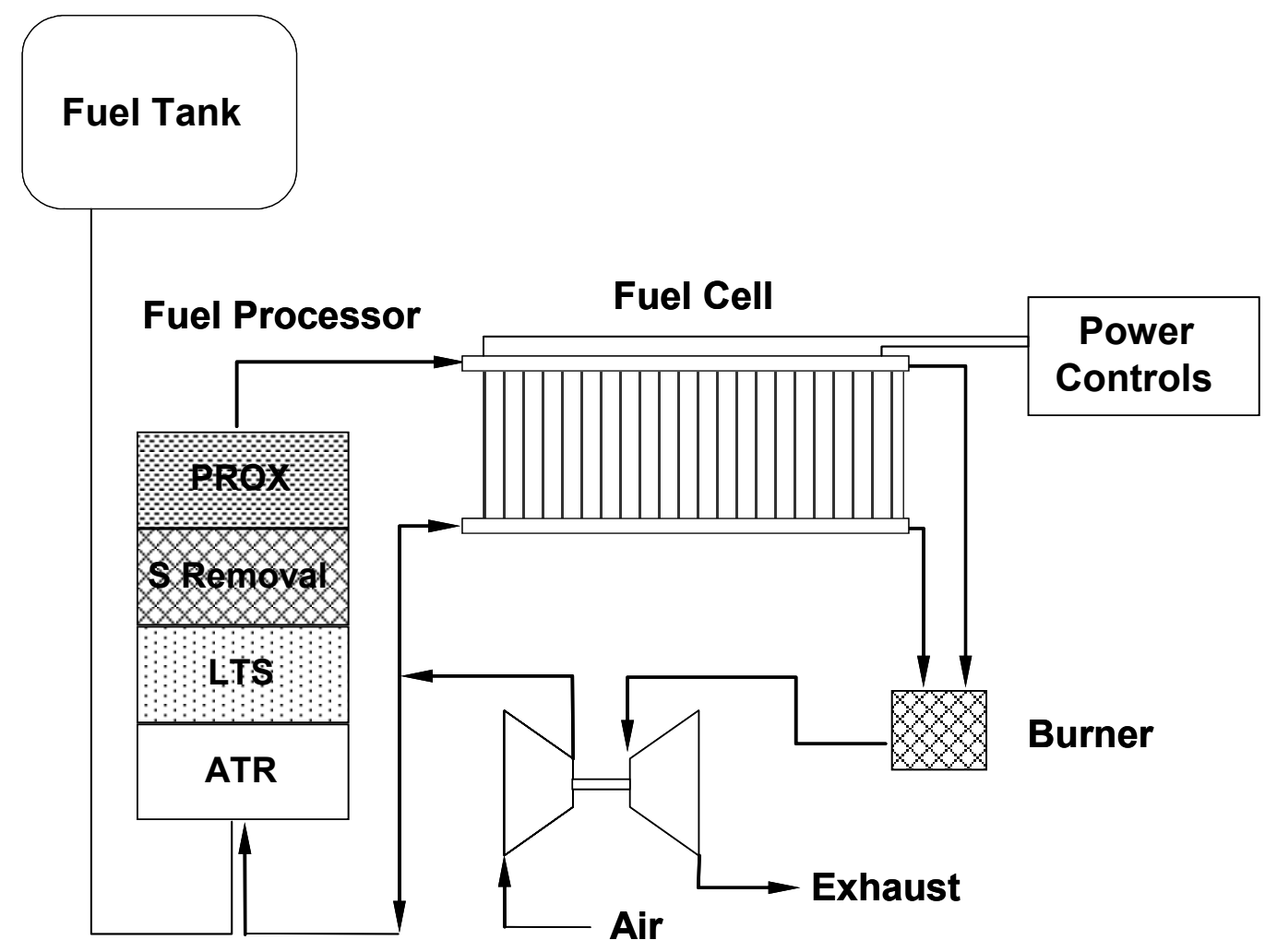

Figure 1-1. ATR Fuel Processor/PEMFC Powerplant System

1 Ahmed, S., R. Ahluwalia, S.H.D. Lee, "Experimental Study to Determine Fast-Start Capability of On-board Fuel Processor,” Fuel Cell Seminar, 2003.

2 Unnasch, S., and V. Drünert, "Evaluation of Fuel Cell Reformer Emissions,” Final Report, prepared for ARB under Contract 95-313, March 1999.

3 Castaldini, M., M. Lyubovsky, R. LaPierre, W. C. Pfefferie, and S. Roychoudhury, Precision Combustion, Inc., "Performance of Microlith Based Catalytic Reactors for an Isooctane Reforming System," SAE Paper 2003-011366.

4 Privette, R. M., T. J. Flynn, M.A. Perna, K. E. Kneidel, D. L. King, and M. Cooper, “Compact Fuel Processor for Fuel Cell-Powered Vehicles, Paper MT100-10, presented at the 1999 DOE/EPRI/GRI Fuel Cell Technology Review Conference, Chicago, IL August 3-5, 1999. 
The remaining steps of the ATR system include one or more reactors that reduce the CO content of the reformer product. Specifically, after cooling, the gas stream typically enters a series of two shift reactors, where additional steam is added to the gas, and the water gas shift reaction is employed to convert $\mathrm{CO}$ to $\mathrm{CO}_{2}$ and additional hydrogen. Two reactors are typically used for the shift reaction to take advantage of higher reaction rates at higher temperatures and lower CO equilibrium concentrations at lower temperatures. The high temperature shift (HTS), operating at about $500^{\circ} \mathrm{C}$, is accelerated with an iron oxide catalyst. Sulfur removal can be accomplished with zinc oxide at $450^{\circ} \mathrm{C}$, although further sulfur removal may be required. Liquid water is injected into the ATR exit gas in order to achieve the temperature drop required for the HTS inlet. Higher water/CO ratios favor a higher hydrogen production. A second shift reactor, the low temperature shift (LTS) reactor can reduce CO levels to about 1 percent. A heat exchanger is employed to cool the HTS-exit gas to temperatures of about $200^{\circ} \mathrm{C}$ before it enters the LTS.

After the shift reactors, the gas flows to a preferential oxidation reactor ( $\mathrm{PrOx}$ ), where additional air is injected to oxidize the remaining $\mathrm{CO}$ to acceptable levels. A selective catalyst favors the reaction of $\mathrm{CO}$ with oxygen rather than the reaction with hydrogen. This reaction occurs at a low temperature, and reduces CO levels from 1 percent to below 100 ppm. The PrOx is also expected to convert an equal volume of hydrogen to water vapor. Thus, if 1 percent $\mathrm{CO}$ is converted to $\mathrm{CO}_{2}, 1$ percent hydrogen will be converted to water vapor. The ratio of hydrogen consumption can be higher if temperature excursions occur in the PrOx.

The exit gas from the fuel processor is fed directly to the anode side of a PEMFC where hydrogen ions pass through the membrane and are converted to water vapor on the cathode side by combining with oxygen from the air. Because even trace amounts of $\mathrm{CO}$ can poison the PEMFC, anode air bleed or other techniques can be employed to reduce the amount of CO even further. The unreacted hydrogen and other product gases from the anode side, combust in a catalytic burner, the AGB. The heated gas from the AGB finally passes through an expander where its pressure drops from (typically) 2.5 to $1 \mathrm{~atm}$, while powering a compressor that provides compressed air for the fuel cell and fuel processor.

Fuel processor/fuel cell system operation is generally divided into two operating modes: startup and normal operation. During startup, the fuel processor burns fuel at near stoichiometric conditions until critical system temperatures and pressures stabilize to target values. Once the target conditions are reached, the fuel processor operates in normal mode in which the fuel is burned under very fuel rich conditions. Since these modes are comprised of considerably different operating conditions, it follows that the emissions associated with each of these modes are also considerably different.

The emissions produced during the brief startup period (target times are under 30 seconds, see Appendix B) can be substantially higher than those produced during the remaining, much longer portion of the driving cycle. The pollutant emissions produced during startup operation can include $\mathrm{NO}_{\mathrm{x}}, \mathrm{CO}$, formaldehyde, and organic compounds. These organic compounds, which include hydrocarbons, alcohols, and aldehydes, are regulated in California and referred to as NMOG.

Under normal operating conditions, in which the reformer is sufficiently warm and operated under fuel rich conditions, virtually no $\mathrm{NO}_{\mathrm{x}}$ is formed, although the formation of ammonia is possible. Most hydrocarbons are converted to carbon dioxide (or methane if the reaction is 
incomplete), but trace levels of hydrocarbons can pass through the fuel processor and fuel cell. The shift reactors and the preferential oxidation ( $\mathrm{PrOx}$ ) reactor reduce $\mathrm{CO}$ in the product gas, with further reduction in the fuel cell. Thus, of the criteria pollutants $\left(\mathrm{NO}_{\mathrm{x}}, \mathrm{CO}\right.$, and hydrocarbons [NMOG]), $\mathrm{NO}_{\mathrm{x}}$ and $\mathrm{CO}$ levels are generally well below the most aggressive standards. While the sensitivity of the PEMFC to CO and hydrocarbons assures that the emission levels are relatively low during normal operation, startup emissions with the fuel cell bypassed can be significant.

The catalytic AGB serves two functions. Its primary function is to oxidize the remaining hydrogen in the fuel cell anode gas to provide energy for the expander that supplies compressed air to the system. In addition, the burner must also reduce NMOG emissions during both startup and normal operation. The AGB operates on a mixture of fuel cell anode gas, which has about 80 percent of the hydrogen that enters the fuel cell, and oxygen depleted cathode gas. This mixture has a very low heating value, so reaction temperatures are low, around $300^{\circ} \mathrm{C}$. The low reaction temperatures assure that no $\mathrm{NO}_{\mathrm{x}}$ is formed. However, the catalyst activity for oxidation of NMOG and CO may be diminished at these low temperatures.

\subsubsection{System Operation Parameters}

During normal operation, the following reactions occur in an integrated fuel processor/fuel cell system.

\section{$\underline{\text { Fuel Input }}$}

Fuel is mixed with steam and vaporized. A fuel pump (or regulator for compressed natural gas [CNG]) provides fuel at 3 to $10 \mathrm{~atm}$. The presence of steam inhibits coking of the fuel. Waste heat from the AGB can provide the heat for fuel vaporization.

\section{$\underline{\text { Autothermal Reformer (ATR) }}$}

A mixture of fuel, air, and steam reacts in the ATR to produce $\mathrm{H}_{2}$, $\mathrm{CO}$, and $\mathrm{CO}_{2}$. The system is referred to as autothermal because heat generated from the partial oxidation of fuel is balanced with the endothermic reaction of reforming methane with steam. Excess water, unreacted hydrocarbons, and nitrogen from the air are present in the product mixture. Many configurations of ATR systems have been investigated. The ATR can be configured in a multi staged approach where air and fuel first react, followed by the addition steam as the mixture flows over a catalyst. The excess heat from the ATR is typically used to preheat air and steam to improve the overall efficiency of the system. 
The performance of the ATR system depends on a variety of factors including the reactor operating temperature, air/fuel ratio, performance of the reforming catalyst, thermal integration of the reactor, and the gas clean up reactors. Figure 1-2 plots the equilibrium gas compositions for gasoline reforming illustrating the effect of air/ fuel ratio on hydrogen production. The reformer temperature rises as the air/fuel ratio rises. Peak $\mathrm{H}_{2}$ and $\mathrm{CO}$ product is achieved at a stoichiometric ratio below 0.3. Reducing this value too far results in a lower temperature in the reformer and increases the potential for soot formation. Gas compositions and operating conditions for a variety of reformer systems are described in the literature. ${ }^{5,6,7,8}$

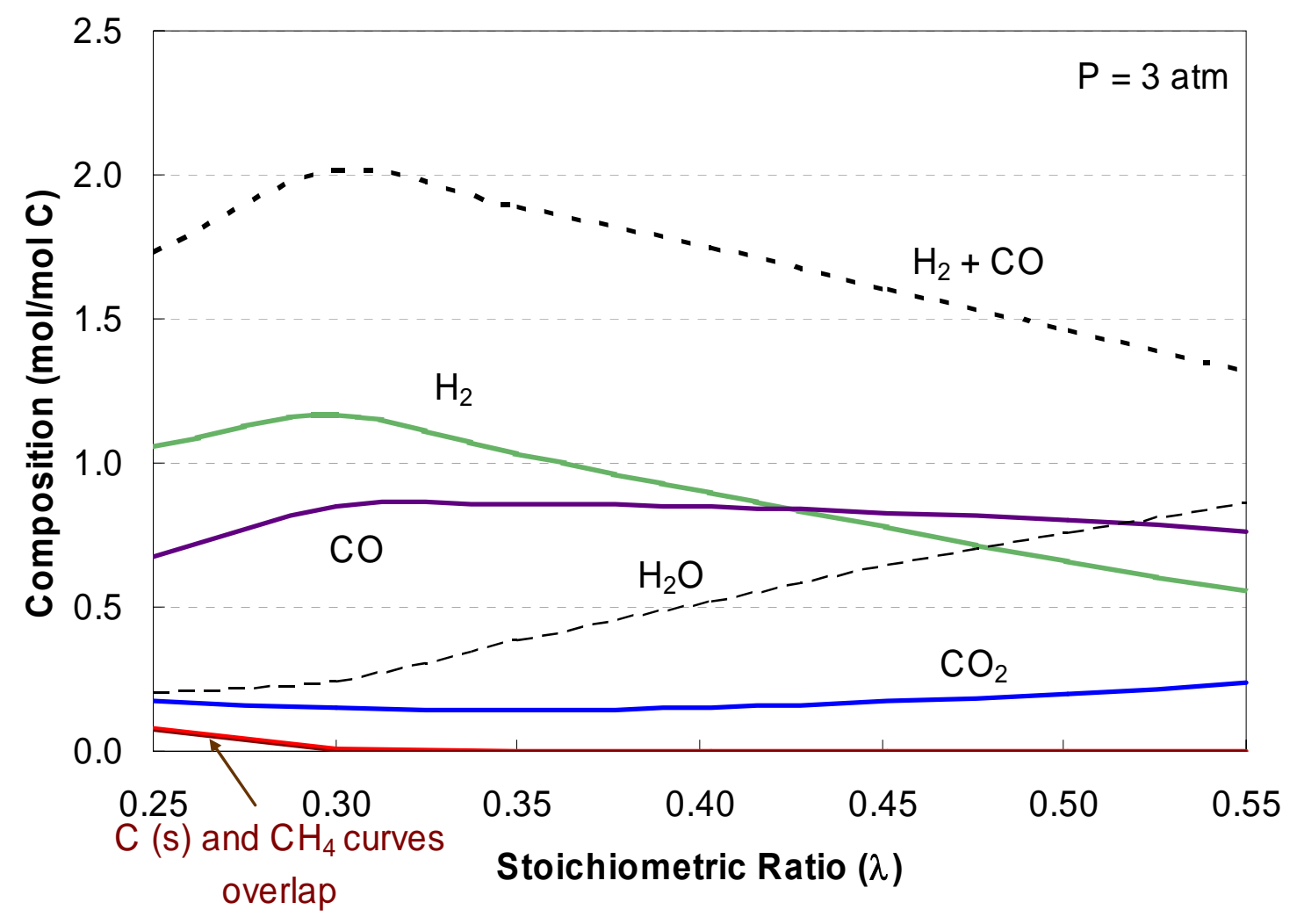

Figure 1-2. Equilibrium Gas Composition for Autothermal Reformer (gasoline fuel)

5 Milind V. Kantak and John R. Budge, McDermott Technology Inc., "Catalytic Partial Oxidation (CPOX) Reformer Development,” Fuel Cell Seminar, 2003.

6 Unnasch, S., and V. Drünert, "Evaluation of Fuel Cell Reformer Emissions,” Final Report, prepared for ARB under Contract 95-313, March 1999.

7 Anca Faur-Ghenciu, Ph.D., "Fuel Processing Catalysts for Hydrogen Reformate Generation for PEM Fuel Cells,” Fuel Cell Magazine, April/May 2003.

8 Castaldini, M., M. Lyubovsky, R. LaPierre, W. C. Pfefferie, and S. Roychoudhury, Precision Combustion, Inc., "Performance of Microlith Based Catalytic Reactors for an Isooctane Reforming System," SAE Paper 2003-011366. 


\section{$\underline{\text { Sulfur Removal }}$}

Sulfur and other contaminants affect the performance and life of components in the fuel processor/fuel cell system. While some developers consider their ATR catalysts to be sulfur tolerant ${ }^{9}$, sulfur must be removed prior to the LTS, PrOx and PEM fuel cell. The removal of sulfur is typically accomplished with a zinc oxide bed at $450^{\circ} \mathrm{C}$.

\section{$\underline{\text { Shift Reactors (HTS, LTS) }}$}

Catalysts in these reactors convert $\mathrm{CO}$ to $\mathrm{CO}_{2}$ via the water gas shift reaction:

$$
\mathrm{CO}+\mathrm{H}_{2} \mathrm{O} \rightarrow \mathrm{CO}_{2}+\mathrm{H}_{2}
$$

The HTS and LTS reactions occur at approximately $500^{\circ} \mathrm{C}$ and $250^{\circ} \mathrm{C}$, respectively. The reaction of $\mathrm{CO}$ with water reduces $\mathrm{CO}$ concentration and produces additional hydrogen for the fuel cell. CO levels can be reduced to about 0.5 percent in and LTS reactor depending upon its operating temperature and configuration.

\section{Preferential Oxidation (PrOx)}

CO levels are further reduced in a preferential oxidation reactor. The PROX converts CO via the reaction:

$$
\mathrm{CO}+1 / 2 \mathrm{O}_{2} \rightarrow \mathrm{CO}_{2}
$$

Air is introduced to the $\mathrm{PrOx}$ and the reaction with $\mathrm{CO}$ is selective. However, some of the hydrogen in the gas stream also reacts with oxygen.

\section{$\underline{\text { PEM Fuel Cell }}$}

The reformer product from the PrOx is fed into the anode of a PEM fuel cell. Because even trace amounts of $\mathrm{CO}$ can poison the PEMFC, anode air bleed or other techniques can be employed to reduce the amount of $\mathrm{CO}$ further. Hydrogen (protons) from the gas stream passes through the fuel cell membrane to react with oxygen on the cathode side. About 80 percent of the hydrogen is consumed with the balance remaining in the anode exit gas. The other products of reforming, nitrogen, unreacted hydrocarbons, and $\mathrm{CO}_{2}$ pass through the fuel cell anode generally unaffected by the membrane catalyst.

\section{Anode Gas Burner (AGB)}

The AGB operates on a mixture of fuel cell anode gas, which has about 80 percent of the hydrogen that enters the fuel cell, and oxygen depleted cathode gas. This mixture has a very low heating value, so reaction temperatures are low, around $300^{\circ} \mathrm{C}$.

9 U.S. Patent Application 20040047799, Surjit Randhava, et al., “Dynamic Sulfur Tolerant Process and System with Inline Acid Gas-Selective Removal for Generation Hydrogen for Fuel Cell,” March 11, 2004. 
The composition of a generic ATR system is shown in Table 1-2, which illustrates the process conditions that affect emissions. These gas compositions were used to assess system flow rates and sampling requirements. Note the following key points:

- Process conditions affect combustion temperature and potential for $\mathrm{NO}_{\mathrm{x}}$ formation and $\mathrm{HC}$ destruction.

- Fuel processor stream has $5 \mathrm{x}$ energy content as AGB stream.

- AGB inlet is oxygen depleted.

- Mass flow of hydrocarbons from PROX provides an estimate for the upper limit on hydrocarbon from fuel cell system.

Table 1-2. Example of Exit Gas Compositions for a 50 kW ATR/PEMFC System

\begin{tabular}{|c|c|c|c|c|}
\hline Stream & ATR & PrOx & $\begin{array}{l}\text { Fuel Cell } \\
\text { (Anode) }\end{array}$ & AGB \\
\hline \multicolumn{5}{|c|}{ Composition (\%) } \\
\hline $\mathrm{H}_{2}$ & 26.5 & 36.3 & 8 & 0 \\
\hline $\mathrm{CO}$ & 16.5 & 0.1 & 0.2 & $<0.1$ \\
\hline $\mathrm{CO}_{2}$ & 7.1 & 20.1 & 29 & 4.0 \\
\hline $\mathrm{O}_{2}$ & 0 & 0 & 0 & 4.0 \\
\hline $\mathrm{N}_{2}$ & 49.7 & 44.0 & 63 & 92 \\
\hline $\mathrm{HC}+\mathrm{CH}_{4}$ & 0.3 & 0.3 & 0.4 & $<0.1$ \\
\hline Temperature $\left({ }^{\circ} \mathrm{C}\right)$ & 650 & 250 & 80 & 300 \\
\hline
\end{tabular}

Source: TIAX process model for ATR system

Since we tested some of the fuel processor systems without a fuel cell system to simulate startup mode, the data requires additional interpretation.

- $\mathrm{NO}_{\mathrm{x}}$ from burning the PrOx exit gas with air will be higher than integrated systems because integrated systems use hydrogen-depleted anode gas, which yields lower combustion temperatures.

- Hydrocarbon emissions from burning the PrOx exit gas will likely be lower than burning Anode gas and Cathode air. However, fuel cell systems may have a catalytic burner which can further reduce hydrocarbon emissions.

\section{$1.2 \quad$ Test Program Objective}

The objective of this project is to provide the currently lacking emissions performance data from fuel processor /PEMFC systems applicable for use in FCVs. Specifically, the emissions, including the cold start emissions, from four fuel processors, two including PEMFCs fueled by the hydrogen-rich reformate, were measured. Clearly, the emissions from the fuel processor/PEMFC systems tested are representative of FCV emissions, however, even in the absence of a fuel cell, the startup emissions from the fuel processor are representative of the system's cold start emissions because the fuel cell is bypassed or passive during startup. The 
emissions from the fuel processor represent an upper bound (worst case) during other portions of the driving cycle. Thus, this project provides the needed data on potential FCV full-cycle emissions. The four fuel processor/fuel systems tested are listed in Table 1-3. Descriptions of the development programs are available from DOE’s annual review meetings. ${ }^{1011,12}$

Table 1-3. Fuel Processor Systems Tested

\begin{tabular}{|l|c|c|c|c|}
\hline \multicolumn{1}{|c|}{ System } & Date Tested & $\begin{array}{c}\text { Fuel } \\
\text { Processed }\end{array}$ & AGB Feed & Power Rating \\
\hline Nuvera B System ATR & $\begin{array}{c}\text { October } \\
2000\end{array}$ & Gasoline & $\begin{array}{c}\text { Gasoline Startup; } \\
\text { PrOx Reformate }\end{array}$ & $50 \mathrm{kWe}$ \\
\hline $\begin{array}{l}\text { McDermott Technology, Inc. } \\
\text { (MTI) ATR }\end{array}$ & $\begin{array}{c}\text { September } \\
2002\end{array}$ & Gasoline & Gasoline & $\begin{array}{c}50 \mathrm{kWe} \text { Tested } \\
\text { @ 10kWe PrOx }\end{array}$ \\
\hline $\begin{array}{l}\text { Nuvera/Caterpillar ATR with } \\
\text { integrated PEMFC }\end{array}$ & $\begin{array}{c}\text { January } \\
2003\end{array}$ & Ethanol & $\begin{array}{c}\text { Ethanol Startup; } \\
\text { PEMFC Anode } \\
\text { Gas }\end{array}$ & $10 \mathrm{kWe}$ \\
\hline Nuvera STAR ATR & $\begin{array}{c}\text { October } \\
2004\end{array}$ & Gasoline & $\begin{array}{c}\text { Gasoline Startup; } \\
\text { PrOx Reformate }\end{array}$ & $50 \mathrm{kWe}$ \\
\hline
\end{tabular}

Unfortunately, only one system was made available to us that included an integrated PEMFC with the fuel processor. All other fuel processor systems were tested by burning the PrOx exit gas with air. In one test, the lab was not configured to burn the PrOx exit gas.

Emission testing was conducted to assess the key issues associated with vehicles equipped with on-board fuel processors. These key issues are described in the subsections below.

\subsubsection{Cold Start Emissions}

An on-board reformer system will need to be heated to a temperature that is high enough for the ATR to operate. As a result, pollutant emissions are greater during system warm-up than after warm-up. In vehicle applications, these emissions are commonly referred to as cold start emissions. In order to determine the relation between cold start emissions and emissions from a system with a fully-heated ATR, system cold start emissions were measured whenever possible, starting with the initial reformer startup.

The duration of the cold start period and the magnitude of the cold start emissions are affected by warm up requirements, and will depend on catalyst mass. Future reformer technology could reduce mass or involve parallel systems for rapid startup. The energy requirement for startup was analyzed in this report and compared to the observed startup emissions.

10 Chintawar, P. S., B. Bowers, A. Xue, W. Mitchell, J. Zhao, M. Ruffo, D. Dattatraya, and V. Sweetland, Nuevera Fuel Cells, Inc., “Advanced High Efficiency Quick-Start Fuel Processor for Transportation Applications, DOE FY2004 Progress Report.

11 Milind V. Kantak and John R. Budge, McDermott Technology Inc., “Catalytic Partial Oxidation (CPOX) Reformer Development,” Fuel Cell Seminar, 2003.

12 Ahmed Amrani and Thomas Richards, Caterpillar Inc., "Proton Exchange Membrane Fuel Cell Power System on Ethanol,” DOE FY 2003 Progress Report. 


\subsubsection{Combusted Reformate}

Gas stream emissions were sampled after the PrOx and after the AGB. Criteria pollutant concentrations in the combusted reformate stream can vary over the driving cycle. As a result, these emissions needed to be monitored over a range of operating conditions, such as transient power loads, to asses the potential impact on emissions. The emission sampling test plans incorporated both transient load changes and steady-state operation in order to capture this effect. Although the profiles did not follow a standard vehicle driving cycle, a combination of steadystate and transient load profiles represented a reasonable cycling of the fuel processor that would be expected from an on-board fuel processor.

\subsubsection{Speciated Emissions}

Hydrocarbons are one of the most challenging pollutants to control from and ATR system. The ATR cracks gasoline or other fuels into $\mathrm{CO}, \mathrm{CO}_{2}$, and methane, leaving a fraction of the fuel as unreacted hydrocarbons. These hydrocarbons would pass through the PEMFC and be burned in the AGB. This two step burning process provides the potential for achieving low emissions. However, the most stringent emissions standards are also at very low levels.

One of the key challenges in determining hydrocarbon emissions lies in distinguishing nonmethane hydrocarbons from methane. Total hydrocarbons (THC) are typically measured from vehicles. For conventional gasoline vehicles, the THC measurement corresponds almost entirely to smog forming non-methane hydrocarbons (about 90 percent). For an ATR system, the fraction of non-methane hydrocarbons to THC may be below 10 percent. Therefore, the THC measurement alone is not an appropriate measurement of the smog forming potential unless the non-methane fraction is taken into account.

The composition of hydrocarbons was determined by gas chromatograph (GC) analysis. The GC analysis was performed by a laboratory that had extensive experience with the methods for vehicle exhaust speciation. Since a very low detection limit (see Table 1-1) is required to distinguish the non-methane hydrocarbon components, performing the speciation with on on-site GC was considered too time consuming for the wide variety of sites tested under this program.

Alcohols, aldehydes, and ammonia are soluble in water. Therefore, preserving these samples for analysis is challenging when the gas stream contains a high moisture content. The alcohol (or other water soluble component) can be absorbed in condensed water anywhere in the sampling system. Therefore, sampling lines must be heated and then samples must be collected by bubbling gas though an impinger train or absorbent cartridge. Separate methods are used for each of these categories of pollutants. Aldehydes and alcohols are also an important pollutants that need to be measured with impinger capture because they are water soluble

\subsubsection{Particulate Emissions}

Measuring particulates is challenging because these pollutants are a combination of solids and vapor phase liquids that condense at lower temperature. Particulate matter (PM) emissions are determined by drawing a gas sample through a filter and weighing the filter before and after sampling. Collecting a representative sample is challenging because isokinetic conditions of the gas stream must be maintained to measure all of the particulate. Furthermore, PM can absorb water which will affect its mass. 
For vehicle tests, PM emission are typically measured in a dilution tunnel with constant volume sampling. The dilution tunnel method cools the exhaust and prevents the condensation of water vapor. The dilution tunnel also provides a constant volume where the vehicle exhaust is mixed with dilution air. With this approach, only the average emissions from the tunnel need to be measured and the vehicle can operate through transients of a drive cycle. Since developmental fuel processor systems were tested for this project, they were subjected to only limited transient operation. Stationary source emission methods, suitable for steady state operation, were used to measure particulates and other pollutants.

\subsection{Report Outline}

This report includes a description of the procedures for measuring emissions, test results, and an interpretation of the results. Section 2 includes an overview of the test plan. Similar test procedures were used for all four reformer systems and differences noted as they apply to each system.

The emissions tests performed on each of these systems are discussed in Section 3. As noted above, emission measurements were made on each system over various duty cycles and quantified in terms of molar concentration (ppm or percent by volume). However, the emission standards that will need to be met, noted in Table 1-1, are g/mi standards over a standard vehicle driving cycle. Section 4 describes the methodology by which emissions in molar concentration are translated into driving cycle $\mathrm{g} / \mathrm{mi}$ emissions estimates. Overall project results, conclusions, and recommendations are discussed in Section 5. 


\section{Test Plan}

Four ATR systems were tested at developer sites. During the emissions testing, the developers provided fuel for the fuel processor/fuel cell system operation at their test sites. Host site technicians operated the fuel processor and ensured that the reformer and related components remained in working order. Host site technicians also recorded reformer power and other performance parameters, including air, steam, and fuel flows into the fuel processor and provided these data to TIAX as the end of the testing. TIAX ensured that the emission sampling systems operated with the fuel processor.

\subsection{Test Program}

During the tests performed, the fuel processor was started from a cold condition, allowed to warm up to target conditions for reforming operation, then cycled over a load demand curve that included low, intermediate, and high loads. All tests were conducted with the fuels listed under Table 1-2 for both the fuel processor and AGB warm up. Both rapid and gradual load changes, or transients, were tested. Host site technicians operated the fuel processor and monitored the following process operating parameters: fuel (gasoline or ethanol) feedrate to both the fuel processor and the $\mathrm{AGB}$, air flow rate to the $\mathrm{AGB}$, and exit gas temperatures from the PrOx and the AGB. Process operating parameter data were recorded at 1 to 10 second intervals in a data acquisition system.

Process gas (PrOx exit) and exhaust gas (AGB exit) compositions were measured using procedures that generally followed the gasoline-fueled Otto cycle engine specifications given in 40 CFR Part 86, Subpart N, modified without dilution air addition. Gas stream concentrations of oxygen $\left(\mathrm{O}_{2}\right), \mathrm{CO}_{2}, \mathrm{CO}, \mathrm{NO}_{\mathrm{x}}$, and THC were continuously monitored in the AGB exit gas or PrOx exit gas, depending upon which stage of the test matrix was being performed. The continuous emission monitoring methods are based on 40 CFR Part 60, and detailed in Appendix A.

During system operation, continuous emissions monitor (CEM) data were recorded at a 5- to 60-second interval. The data-recording interval varied by test site. During the post-sampling data analysis, these CEM data were correlated with the process operating data collected by the host site's data acquisition system.

\section{$2.2 \quad$ Instrumentation and Calibration}

Startup emissions from the fuel processor system were monitored at sampling locations after the PrOx and after the AGB as illustrated in Figure 2-1. Standard source testing instruments were suitable for monitoring most gas compositions. A description of the instruments used during testing, and the calibration of each is given below. Details about the specific calibration methods and instruments used are described in Appendix A. 


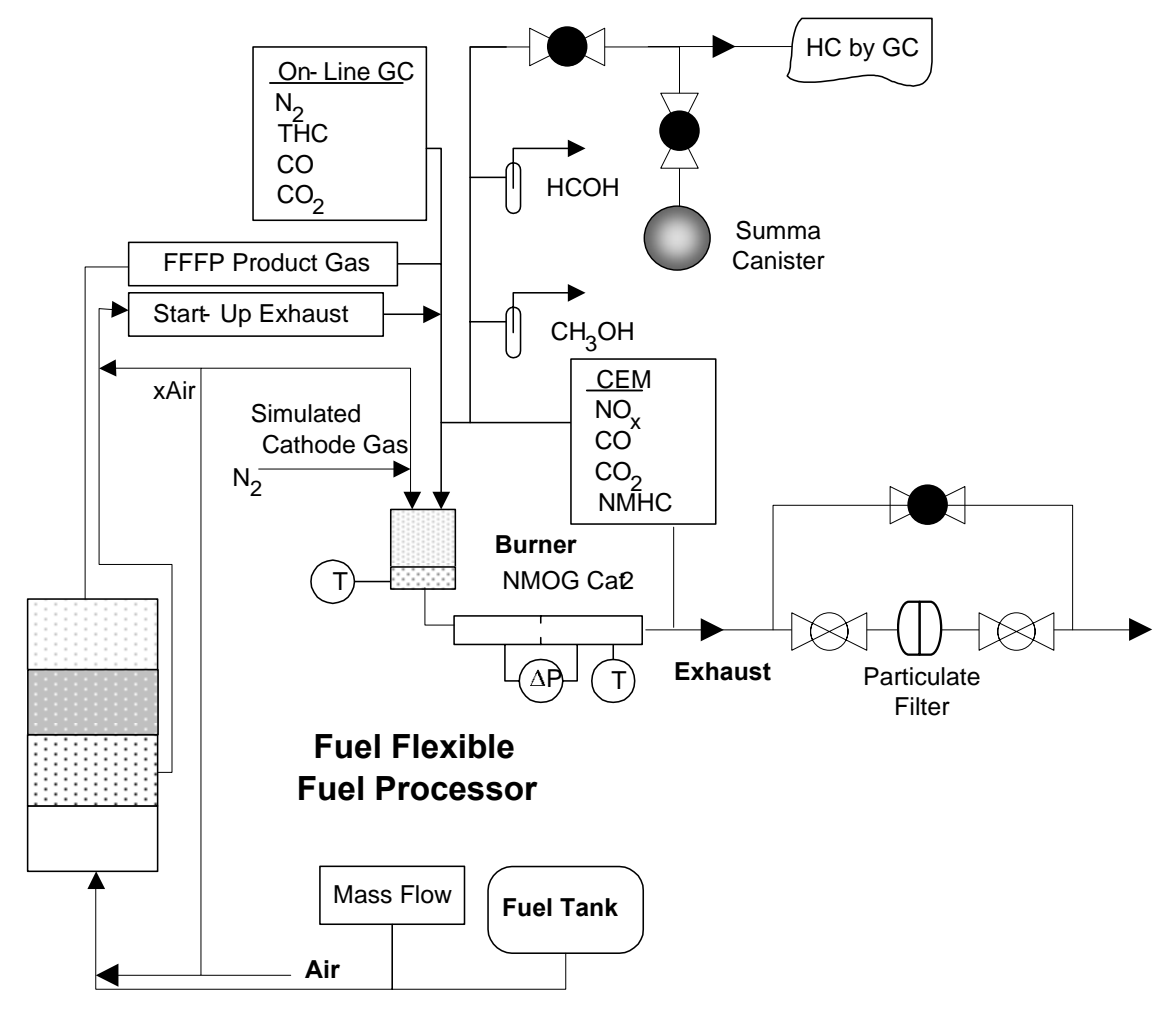

Figure 2-1. Fuel Processor System with Sampling Equipment

\subsubsection{Continuous Analyzers}

Analyzers for $\mathrm{O}_{2}, \mathrm{CO}_{2}, \mathrm{CO}, \mathrm{NO}_{\mathrm{x}}$, and $\mathrm{THC}$ were selected to accommodate the anticipated concentrations of these species. In order to ensure that our analyzers would detect concentrations at or below the equivalent vehicle standards, we estimated the equivalent vehicle exhaust flow rate per mile. We assumed that emission measurements would need to be sensitive enough to determine if fuel cell vehicles could meet the most stringent emission standards. Table 2-1 shows the emission levels that correspond to DOE's goals as well as more stringent standards, including our estimate for the target certification levels that would be needed to comply with the California PZEV standard. We selected a detection level at 5 percent of the target for certification testing. Calibration gases were consistent with detection limit requirements.

Gas flowrates were determined from monitoring of fuel and air flow from the ATR developers. Using this flow rate we converted the vehicle standards from $\mathrm{g} / \mathrm{mile}$ to ppmv in the exhaust. We then selected analyzers with detection thresholds at or below those concentrations. The resulting emission-standard based detection limits are shown in Table 2-2.

Table 2-3 illustrates the calculations to determine the detection limit target for $\mathrm{NO}_{2}$ analyzers. The detection limit is based on the $\mathrm{g} / \mathrm{mi}$ emission level needed to achieve the California SULEV standard. The dilution of the exhaust gas with reformer products is taken into account. Compared to typical emissions sampling provided for stationary sources, $\mathrm{NO}_{\mathrm{x}}$ and $\mathrm{HC}$ required more sensitive equipment than typical measurements. 
Table 2-1. Vehicle Exhaust Emission Standards and Required Detection Limits

\begin{tabular}{|c|c|c|c|c|}
\hline \multirow[b]{2}{*}{ Vehicle } & \multicolumn{2}{|c|}{ NMOG, $\mathrm{g} / \mathrm{mi}$} & \multirow{2}{*}{$\begin{array}{c}\mathrm{NO}_{\mathrm{x}}, \mathbf{g} / \mathrm{mi} \\
\text { Tailpipe }\end{array}$} & \multirow{2}{*}{$\begin{array}{c}\text { PM, g/mi } \\
\text { Tailpipe }\end{array}$} \\
\hline & Tailpipe $^{1}$ & Evaporative & & \\
\hline PNGV Goal/CA LEV Standard & 0.08 & $2 \mathrm{~g} / \mathrm{test}$ & 0.07 & 0.01 \\
\hline PZEV Standard & 0.01 & 0.0 & 0.02 & 0.01 \\
\hline PZEV Certification Target & 0.0065 & $0.0164^{2}$ & 0.017 & 0.01 \\
\hline Estimated Detection Limit & 0.0003 & - & 0.0008 & 0.0003 \\
\hline
\end{tabular}

${ }^{1}$ Emission standards represent maximum emission levels over the vehicle life. Tailpipe emissions are tested over the FUDS cycle. For PZEVs, the emission standards apply for 150,000 miles.

2 Based on detection limits for certification testing. Actual levels may be lower.

Table 2-2. Detection Limit for Calibration Gases

\begin{tabular}{|l|l|l|}
\hline \multirow{2}{*}{ Pollutant } & \multicolumn{2}{|c|}{ Detection Limit } \\
\cline { 2 - 3 } & $\mathbf{( g / m i )}$ & (ppm) \\
\hline \hline $\mathrm{NO}_{\mathrm{x}}$ & 0.00026 & 0.13 \\
$\mathrm{CO}$ & 0.0016 & 1.30 \\
$\mathrm{NMHC}$ & 0.00029 & 0.13 \\
\hline
\end{tabular}

Table 2-3. Calculations to Determine $\mathrm{NO}_{\mathrm{x}}$ Detection Limit

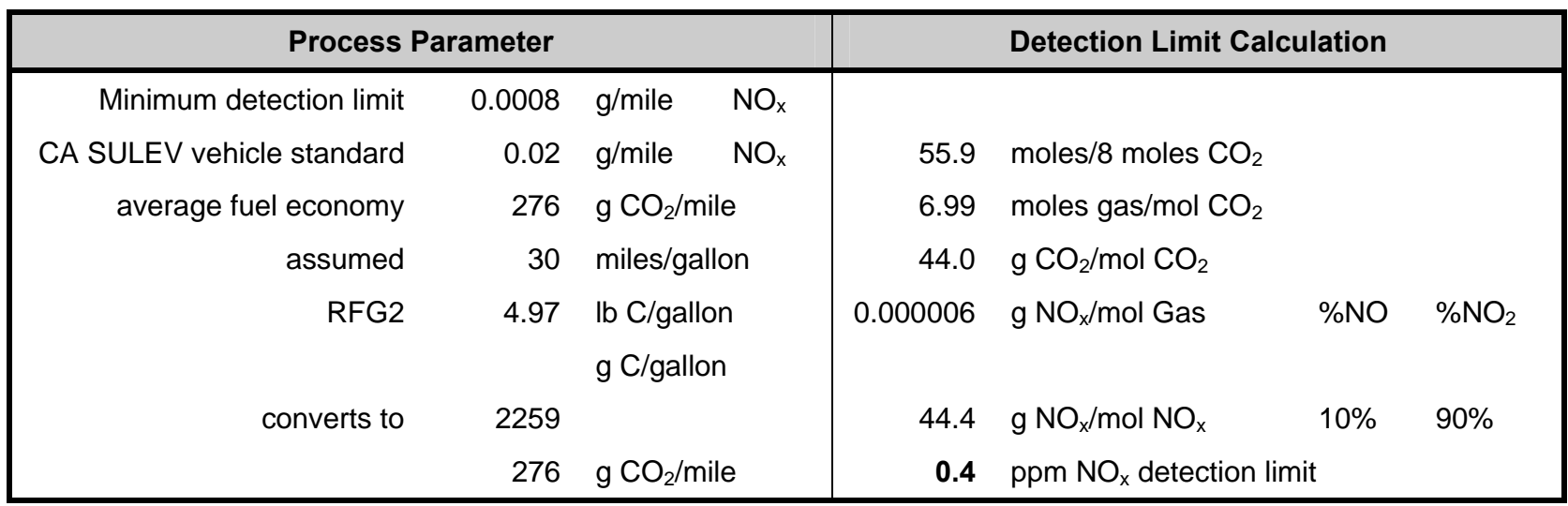

\subsubsection{Hydrocarbon Speciation}

Speciated HC analysis was performed on integrated samples collected during fuel processor testing. These samples were collected over specific time intervals using Tedlar bags (for the Nuvera 2000 test) or evacuated Summa canisters. Evacuated Summa canisters and Tedlar bags were provided by Air Toxics Ltd., of Roseville, CA, the analysis laboratory that provided the 
speciated HC analysis of the canister samples via GC/MS. Samples were taken using standard extraction methods as indicated by Air Toxics; these standard methods are summarized at the start of Section 3. The analysis results allowed a comparison of the relative proportions of HC types as well as the methane to non-methane ratio. Alcohols were also included in this speciation for the 2003 Nuvera Ethanol PEMFC system. These specific results are also discussed in Section 3.

\subsubsection{Particulate Matter Measurement}

In this study, exhaust gas filterable PM was measured by passing the entire exhaust gas stream through a quartz fiber filter that met the specifications required by EPA Method 17. A photograph of the filter holder and filter media are given in Figure 2-2. The filter collected particulate over the entire startup and load cycle test, giving a single filterable particulate measurement over a test run's duration.

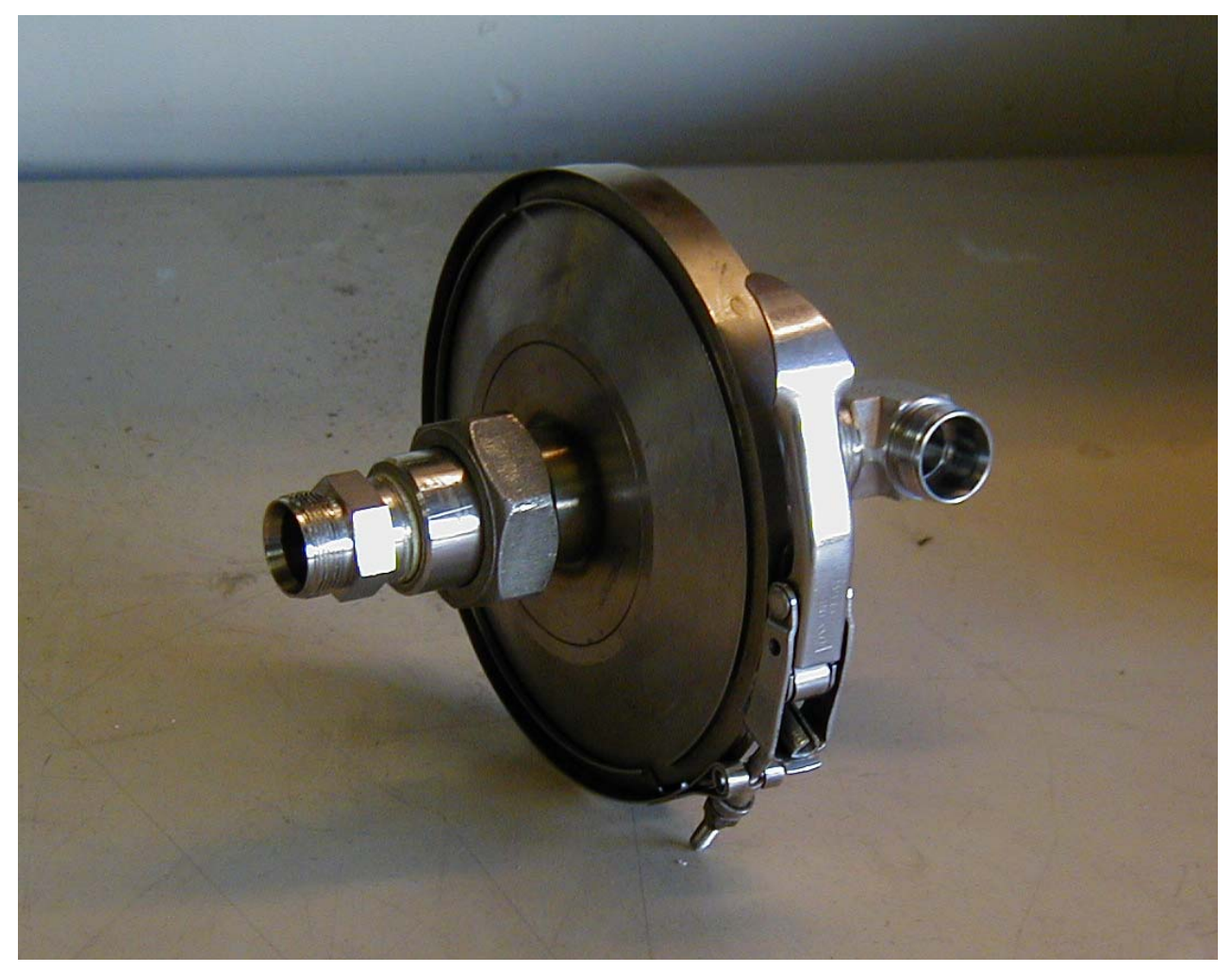

Figure 2-2. Particulate Matter Filter Holder

This total-flow filtration technique was selected instead of a partial flow sample method in order to facilitate comparison between samples taken under different flow rates on a given system.

Measuring the PM concentration using a fraction of the total system exhaust flow would require knowledge of the flow rate through the filtration pathway, temperature, and pressure drop. This would have required additional sampling equipment and corrections for the differences in flow conditions between runs, thereby adding complexity to the sampling system and introducing 
additional potential for error. In order to avoid adding complexity to the monitoring system, we decided to filter the entire flow, at a point where the host site was already monitoring the relevant supporting parameters.

\subsubsection{Aldehyde and Ammonia Measurement}

In order to measure the formaldehyde, ammonia, and alcohol concentrations, an integrated sample of gas was collected through a series of chilled glass impingers. A simple schematic of the impinger arrangement is shown in Figure 2-3. These impingers directed the sample through a collection liquid, either $0.1 \mathrm{~N} \mathrm{HCl}$ for the ammonia collection and a Sep-Pak (MTI ATR 2002)/DNPH solution (Nuvera Ethanol ATR/PEMFC 2003 and Nuvera Star ATR 2004) provided by Air Toxics to capture formaldehyde. The total flow volume was measured as it passed out of the impingers. The integrated sample was collected over a period between 30 minutes to 1 hour for each sample.

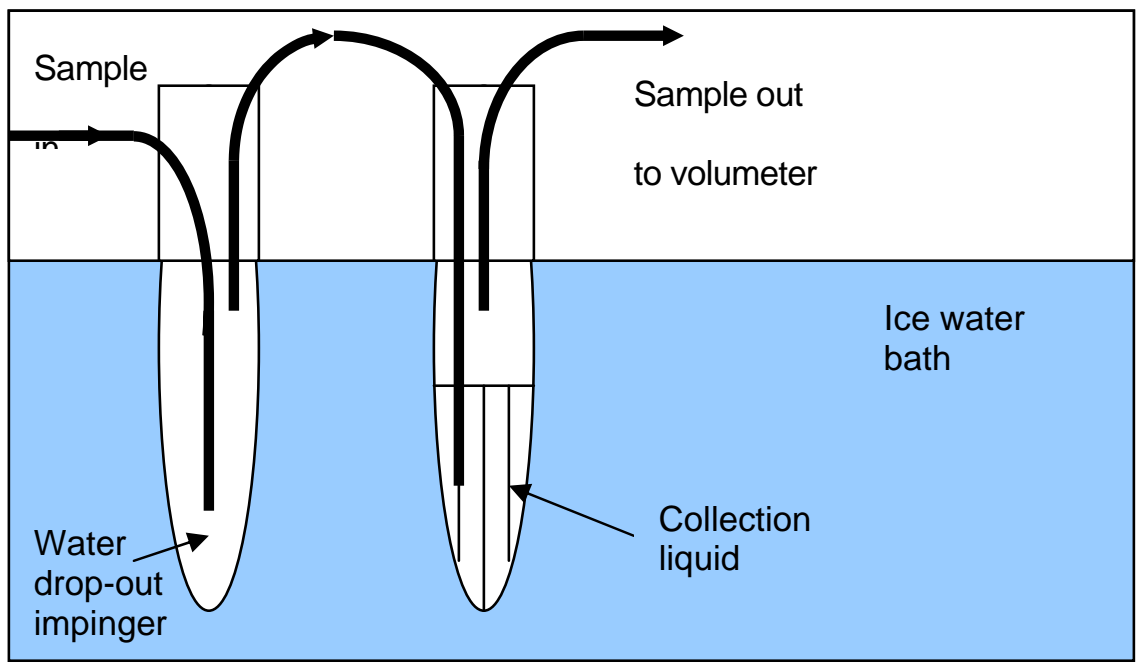

Figure 2-3. Impinger Schematic for Integrated Sample of Ammonia or Formaldehyde from Exhaust Stream

\section{$2.3 \quad$ Test Matrices}

A representative sequence of test runs is provided as graphs of load and sampling points versus time in Appendix A (see Figure 2-4). The test runs were comprised of target steady-state loads and load changes that were adapted at the time of sampling to the reformer's running condition. Sampling occurred throughout normal operations, with the exception of formaldehyde and ammonia samples, which were taken only during steady-state operation.

As the fuel processor operated at a series of load points for each of the emissions test runs, TIAX extracted gas samples from the PrOx outlet and the exhaust burner outlet. Testing was conducted using ethanol or gasoline. The properties of these fuels are listed in Appendix A. During each run, the exhaust burner outlet or the PrOx outlet was be continuously monitored for total $\mathrm{HC}, \mathrm{NO}_{\mathrm{x}}, \mathrm{O}_{2}, \mathrm{CO}$, and $\mathrm{CO}_{2}$, as specified in each test matrix. Integrated formaldehyde and ammonia samples and canister samples for speciated organics were taken at the burner or PrOx 
outlet during certain runs. Total PM was measured downstream of the burner exhaust during specific runs.

Samples for HC speciation were collected during fuel processor testing using evacuated canisters. The grab samples were collected once the system reached a given load set point, as shown in Figure 2-4. Of the grab samples collected, a majority of the canisters were analyzed for speciated HC emissions. The remainder of the canisters served as duplicates to be used in the event that results are inconclusive or the primary samples do not arrive intact.

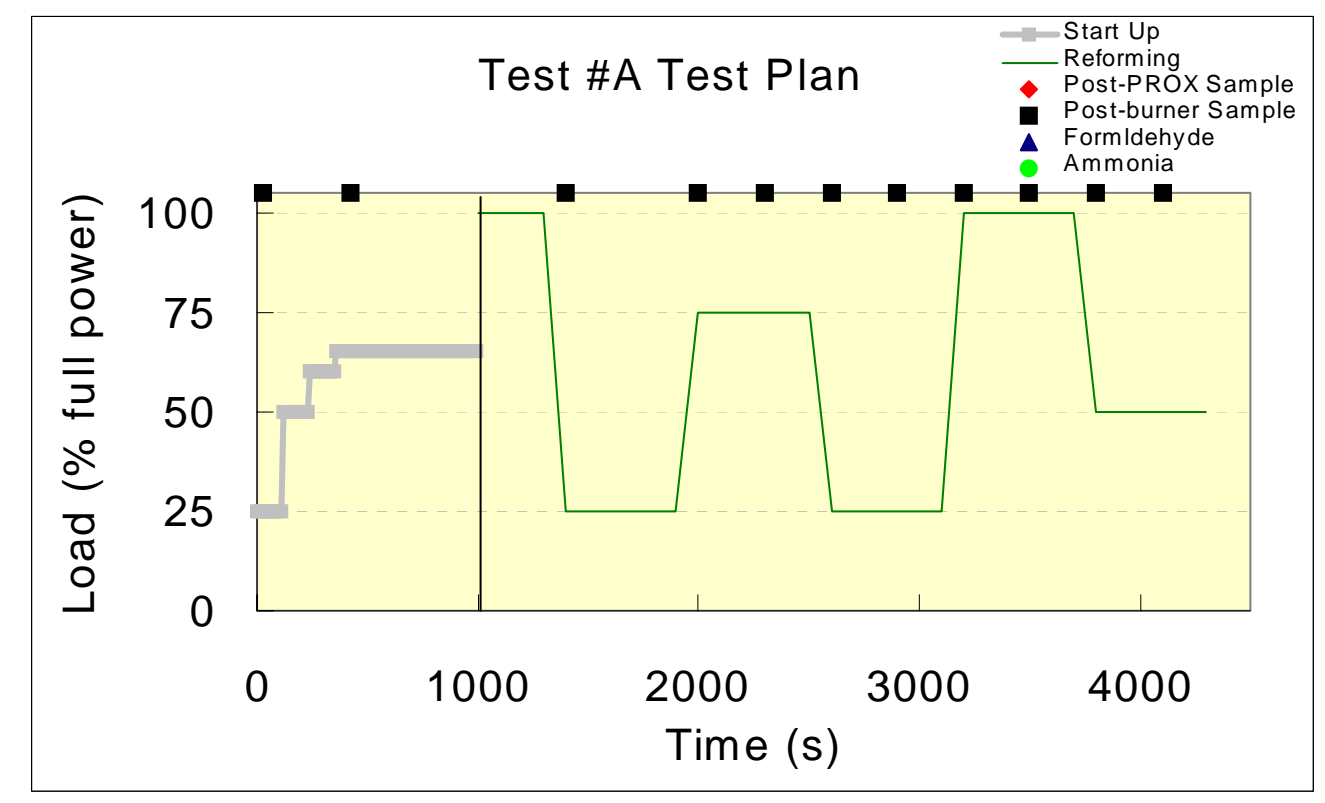

Figure 2-4. Representative Load Curve for an Emissions Sampling Run

The sampling occurred in a pre-determined sequence, with CEM sampling running continuously. Where possible, PM, formaldehyde, and ammonia sampling took place over a 30-minute period at a given load. 


\section{Emissions Testing}

Four fuel processor systems were tested for HC speciation and criteria pollutant emissions. While the test program was aimed at assessing the emissions for on board fuel processors, only developmental systems were available. The configuration of the systems is summarized in Table 3-1. Only the Nuvera ethanol reformer was integrated with a PEM fuel cell. Two other Nuvera systems produced reformate, which were burned with air. The McDermott system produced a reformate stream that was not matched to a combustor; therefore only the speciation of the reformate was measured in addition to startup combustion emissions from a gasoline burner. Continuous emission monitoring and HC speciation was performed for each of the systems as described below. The impact of the system configuration on the product streams and emission measurements is discussed for each system in the following sections.

Table 3-1. CEM and Integrated Emissions Sampling Configurations

\begin{tabular}{|l|l|l|l|}
\hline \multicolumn{1}{|c|}{$\begin{array}{l}\text { Test Stand and } \\
\text { Use of PEMFC }\end{array}$} & $\begin{array}{c}\text { Fuel } \\
\text { Processor } \\
\text { Diagram }\end{array}$ & \multicolumn{1}{|c|}{$\begin{array}{c}\text { Integrated } \\
\text { Species Tested }\end{array}$} & Integrated Sampling Media \\
\hline $\begin{array}{l}\text { Nuvera B System } \\
\text { ATR without PEMFC }\end{array}$ & Figure 3-2 & PM, speciated HC & Quartz filter, Tedlar bags \\
\hline $\begin{array}{l}\text { MTI ATR without } \\
\text { PEMFC }\end{array}$ & Figure 3-3 & $\begin{array}{l}\text { PM, speciated HC, } \\
\text { ammonia, formaldehyde }\end{array}$ & $\begin{array}{l}\text { Quartz filter, chilled impingers } \\
\text { with HCl, same with Sep Pak, } \\
\text { Summa canisters }\end{array}$ \\
\hline $\begin{array}{l}\text { Nuvera Ethanol } \\
\text { Reformer with } \\
\text { PEMFC }\end{array}$ & Figure 3-4 & $\begin{array}{l}\text { PM, speciated HC, } \\
\text { ammonia, formaldehyde, } \\
\text { alcohols }\end{array}$ & $\begin{array}{l}\text { Quartz filter, chilled impingers } \\
\text { with HCl, same with Sep Pak, } \\
\text { Summa canisters }\end{array}$ \\
\hline $\begin{array}{l}\text { Nuvera Star } \\
\text { Reformer without } \\
\text { PEMFC }\end{array}$ & Figure 3-2 & $\begin{array}{l}\text { PM, speciated HC, } \\
\text { ammonia, formaldehyde }\end{array}$ & $\begin{array}{l}\text { Quartz filter, chilled impingers } \\
\text { with HCl, same with Sep Pak, } \\
\text { Summa canisters }\end{array}$ \\
\hline
\end{tabular}

\subsection{Nuvera B System ATR}

The Nuvera B System ATR fuel processor tested in 2000 was an early prototype. The system was part of the ongoing development effort for fuel processors. ${ }^{13}$ A prototype is shown in Figure 3-1. The fuel processor operates as an ATR where steam and partial oxidation products react over a catalyst to form CO and hydrogen. The system incorporates an internal HTS and LTS reactors. A PrOx reactor removes CO to levels below 20 ppm.

13 P. S. Chintawar, B. Bowers, A. Xue, W. Mitchell, J. Zhao, M. Ruffo, D. Dattatraya, and V. Sweetland, Nuevera Fuel Cells, Inc., “Advanced High Efficiency Quick-Start Fuel Processor for Transportation Applications, DOE FY2004 Progress Report. 


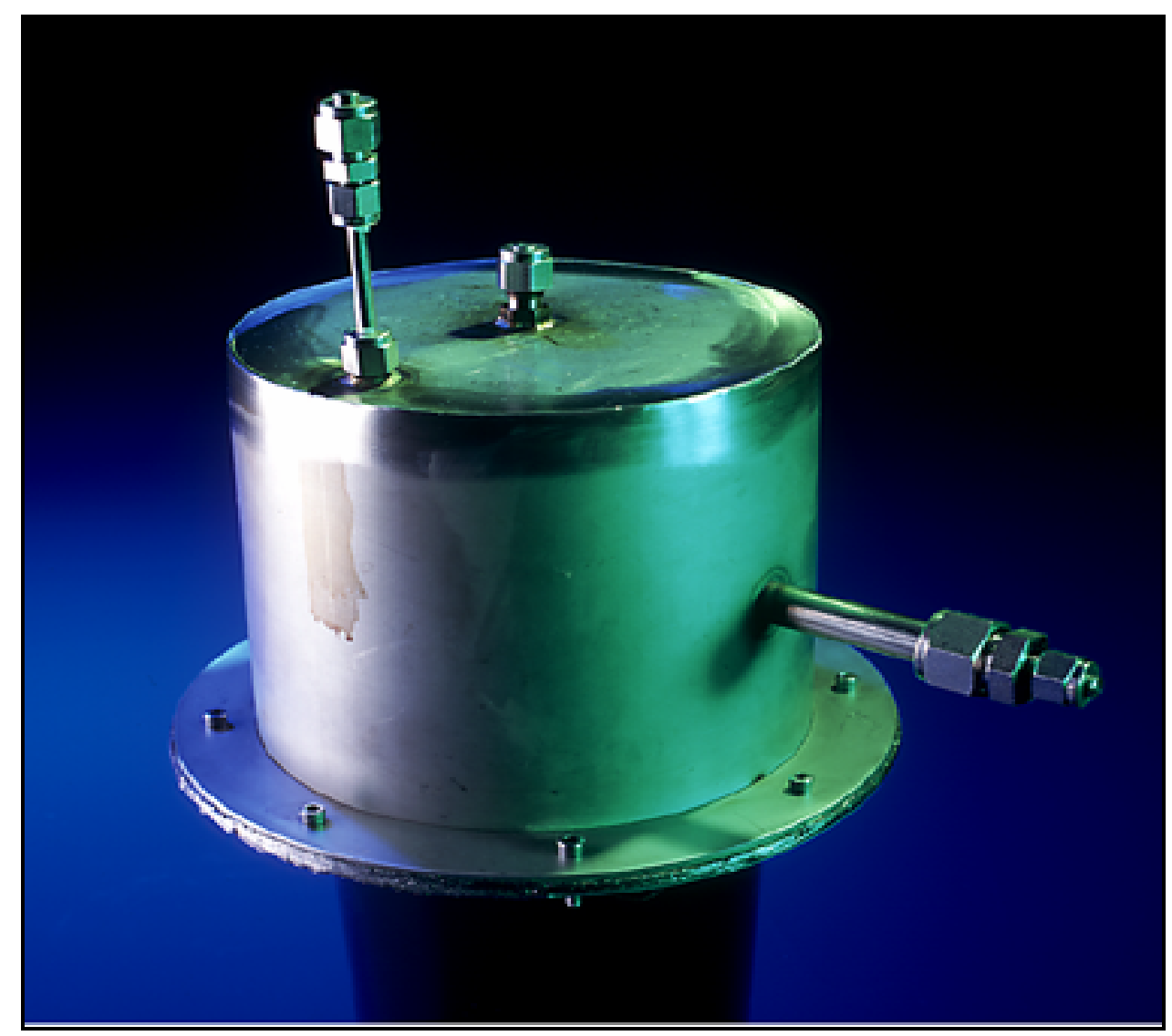

Figure 3-1. Prototype of Nuvera B Fuel Processor

The system tested produced sufficient hydrogen to power a $45 \mathrm{~kW}$ PEMFC. Nuvera has conducted extensive performance testing of the system operating on ethanol and gasoline, although emissions were not the focus and an AGB was not incorporated into the system for these prior tests. For the tests performed in this project, a catalytic AGB was installed downstream of the PrOx. A fuel cell was not available for integrating into the test system for these tests, so testing was performed without one installed. All tests were performed with gasoline fuel feed to the ATR. A block diagram of the system tested is shown in Figure 3-2. Emission sampling points for this system included post PrOx and post AGB. AGB emissions were also diverted through a filter for particulate measurement.

The AGB burned a mixture of PrOx product and air, which does not reflect the combustion reactants that would be available if fuel cell anode gas were burned. The fuel cell anode gas would be depleted of approximately 80 percent of its hydrogen. If the burner were connected to an expander, the fuel cell cathode gas would provide the source of combustion air. In this situation, the cathode air would be depleted of approximately 50 percent of its oxygen. The configuration, as tested, results in higher combustion temperatures and $\mathrm{NO}_{\mathrm{x}}$ formation than those from an integrated fuel processor/fuel cell system. The ratio of hydrocarbons to carbon products is the same for the system tested and for an integrated system. 


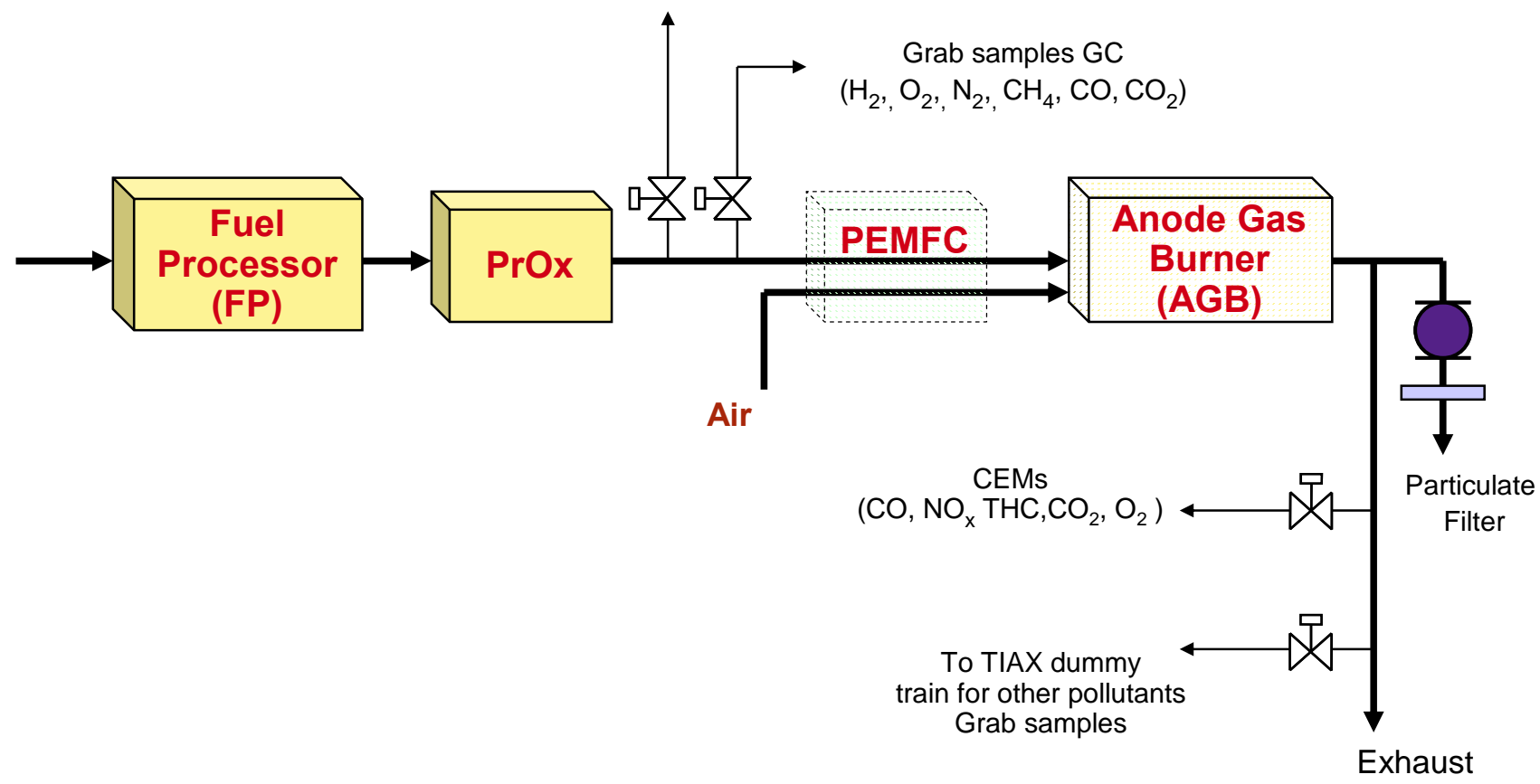

\section{Figure 3-2. Schematic of the Setup of the Nuvera B Fuel Processor Tested in 2000}

\subsubsection{Data Analysis Considerations}

TIAX used fuel flow measurements into the fuel processor (as provided by Nuvera), along with an estimate of the equivalence ratio based on the PrOx outlet emissions, to determine the corresponding total mass flow rate out of the PrOx. Similarly, TIAX used airflow measurements into the exhaust burner (as provided by Nuvera), along with an estimate of the equivalence ratio based on the exhaust burner outlet emissions, to determine the total mass flow rate out of the exhaust burner. Total mass flow was used to determine pollutant emissions on a g/second basis.

Pollutant emissions on a per unit fuel consumed basis were also calculated from the ratio of pollutant emissions to carbon based emissions $\left(\mathrm{CO}_{2}, \mathrm{CO}\right.$, methane).

\subsubsection{Startup Operation}

It should be noted that the startup procedure for this fuel processor is substantially different from a fuel processor that would be used on-board a vehicle. The fuel processor was configured in a heavy flanged pressure vessel, which required a large amount of warm up time to heat the system before operating in reforming mode.

The fuel processor warm up procedure was started every morning during the week of emission testing. The long warm up time for this fuel processor limited the amount of startup data that could be collected during the testing program. Even though the startup procedures did not represent those from a developed system, emissions data were collected with startup on gasoline fuel and reported on a ng/J basis (nanogram per Joule or gram per gigajoule). 


\subsubsection{Reformate Combustion}

The product gas from the fuel processor was burned with air in the AGB. Table 3-2 compares the combustion of the reformate compared to an integrated fuel processor/ fuel cell system. With an integrated system, the reformate steam would flow to the fuel cell first and then to the AGB. About 80 percent of the hydrogen in the reformate stream would be consumed by the fuel cell reducing the energy content of the anode gas by about 22 percent.

Table 3-2. Comparison of Combustion Characteristics for the Nuvera B Fuel Processor and an Integrated System

\begin{tabular}{|l|l|l|}
\hline \multicolumn{1}{|c|}{ Figure of Merit } & $\begin{array}{c}\text { Test System compared to } \\
\text { Integrated FP/FC }\end{array}$ & \multicolumn{1}{c|}{ Comments } \\
\hline Peak Hydrogen Output & Same $(50 \mathrm{kWe})$ & \\
\hline PrOx & Same & $\begin{array}{l}\text { Higher heat release rate results in higher } \\
\text { combustor temperatures. NO } \text { emissions } \\
\text { are higher. Combustion efficiency of } \\
\text { hydrocarbons could also be affected }\end{array}$ \\
\hline $\begin{array}{l}\text { Hydrogen \& Heat } \\
\text { Release per mole C }\end{array}$ & $5 \times$ FP/FC system & $\begin{array}{l}\text { Trace HC space velocity over catalyst is } \\
\text { similar to FPFC system. }\end{array}$ \\
\hline HC per mole of C & Same & \multicolumn{2}{|c|}{. } \\
\hline
\end{tabular}

\subsection{MTI ATR}

The MTI ATR-based fuel processor had a similar setup schematic to the Nuvera B system, except it had an external high- and low-temperature shift reactor. ${ }^{14}$ The setup schematic for the MTI fuel processor, as tested in August 2002, is shown in Figure 3-3. A fuel cell was not available for integrating into the system for these tests, so testing was performed without one installed. All tests were performed with gasoline fuel fed to the ATR.

Although the MTI ATR was designed for use with a $50 \mathrm{kWe}$ fuel cell system, the PrOx in use during the emissions testing was only designed for use with a $10 \mathrm{kWe}$ system. Thus, at the time of the emission test, the apparatus could only accommodate a maximum reformer operation of 10 to $12 \mathrm{kWe}$ equivalent hydrogen output, or 20 percent of the rated output. Also, the ATR was unable to operate consistently below 6 to $8 \mathrm{kWe}$ equivalent, thus limiting the range of output that could be tested.

During testing, the PrOx outlet gas stream was not passed through the AGB, thus there was no opportunity to measure the emissions from reformate combustion. However, the AGB was operated on gasoline to generate steam for the reformer during startup and as needed to maintain reformer temperature during emissions testing. This operating mode bounds the high end of emissions that would be observed during the startup of an on-board reformer system, and thus was useful to observe.

14 Milind V. Kantak and John R. Budge, McDermott Technology Inc., "Catalytic Partial Oxidation (CPOX) Reformer Development,” Fuel Cell Seminar, 2003. 


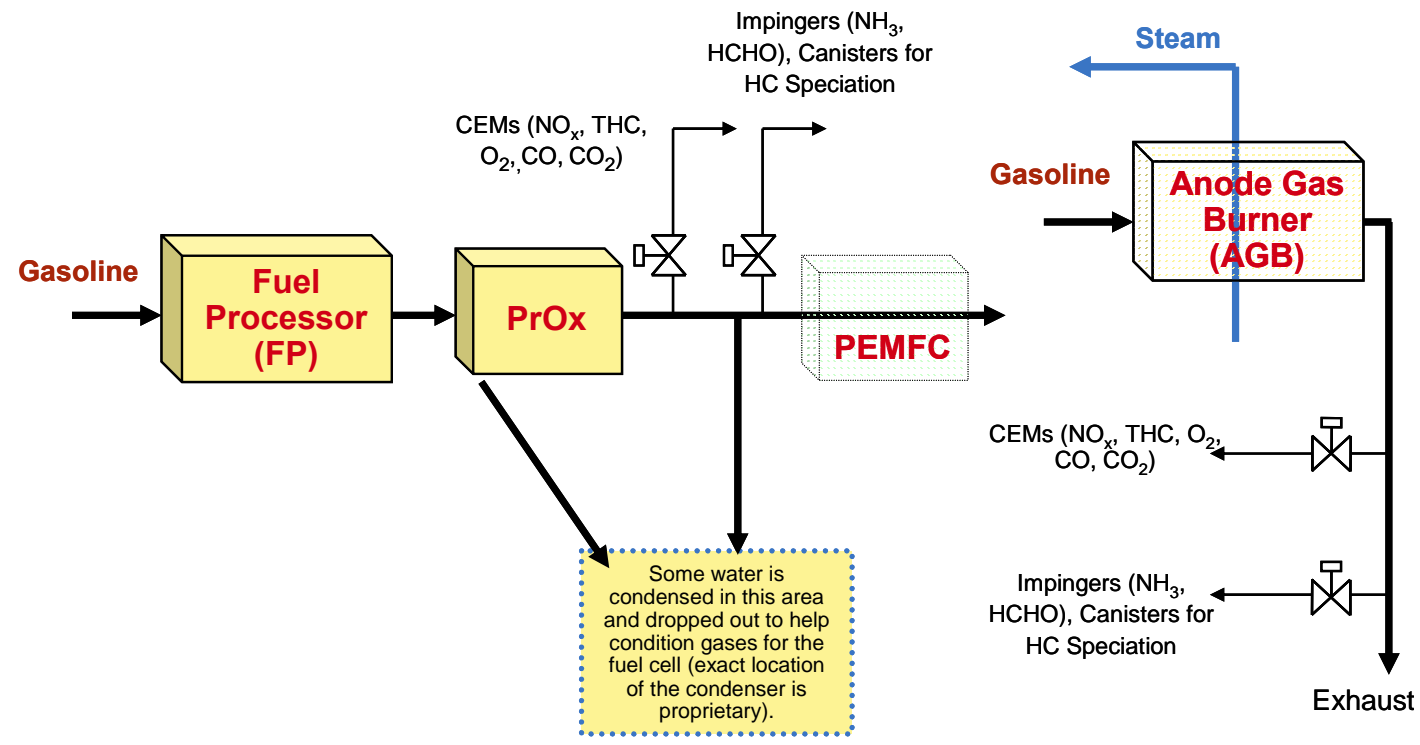

Figure 3-3. Setup Schematic of the MTI ATR Fuel Processor System Tested in 2002

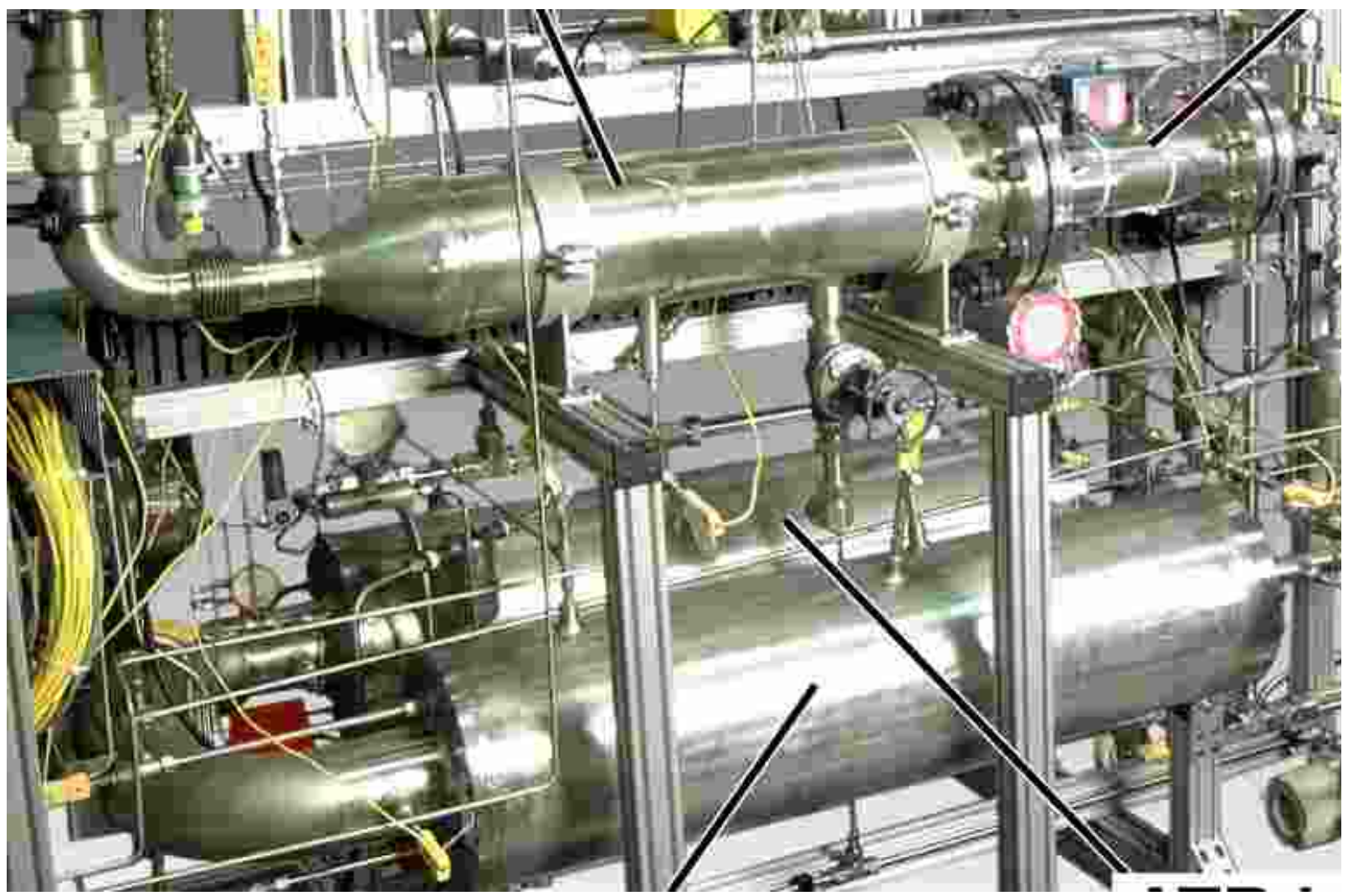

Figure 3-4. Reformer and AGB for MTI ATR Fuel Processor System Tested 


\subsubsection{Data Analysis Considerations}

The MTI fuel processor system was not configured to burn the PrOx product. The data from this test provided information on gasoline burner operation, which could represent start up emissions. The PrOx product speciation provides insight into the mix of non-methane hydrocarbons to total hydrocarbons.

\subsubsection{Startup Operation}

Startup for the MTI system was achieved by flowing steam through the reformer system. A gasoline burner was fired to provide the heat to generate steam for startup and system operation. Like with the Nuvera B fuel processor test, the startup procedure for this fuel processor was substantially different from a fuel processor that would be used on-board a vehicle. The fuel processor required a larger warm up time to heat the system to a full reforming mode than it would take to warm up a much smaller integrated system.

The fuel processor warm up procedure was started every morning during the week of emission testing, and was initiated by the MTI staff several hours before the emissions testing was to begin, in order to ensure stable operation when the testing runs were scheduled to start. Even though the startup procedures did not represent those from a developed system, emissions data collected from the gasoline burner were compared to the startup emissions from other tests and reported on a $\mathrm{ng} / \mathrm{J}$ basis.

\subsubsection{Reformate Combustion}

With an integrated fuel processor/ fuel cell system, the reformate steam would flow to the fuel cell first and then to the AGB. About 80 percent of the hydrogen in the reformate stream would be consumed by the fuel cell reducing the energy content of the anode gas by about 22 percent.

As indicated above, the system was operated at no more than $12 \mathrm{kWe}$ equivalent output, due to the load capacity of the PrOx in use. The reformate was passed through the PrOx, and then to an exhaust combustor that was inaccessible and therefore not monitored for emissions. Table 3-3 compares the known results from this test with a system operating with an integrated fuel processor/fuel cell system.

Table 3-3. Comparison of Combustion Characteristics for the MTI Fuel Processor and an Integrated System

\begin{tabular}{|l|l|l|}
\hline \multicolumn{1}{|c|}{ Figure of Merit } & $\begin{array}{c}\text { Test System compared to } \\
\text { Integrated FPFC }\end{array}$ & \multicolumn{1}{c|}{ Comments } \\
\hline \hline Peak Hydrogen Output & $\begin{array}{l}0.2 \times \text { FPFC system } \\
(10 \mathrm{kWe})\end{array}$ & $\begin{array}{l}\text { Developmental PrOx was sized for } \\
10 \mathrm{kWe}\end{array}$ \\
\hline PrOx & Same & $\begin{array}{l}\text { Fuel cell was not available. Combusting } \\
\text { hydrogen rich reformate was not feasible } \\
\text { with available hardware. }\end{array}$ \\
\hline $\begin{array}{l}\text { Hydrogen \& Heat } \\
\text { Release per mole C }\end{array}$ & Not combusted & \\
\hline HC per mole of C & Same & \\
\hline
\end{tabular}




\subsection{Nuvera Ethanol Reformer}

The Nuvera Ethanol reformer test was performed on an integrated reformer and fuel cell system, as indicated in Figure 3-5. Nuvera integrated an ethanol ATR with a PEM fuel cell in a test program with Caterpillar. ${ }^{15}$ The fuel cell power system was designed for stationary power generation and not for vehicle applications. However, this is the only ATR system coupled with a PEM fuel cell that was available during the period of the test program. Other ATR/PEMFC systems had been built and were being tested, but the timing and test program constraints of these projects did not coincide with the scheduling for this project.

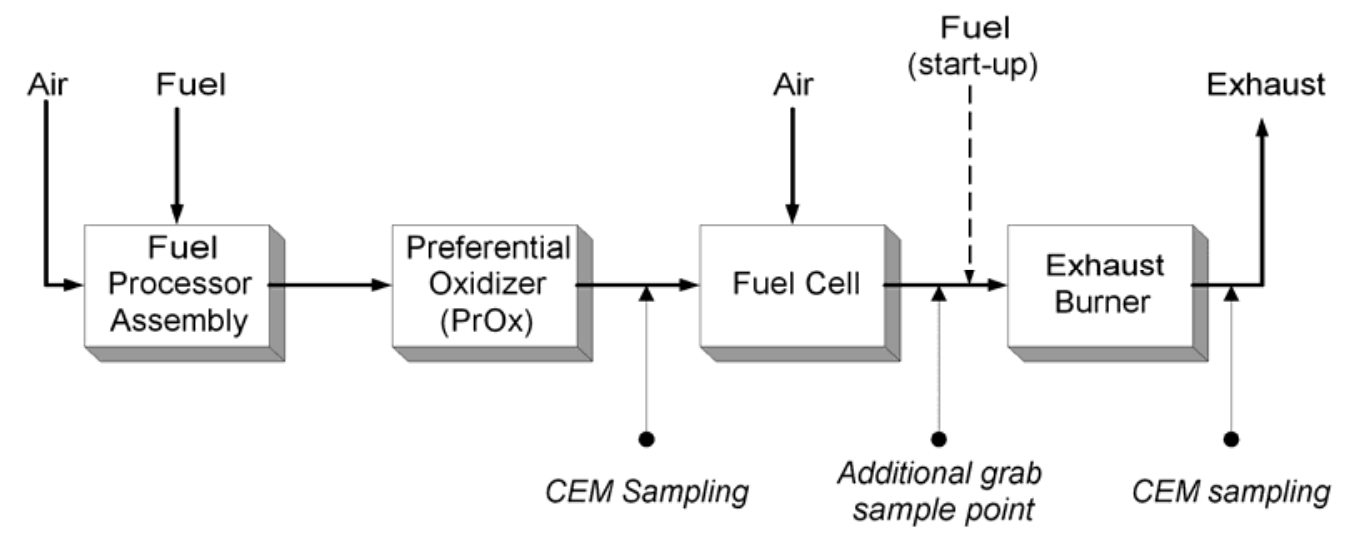

Figure 3-5. Set-up Schematic for the Nuvera Ethanol Fuel Processor Tested in 2003

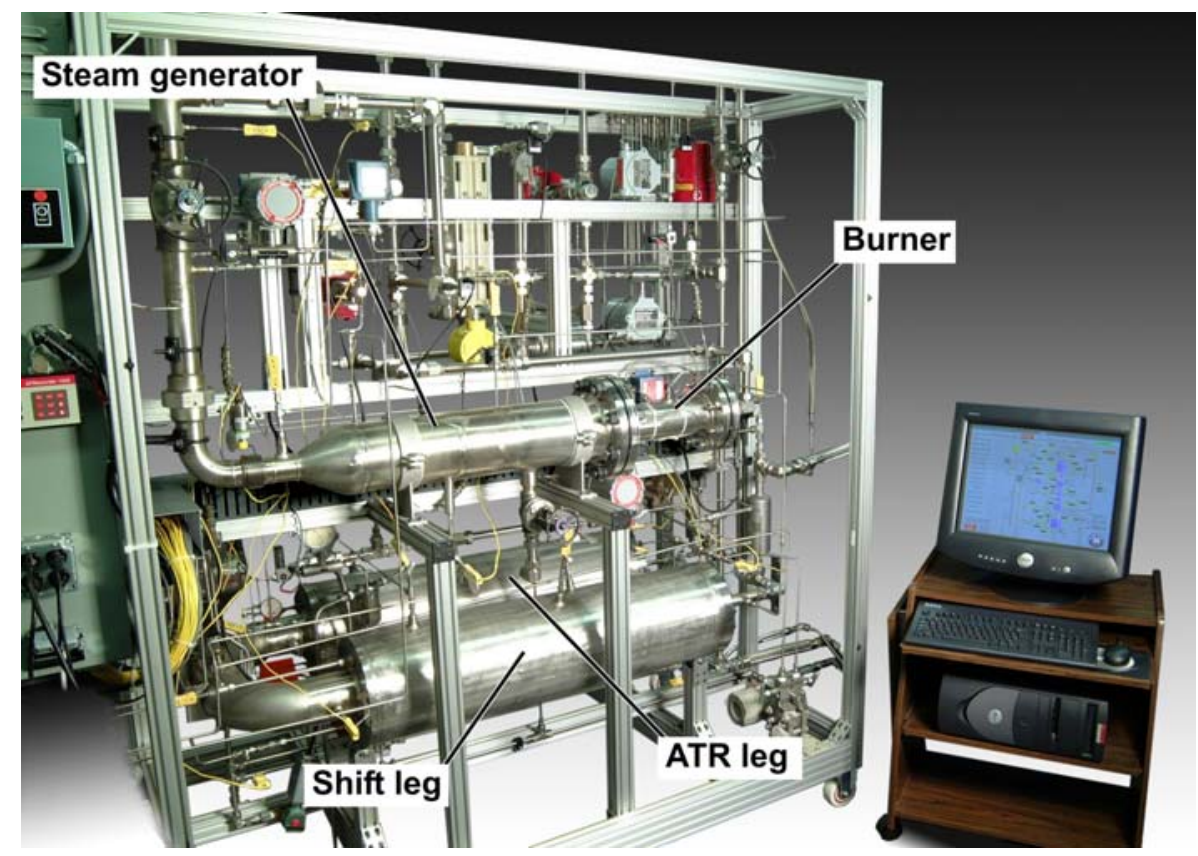

Figure 3-6. Nuvera Ethanol Fuel Processor Integrated with Caterpillar Power Module

15 Ahmed Amrani and Thomas Richards, Caterpillar Inc., "Proton Exchange Membrane Fuel Cell Power System on Ethanol,” DOE FY 2003 Progress Report. 


\subsubsection{Data Analysis Considerations}

Similar to the Nuvera B fuel processor tests, emissions were sampled at the PrOx and after the AGB. In the case of the system shown in Figure 3-5, hydrogen is consumed by the fuel cell. The hydrogen depleted anode gas is burned in the AGB.

\subsubsection{Startup Operation}

The Nuvera ethanol reformer emissions tests were based on a reformer system operating as indicated in Figure 3-2. A representative fuel processor load demand curve for testing this system is shown in Appendix A. This profile simulates the case where the fueling rate to the fuel processor is dictated by the power demand on the fuel cell, except under operating conditions in which the stack power demand is below the minimum power output capacity of the fuel processor. For example, if the fuel processor is capable of producing the fuel equivalent of 25 to 100 percent full load, it will only follow the fuel cell stack power demand when the power demand exceeds the fuel equivalent of 25 percent full load.

The product gas from the fuel processor was first fed to the PEM fuel cell and then burned with air in the AGB. Table 3-4 compares the combustion of the reformate compared to an integrated fuel processor/ fuel cell system.

\section{Table 3-4. Comparison of Combustion Characteristics for the Nuvera Fuel Processor and an Integrated System}

\begin{tabular}{|l|l|l|}
\hline \multicolumn{1}{|c|}{ Figure of Merit } & $\begin{array}{c}\text { Test System compared to } \\
\text { Integrated FPFC }\end{array}$ & \multicolumn{1}{c|}{ Comments } \\
\hline \hline PEM Fuel Cell & Yes $(10 \mathrm{kWe})$ & $\begin{array}{l}\text { Fuel cell consumes hydrogen in } \\
\text { reformate stream }\end{array}$ \\
\hline PrOx & Yes $(10 \mathrm{kWe})$ & $\begin{array}{l}\text { Developmental system. Peak reformer } \\
\text { output was 50 kWe }\end{array}$ \\
\hline Peak Hydrogen Output & Same $(10 \mathrm{~kW})$ & \\
\hline $\begin{array}{l}\text { Hydrogen \& Heat } \\
\text { Release per mole C }\end{array}$ & Same & \\
\hline HC per mole of C & Same & \\
\hline
\end{tabular}

\subsection{Nuvera Star Reformer}

The Nuvera Star fuel processor represents their latest development in the field of on-board fuel processing. ${ }^{16}$ A system that produces reformate for a $50 \mathrm{kWe}$ fuel cell was tested. Testing program and configuration of the test set up were the same as that for the earlier test with the B system described in Section 3.1.

16 P. S. Chintawar, B. Bowers, A. Xue, W. Mitchell, J. Zhao, M. Ruffo, D. Dattatraya, and V. Sweetland, Nuevera Fuel Cells, Inc., “Advanced High Efficiency Quick-Start Fuel Processor for Transportation Applications, DOE FY2004 Progress Report. 


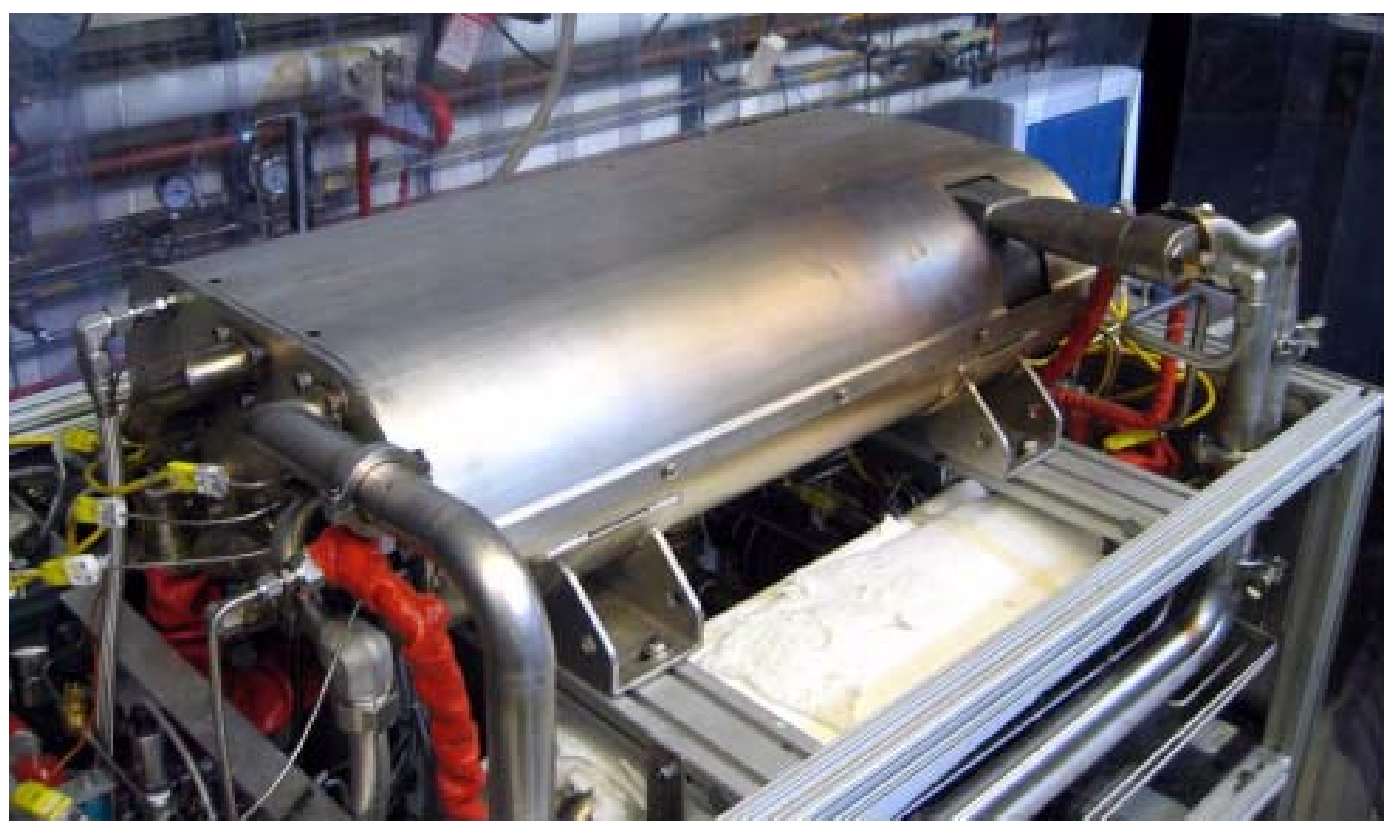

Figure 3-7. STAR Fuel Processor on Test Stand

\subsubsection{Reformate Combustion}

The test system for the Nuvera Star fuel processor was configured with a $50 \mathrm{kWe}$ reformer. The product gas from the fuel processor was burned with air in the AGB. Table 3-5 compares the combustion of the reformate compared to an integrated fuel processor/ fuel cell system.

Table 3-5. Comparison of Combustion Characteristics for the Nuvera Star Fuel Processor and an Integrated System

\begin{tabular}{|l|l|l|}
\hline \multicolumn{1}{|c|}{ Figure of Merit } & $\begin{array}{c}\text { Test System compared to } \\
\text { Integrated FPFC }\end{array}$ & \multicolumn{1}{c|}{ Comments } \\
\hline PEM Fuel Cell & None & $\begin{array}{l}\text { Fuel cell consumes hydrogen in } \\
\text { reformate stream }\end{array}$ \\
\hline PrOx & Yes $(10 \mathrm{kWe})$ & $\begin{array}{l}\text { Developmental system. Peak reformer } \\
\text { output was 50 kWe }\end{array}$ \\
\hline Peak Hydrogen Output & $0.2 \times$ FPPC system & \\
\hline $\begin{array}{l}\text { Hydrogen \& Heat } \\
\text { Release per mole C }\end{array}$ & Same & \\
\hline HC per mole of C & Same & \\
\hline
\end{tabular}




\subsection{Emission Testing Results}

THC, $\mathrm{CO}$, and $\mathrm{NO}_{\mathrm{x}}$ emissions were measured on a continuous basis during startup and reforming operation. Both startup and AGB combustion emissions were sampled. The emissions were plotted versus time for various test runs. The reformer output, indicated as a fraction of full load was also plotted. While these test results do not represent an integrated vehicle system, the trends are useful in assessing the potential emissions from ATR/PEMFC systems. CEM data results are presented and discussed for each of the four systems tested in the following sections.

\subsubsection{Nuvera B ATR CEM Results}

The burner outlet results varied between the reformer systems tested. For the Nuvera 2000 CEM data for the test run are superimposed onto the process load data in Figure 3-8. The Nuvera CEM system measured THC at the AGB exit, and $\mathrm{CO}$ and $\mathrm{NO}_{\mathrm{x}}$ concentrations at the PrOx exit for most of the test run. The Nuvera $\mathrm{CO}$ and $\mathrm{NO}_{\mathrm{x}}$ analyzers were switched to monitor AGB exit gas late in the period of rated load $(45 \mathrm{~kW})$ operation, and continued monitoring at this location through the gradual decrease in load to $20 \mathrm{~kW}$, and the brief period of operation at $20 \mathrm{~kW}$. The

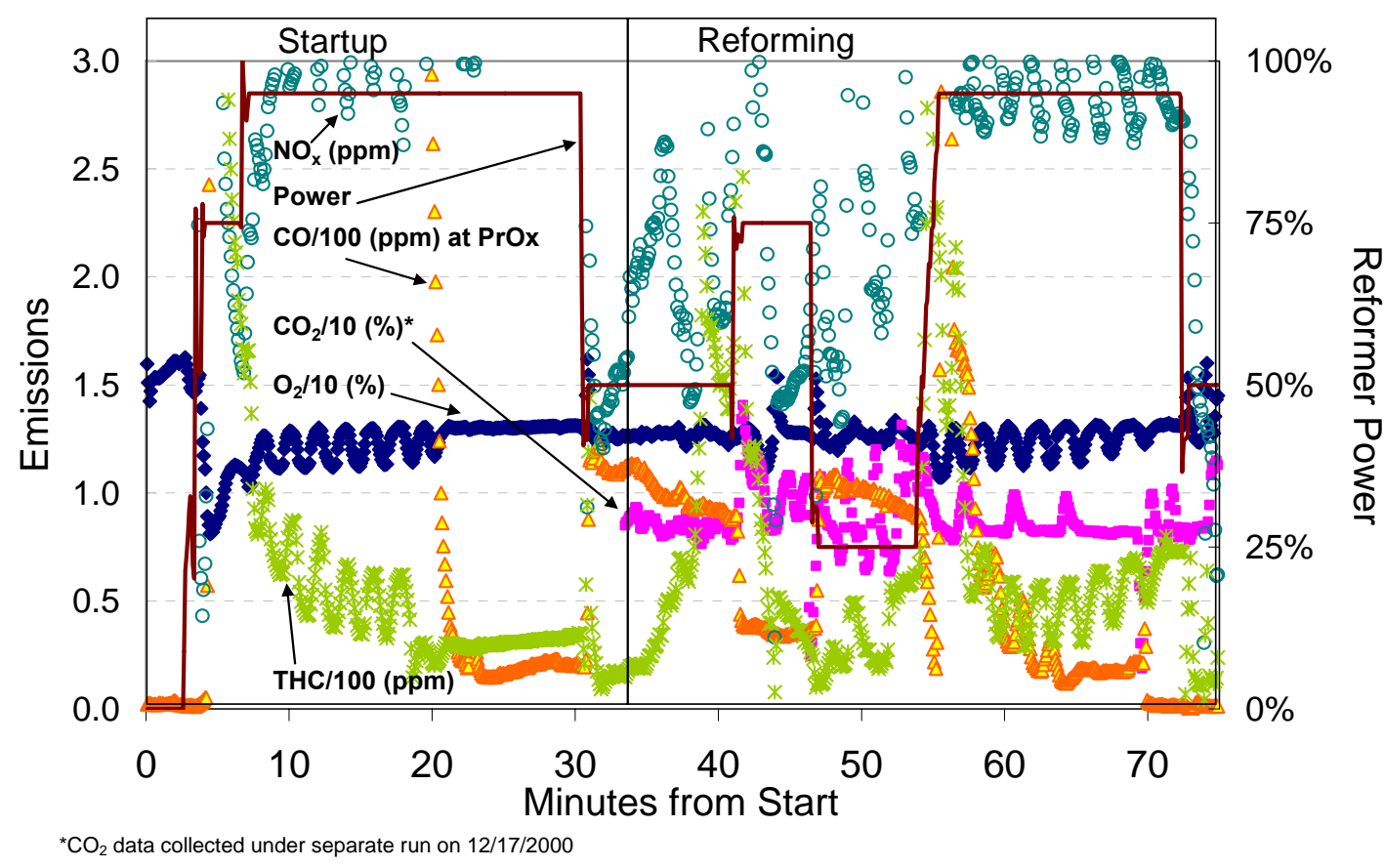

Figure 3-8. CEM Results at Burner Outlet, Nuvera ATR, October 11, 2000 
$\mathrm{NO}_{\mathrm{x}}$ measurements for the PrOx exit are not shown in Figure 3-8 as $\mathrm{NO}_{\mathrm{x}}$ concentrations were uniformly zero at this location. The THC concentration data shown in the figure are in terms of ppm as carbon.

The data in Figure 3-8 show that, as fuel flow to the AGB was initiated, THC levels rapidly increased to over 1,000 ppm. In fact they exceeded the upper limit of the monitor of 2,000 ppm. However, shortly after fuel flow to the TGC was terminated and fuel flow to the FPA started, THC levels rapidly decreased to below 100 ppm, settling to about 35 ppm late in the FPA warmup period. THC levels further decreased to about $15 \mathrm{ppm}$ after the brief introduction of fuel to the AGB at the start of reforming operation, then increased to between 100 and 200 ppm near the end of the period of steady operation of the FPA at $20 \mathrm{~kW}$. Another spike in AGB THC emissions accompanied the rapid increase in FPA load to $35 \mathrm{~kW}$, followed by a gradual decrease to about $30 \mathrm{ppm}$ late in the period of steady operation at $35 \mathrm{~kW}$. Emissions were essentially unchanged with the rapid decrease in FPA load to $15 \mathrm{~kW}$, but, as was the case during steady operation at $20 \mathrm{~kW}$ load, showed a gradual increase from 15 to 55 ppm over the period of steady operation at $15 \mathrm{~kW}$ load. AGB THC exit gas concentrations again spiked with the gradual increase in FPA load to $45 \mathrm{~kW}$, before declining to between 50 and $70 \mathrm{ppm}$ as load was held steady at $45 \mathrm{~kW}$. Again, no change in THC emissions accompanied the load decrease to $20 \mathrm{~kW}$, with levels declining to the range observed in the early part of the previous $20 \mathrm{~kW}$ load portion of the run.

The PrOx exit CO concentration data in Figure 3-8 show that CO levels spiked to the monitor's upper measurement limit of 1,000 ppm shortly after fuel flow to the FPA to warm it up was initiated. However, about halfway into the warm-up period, PrOx exit CO levels sharply declined to about $20 \mathrm{ppm}$, and remained steady until reforming operation was initiated. PrOx exit CO levels were steady at about $100 \mathrm{ppm}$ at 20 and $15 \mathrm{~kW}$ FPA load and $35 \mathrm{ppm}$ at $35 \mathrm{~kW}$ FPA load. No abrupt transient accompanied the rapid load changes between these loads, levels appeared to quickly move to new steady operation conditions. A spike in PrOx exit CO accompanied the gradual load increase from 15 to $45 \mathrm{~kW}$ load, before declining to a steady operating condition of $20 \mathrm{ppm}$ at rated load.

The process load data for the test run are superimposed onto the TIAX CEM data in Figure 3-8 The TIAX CEM system measured $\mathrm{O}_{2}, \mathrm{NO}_{\mathrm{x}}$ and THC concentrations at the AGB exit with the THC in terms of ppm as carbon. The AGB exit $\mathrm{O}_{2}$ data in Figure 3-8 show that levels were 15 to 16 percent during the period of AGB warm-up with no fuel flow to the FPA. Once FPA warmup started and AGB fuel flow was stopped, AGB exit $\mathrm{O}_{2}$ cycled between 11.5 and 13 percent, before settling out at a steady 13 percent late in the FPA warm-up period. The THC emission cycles seen during this period of operation followed the $\mathrm{O}_{2}$ cycles, and THC emissions settled to nominally steady as the $\mathrm{O}_{2}$ level steadied. These THC concentration cycles were likely the result gas dilution. The cyclic $\mathrm{O}_{2}$ behavior reflects changes in the air feedrate to the AGB. Thus, increasing the air feedrate to the AGB results in increased measured $\mathrm{O}_{2}$ levels, and corresponding decreased THC and $\mathrm{NO}_{x}$ concentrations due to increased dilution. AGB exit $\mathrm{O}_{2}$ remained at nominally 12.8 percent over the periods of steady reforming operation at 20,35 , and $15 \mathrm{~kW}$, including the changes from load to load. At $45 \mathrm{~kW}$ FPA load, AGB exit $\mathrm{O}_{2}$ returned to cyclic behavior, varying from about 11 to 13 percent. Again, AGB THC emissions cycled in tandem with the exit $\mathrm{O}_{2}$ concentration. 
The $\mathrm{NO}_{\mathrm{x}}$ data in Figure 2-8 show that $\mathrm{NO}_{\mathrm{x}}$ emissions rapidly increased to above the instrument's upper limit of 5 ppm when warm-up fuel to the AGB was started at the initiation of the test run. These decreased to a steady level of 3 ppm after fuel flow to the AGB was terminated and the FPA warm-up period proceeded. $\mathrm{NO}_{\mathrm{x}}$ emissions decreased to the 1.5 to $2.5 \mathrm{ppm}$ range during the period of steady reforming operation at $20 \mathrm{~kW}$ FPA load, although a spike to 5 ppm occurred late in this period. Another spike in $\mathrm{NO}_{\mathrm{x}}$ to $5 \mathrm{ppm}$ occurred with the rapid increase in FPA load to $35 \mathrm{~kW}$, followed by a steady decline to about $1 \mathrm{ppm}$ as FPA load remained at this level. $\mathrm{NO}_{\mathrm{x}}$ emissions cycled between 2 and 5 ppm during the period of steady operation at $15 \mathrm{~kW}$ FPA load, though remained relatively steady at about $3 \mathrm{ppm}$ during the period of rated FPA load at $45 \mathrm{~kW}$. A steady decline in $\mathrm{NO}_{\mathrm{x}}$ emissions to below $1 \mathrm{ppm}$ accompanied the load change to $20 \mathrm{~kW}$ late in the test run, where they were as the test run concluded. The cyclic behavior of the AGB exit THC concentrations, varying with the cyclic $\mathrm{O}_{2}$ levels, is also seen in the $\mathrm{NO}_{\mathrm{x}}$ data during the early part of the FPA warm-up period and the period of rated load operation late in the test run, again likely the result of dilution.

\subsubsection{MTI Gasoline Burner CEM Results}

Emissions were monitored on a continuous basis for the gasoline burner on MTI fuel processor. The results are shown in Figures 3-9 and 3-10. The MTI burner operates on gasoline to preheat fuel for the ATR. The burner was not sized to operate of reformate from the ATR. The gasoline operating mode would reflect the emissions during startup. The emission result in Figure 3-9 show the $\mathrm{NO}_{\mathrm{x}}$ and $\mathrm{CO}$ varying steadily during the test. $\mathrm{CO}$ declines as $\mathrm{NO}_{\mathrm{x}}$ increased as the burner warmed up. Again, these results represent the burner operating on gasoline, which provides an estimate of the emissions during startup.

\subsubsection{Nuvera Ethanol ATR/PEMFC Anode Gas Burner CEM Results}

Emissions were monitored on a continuous basis from the anode gas burner exhaust of the Nuvera ethanol ATR/PEMFC system. The results are shown in Figures 3-11 and 3-12. Emissions reflected the hydrogen depleted anode waste gas combusted by the AGB. $\mathrm{NO}_{\mathrm{x}}$ emissions varied from undetectable to less than $0.5 \mathrm{ppm}$. CO emissions reflected the low levels of CO entering the PEMFC and were also below 10 ppm. THC emissions were initially high during startup and dropped to around $100 \mathrm{ppm}$ during fuel cell operation. The composition of these emissions is presented in Appendix A. They contained a mixture of methane and ethane. The ethane component is included in the NMOG measurement. Emissions during the second series of tests in Figure 3-12 were steadier than those from the previous day in Figure 3-11.

\subsubsection{Nuvera Gasoline Star ATR Tail Gas Burner CEM Results}

Emissions were monitored on a continuous basis from the anode gas burner exhaust of the Nuvera gasoline Star ATR system. The results are shown in Figures 3-13 and 3-14. These emission results are representative of the combustion of reformate in air rather than hydrogen depleted anode gas. Combustion temperatures are higher than those achieved with hydrogen depleted gas. Nonetheless, $\mathrm{NO}_{\mathrm{x}}$ emissions are still in the 1 to $2 \mathrm{ppm}$ range. $\mathrm{CO}, \mathrm{NO}_{\mathrm{x}}$, and THC emissions depend upon the PrOx composition shown in the following section. 


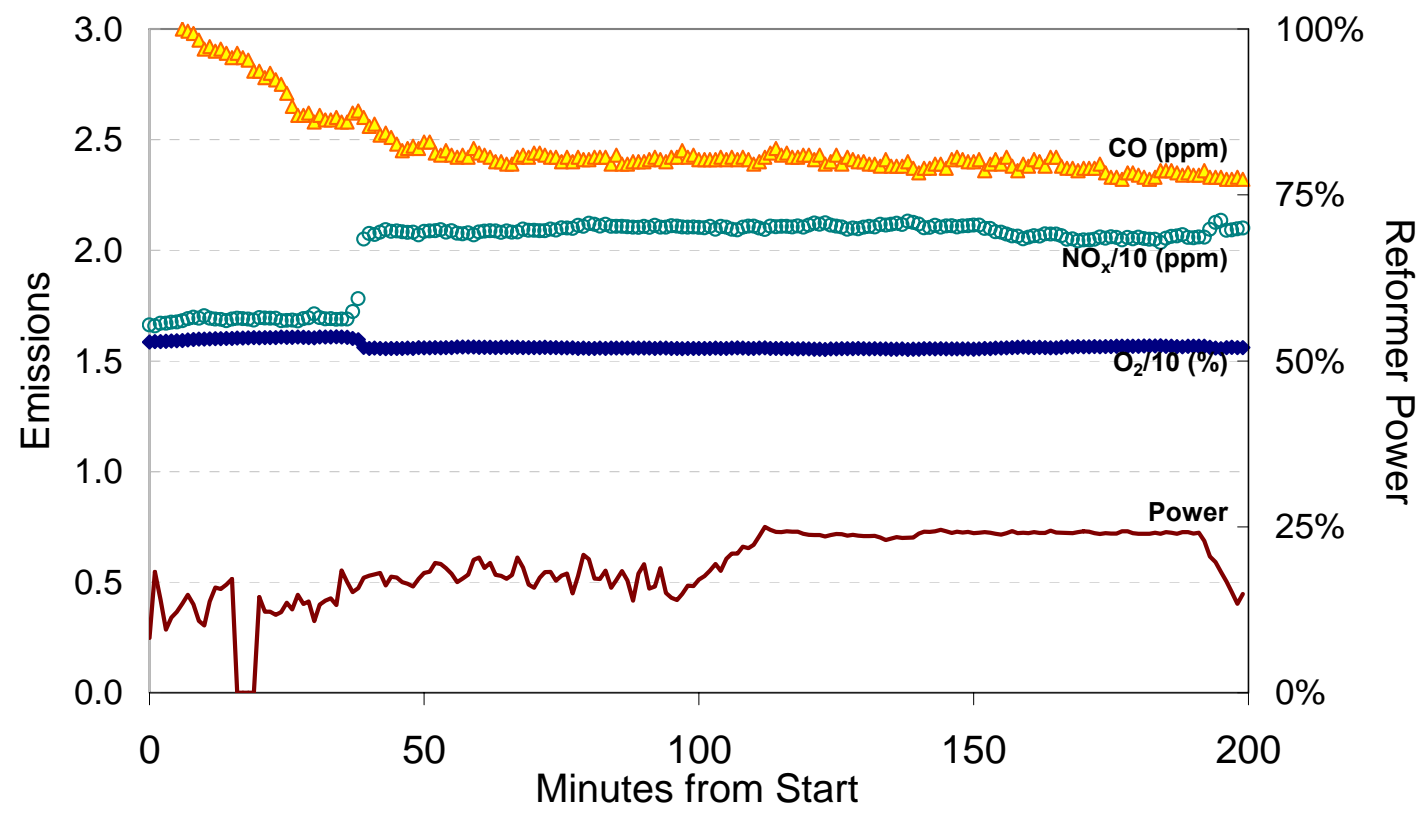

Figure 3-9. CEM Results at Gasoline Burner Outlet (RunB), MTI Gasoline Burner, August 6, 2002

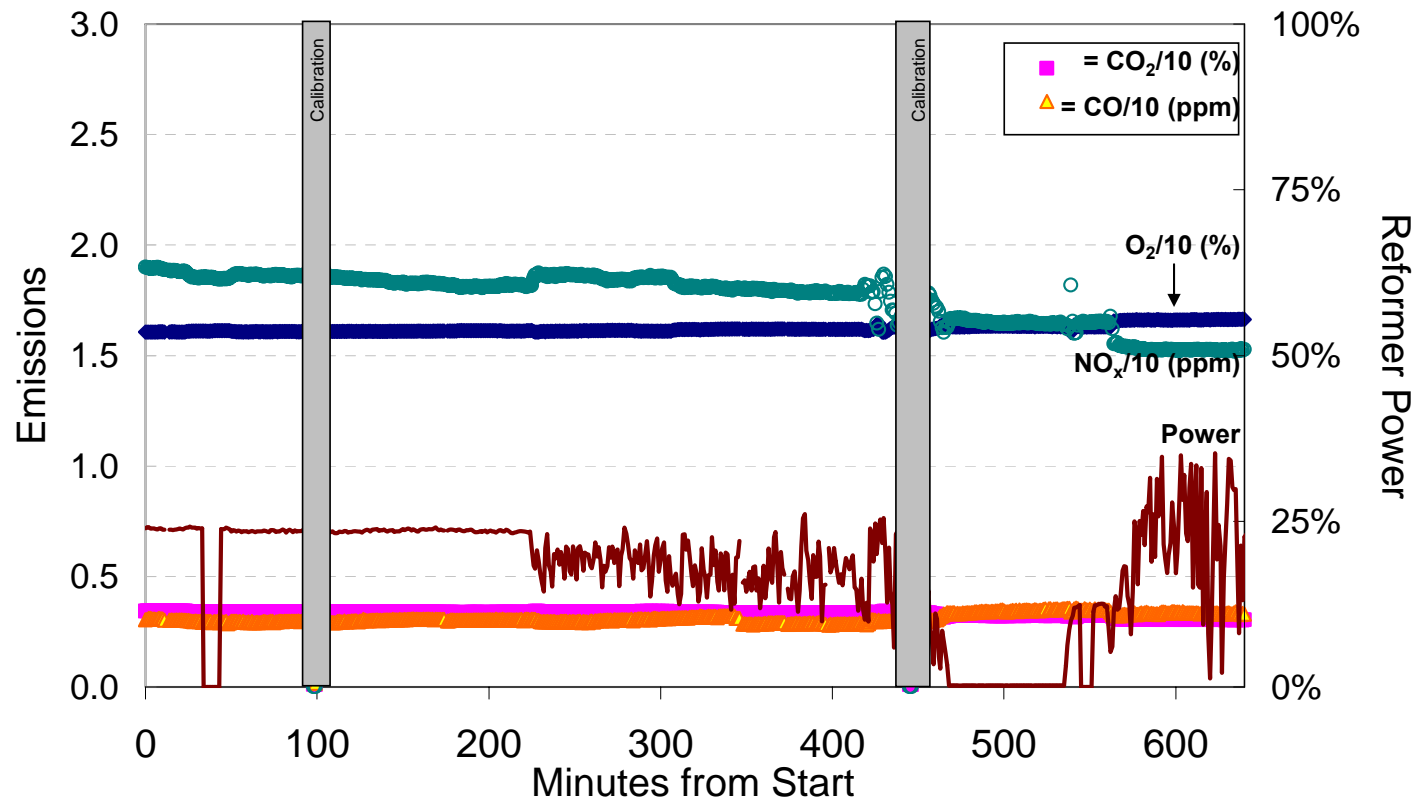

Figure 3-10. CEM Results at Gasoline Burner Outlet (RunD), MTI Gasoline Burner, August 7, 2002 


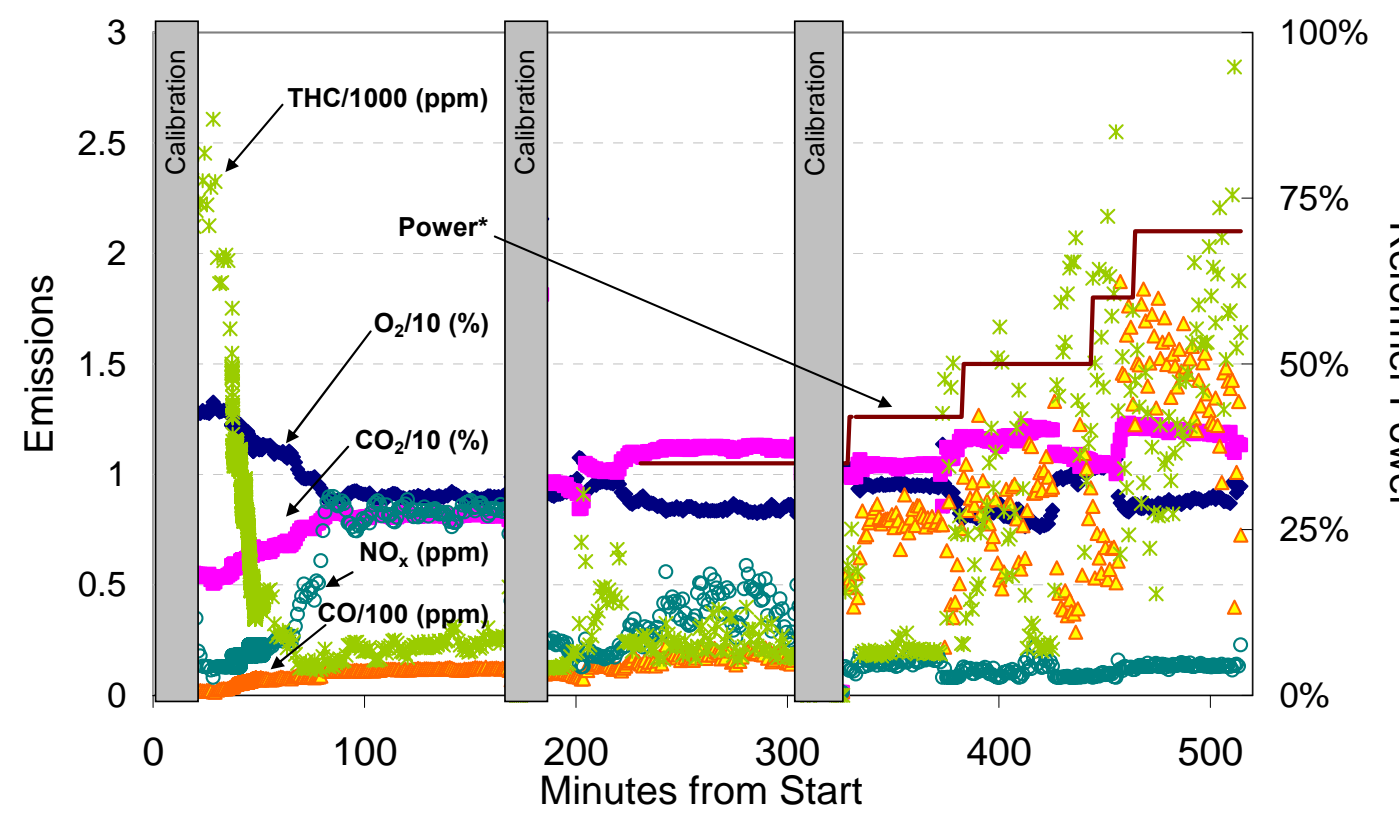

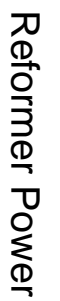

*Running at "idle" until 230 minutes from start

Figure 3-11. CEM Results at Burner Outlet, Nuvera Ethanol ATR PEMFC, February 26, 2003

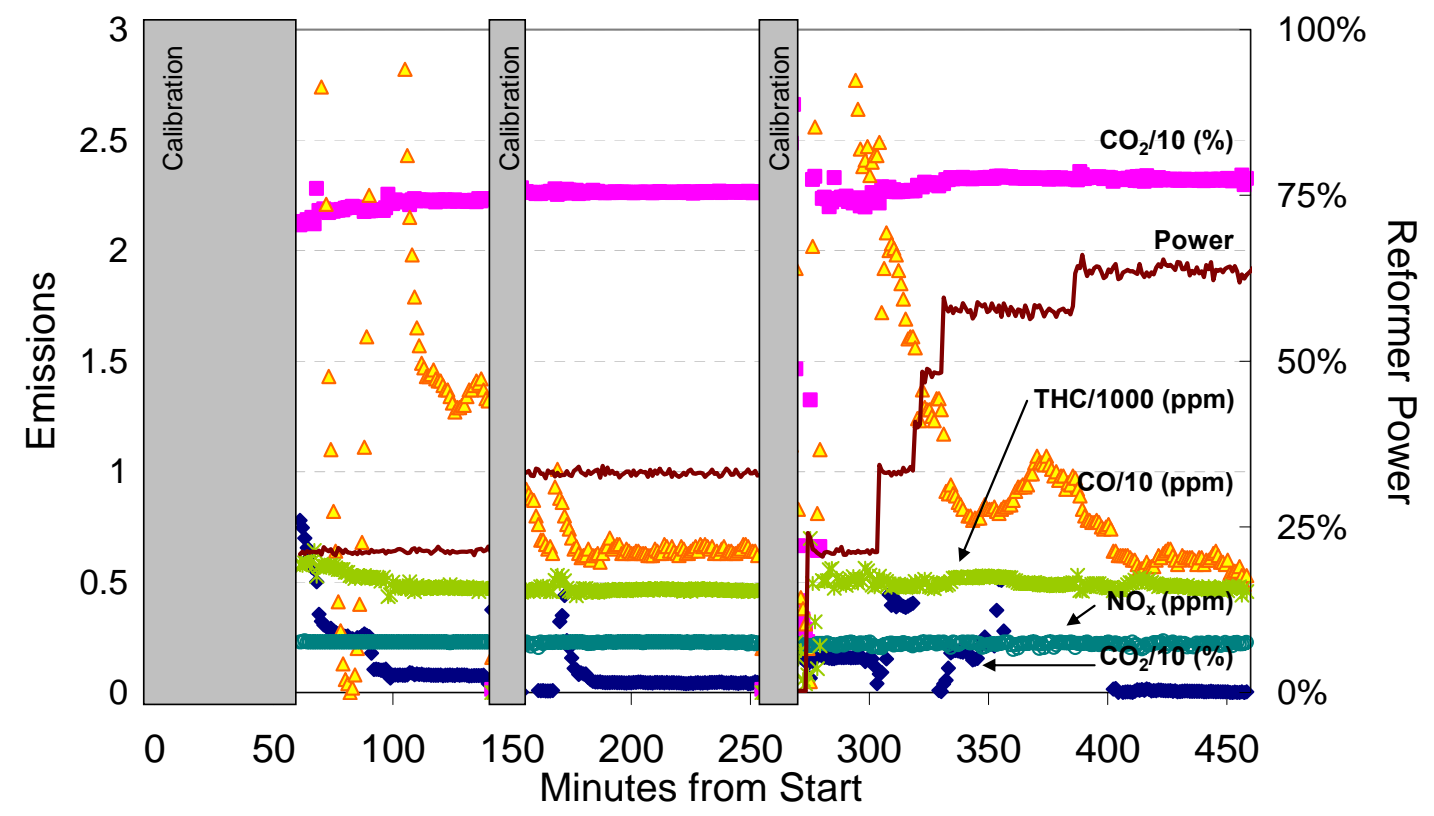

Figure 3-12. CEM Results at Burner Outlet, Nuvera Ethanol ATR PEMFC, February 27, 2003 


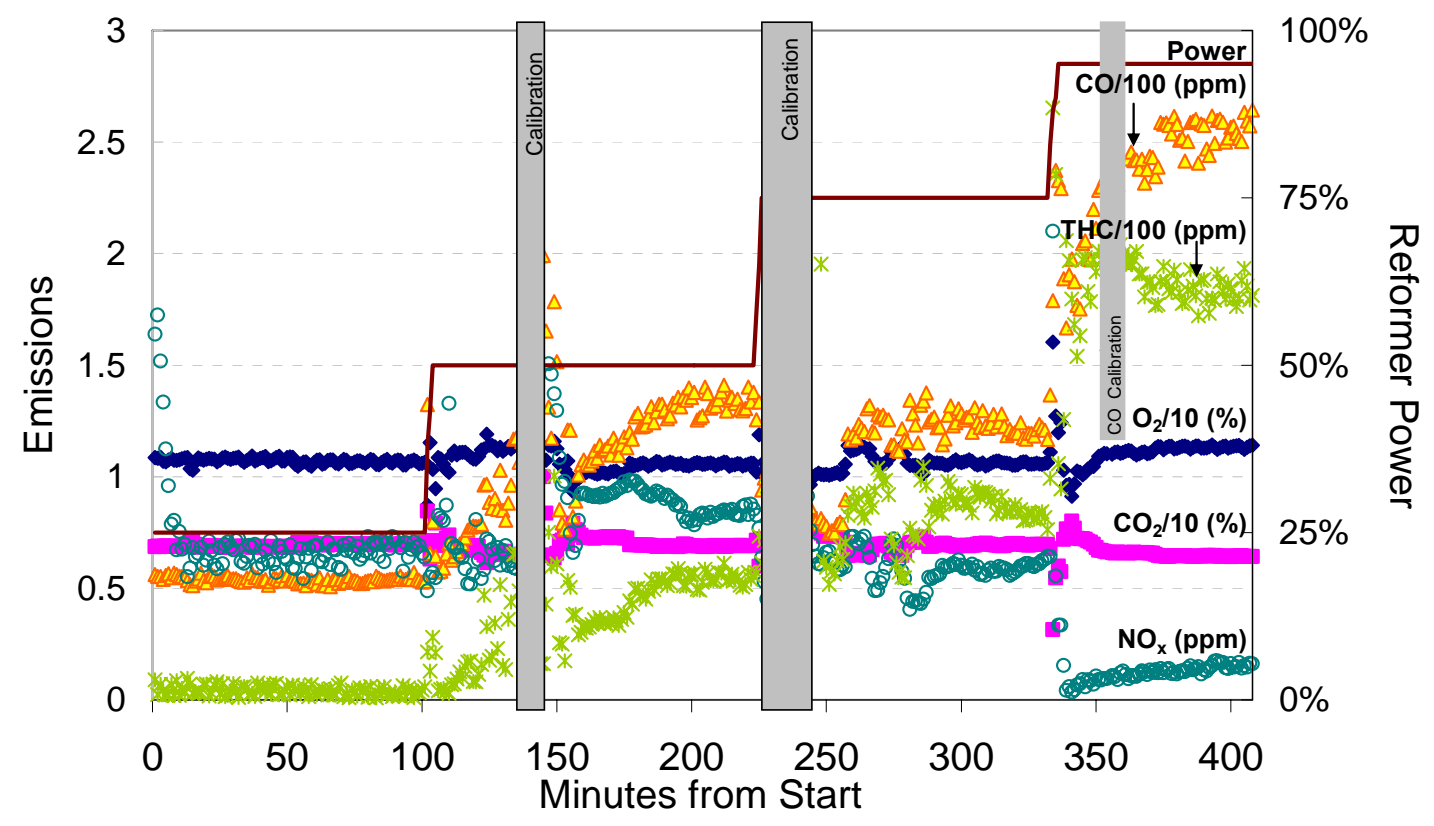

Figure 3-13. CEM Results at Burner Outlet, Nuvera Star ATR, October 14, 2004

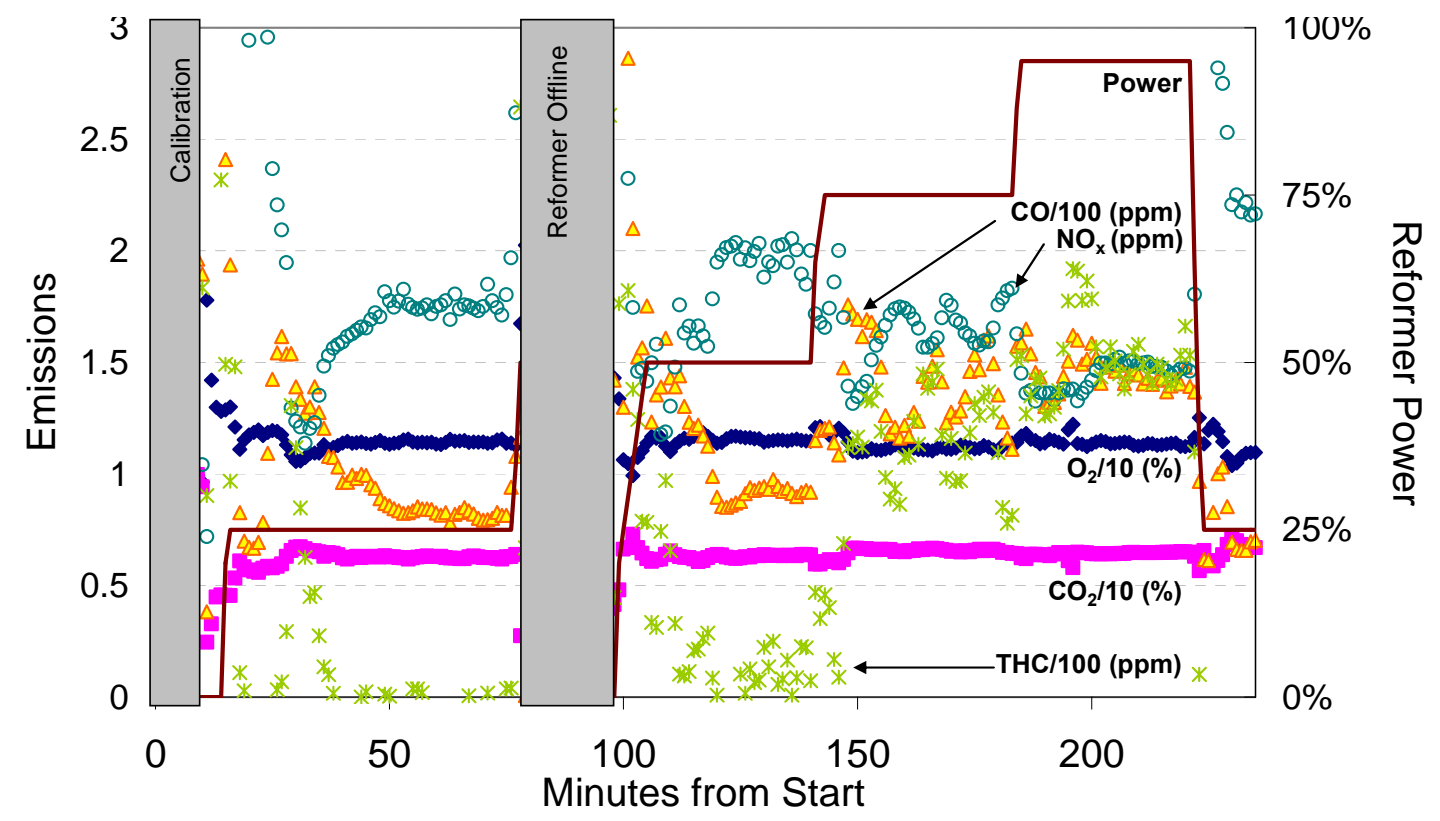

Figure 3-14. CEM Results at Burner Outlet, Nuvera Star ATR, October 15, 2004

The PrOx outlet emissions also varied between reformer systems. 


\subsection{PrOx Emission Results}

\subsubsection{MTI Gasoline PrOx CEM Results}

Emissions were monitored on a continuous basis for the PrOx on MTI fuel processor. The results are shown in Figures 3-15 and 3-16. Emissions from the PrOx provide insight into the composition of anode gas that would be burned by a fuel cell. The results from the MTI ATR show $\mathrm{NO}_{\mathrm{x}}$ emissions that are either undetectable or below $0.5 \mathrm{ppm}$. The presence of any $\mathrm{NO}_{\mathrm{x}}$ may be due to non homogenous mixing in the ATR. THC emissions were significantly higher than predicted for an ideal fuel processor system. The high level of THC emissions may reflect the part load condition at which the MTI fuel processor was operated.

\subsubsection{Nuvera Ethanol ATR/PEMFC PrOx CEM Results}

Emissions were monitored on a continuous basis from the PrOx of the Nuvera ethanol ATR/PEMFC system. The results are shown in Figures 3-17 and 3-18. The composition of the PrOx emissions can be related to emissions from the AGB in the prior section. THC emissions pass through the fuel cell and represent a likely upper limit to the THC form the AGB (on a g/sec basis). Some $\mathrm{NO}_{\mathrm{x}}$ emissions were observed but at very low levels. The $\mathrm{NO}_{\mathrm{x}}$ may be formed in near stoichiometric zones of the ATR. CO emissions reflect the levels of CO needed for the PEMFC operating. Emissions from the PrOx were relatively stable during all operating conditions except full load, where THC levels varied considerably.

\subsubsection{Nuvera Gasoline Star ATR PrOx CEM Results}

Emissions were monitored on a continuous basis from the PrOx exhaust of the Nuvera gasoline Star ATR system. The results are shown in Figures 3-19 and 3-20. PrOx emissions reflected the reducing conditions. $\mathrm{NO}_{\mathrm{x}}$ levels were zero except for a brief period during a transition to reforming.

\subsection{Speciated Hydrocarbon Data Results}

The speciation of hydrocarbon emissions is critical in determining the NMOG or non methane fraction, which are treated as criteria pollutants. The mix of methane and non methane hydrocarbons is shown in Figure 3-21. For most of the process conditions tested non methane HCs were less than 10 percent of the total. Consequently, THC measurements need to be adjusted to reflect regulated NMOG emissions.

Figure 3-22 shows the composition of the hydrocarbons in the non methane fraction. These values summarize the speciation results in Appendix A. The composition of the hydrocarbons does not closely represent the mix of gasoline fuel. A large fraction of the ethanol hydrocarbons are ethene. 


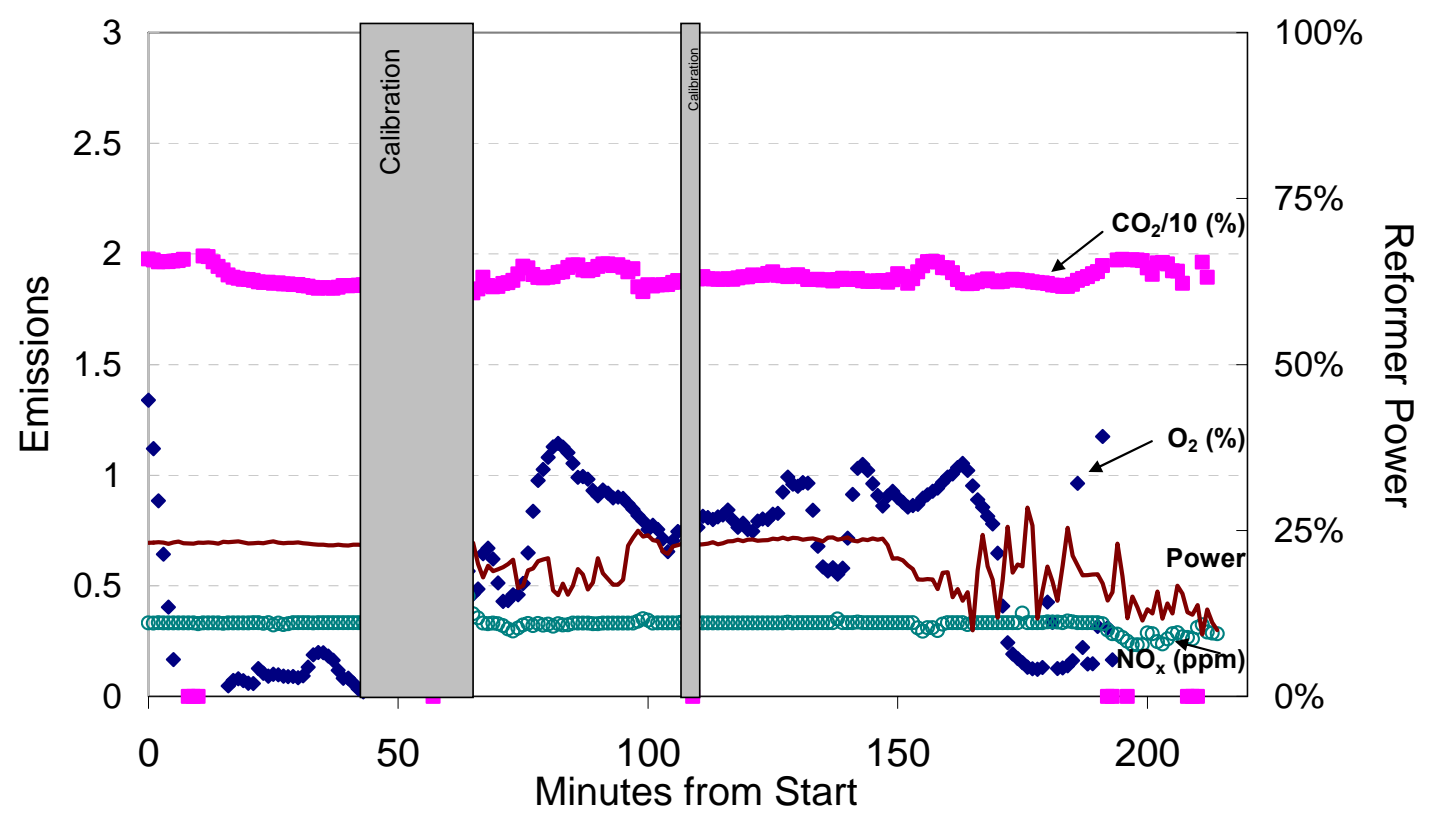

Figure 3-15. CEM Results at PrOx Outlet (RunA), MTI ATR, August 6, 2002

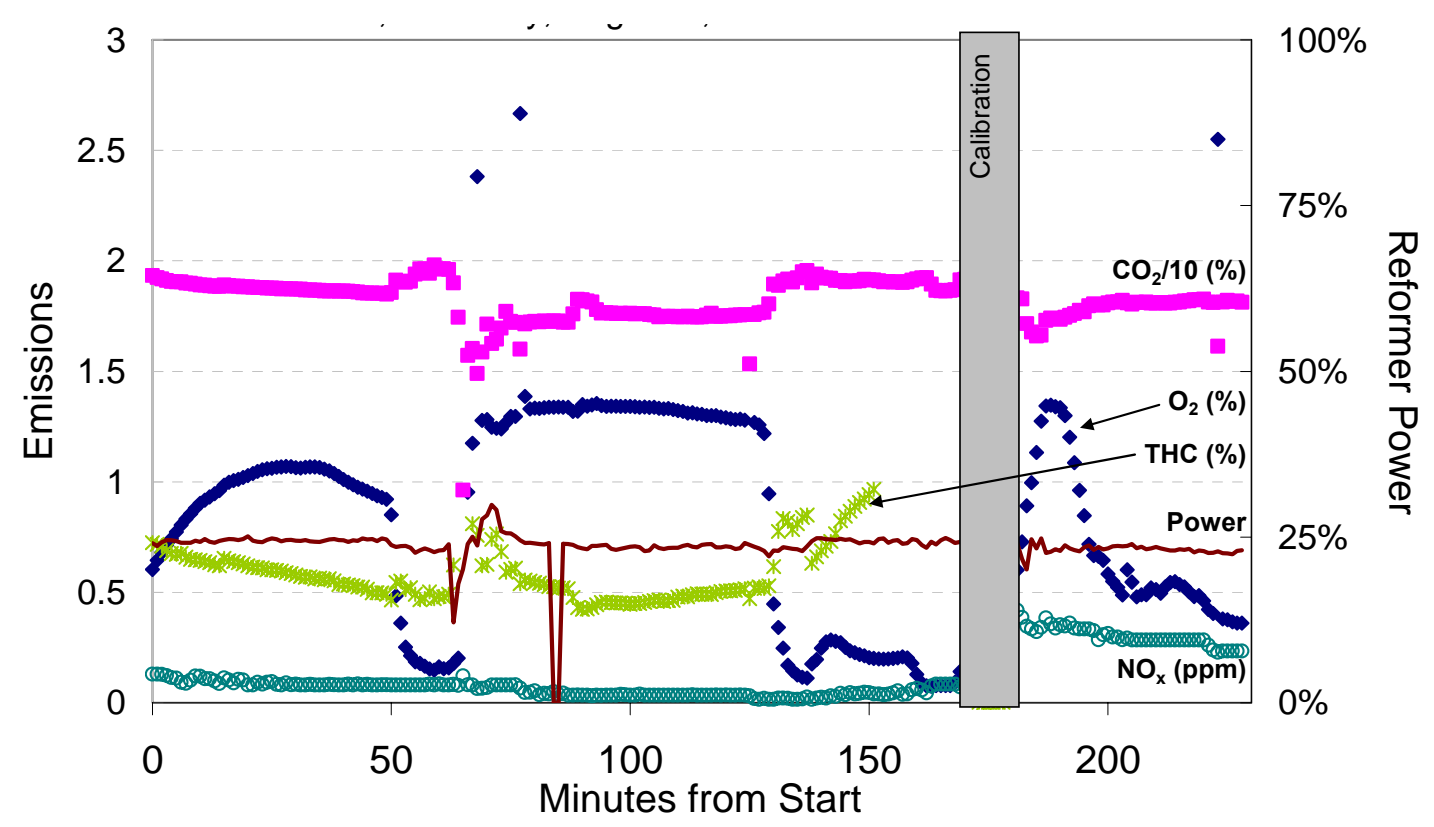

Figure 3-16. CEM Results at PrOx Outlet (RunC), MTI ATR, August 8, 2002 


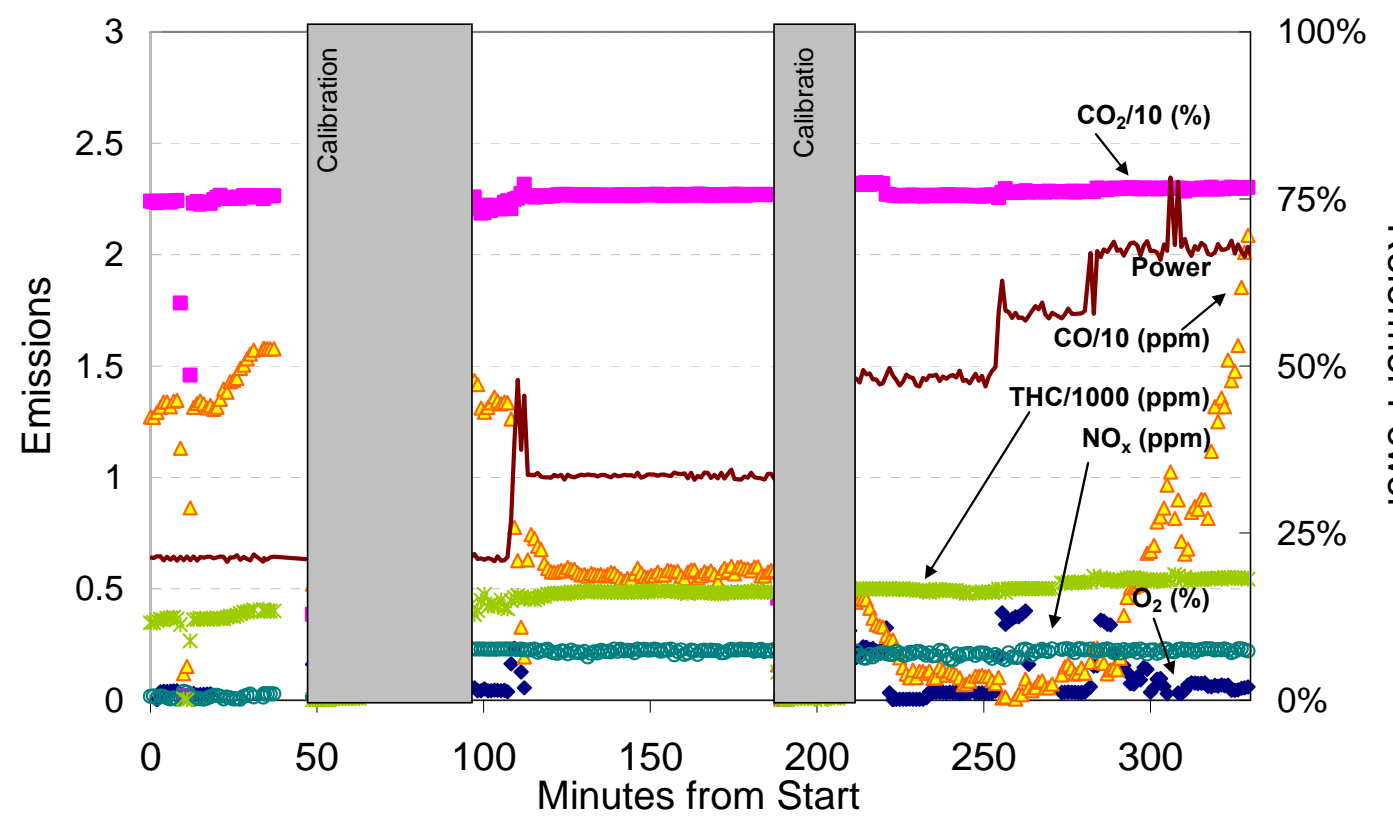

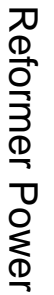

Figure 3-17. CEM Results at PrOx Outlet, Nuvera Ethanol ATR, February 25, 2003

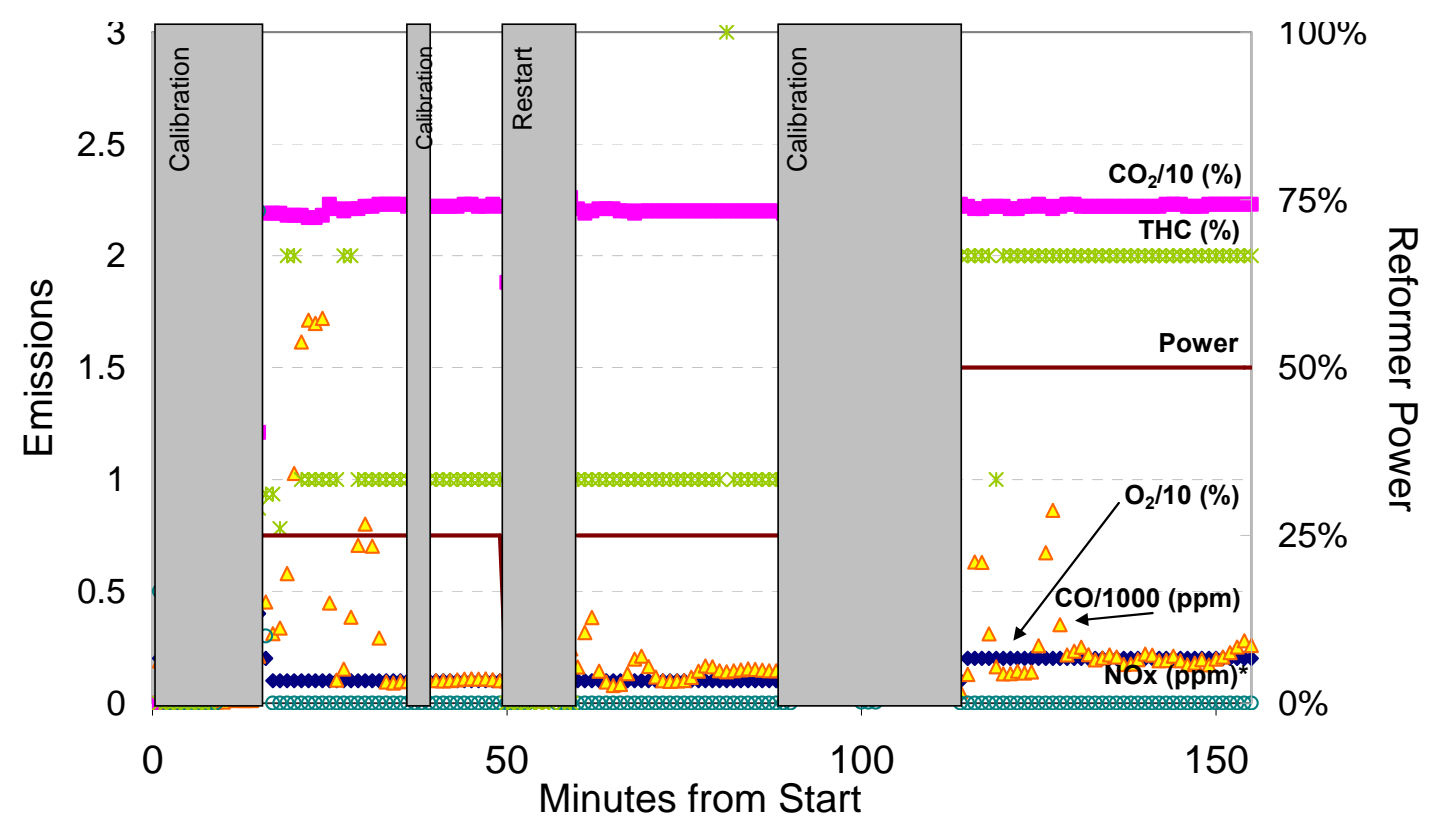

${ }^{*}$ After NOx calibration at 90 minutes, monitor was reading $2.4 \mathrm{ppm}$ while sampling $\mathrm{N}_{2}$. Assumed NOx is 0 at reading of $2.4 \mathrm{ppm}$ for remainder of test.

Figure 3-18. CEM Results at PrOx Outlet, Nuvera ATR, October 12, 2004 


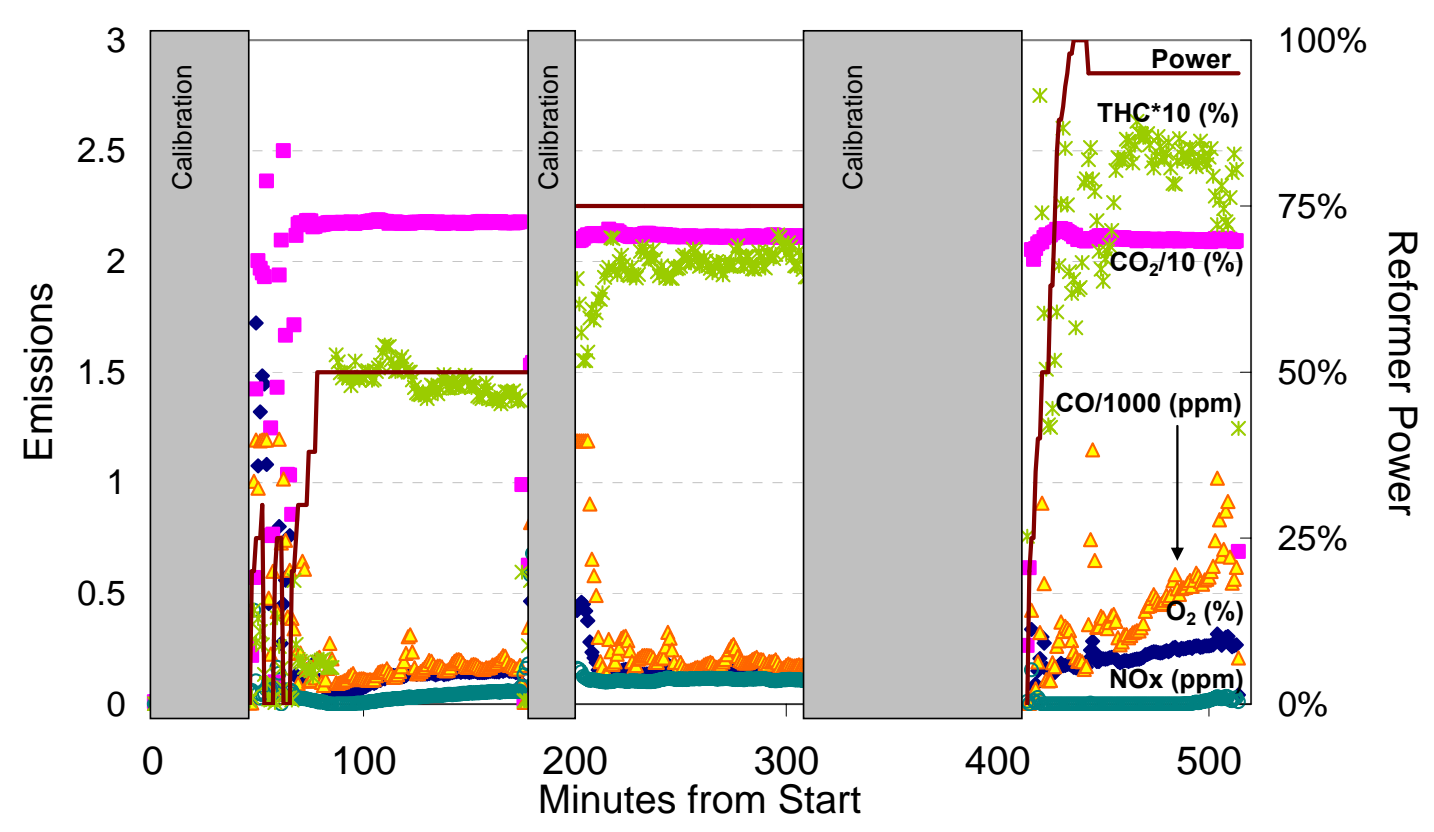

Figure 3-19. CEM Results at PrOx Outlet, Nuvera Star ATR, October 13, 2004

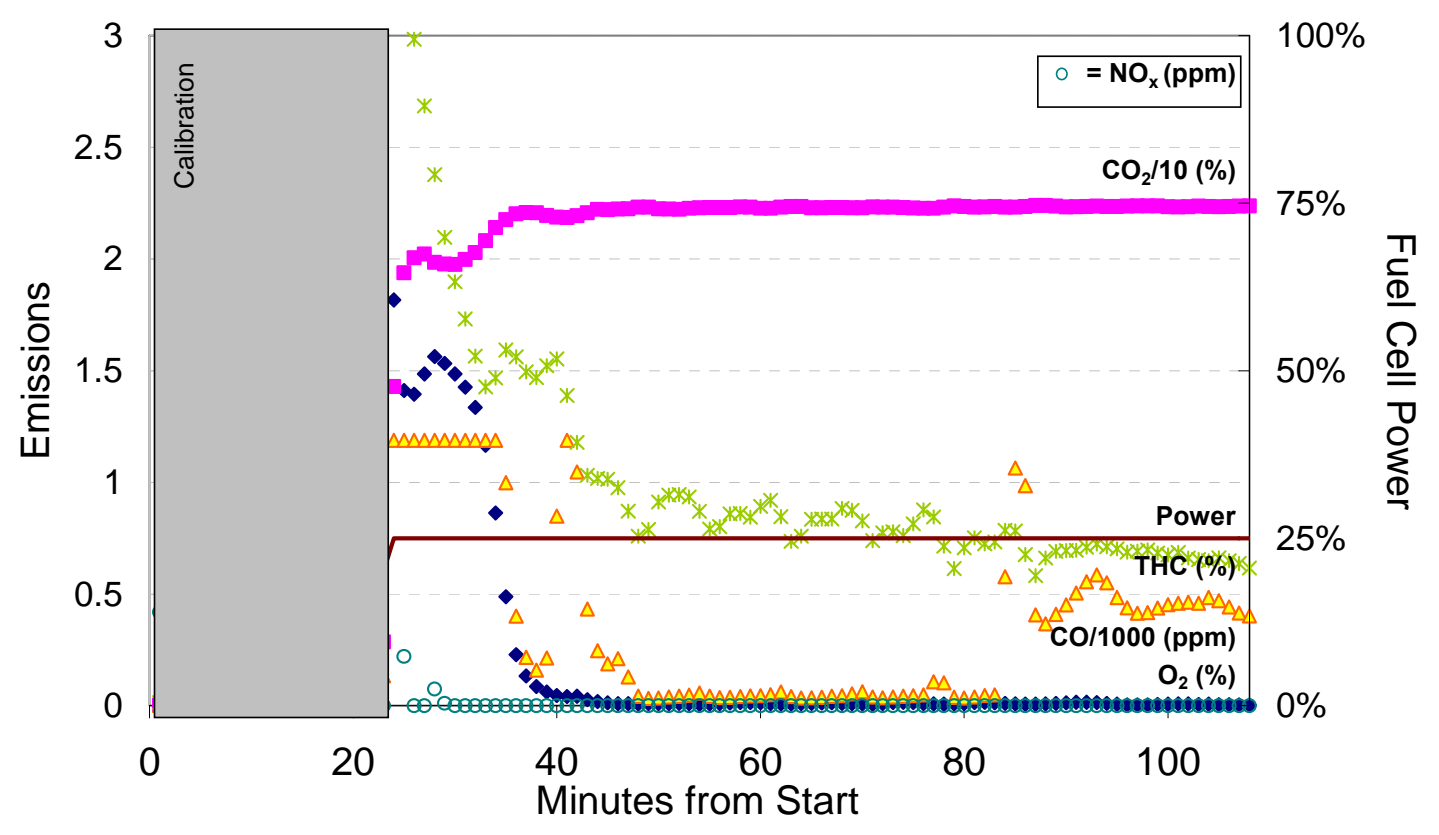

Figure 3-20. CEM Results at PrOx Outlet, Nuvera Star ATR, October 14, 2004 


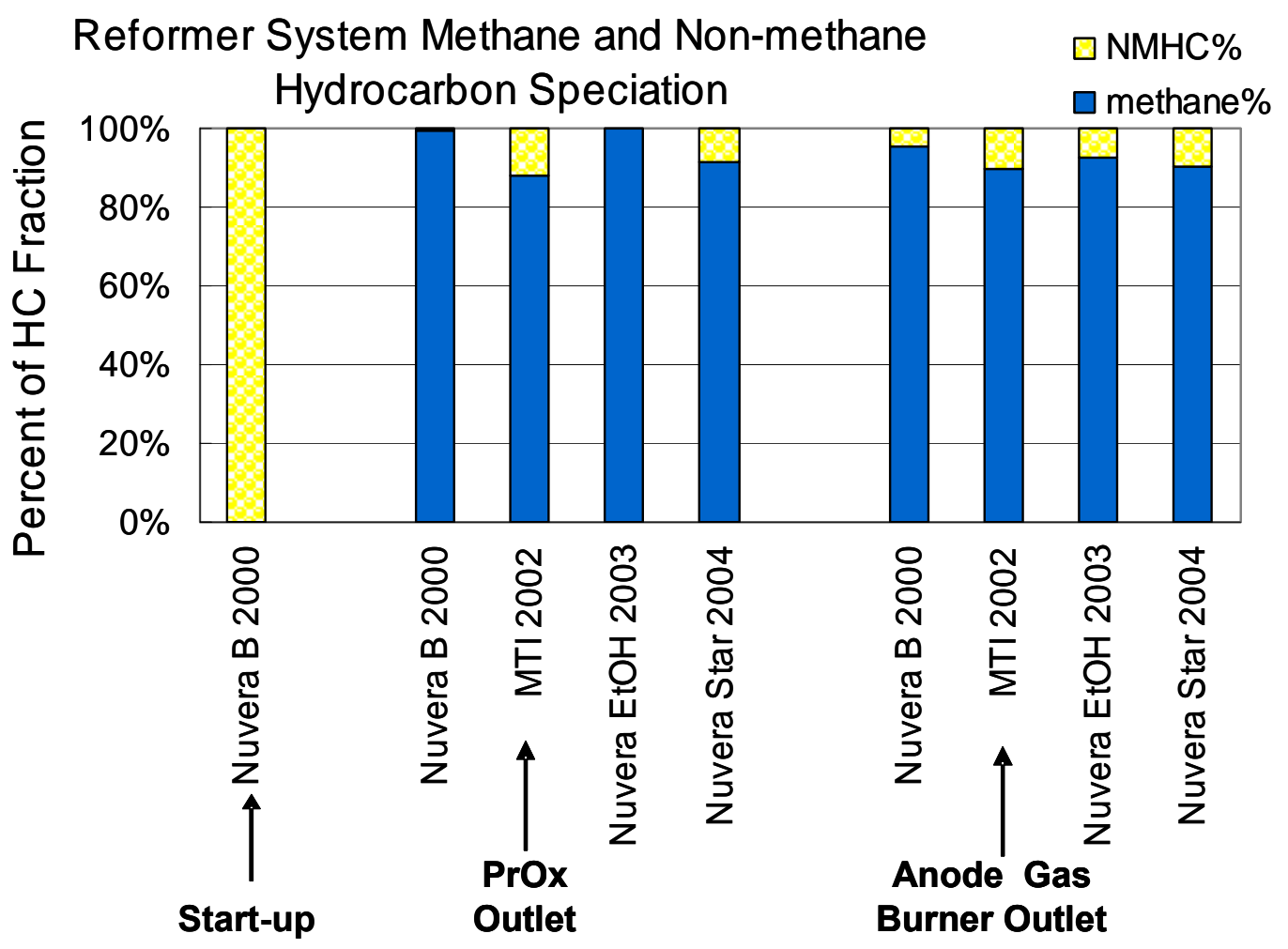

Figure 3-21. Methane and Non-methane hydrocarbon

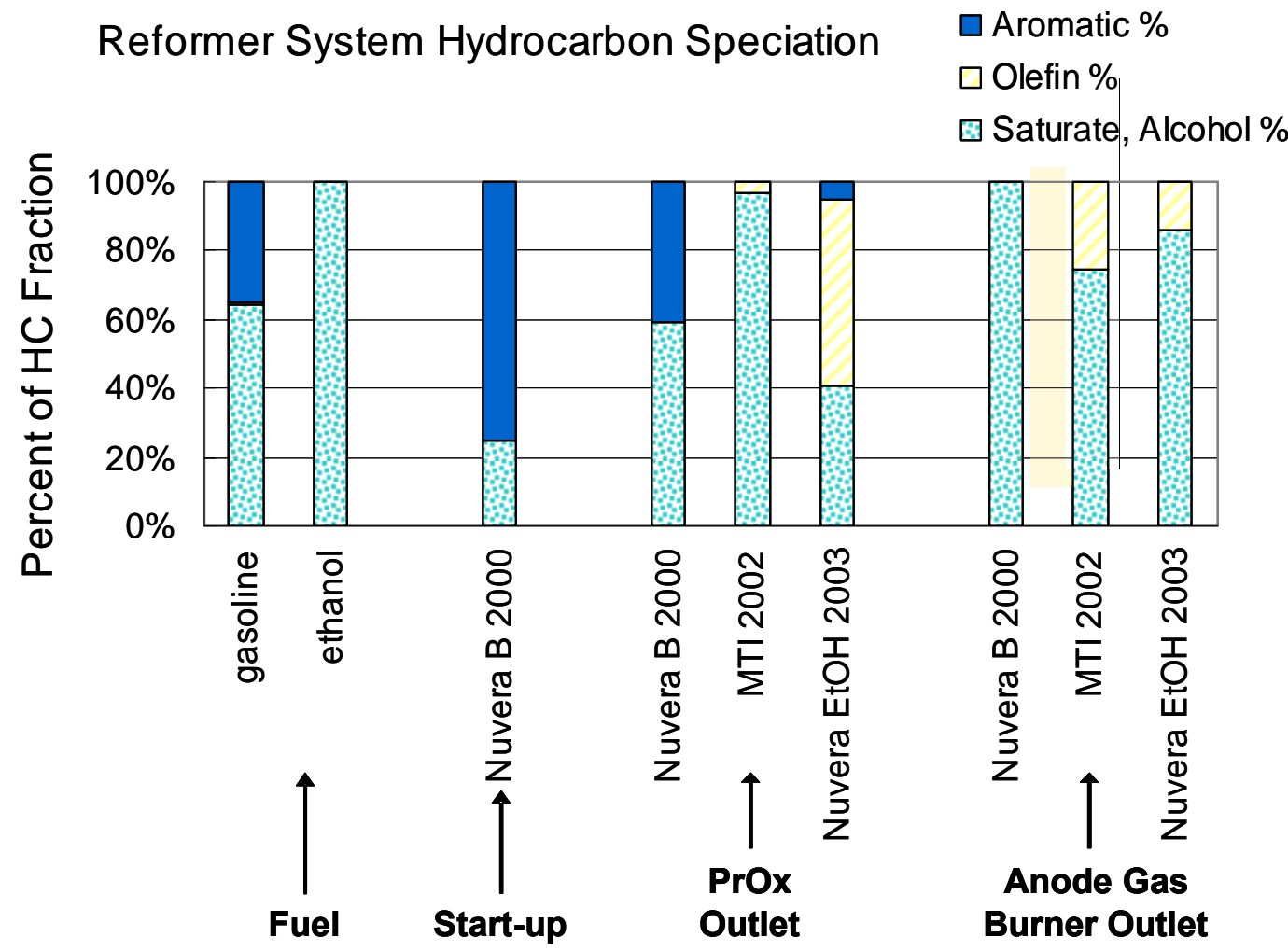

Figure 3-22. Speciation of non-methane hydrocarbons for various operation modes 


\subsection{Emission Testing - Interpretation and Discussion}

\subsubsection{Issues with emission testing}

Testing emissions from fuel processor systems provided many interesting insights into ATR operation. Several challenges and issues were also encountered during the course of the project including the following:

- A wide range of HC measurements was encountered during testing. THC levels tended to be highest at the PrOX and some of the hydrocarbons were destroyed in the AGB. With the wide range of system operating conditions THC levels ranged from 10 to $10000 \mathrm{ppm}$

- $\mathrm{NO}_{\mathrm{x}}$ emissions were sometimes observed in the PrOx gas, which is a reducing environment where $\mathrm{NO}_{\mathrm{x}}$ should not be present. The level of $\mathrm{NO}_{\mathrm{x}}$ was extremely low, and typically would not be detected by most equipment. We used analyzer settings that are more typical for ambient air quality measurements rather than gasoline vehicle exhaust in order to assess how low emissions from ATR/PEMFC vehicles could be. $\mathrm{NO}_{\mathrm{x}}$ emissions may have resulted from lean conditions in the ATR. The $\mathrm{NO}_{\mathrm{x}}$ that was detected was less than 100 times typical vehicle exhaust levels.

\subsubsection{Estimate of On-Board Fuel Processor Emissions}

The results of the emissions tests in this section were evaluated in order to assess the potential emissions from future ATR vehicles. A wide range of emission levels were observed from the different systems tested. These were developmental systems, not designed for vehicle operation. We assumed that the best emission levels during startup and reforming operation could be achieved on board a vehicle. Transient emissions could be managed with hybrid operation so that reformer load would not need to change too abruptly. Our estimate of these emissions is shown in Table 3-6. While it was a goal of the developers to provide a reformer system for fuel cell vehicles, the performance of these systems is too far from vehicle integration to assess how they might perform under a rigorous load following operating cycle.

\section{Table 3-6. Estimated Emissions from Fuel Cell Vehicle} with On-Board Fuel Processor (ppm)

\begin{tabular}{|c|c|c|}
\hline \multirow{2}{*}{} & \multicolumn{2}{|c|}{ g/per FUDS driving cycle } \\
\cline { 2 - 3 } & Startup & Driving \\
\hline \hline $\mathrm{NO}_{\mathrm{x}}$ & 20 & 0.3 \\
\hline $\mathrm{CO}$ & 1000 & 2 \\
\hline $\mathrm{PM}$ & 30 & 0.5 \\
\hline $\mathrm{NMOG}$ & 100 & 0.5 \\
\hline
\end{tabular}

The project results show that fuel cell vehicle with on-board fuel processors can meet stringent emission standards. Cold start emissions may be the most significant fraction of the vehicle’s emissions. The energy requirements and start up times for systems under 
development result in start up emissions that would exceed vehicle standards. Strategies for controlling start up emissions include reducing the mass of reformer systems, reducing start up time, and partitioning catalyst systems for partial start up. 


\section{On-road Emissions Estimate}

The objective of this program is to compare estimates of fuel cell vehicle emissions based on reformer and fuel cell emissions measurements to conventional vehicle emissions and to future vehicle emission standards. However, due to the inherent differences in the powertrains of these types of vehicles, such a comparison is only meaningful on a gram of pollutant per mile basis, and emission standards are in these terms as well. This section estimates the $\mathrm{g} / \mathrm{mi}$ emissions from fuel cell vehicles based on startup on operating.

Emissions data were characterized in terms of startup or reforming modes. Although current fuel processor technologies are not configured to follow a typical vehicle load profile, hybrid vehicle power management strategies may facilitate using such fuel processors. For this project, the fuel processor was operated at several steady-state points while emissions are monitored for the steady-state conditions and transients between load changes. The data collected during start up, different loads, and transients serve as inputs to a vehicle emissions model. Using these data, this vehicle emissions model then predicts the emissions for each second in a driving cycle based on load. Start-up emissions are considered along with the total driving emissions.

With the exception of $\mathrm{PM}^{17}$, the fuel processor emissions measured in this test program were converted from a volumetric basis (i.e., percent or $\mathrm{ppm}$ ) to a gram/mile basis based on the results presented in Section 4. Emission estimates were combined with the startup and power requirements for fuel cell vehicles that meet DOE's goals. An analysis of the powertrain requirements, startup energy, and driving cycle energy for ATR/PEMFC vehicles was described in a report for DOE. ${ }^{18}$

\subsection{Startup Emissions}

The ATR reformer system must be brought to operating temperature before hydrogen is produced in reforming mode. During the startup procedure, a burner must burn the on board fuel rather than reformate. Since the startup energy demand represents a significant portion of the energy for FCVs with on-board reformers.

TIAX modeled energy inputs based on catalyst volume, heat capacity, system mass, and operating temperature Startup energy requirements are dictated by the energy input to the catalyst beds. The active mass and estimated startup energy are shown in Figure 4-1. The energy is calculated from the catalyst bed operating temperature and its mass. The fuel cell generates power with hydrogen feed, even at low temperatures, so no startup energy input is required

17 Particulate matter is measured on a mass basis and, thus, PM emission on a gram/mile basis is obtained by dividing the total particulate mass by the number of miles in the driving cycle.

18 Lasher, S., J. Thijssen, S. Unnasch, “Guidance for Transportation Technologies: Fuel Choice for Fuel Cell Vehicles, Phase II Final Report”, available at http://www.cartech.doe.gov/pdfs/FC/192.pdf, February 2002. 


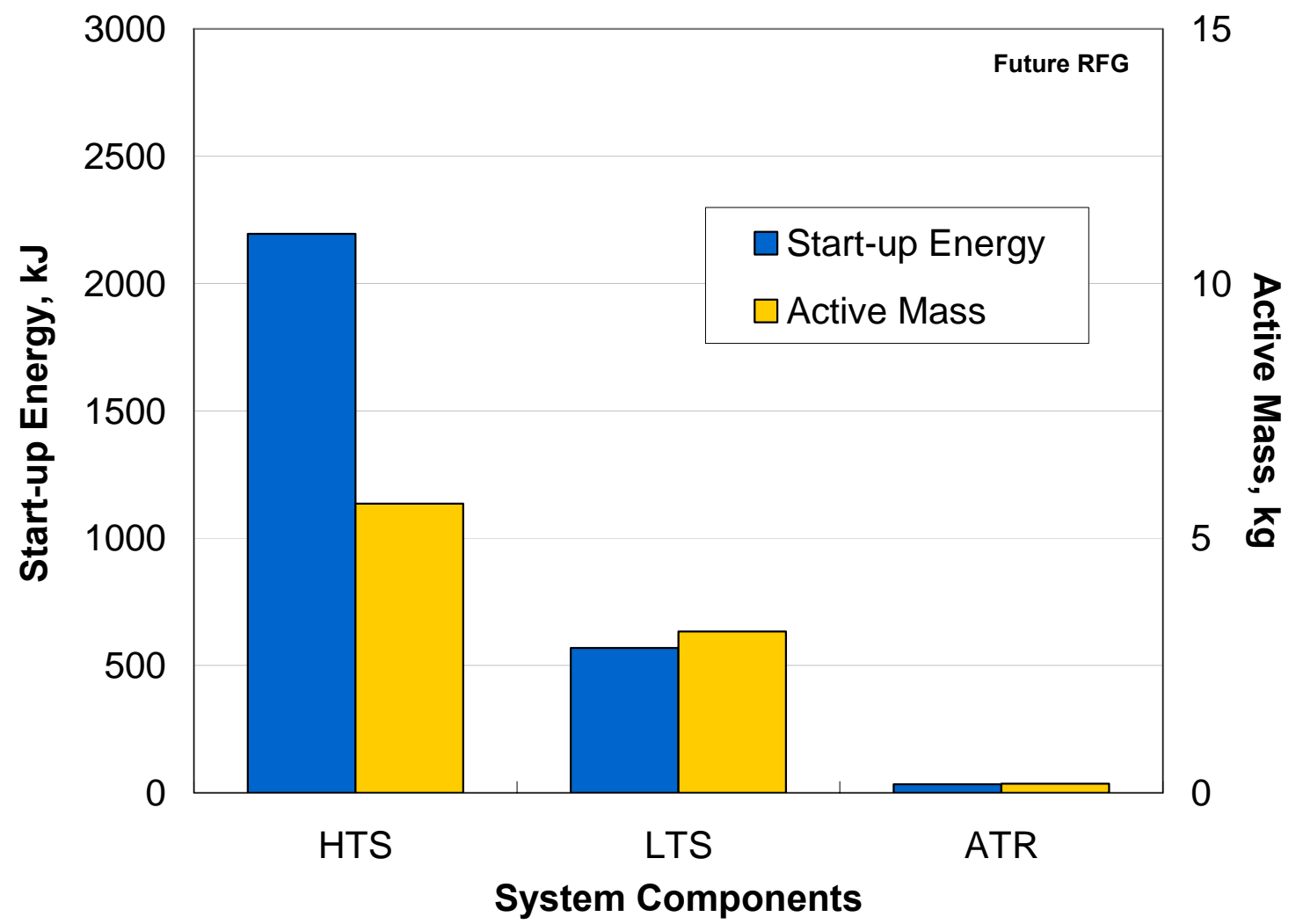

Figure 4-1. Estimated Energy Required to Startup Fuel Processor

Startup energy inputs may need to occur twice a day for typical driving and represents up to 10 percent of the drive-cycle energy Significant mass reductions in the fuel processor catalyst beds are projected

Starting the entire ATR represents a large fraction of the energy on a typical drive-cycle. As shown in Table 4-1, the energy required to warm up a $60 \mathrm{~kW}$ ATR could represent over 10 percent of the energy over the EPA city or highway driving cycle. The energy required to warm up the ATR can be reduced with several ATR downsizing strategies. A heavily hybridized vehicle with a large battery and smaller fuel cell would result in a smaller ATR and lower startup energy requirements. Analysis of the continuous top speed driving requirements for mid sized vehicles indicates a minimum fuel cell power rating of $39 \mathrm{~kW}$. Partitioning the catalyst beds into four independent systems can improve turndown and cold start energy rquirements. Partial startup on 25 percent of the HTS reduces startup energy (with a partitioned reformer). 
Table 4-1. Energy Requirements for Future RFG ATR FCVs

\begin{tabular}{|l|c|c|c|c|c|}
\hline \multicolumn{2}{|c|}{$\begin{array}{c}\text { Fuel Processor, } \\
\text { Startup Fraction }\end{array}$} & $\begin{array}{c}\text { Startup } \\
\text { Energy, kJ }\end{array}$ & $\begin{array}{c}\text { City Drive } \\
\text { Cycle, kJ }\end{array}$ & $\begin{array}{c}\text { Hywy Drive } \\
\text { Cycle, kJ }\end{array}$ & $\begin{array}{c}\text { CAFE Fuel } \\
\text { Economy } \\
\text { mpg }\end{array}$ \\
\hline \hline RFG ATR, 60 kW & $100 \%$ & 2,800 & 17,700 & 21,900 & 45.6 \\
\hline $\begin{array}{l}\text { RFG ATR, 38 kW } \\
\text { Large Battery } \\
\text { Hybrid }\end{array}$ & $100 \%$ & 1,770 & 15,600 & 20,600 & 52.2 \\
\cline { 2 - 6 } & $25 \%$ & 440 & 15,600 & 20,600 & 56.1 \\
\hline
\end{tabular}

\subsection{Drive Cycle Modeling}

On-road emissions were estimated from emission data and loads consistent with the Federal Urban Driving Schedule (FUDS). The FUDS, illustrated in Figure 4-2, is a schedule of vehicle speed as a function of test time used to simulate driving conditions in an urban environment. This driving schedule, which is approximately 23 minutes in duration, is used as the standard for quantifying vehicular emissions on a gram/mile basis. The combination of vehicle weight, driving cycle speed, and battery management strategies was used to determine the motor power demand shown in Figure 4-3. The motor power demand was used to estimate fuel cell power requirements over the driving cycle.

The powertrain architecture that assumed in this study is shown in Figure 4-4. This architecture represents a hybrid fuel cell vehicle with regenerative braking (i.e., positive and negative power demands in the figure) and hub motors (i.e., no power loss through the transmission).

Within the scope of this study the conversion from vehicle speed to fuel processor power demand is non-trivial, as several aspects of the fuel cell vehicle design will be assumed or approximated. For example, some of the fuel cell vehicle parameters that will be assumed for this study include:

- The vehicle frontal area

- The energy demand of the peripheral devices

- The efficiency of the reformer as a function of load

- The efficiency of the fuel cell as a function of load

In addition to these parameters, many design aspects of the fuel cell vehicle itself will be assumed as part of the conversion. 


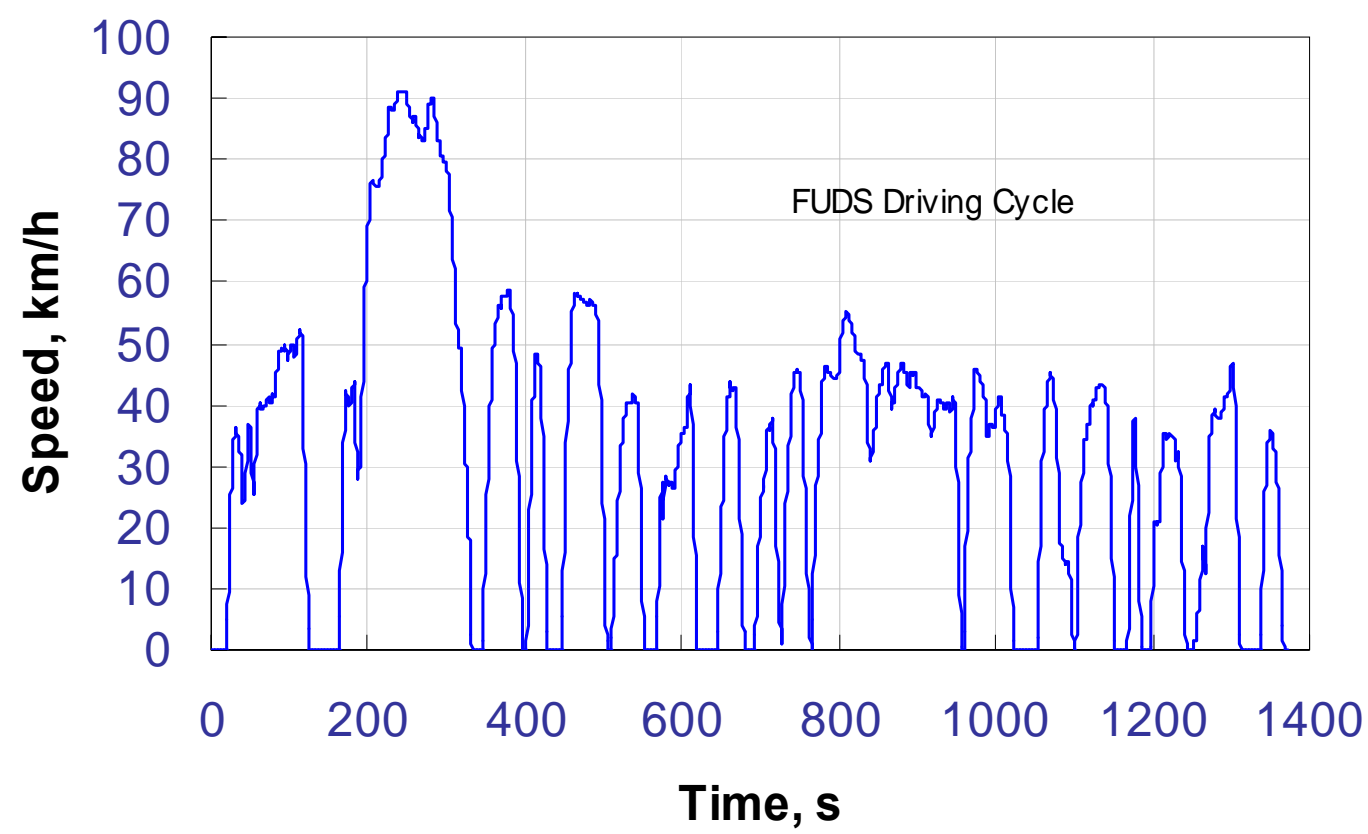

Figure 4-2. The Federal Urban Driving Schedule.

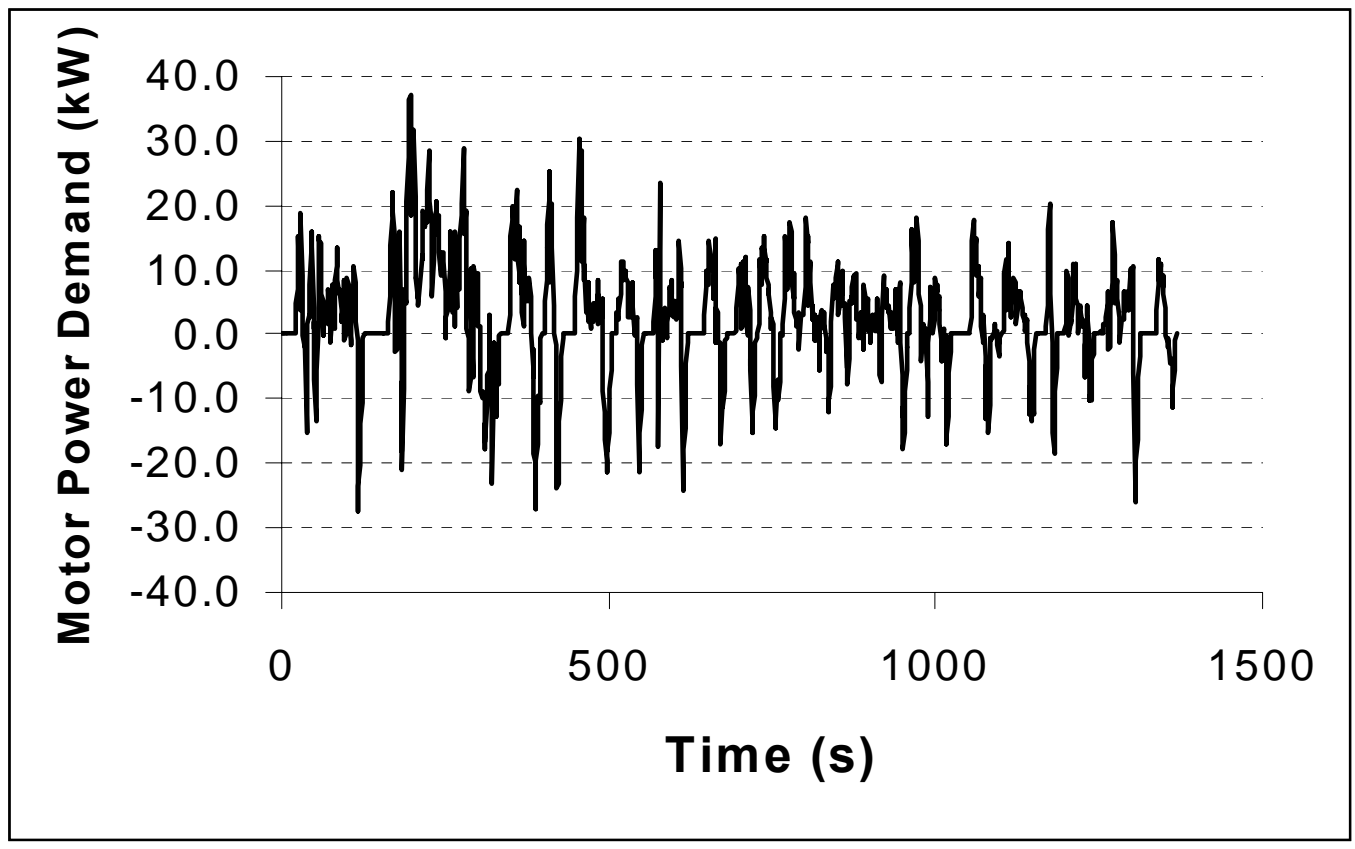

Figure 4-3. Motor Power Demand over the FUDS 


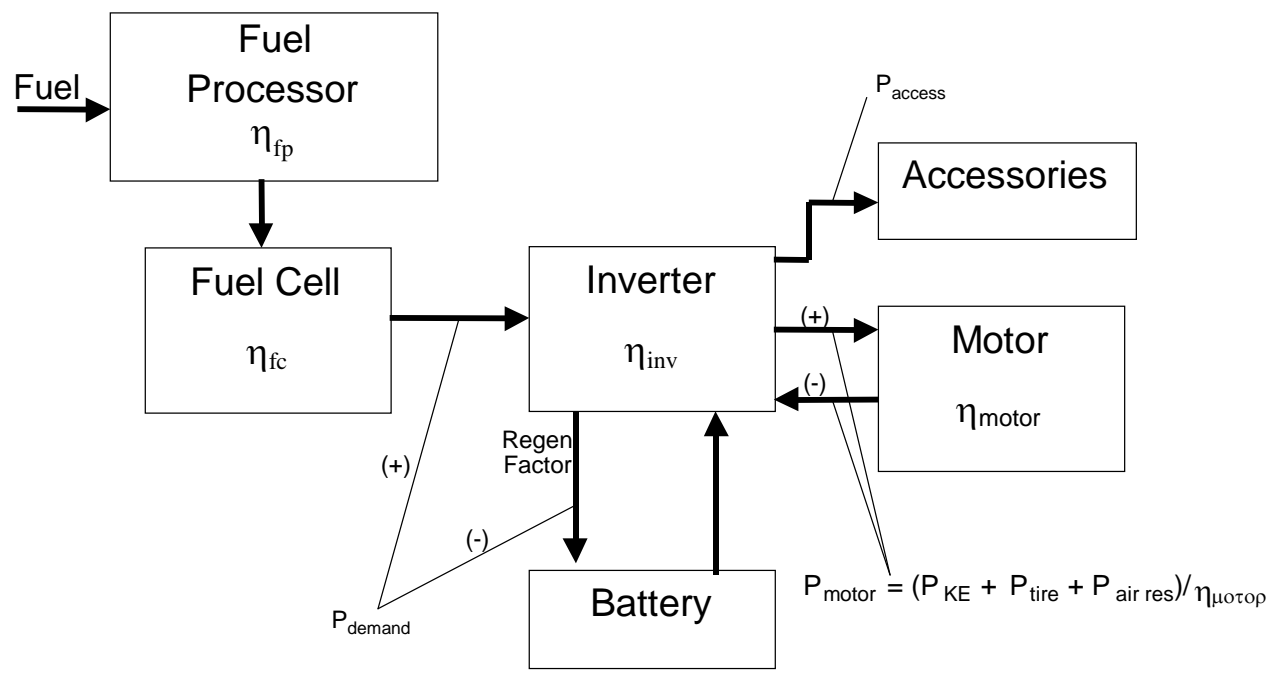

Figure 4-4. Fuel Cell/Battery Hybrid Vehicle Architecture

Based on the fuel cell vehicle architecture shown in Figure 4-4, the power required by the motor $\left(\mathrm{P}_{\text {motor }}\right)$ is:

$$
\mathrm{P}_{\text {motor }}=\left(\mathrm{P}_{\mathrm{KE}}+\mathrm{P}_{\text {tire }}+\mathrm{P}_{\text {air res }}\right) / \eta_{\text {motor }}
$$

where $\mathrm{P}_{\text {tire }}$ is the power required to overcome the tire rolling resistance, $\mathrm{P}_{\text {air res }}$ is the power required to overcome the air resistance, and $\eta_{\text {motor }}$ is the efficiency of the motor. $P_{\mathrm{KE}}$ is a direct function of the vehicle speed specified in the driving cycle of interest. Furthermore, $\mathrm{P}_{\mathrm{KE}}$ and, thus, $\mathrm{P}_{\text {motor }}$ may be positive or negative, depending on the acceleration of the vehicle.

By accounting for the power demand of accessories (e.g., fuel pump, compressor, and water pump) and the efficiency of the inverter $\left(\eta_{\text {inv }}\right)$, $P_{\text {motor }}$ will be converted into the power demand ( $\left.\mathrm{P}_{\text {demand }}\right)$ of the system. Under conditions in which $\mathrm{P}_{\text {demand }}$ exceeds the minimum fuel cell load, some combination of fuel cell power $\left(\mathrm{P}_{\mathrm{FC}}\right)$ and battery power $\left(\mathrm{P}_{\text {battery }}\right)$ will be used to meet $\mathrm{P}_{\text {demand. }}$. The fraction of $\mathrm{P}_{\text {demand }}$ that is met by $\mathrm{P}_{\mathrm{FC}}$ and $\mathrm{P}_{\text {battery }}$ will be determined by a defined power management strategy, in which the battery makes up for delays in the fuel cell/reformer power output and meets demand beyond fuel cell capacity. As a result of this strategy, the fuel cell and reformer are uncoupled from the road load of the vehicle and, instead, operate under conditions resulting in optimal efficiency.

Under other conditions in which the power demand is less than the minimum fuel cell load, but greater than zero, it will be assumed that the excess power from the fuel cell will be used for opportunistic charging of the battery. Finally, under still other conditions in which the power demand is less than zero, it will be assumed that the battery will be charged through a combination of regenerative braking and opportunistic charging. For this study, battery charging through regenerative braking will be a function of vehicle speed.

Using the vehicle architecture and defined power management strategy assumed in this study, the vehicle speed requirements will be converted into fuel cell stack (through the efficiency of the fuel cell, $\eta_{\mathrm{fc}}$ ) and, subsequently, processor power output and fuel input (through the efficiency of 
the fuel processor, $\eta_{\mathrm{fp}}$ ) requirements. For the motor power demand example shown in Figure 4-3, Figure 4-4 shows the corresponding fuel cell power output demand schedule for one battery management strategy. For the assumed fuel processor efficiency as a function of load illustrated in Figure 4-5, the fuel feed input power to the fuel processor would be as given in Figure 4-6.

The reformer and fuel cell system emissions tests discussed in Sections 2 and 3 measured reformer or fuel cell system AGB emissions of $\mathrm{NO}_{\mathrm{x}}, \mathrm{CO}$, and NMOG at various reformer/fuel cell loads or power outputs. Transient emissions over the duration of a load change were also measured. Emissions were quantified in volumetric concentration, i.e. ppm by volume. Thus, from these tests, emissions as a function of fuel feedrate to the fuel processor are known. The volumetric emission concentrations can be expressed as mass emission rates by knowing the AGB exhaust gas flow rate. Thus,

$$
\mathrm{M}=\mathrm{C} \mathrm{Q} F \mathrm{MW} / 10^{6}
$$

Where $\mathrm{M}$ is a constituent's mass emission rate $(\mathrm{g} / \mathrm{s}), \mathrm{C}$ is the contituent's concentration (ppm), q is the normalized (to fuel processor heat input) exhaust gas flow rate (mol/kJ), $\mathrm{F}_{\mathrm{fp}}$ is the fuel feedrate to the fuel processor $(\mathrm{kJ} / \mathrm{s}), \mathrm{F}_{\text {ag }}$ is the auxiliary fuel feedrate (if any) to the AGB $(\mathrm{kJ} / \mathrm{s})$, and MW is the constituent's molecular weight. The normalized exhaust gas flow rate can be calculated from the exhaust gas composition via carbon balance knowing the fuel processor and AGB auxiliary fuel compositions.

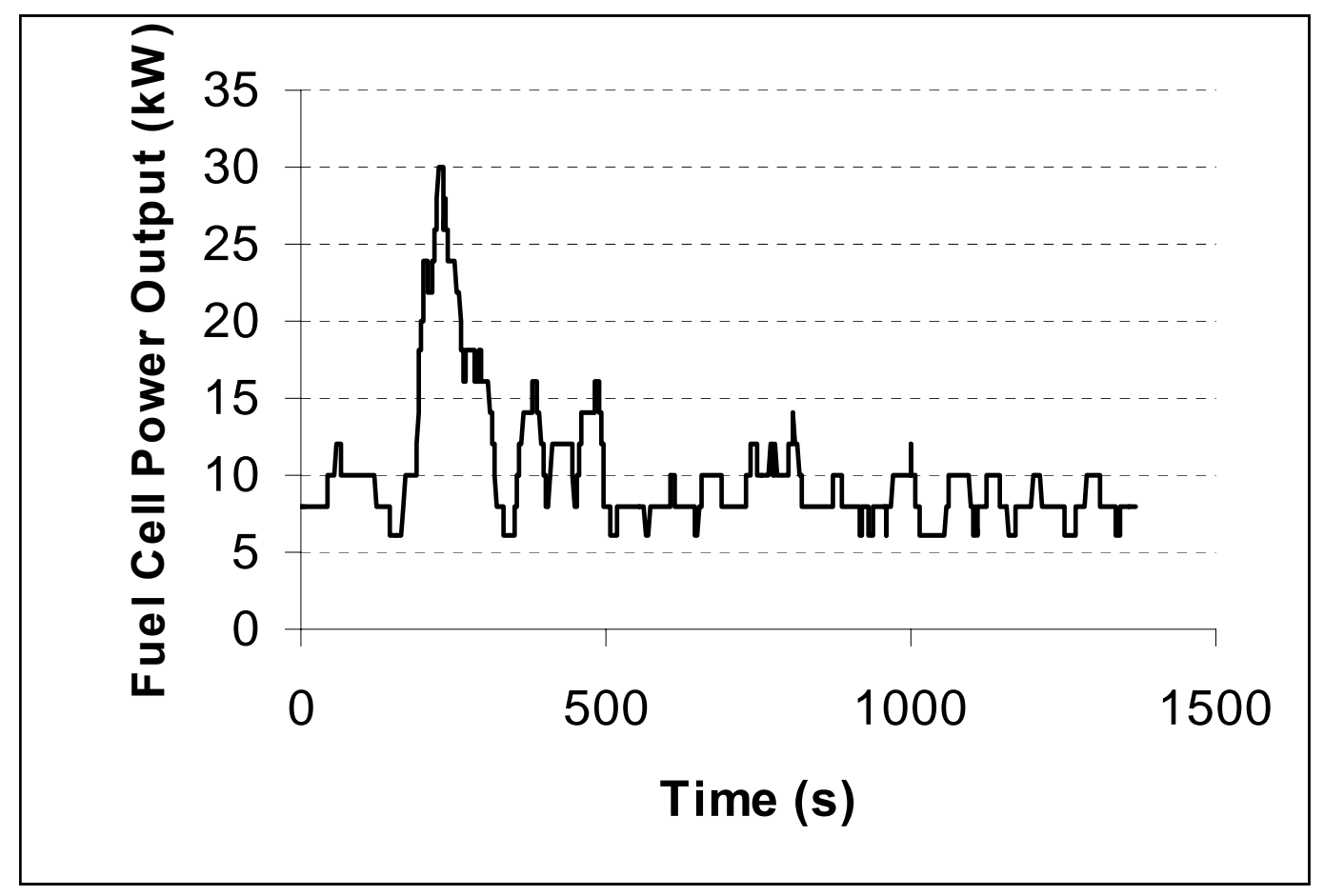

Figure 4-5. Fuel Cell Power Output for a Defined Battery Power Management Strategy for the Motor Power Demand Shown in Figure 2-2 


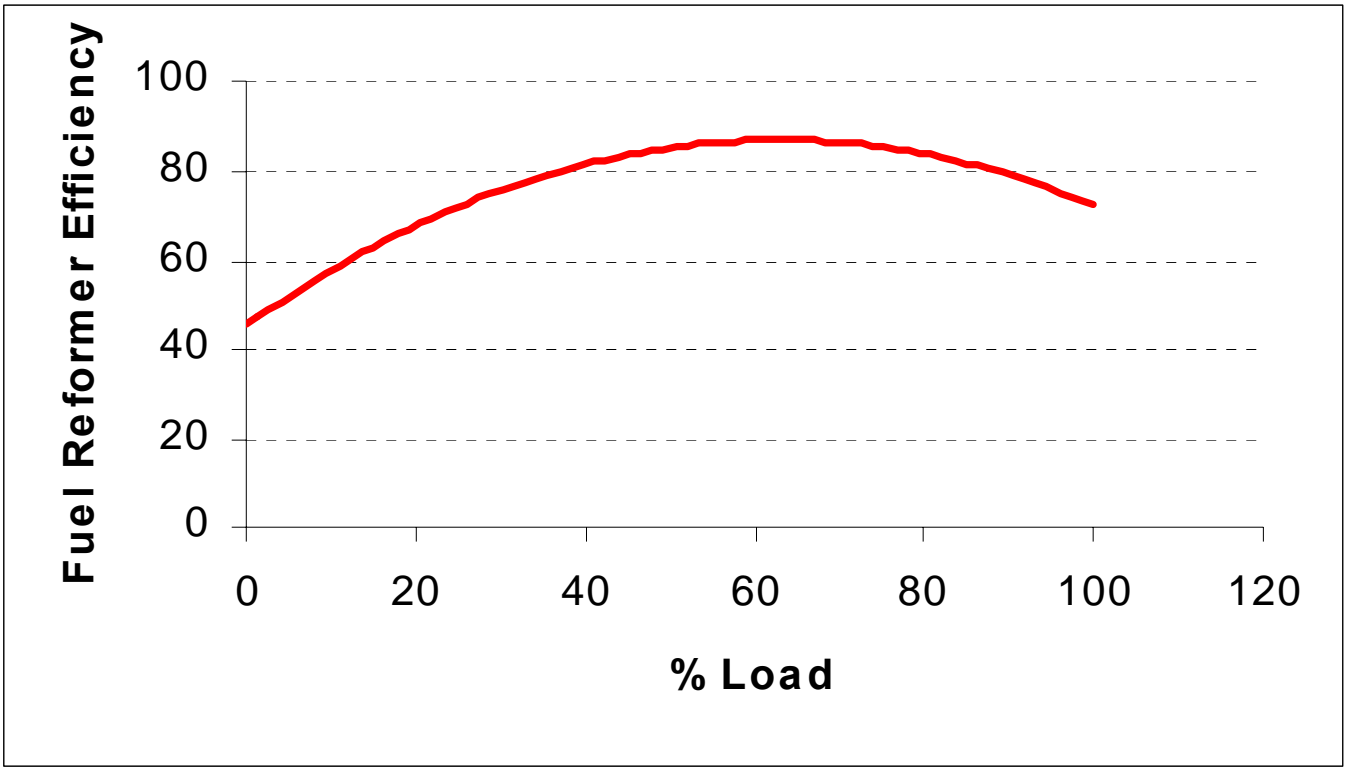

Figure 4-6. Assumed Fuel Processor Efficiency Versus Processor Load (Lasher 2002)

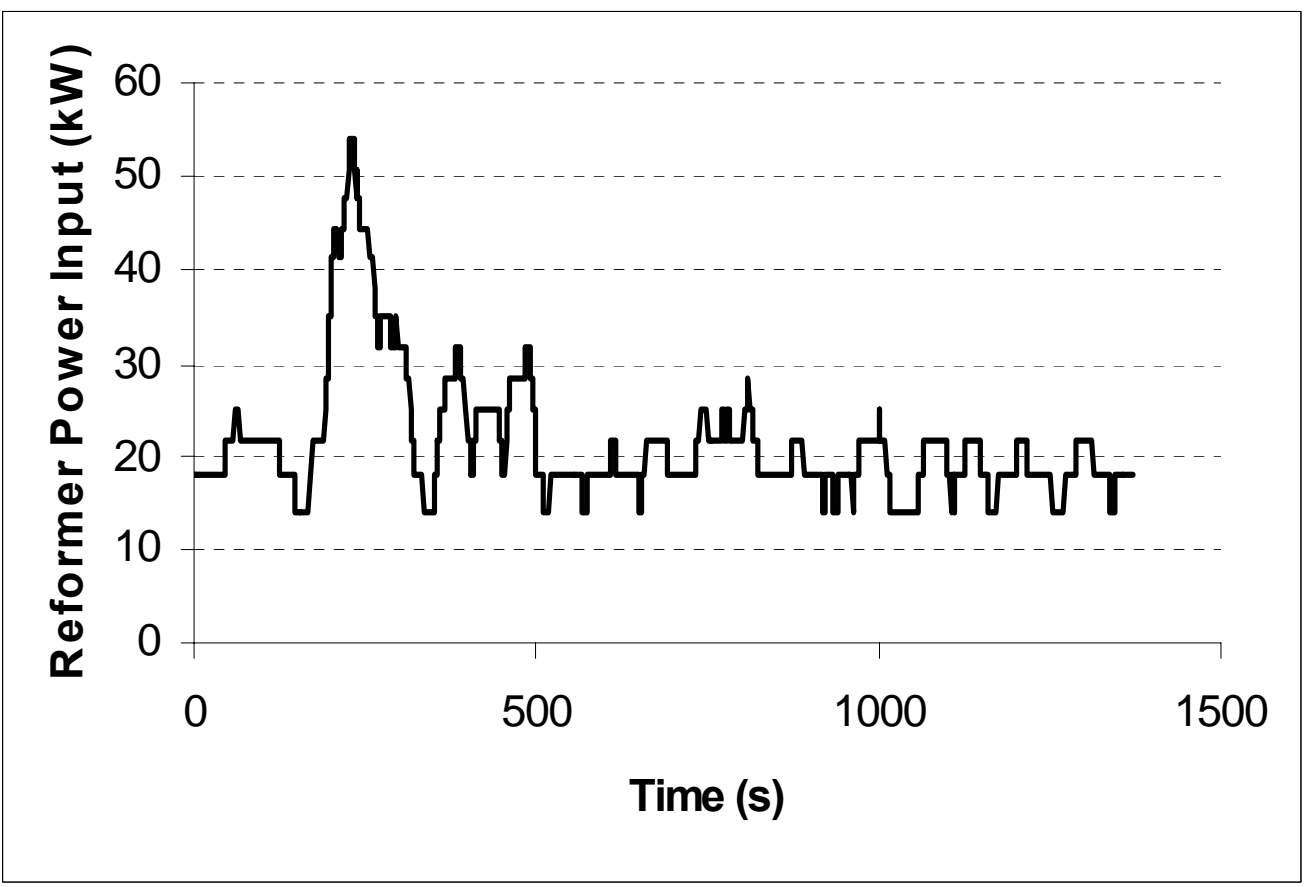

Figure 4-7. Fuel Processor Power Input to Supply the Fuel Cell Power Output in Figure 4-4 for the Efficiency Curve in Figure 4-5 
With knowledge of the AGB exhaust emission rates as a function of fuel processor load (or fuel feedrate), mass emissions can be calculated at each point in the driving cycle via mapping vehicle speed to fuel processor fuel feedrate through the procedure illustrates in Figures 4-1 through 4-6 above. Mass emission rates can then be integrated over the driving cycle to give total mass emissions over the cycle (g). Adding startup emissions and dividing by the total miles in the driving cycle give the emissions in $\mathrm{g} / \mathrm{mi}$.

\subsection{Emission Estimates}

Projected emissions for ATR/PEMFC vehicles are shown in Table 4-2. The emissions estimates are based on the startup energy for an ATR system with a segregated catalyst bed for warm up. Even with a segmented catalyst system, emissions during startup can be substantial. Catalytic control of hydrocarbon emissions may be necessary to achieve the lowest emission levels. Emissions during vehicle operation were estimated by developing an emission map for different reformer load conditions. No impact for transient operation was assumed since the ATR system would need to be part of a hybrid drive. The sum of the emissions from startup and operation were divided by the cycle driving distance to determine $\mathrm{g} / \mathrm{mi}$ estimates.

Table 4-2. Estimated Emissions from Fuel Cell Vehicle with On-Board Fuel Processor (g/mi)

\begin{tabular}{|l|l|l|l|l|}
\hline \multirow{2}{*}{ Pollutant } & \multicolumn{3}{|c|}{ g/per FUDS driving cycle } & g/mi \\
\cline { 2 - 5 } & Startup & Driving & Total & Total \\
\hline \hline $\mathrm{NO}_{\mathrm{x}}$ & 0.0081 & 0.00012 & 0.0082 & 0.0011 \\
\hline $\mathrm{CO}$ & 0.245 & 0.00049 & 0.25 & 0.033 \\
\hline $\mathrm{PM}$ & 0.026 & 0.00043 & 0.026 & 0.0036 \\
\hline $\mathrm{NMOG}$ & 0.053 & 0.00026 & 0.053 & 0.0071 \\
\hline
\end{tabular}




\section{Conclusion and Recommendations}

This project provides input to address technology barriers on fuel processing. Since data on the effects of fuel/fuel blend properties on the potential formation of toxic emissions are limited, testing was performed to quantify emissions from startup and fuel processor operation..

Fuel cell vehicles must meet the most stringent emission standards in order to provide value to the greatest number of stakeholders. Therefore, quantifying emissions from reformer systems needs to take into account very low detection limits in order to verify emission benefits. Data from fuel processor systems was used to evaluate potential emissions from vehicles with onboard fuel processors.

Results from this project indicated that fully developed fuel ATR/PEMFC vehicles can meet the most stringent emission standards, however, cold start emissions may need control of hydrocarbons. Furthermore, the energy required for cold start is a significant fraction of total vehicle driving energy. The fuel processor system may need to be partitioned for partial start and the vehicle hybridized to minimize the impact of transient operation.

Significant findings from this project include the following:

- Over 90 percent of hydrocarbon emissions from the PrOx or AGB are methane. Only the non methane portion counts towards HC or NMOG standards.

- Minimal $\mathrm{NO}_{\mathrm{x}}$ emissions were observed from the AGB burning hydrogen depleted reformate. Slightly higher levels (but still below $1 \mathrm{ppm}$ ) were observed when hydrogen rich reformate was burned. ATR/PEMFC vehicles should achieve the lowest $\mathrm{NO}_{\mathrm{x}}$ standards

- CO emissions form the PrOx were low to protect the PEMFC. When controlled to below $10 \mathrm{ppm}, \mathrm{CO}$ on a $\mathrm{g} / \mathrm{mi}$ basis is below the most stringent standards

- No ammonia was determined form the PrOx exit gas with a 1 ppm detection limit

- The combustion of reformer products at the AGB did not represent an optimized fuel cell vehicle configuration. Even with these limitations, the following conclusions can be drawn from the data.

- The AGB showed very effective in controlling THC emissions. THC Tail pipe emission levels were undetectable in many runs.

- In-use THC and CO emissions were under $0.2 \mathrm{ppm}$ and $3 \mathrm{ppm}$, respectively, which would correspond to on-road emissions well below the SULEV standards.

- Estimations of startup on-road NMOG and CO emissions with an optimized fuel processor have been difficult to produce with the small sample size currently available 
Based on the data and analysis efforts from this project, we recommend the following for future development efforts with integrated ATR/PEMFC systems:

- Continue monitoring speciated hydrocarbon emissions from both the PrOx and AGB in order to assess the fate and composition of hydrocarbons in the fuel cell system

- Continue to assess emission goals and select monitoring equipment and calibration gases to determine emissions at detection limits that relate to emission goals

- Develop strategies to minimize the energy consumed during reformer start up 


\section{Appendix A. Emission Sampling Procedures}

\section{A.1 HC, Formaldehyde, Ammonia Control Measures}

Leak checks were performed before and after sampling to ensure accurate sample volumes and avoid any dilution of the sample with ambient air. The pre-test sample train leak check was conducted at a vacuum of approximately 15 inches Hg. The post-test leak check was performed at a vacuum greater than or equal to the maximum value reached during the sampling run. The rate was noted on the field data sheets. In all cases, the leakage rate was required to be less than $0.02 \mathrm{ft}^{3} / \mathrm{min}$, to meet the acceptance criterion.

The following measures were implemented to ensure sample quality and to reduce any outside contamination or interference.

- The glassware was cleaned and capped according to the method prior to sampling.

- The probe, connecting glassware, and impingers were stoppered for return to the recovery area.

- Samples were refrigerated after sampling.

- Reagent blank samples were taken and analyzed.

- 10 percent QA samples (duplicates or spike analyses) were analyzed

\section{A.1.1 Continuous Emissions Monitoring}

The CEM system analyzers were calibrated before and after each test using a manufacturer's certified gas or Environics gas dilution analyzer. A leak check of the system was performed before the initiation of sample analyses. Multi-point calibrations of the CEM system analyzers were performed. When used, a field audit was performed on the Environics gas dilutions system according to EPA Method 205.

\section{A.1.2 Sample Tracking}

Numbered sample labels and chain-of-custody forms were used to identify and track samples from the field to the laboratory. Each sample was placed into an appropriate container, which was then labeled with the sample date and time, the sample location and site, the analytical method required, and the sample's unique identification number. Solution and filter blanks were treated as separate samples and packaged appropriately. The sample number, the location and site, and the date and time were noted on the corresponding chain-of-custody form. The field sample custody clerk retained responsibility for the samples until they are transferred to the laboratory. The chain-of-custody forms accompanied the samples to the laboratory, where the laboratory sample custodian accepted responsibility for the samples. Before samples were shipped to the laboratory, the field sample custody clerk verified the accuracy of the forms. 


\section{A.2 Procedures and Operation}

Process and exhaust gas constituent concentrations were measured following the methods summarized in Table 3-1. In order to maintain high levels of species of interest in the sample gas stream, dilution air was not added to the sampling stream. ${ }^{19}$ Sample gas was conditioned as needed for each species of interest. Concentrations of total $\mathrm{HC}, \mathrm{NO}_{\mathrm{x}}, \mathrm{O}_{2}, \mathrm{CO}$, and $\mathrm{CO}_{2}$ were measured continuously following EPA methods in 40 CFR Part 60. Filterable particulate matter was measured by filtering the entire exhaust stream using guidelines from EPA Method 5. Speciated HCs were measured following EPA Method 18 with analysis by gas chromatography/mass spectrometry (GC/MS). Ammonia was measured following Bay Area Air Quality Management District (BAAQMD) Source Test Method 1B (ST-1B). Formaldehyde was measured according to the NCASI 98.01 method. Additional details regarding the test procedures for each test parameter are provided in Table A-1.

Table A-1. Test methods Used for Emissions Sampling

\begin{tabular}{|c|c|}
\hline Species of Interest & Test Method \\
\hline Continuous Measurements & EPA Method 7E \\
$\mathrm{NO}_{\mathrm{x}}$ & EPA Method 10A \\
$\mathrm{CO}$ & EPA Method 25A \\
$\mathrm{THC}$ & EPA Method 3A \\
$\mathrm{O}_{2}, \mathrm{CO}_{2}$ & \\
\hline Integrated Samples & EPA Method 5, modified \\
Filterable Particulate Matter & EPA Method 18 with GC/MS analysis \\
Speciated HC & BAAQMD Method ST-1B \\
Ammonia & NCASI 98.01 \\
Formaldehyde & BAAQMD Ethanol \\
Alcohols (ethanol, methanol) & \\
\hline
\end{tabular}

Downstream of the PrOx or exhaust burner (depending upon which test run was being performed) a sample manifold was inserted to distribute sample gas to the continuous emission monitoring (CEM) analyzers. During runs where we measured PM, exhaust from the burner was directed through an exhaust duct bypass to a 2- or 6-inch particulate matter filter and then back into the exhaust duct. The filter system and manifold system was heated/insulated, as needed, to prevent condensation. Integrated sampling for the speciated HCs was collected in evacuated Summa canisters or Tedlar bags. Integrated sampling for ammonia, formaldehyde, and alcohols were collected separately through chilled impingers, as described in Sections 3.4 through 3.6. All sampling was performed at a constant sampling rate.

${ }^{19}$ A known amount of dilution may occur in the main exhaust stream as part of normal reformer system operation. 


\section{A.2.1 CEM Analysis: Total $\mathrm{HC}, \mathrm{NO}_{x}, \mathrm{O}_{2}, \mathrm{CO}$, and $\mathrm{CO}_{2}$}

Concentrations of total $\mathrm{HC}, \mathrm{NO}_{\mathrm{x}}, \mathrm{O}_{2}, \mathrm{CO}$, and $\mathrm{CO}_{2}$ were measured continuously using the instrumentation identified in Table 2-2. These parameters were measured according to EPA test methods in 40 CFR Part 60 . Prior to testing, the TIAX sampling and monitoring system was assembled and leak-checked. Once all analyzers were in place, total $\mathrm{HC}, \mathrm{NO}_{\mathrm{x}}, \mathrm{O}_{2}, \mathrm{CO}$, and $\mathrm{CO}_{2}$ were monitored at the burner exhaust point and at the PrOx outlet.

Table A-2. TIAX CEM Analyzers

\begin{tabular}{|c|}
\hline $\begin{array}{ll}\text { - } & \text { Total HC Flame Ionization Detector-JUM VE7 } \\
\text { - } & \mathrm{NO}_{x} / \mathrm{NO} \text { Chemiluminescent Analyzer-ECO Physics } \\
\text { - } & \mathrm{O}_{2} \text { Analyzer-ServoMex } \mathrm{CO}_{2} / \mathrm{O}_{2} \text { Analyzer or similar } \\
\text { - } & \mathrm{CO} \text { Infrared Analyzer-HORIBA Model VIA } 510 \\
\text { - } & \mathrm{CO}_{2} \text { Analyzer-ServoMex } \mathrm{CO}_{2} / \mathrm{O}_{2} \text { Analyzer or similar }\end{array}$ \\
\hline
\end{tabular}

Each TIAX analyzer used a sample pump to extract sample gas continuously from a manifold in the sample gas line. The sample gas was conditioned to remove moisture using an impinger ice bath technique. The gas flow of conditioned sample gas was controlled with a back-pressure regulator and individual rotameters through the analyzer. Instrument output was recorded using a strip chart recorder and a digital data logger

Total HC concentrations were measured as methane. For reporting purposes, concentrations were converted to ppmv as carbon. Carbon attributable to methane was subtracted from the total carbon measurement to determine the total non-methane-hydrocarbon value. Methane concentrations were measured by collecting sample gas in evacuated canisters and later determining speciated hydrocarbons within that sample. Methane analyses was performed in a separate gas chromatography run using a pre-concentration direct flame ionization detector. In order to protect the confidentiality of reformer system performance, methane measurements will not be reported explicitly.

Calibrations were performed for each of the instruments using certified calibration gases. An analyzer calibration error check was performed on each instrument to assess instrument linearity. For this check, calibration gases were introduced to each instrument, and the responses recorded on a field data sheet. If the difference between the known concentration of each calibration gas and the analyzer response wa within 2 percent for each of the calibration gases, then the analyzer calibration error check was considered valid. A bias calibration check was performed prior to each sample run, and a bias span drift check performed at the end of each run to measure analyzer drift. The bias drift check measurement used a zero gas (nitrogen) and either a midrange or high-range calibration gas, whichever most closely approximated the stack gas concentration. 


\section{A.2.2 Extractive Sampling: Particulate Matter}

Particulate matter was measured at the exhaust location using an in-line filter, as filtering the entire gas stream removes potential issues of obtaining representative samples isokinetically. A nominal 6-inch filter with $0.8 \mu \mathrm{m}$ pore size was used to collect filterable particulate. As recommended in EPA Method 86.1309-90, the filter was maintained at $235^{\circ} \mathrm{F} \pm 15^{\circ} \mathrm{F}$. As the exhaust gas stream is at or near this temperature range, the filtration unit was insulated to maintain gas temperature if needed. ${ }^{20}$ A thermocouple was used to monitor the temperature at the filter inlet.

Filters was weighed prior to testing and weighed after testing is completed. The difference between these weights represents the mass of the particulate matter collected in the sample. Filters was desiccated prior to weighing. As prescribed by EPA Method 5, filters was weighed at less than 50 percent humidity and $68^{\circ} \mathrm{F} \pm 10^{\circ} \mathrm{F}$.

\section{A.2.3 Extractive Sampling: Speciated HC}

Hydrocarbons was sampled according to EPA Method 18. Gas samples was collected into a 1liter or 6-liter evacuated Summa canister. The sample gas was conditioned to remove moisture using an impinger ice bath technique. Moisture collected in the ice bath was analyzed to determine if HCs condensed with the moisture. In the event of high sample gas moisture at the sample location, the cylinder grab samples was diluted with a known volume of nitrogen prior to sampling. Conditioned sample gas was indirectly drawn into the sample cylinder using the EPA Method 18. Sample lines was Teflon ${ }^{\mathrm{TM}}$ tubing. All samples was grab samples providing instantaneous measurements of HC. Several grab samples was taken over each test period.

HC species collected in the grab sample canisters was analyzed by GC/MS. The analyses of the cylinders was performed by Air Toxics, Limited in Folsom, California. A clean grab sample cylinder filled with ultra-pure nitrogen was submitted to Air Toxics as a field blank.

\section{A.2.4 Extractive Sampling: Formaldehyde}

Formaldehyde concentrations was measured using NCASI 98.01, modified. Sample gas was drawn from a manifold through a series of 2 midget impingers containing $15 \mathrm{~mL}$ each of 2,4 dinitrophenylhydrazine (DNPH) at a rate of 0.5 cubic liters per minute for the length of one test cycle.

Formaldehyde concentrations in the impinger samples was measured according to NCASI 98.01. Impinger samples was analyzed for formaldehyde using high performance liquid chromatography (HPLC) following extraction. Air Toxics, Limited will perform the analysis for formaldehyde. For the majority of two-impinger sample sets, the solutions from each impinger was combined for one analysis. For select runs, the solutions from each impinger was analyzed separately determine if there was significant breakthrough. A field blank sample was collected and analyzed with the samples.

20 If the exhaust stream at the PM filter is normally below the temperature indicated, the entire exhaust gas stream was filtered through a heated filter system in accordance with EPA Method 5, modified. 


\section{A.2.5 Extractive Sampling: Ammonia}

Ammonia emissions was measured following BAAQMD Method ST-1B, modified. Sample gas was drawn from a manifold through a series of 2 impingers containing $0.1 \mathrm{~N}$ hydrochloric acid at a constant rate of 0.5 cubic feet per minute (CFM). The procedure was modified to extend sample collection for one test cycle.

These impinger samples was analyzed by spectrophotometry according to BAAQMD Analytical Procedure Lab-1. Severn Trent Laboratories, located in Sacramento, California, will perform the analysis of ammonium ion. For the majority of two-impinger sample sets, the solutions from each impinger was combined for one analysis. For select runs, the solutions from each impinger was analyzed separately determine if there was significant breakthrough. A field blank sample was collected and analyzed with the samples.

\section{A.2.6 Extractive Sampling: Alcohol}

Alcohol samples were analyzed along with the integrated HC samples collected in $1 \mathrm{~L}$ and $6 \mathrm{~L}$ evacuated canisters. See Section 3.3 for a description of canister sampling process.

\section{A.3 Field Test Equipment}

All measurement devices (i.e., thermocouples, balance for weighing, dry gas meter, orifice, and Magnehelic gauges) will be calibrated before and after the test program using procedures specified by EPA methods.

\section{A.4 HC, Formaldehyde, Ammonia Control Measures}

Leak checks will be performed before and after sampling to ensure accurate sample volumes and avoid any dilution of the sample with ambient air. The pre-test sample train leak check will be conducted at a vacuum of approximately 15 inches Hg. The post-test leak check will be performed at a vacuum greater than or equal to the maximum value reached during the sampling run. The rate will be noted on the field data sheets. In all cases, the leakage rate must be less than $0.02 \mathrm{ft}^{3} / \mathrm{min}$, to meet the acceptance criterion.

The following measures will also be implemented to ensure sample quality and to reduce any outside contamination or interference.

- The glassware will be cleaned and capped according to the method prior to sampling.

- The probe, connecting glassware, and impingers will be stoppered for return to the recovery area.

- Samples will be refrigerated after sampling.

- Reagent blank samples will be taken and analyzed.

- 10 percent QA samples (duplicates or spike analyses) will be analyzed

For the formaldehyde and ammonia samples, breakthrough determinations will be made. For the ammonia and formaldehyde sampling trains, the two-impinger set will be analyzed separately once daily for each test condition; all other two-impinger sets will be combined for one analysis. 


\section{A.5 Continuous Emissions Monitoring}

The CEM system analyzers will be calibrated before and after each test using a manufacturer's certified gas or Environics gas dilution analyzer. A leak check of the system will be performed before the initiation of sample analyses. Multi-point calibrations of the CEM system analyzers will be performed. A field audit will be performed on the Environics gas dilutions system according to EPA Method 205.

\section{A.6 Sample Tracking}

Numbered sample labels and chain-of-custody forms will be used to identify and track samples from the field to the laboratory. Each sample will be placed into an appropriate container, which will then labeled with the sample date and time, the sample location and site, the analytical method required, and the sample's unique identification number. Solution and filter blanks will be treated as separate samples and packaged appropriately. The sample number, the location and site, and the date and time will be noted on the corresponding chain-of-custody form. The field sample custody clerk retains responsibility for the samples until they are transferred to the laboratory. The chain-of-custody forms accompany the samples to the laboratory, where the laboratory sample custodian accepts responsibility for the samples. Before samples are shipped to the laboratory, the field sample custody clerk verifies the accuracy of the forms. The completed chain-of-custody forms will be appended.

\section{A.7 Emissions Sampling Test Matrices}

Continuous emissions monitoring will be performed throughout all tests for total $\mathrm{HC}, \mathrm{NO}_{\mathrm{x}}, \mathrm{O}_{2}$, $\mathrm{CO}$, and $\mathrm{CO}_{2}$. The sampling location will be either downstream of the PrOx or the exhaust burner as indicated in the test matrices below. The target loads for each sampling point are referenced to the maximum, or full, load that can be achieved by the reformer when operating in conjunction with the fuel cell.

To keep track of the various non-continuous samples collected during testing, a specific labeling convention will be used. The labeling convention will consist of the parameters indicated in Figure A-1.

Speciated hydrocarbon analysis will be performed from Summa canister "grab” samples collected during fuel processor testing using evacuated canisters. The grab samples will be collected once the system has reached a given load set point, as shown in Figures A-2 through A-5. Of the grab samples collected, a majority of the canisters will be analyzed for speciated hydrocarbon emissions. The remainder of the canisters will serve as duplicates to be used in the event that results are inconclusive or the primary samples do not arrive intact.

The sampling will occur in the order specified, with CEM sampling running continuously. Where possible, PM, formaldehyde, and ammonia sampling will take place over a 30-minute period at a given load. In the case of PM sampling, if an overly large pressure drop develops due to the PM collected on the filter, the exhaust flow will be diverted back to the normal exhaust pathway, and the stop time will be noted. In general, deviations from the plan will be recorded on the printed copy of the test matrix. 
In Figures A-2 through A-6, the final load set point represents minimum load, or "idle", operation and may actually occur at a different load point. These Runs will be repeated for each of the fuels to be tested.

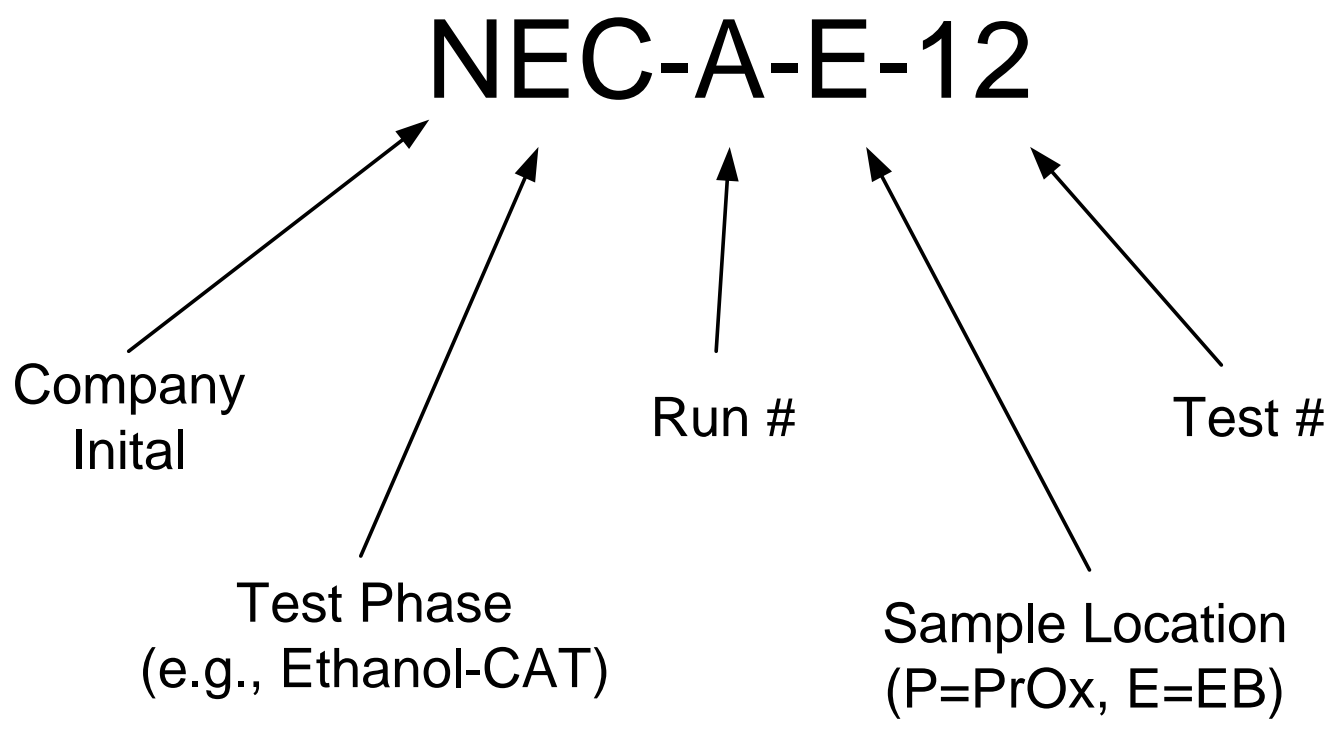

Figure A-1. Labeling Convention for the Non-continuous Emission Samples

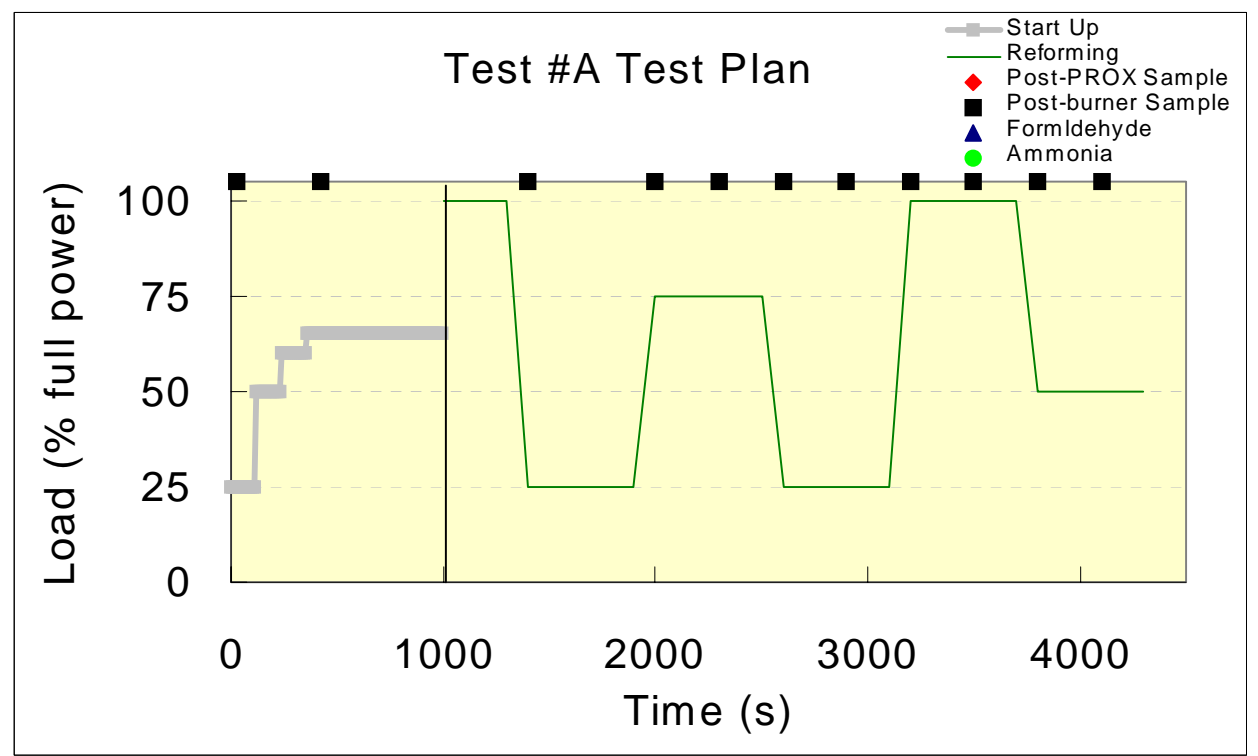

Figure A-2. Emissions Sampling Testing Plan - Run \#A: Grab Samples from Post-Burner Exhaust Stream 


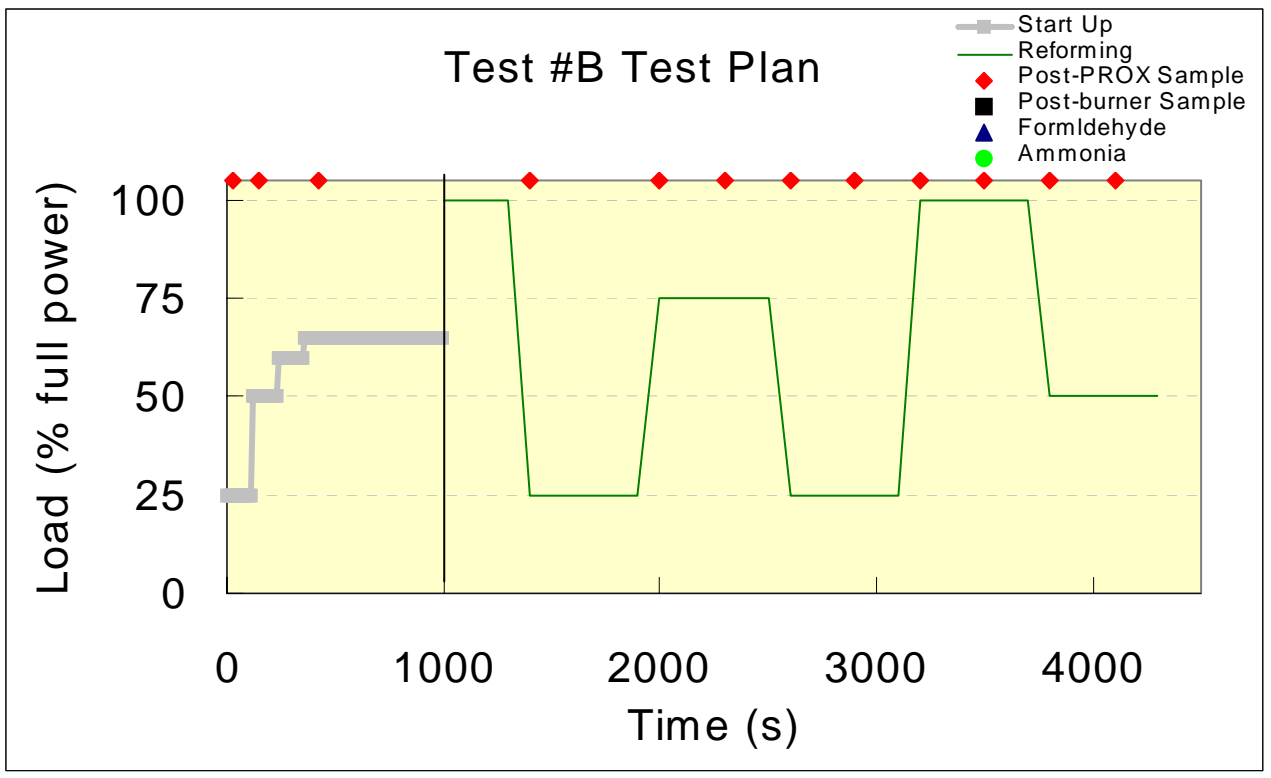

Figure A-3. Emissions Sampling Testing Plan - Run \#B: Grab Samples from Post-PrOx Exhaust Stream

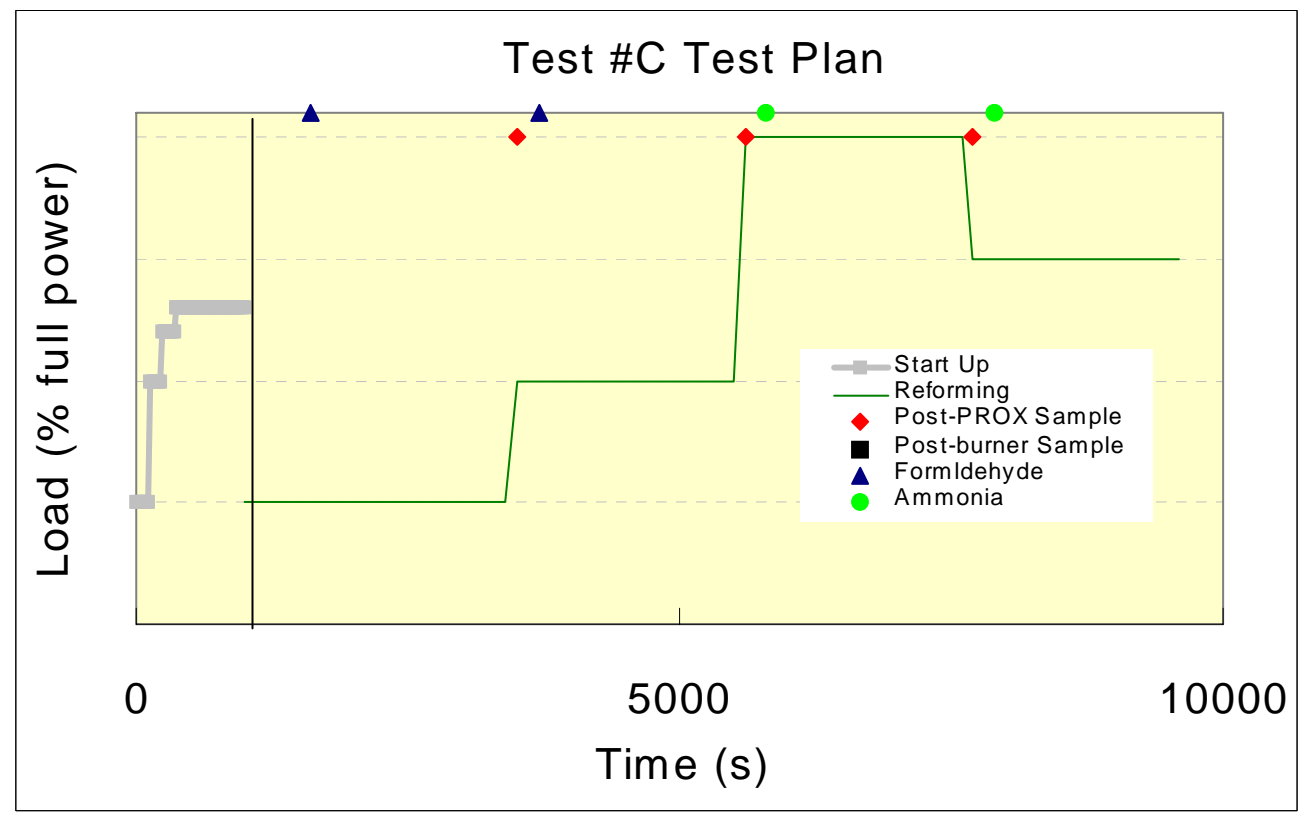

Figure A-4. Emissions Sampling Testing Plan - Run \#C: Formaldehyde and Ammonia Sampling from the Post-burner Exhaust Stream (with some Grab Samples) 


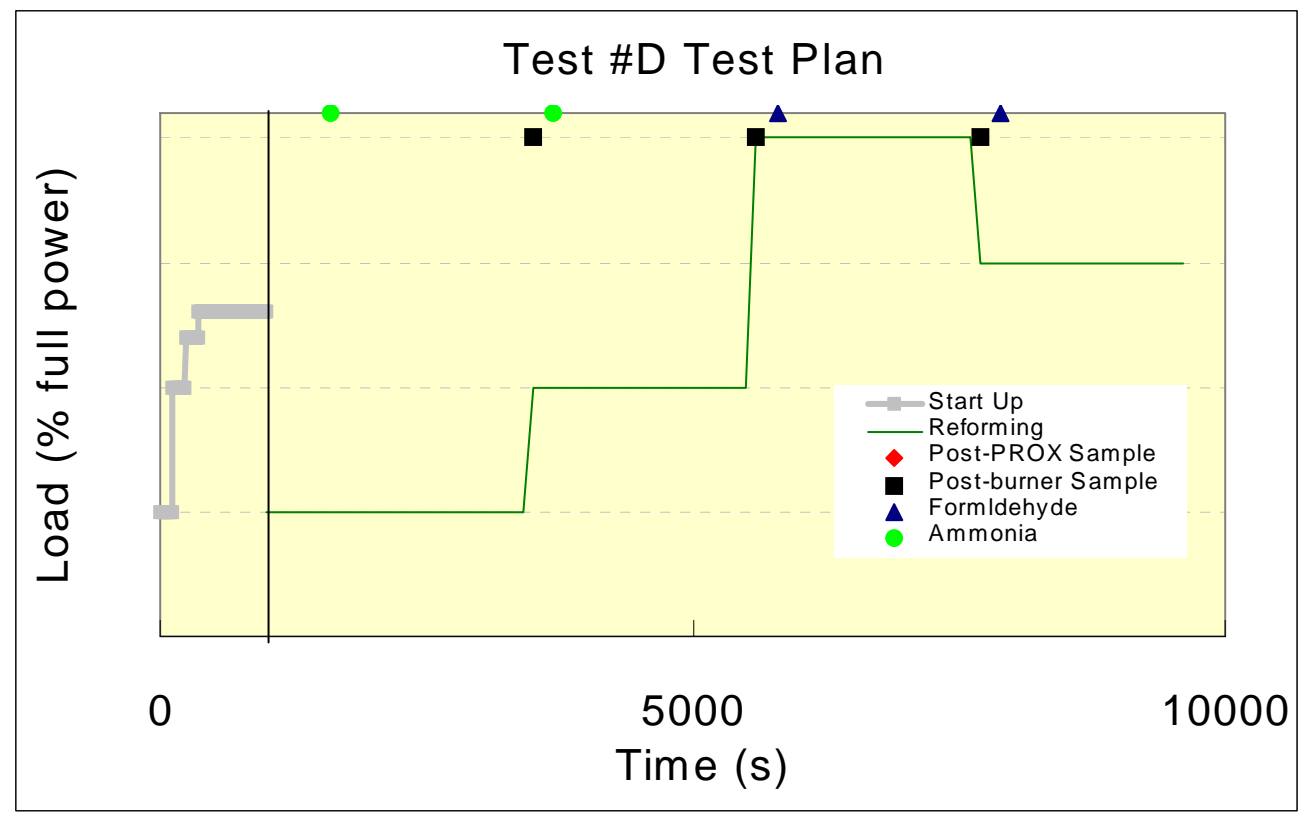

Figure A-5. Emissions Sampling Testing Plan - Run \#D: Formaldehyde and Ammonia Sampling from the Post-PrOx Exhaust Stream (with some Grab Samples)

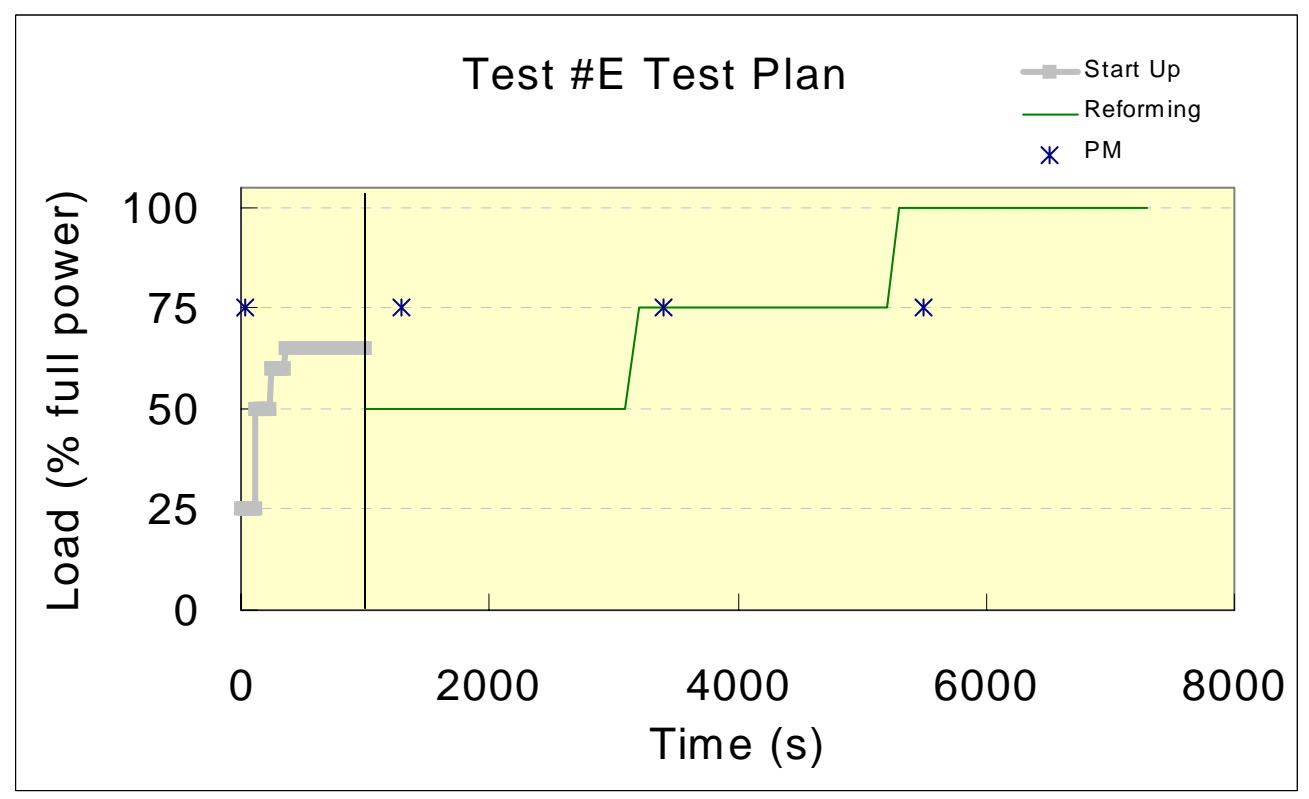

Figure A-6. Emissions Sampling Testing Plan - Run \#E: Particulate Matter Sampling from the Post-burner Exhaust Stream 


\section{A.8 Estimating Equivalence Ratio From Emissions Measurements}

In the absence of direct measures of the stoichiometry in the exhaust burner, the air/fuel ratio will be estimated based on emissions measurements. This estimation

In general, the combustion of a fuel in air is represented by the chemical equation:

$$
\begin{aligned}
& \mathrm{C}_{\mathrm{n}} \mathrm{H}_{\mathrm{m}} \mathrm{O}_{\mathrm{r}}+\frac{\mathrm{n}_{\mathrm{O} 2}}{\phi}\left(\mathrm{O}_{2}+3.773 \mathrm{~N}_{2}\right)=\mathrm{n}_{\mathrm{p}}\left(\mathrm{x}_{\mathrm{CaHb}} \mathrm{C}_{\mathrm{a}} \mathrm{H}_{\mathrm{b}}+\mathrm{x}_{\mathrm{CO}} \mathrm{CO}+\mathrm{x}_{\mathrm{CO} 2} \mathrm{CO}_{2}+\mathrm{x}_{\mathrm{O} 2} \mathrm{O}_{2}\right. \\
& \left.+\mathrm{x}_{\mathrm{N} 2} \mathrm{~N}_{2}+\mathrm{x}_{\mathrm{NO}} \mathrm{NO}+\mathrm{x}_{\mathrm{NO} 2} \mathrm{NO}_{2}+\mathrm{x}_{\mathrm{H} 2 \mathrm{O}} \mathrm{H}_{2} \mathrm{O}+\mathrm{x}_{\mathrm{H} 2} \mathrm{H}_{2}\right)
\end{aligned}
$$

where $\mathrm{n}_{\mathrm{O} 2}$ is the number of moles of $\mathrm{O}_{2}$ molecules, $\mathrm{n}_{\mathrm{p}}$ is the total number of moles of exhaust products, and $\mathrm{x}_{\mathrm{i}}$ is the mole fraction of the $\mathrm{i}^{\text {th }}$ component. In this study, concentrations of $\mathrm{CO}_{2}$, $\mathrm{CO}, \mathrm{O}_{2}, \mathrm{NO}_{\mathrm{x}}$, and unburned hydrocarbons (as $\mathrm{C}_{1}$, i.e., $\mathrm{x}_{\mathrm{CHb} / \mathrm{a}}$ ) will be measured directly using CEMS. Thus, in Eq. (A-1), the values of $\mathrm{x}_{\mathrm{CO}}, \mathrm{x}_{\mathrm{CO} 2}$, and $\mathrm{x}_{\mathrm{O} 2}$ will be explicitly available. Furthermore, since the fraction of exhaust that is $\mathrm{NO}_{\mathrm{x}}$ will be relatively small, the concentrations of $\mathrm{NO}$ and $\mathrm{NO}_{2}$ can be ignored with a negligible effect on calculating the air/fuel ratio.

Thus, based on the measurement equipment and assumptions used in this study, the following species balances result from Eq. (A-1):

Carbon balance:

$$
\mathrm{n}=\mathrm{n}_{\mathrm{p}}\left(\mathrm{a} \mathrm{x}_{\mathrm{CaHb}}+\mathrm{x}_{\mathrm{CO}}+\mathrm{x}_{\mathrm{CO} 2}\right)
$$

Hydrogen balance:

$$
\mathrm{m}=\mathrm{n}_{\mathrm{p}}\left(\mathrm{b} \mathrm{x}_{\mathrm{CaHb}}+2 \mathrm{x}_{\mathrm{H} 2 \mathrm{O}}+2 \mathrm{x}_{\mathrm{H} 2}\right)
$$

Oxygen balance:

$$
\mathrm{r}+\frac{2 \mathrm{n}_{\mathrm{O} 2}}{\phi}=\mathrm{n}_{\mathrm{p}}\left(\mathrm{x}_{\mathrm{CO}}+2 \mathrm{x}_{\mathrm{CO} 2}+2 \mathrm{x}_{\mathrm{O} 2}+\mathrm{x}_{\mathrm{H} 2 \mathrm{O}}\right)
$$

Nitrogen balance:

$$
\frac{7.546 \mathrm{n}_{\mathrm{O} 2}}{\phi}=\mathrm{n}_{\mathrm{p}}\left(2 \mathrm{x}_{\mathrm{N} 2}+\mathrm{x}_{\mathrm{NO}}\right)
$$

Furthermore, assuming a specific value for the water-gas reaction equilibrium constant, $\mathrm{CO}_{2}$, $\mathrm{CO}, \mathrm{H}_{2} \mathrm{O}$ and $\mathrm{H}_{2}$ concentrations are related through the expression:

$$
\frac{\mathrm{x}_{\mathrm{CO}} \mathrm{X}_{\mathrm{H} 2 \mathrm{O}}}{\mathrm{x}_{\mathrm{CO} 2} \mathrm{X}_{\mathrm{H} 2}}=\mathrm{K}
$$

where, following Spindt (SAE 650507) the value of K will be assumed to be 3.5 for this study. 
Since the $\mathrm{CO}, \mathrm{CO}_{2}, \mathrm{O}_{2}$, and $\mathrm{HC}$ measured at the TGC exit will be measured at the same background moisture (i.e., dry), Eq. (A-2) through (A-6) can be combined into an expression for the air/fuel ratio based on an oxygen balance. Specifically, from Eq. (A-1), the air/fuel ratio is expressed as:

$$
\frac{\text { Air }}{\text { Fuel }}=4.76 \frac{\mathrm{n}_{\mathrm{O} 2}}{\phi}
$$

From the oxygen balance in Eq. (4), $\mathrm{n}_{\mathrm{O} 2}$ can be expressed as:

$$
\mathrm{n}_{\mathrm{O} 2}=\phi \frac{\mathrm{n}_{\mathrm{p}}}{2}\left(\mathrm{x}_{\mathrm{CO}}+2 \mathrm{x}_{\mathrm{CO} 2}+2 \mathrm{x}_{\mathrm{O} 2}+\mathrm{x}_{\mathrm{H} 2 \mathrm{O}}\right)-\frac{\mathrm{r} \phi}{2}
$$

Combining Eq. (7) and (8) results in

$$
\frac{\text { Air }}{\text { Fuel }}=4.76 \mathrm{n}_{\mathrm{p}}\left(\frac{\mathrm{x}_{\mathrm{CO}}}{2}+\mathrm{x}_{\mathrm{CO} 2}+\mathrm{x}_{\mathrm{O} 2}+\frac{\mathrm{x}_{\mathrm{H} 2 \mathrm{O}}}{2}\right)-\frac{\mathrm{r}}{2}
$$

Since the unburned hydrocarbons are measured as $\mathrm{C}_{1}$ and it is assumed here that the composition of the unburned hydrocarbons is the same as that of the fuel, Eq. (A-2) can be rearranged and substituted into Eq. (A-9) such that

$$
\frac{\text { Air }}{\text { Fuel }}=4.76\left(\frac{\mathrm{x}_{\mathrm{co} / 2}+\mathrm{x}_{\mathrm{CO} 2}+\mathrm{x}_{\mathrm{O} 2}+{ }^{\mathrm{x}_{\mathrm{H} 2 \mathrm{O}} / 2}}{\mathrm{x}_{\mathrm{CaHb}}+\mathrm{x}_{\mathrm{CO}}+\mathrm{x}_{\mathrm{CO} 2}}\right)-\frac{\mathrm{r}}{2}
$$

Equation (A-10) expresses the air-fuel ratio on a volumetric basis. To express this ratio on a mass basis, the appropriate ratio of molecular weights must be included such that Eq. (A-10) becomes

$$
\frac{\text { Air }}{\text { Fuel }}=4.76 \frac{\mathrm{M}_{\mathrm{air}}}{\mathrm{M}_{\mathrm{f}}}\left(\frac{\mathrm{x}_{\mathrm{co} / 2}+\mathrm{x}_{\mathrm{CO} 2}+\mathrm{x}_{\mathrm{O} 2}+{ }^{\mathrm{x}_{\mathrm{H} 2} / 2} / 2}{\mathrm{x}_{\mathrm{CaHb}}+\mathrm{x}_{\mathrm{CO}}+\mathrm{x}_{\mathrm{CO} 2}}\right)-\frac{\mathrm{M}_{\mathrm{air}}}{\mathrm{M}_{\mathrm{f}}} \frac{\mathrm{r}}{2}
$$

where $\mathrm{M}_{\mathrm{air}}=28.96, \mathrm{M}_{\mathrm{f}}=12.01+1.008^{*} \mathrm{y}$ where $\mathrm{y}$ is the $\mathrm{HC}$ ratio of the fuel, and $\mathrm{x}_{\mathrm{CaHb}}$ is the mole fraction of hydrocarbon as $C_{1}$. For ease of computation, Eq. (A-11) may be rewritten as

$$
\frac{\text { Air }}{\text { Fuel }}=4.76 \frac{\mathrm{M}_{\mathrm{air}}}{\mathrm{M}_{\mathrm{f}}}\left(\frac{(\mathrm{CO}) / 2+\left(\mathrm{CO}_{2}\right)+\left(\mathrm{O}_{2}\right)+\left(\mathrm{H}_{2} \mathrm{O}\right) / 2}{(\mathrm{HC})+(\mathrm{CO})+\left(\mathrm{CO}_{2}\right)}\right)-100 \frac{\mathrm{M}_{\mathrm{air}}}{\mathrm{M}_{\mathrm{f}}} \frac{\mathrm{r}}{2}
$$

where ( ) denotes percent molar concentration.

Through Eq. (A-2), Eq. (A-3), and Eq. (A-6), the steam concentration in Eq. (A-12) is estimated through the expression in Eq. (A-13):

$$
\left(\mathrm{H}_{2} \mathrm{O}\right)=0.5 \mathrm{y} \frac{\left(\mathrm{CO}_{2}\right)+(\mathrm{CO})}{(\mathrm{CO}) /\left[\mathrm{K}\left(\mathrm{CO}_{2}\right)\right]+1}
$$


Again, $y$ is the HC ratio of the fuel. Finally, by combining Eq. (A-12) and (A-13), the air-fuel ratio is estimated from the exhaust emissions measurem

\section{A.9 Minimum Emission Detection Limits}

Based on the emission conversion methodology described in Section 3, it is possible to convert the minimum detection levels of the analyzers used in this study to estimated minimum detection levels on a gram/mile basis for a POX/PEMFC system operating over the FUDS. To perform this conversion, several aspects of such a POX/PEMFC system are assumed:

- The POX/PEMFC system is comprised of a $60 \mathrm{~kW}$ PEMFC and an appropriately sized reformer (i.e., there is no mismatch between the fuel cell stack and the reformer). Such an assumption results in a "worst-case" estimation of minimum detection limits because the exhaust flow rate in this configuration is greater than the exhaust flow rate in a configuration in which the reformer capacity exceeds the fuel cell stack size (i.e., $60 \mathrm{~kW}$ reformer and a 10 $\mathrm{kW}$ stack).

- For conditions in which the vehicle power demand exceeds the $6 \mathrm{~kW}$ minimum power output of the fuel cell, it is also assumed that the POX/PEMFC system follows the instantaneous load demand corresponding to the transient cycle (i.e., no power management strategy is assumed).

- For conditions in which the power demand is greater than zero but is less than $6 \mathrm{~kW}$, the load demand is assumed to be $6 \mathrm{~kW}$.

By applying the methodology outlined in Section 3 to the FUDS, the corresponding fueling rates are predicted for the system assumed here. These fueling rates (g fuel/s) are a function of the lower heating value (LHV) of the fuel that is being reformed into hydrogen. These estimated fueling rates are used to determine the minimum emissions levels ( $\mathrm{mg} / \mathrm{mi})$ that can be measured over the FUDS cycle with the analyzers to be used for the Nuvera tests.

The minimum detection limits of the analyzers that will be used to sample exhaust from the exhaust burner are listed in Table D-1. Assuming that the minimum detectable limit of each pollutant (with the exception of PM) ${ }^{21}$ is measured at each second in the FUDS cycle, the minimum emission level is determined as follows:

- Using an estimate of the exhaust flow rate $^{22}$, pollutant concentrations are converted from ppm to g/s as follows ${ }^{23}$ :

\footnotetext{
${ }^{21}$ The PM measurement is made over a given period of time. For the purpose of determining the minimum emission level of PM, it was assumed that the minimum detectable particulate mass was collected after the entire FUDS cycle. Therefore, the minimum emission level $(\mathrm{mg} / \mathrm{mi})$ was calculated as the ratio of the minimum detectable particulate mass to the number of miles in the FUDS cycle.

${ }^{22}$ At each second in the FUDS cycle, the fueling rate (g/s) was converted to exhaust flow rate (g/s), assuming that the TGC operates with a $\lambda=1.2$.

${ }^{23}$ The molecular weight of the exhaust was approximated as the molecular weight of air.
} 
Mass Poll. Rate $[\mathrm{g} / \mathrm{s}]=$ Poll. Conc. $[\mathrm{ppm}] * \mathrm{MW}_{\text {poll }} *$ Exh. Flow Rate $[\mathrm{g} / \mathrm{s}] /\left(\mathrm{MW}_{\mathrm{exh}} * 10^{6}\right)$

- The total mass of pollutant emitted (mg) is determined through integration over the entire FUDS cycle

- The emission level is determined by dividing by the number of miles in the FUDS cycle (7.45 mi).

These minimum emission levels are listed in Table D-1. For the purpose of comparison, the California SULEV emission standard that corresponds to each pollutant is also listed in the table. The results shown in this table lead to two conclusions:

1. The minimum emission levels associated with the analyzers to be used in the Nuvera tests are well below the California SULEV standards.

2. The minimum emission levels of the pollutants will be sensitive to the fuel used in the tests.

Table A-1. Minimum Detectable Emission Levels Over the FUDS Cycle

\begin{tabular}{|c|l|c|c|c|}
\hline $\begin{array}{c}\text { Fuel } \\
\text { Type }\end{array}$ & \multicolumn{1}{|c|}{ Species } & $\begin{array}{c}\text { Minimum } \\
\text { Detection Limit }\end{array}$ & $\begin{array}{c}\text { Equivalent } \\
\text { Detection Limit }\end{array}$ & $\begin{array}{c}\text { California SULEV } \\
\text { Standard }\end{array}$ \\
\hline \hline \multirow{3}{*}{$\overline{0}$} & $\mathrm{NO}_{\mathrm{x}}$ & $0.1 \mathrm{ppm}$ & $0.17 \mathrm{mg} / \mathrm{mi}$ & $20 \mathrm{mg} / \mathrm{mi}$ \\
\cline { 2 - 5 } & $\mathrm{CO}$ & $1 \mathrm{ppm}$ & $1.02 \mathrm{mg} / \mathrm{mi}$ & $1000 \mathrm{mg} / \mathrm{mi}$ \\
\cline { 2 - 5 }$\overline{\mathrm{\sigma}}$ & $\mathrm{THC}^{*}$ & $0.2 \mathrm{ppm}$ & $0.36 \mathrm{mg} / \mathrm{mi}$ & $\mathrm{NA}$ \\
\cline { 2 - 5 } & $\mathrm{NMOG}^{* *}$ & $\sim 0.01 \mathrm{ppm}$ & $\sim 0.018 \mathrm{mg} / \mathrm{mi}$ & $10 \mathrm{mg} / \mathrm{mi}$ \\
\cline { 2 - 5 } & $\mathrm{PM}$ & $0.1 \mathrm{mg}$ & $0.013 \mathrm{mg} / \mathrm{mi}$ & $10 \mathrm{mg} / \mathrm{mi}$ \\
\hline
\end{tabular}

* Molecular weight assumed to be $50 \mathrm{~g} / \mathrm{mol}$

** NMOG is assumed to be $0.05^{\star} \mathrm{THC}$ based on prior testing

\section{A.10 Fuel Properties}

Two of the following fuels of interest will be used during the Nuvera fuel processor tests: gasoline, natural gas (methane), methanol, or ethanol. The properties of these fuels are listed in Table A-1 below.

The listed properties are a priori estimates; actual properties will be verified at the time of the experiment. 
Table A-2. Fuel Properties

\begin{tabular}{|l|c|c|c|c|}
\hline \multicolumn{1}{|c|}{ Parameter } & Gasoline & Natural Gas & Methanol & Ethanol \\
\hline LHV (MJ/kg) & 44 & 45 & 20 & 26.9 \\
Density & 0.75 & $\sim 0.79$ & 0.792 & 0.785 \\
Molecular Weight & 110 & 18 & 32.04 & 46.07 \\
H/C Ratio & 1.87 & 3.8 & 4 & 3 \\
Stoichiometric A/F (mass) & 14.6 & 14.5 & 6.47 & 9.0 \\
Stoichiometric A/F (molar) & 55.69 & 9.0 & 7.19 & 14.4 \\
Carbon atoms/molecule & 8 & na & 1 & 2 \\
\hline
\end{tabular}




\section{Appendix B. DOE Technical Targets}

Tables B-1 through B-3 list the DOE technical targets for PEM fuel cell stack systems, fuelflexible fuel processors, and integrated fuel cell power systems operating on gasoline. Target values listed in these tables represent a self-consistent set and must be achieved simultaneously. Targets for 2010 are R\&D milestones for the purpose of measuring progress, not necessarily the targets required for successful commercialization of the technology. Table B-4 lists the DOE technical targets for integrated fuel cell power systems running on direct hydrogen. Table B-5 shows the technical targets for on-board hydrogen storage, and Table B-6 lists the technical targets for off-board hydrogen production and dispensing infrastructure. Tables B-7 through B-9 list technical targets for fuel cell stack and fuel processor components. All targets were developed with industry through preliminary vehicle system analyses and will be refined further as the technology matures and power system trade-offs are identified. Targets for hydrocarbonbased systems are based on operation with reformulated gasoline containing an average of 30 ppm sulfur (80 ppm maximum); except for the hydrogen storage targets in Table B-5, all power target values indicate electric power $\left(\mathrm{W}_{\mathrm{e}}\right)$.

The process for developing fuels for on-board fuel-flexible fuel processing will focus on identifying fuels that will enable the overall fuel cell power system, to meet the technical targets reflected in Table B-3. The fuels-specific technical targets for fuels for on-board fuel-flexible fuel processing include a retail price that is less than a 5 percent increase over premium grade gasoline, and health and safety impacts that are equal to or improved relative to conventional gasoline (by model analysis). 
Table B-1. Technical targets: fuel cell stack systems operating on hydrogen-containing fuel from a fuel processor (gasoline reformate) in $50 \mathrm{kWe}$ (net) fuel cell systems

(Excludes fuel processing/delivery system)

(Includes fuel cell ancillaries: thermal, water, air management systems)

All targets must be achieved simultaneously and are consistent with those of FreedomCAR

\begin{tabular}{|c|c|c|c|c|}
\hline \multirow[b]{2}{*}{ Characteristics } & \multirow[b]{2}{*}{ Units } & \multicolumn{3}{|c|}{ Calendar Year } \\
\hline & & $\begin{array}{l}2001 \\
\text { Status }\end{array}$ & 2005 & 2010 \\
\hline Stack system power density ${ }^{a, b}$ & $\mathrm{~W} / \mathrm{L}$ & 200 & 400 & 550 \\
\hline Stack system specific power & W/kg & 200 & 400 & 550 \\
\hline Stack system efficiency ${ }^{c} @ 25 \%$ of rated power & $\%$ & 45 & 50 & 55 \\
\hline Stack system efficiency $^{c} @$ rated power & $\%$ & 40 & 42 & 44 \\
\hline Precious metal loading $^{d}$ & g/rated kW & 2.0 & 0.6 & 0.2 \\
\hline Cost $^{e}$ & $\$ / \mathrm{kW}$ & 200 & 100 & 35 \\
\hline Durability $^{f}$ & hours & $1000^{g}$ & $>2000^{h}$ & $>5000^{i}$ \\
\hline $\begin{array}{l}\text { Transient response (time for } 10 \text { to } 90 \% \text { of rated } \\
\text { power) }\end{array}$ & sec & 3 & 2 & 1 \\
\hline $\begin{array}{l}\text { Cold startup time to rated power } \\
\qquad-20^{\circ} \mathrm{C} \text { ambient temperature } \\
@+20^{\circ} \mathrm{C} \text { ambient temperature }\end{array}$ & $\begin{array}{l}\min \\
\min \end{array}$ & $\begin{array}{l}2 \\
1\end{array}$ & $\begin{array}{c}1 \\
0.5\end{array}$ & $\begin{array}{c}0.5 \\
0.25\end{array}$ \\
\hline Survivability ${ }^{j}$ & C & -20 & -30 & -40 \\
\hline $\begin{array}{l}\text { CO tolerance }{ }^{k} \\
\text { steady state (with } 2 \% \text { maximum air bleed) } \\
\text { transient }\end{array}$ & $\begin{array}{l}\text { ppm } \\
\text { ppm }\end{array}$ & $\begin{array}{c}50 \\
100\end{array}$ & $\begin{array}{l}500 \\
500\end{array}$ & $\begin{array}{c}500 \\
1000\end{array}$ \\
\hline
\end{tabular}

${ }^{a}$ Power refers to net power (i.e., stack power minus auxiliary power requirements).

${ }^{b}$ Volume is "box" volume, including dead space, and is defined as the water-displaced volume times 1.5 (packaging factor). Power density includes ancillaries (sensors, controllers, electronics, radiator, compressor, expander, and air, thermal and water management) for stand alone operation.

${ }^{c}$ Ratio of output DC energy to lower heating value of hydrogen-rich fuel stream (includes converter for $300 \mathrm{~V}$ bus); ratio of rated power to $25 \%$ of rated power efficiencies unchanged, assuming continued proportional reduction in stack efficiency at higher current and proportional increase in compressor efficiency at higher flow rates.

${ }^{d}$ Equivalent total precious metal loading (anode+cathode): $0.1 \mathrm{mg} / \mathrm{cm}^{2}$ by 2010 at rated power. Precious metal target based on cost target of $<\$ 3 / \mathrm{kW}$ precious metals in MEA [@ $\$ 450 /$ troy ounce $(\$ 15 / \mathrm{g}),<0.2 \mathrm{~g} / \mathrm{kW}]$

e High-volume production: 500,000 units per year.

${ }^{f}$ Performance targets must be achieved at the conclusion of the durability period; durability includes tolerance to $\mathrm{CO}, \mathrm{H}_{2} \mathrm{~S}$ and $\mathrm{NH}_{3}$ impurities.

${ }^{g}$ Continuous operation (pertains to full power spectrum).

${ }^{h}$ Includes thermal cycling.

I Includes thermal and realistic driving cycles.

$j$ Performance targets must be achieved at the end of 8-hour cold-soak at temperature.

${ }^{k} \mathrm{CO}$ tolerance requirements assume capability of fuel processor to reduce $\mathrm{CO}$. Targets for the stack $\mathrm{CO}$ tolerance are subject to trade-offs between reducing $\mathrm{CO}$ in the fuel processor and enhancing $\mathrm{CO}$ tolerance in the stack. It is assumed that $\mathrm{H}_{2} \mathrm{~S}$ is removed in the fuel processor. 
Table B-2. Technical targets: fuel processors ${ }^{a}$ to generate hydrogen-containing fuel gas from reformulated gasoline containing $30 \mathrm{ppm}$ sulfur, average, for $50 \mathrm{kWe}$ (net) fuel cell systems

(Excludes fuel storage; includes controls, shift reactors, CO cleanup, heat exchangers) All targets must be achieved simultaneously and are consistent with those of FreedomCAR

\begin{tabular}{|c|c|c|c|c|}
\hline \multirow[b]{2}{*}{ Characteristics } & \multirow[b]{2}{*}{ Units } & \multicolumn{3}{|c|}{ Calendar Year } \\
\hline & & $\begin{array}{c}2001 \\
\text { Status }^{b}\end{array}$ & 2005 & 2010 \\
\hline Energy efficiency $^{c}$ & $\%$ & 78 & 78 & 80 \\
\hline Power density & W/L & 500 & 700 & 800 \\
\hline Specific power & W/kg & 450 & 700 & 800 \\
\hline $\operatorname{Cost}^{d}$ & $\$ / \mathrm{kW}$ & 85 & 25 & 10 \\
\hline $\begin{array}{l}\text { Cold startup time to maximum power } \\
@-20^{\circ} \mathrm{C} \text { ambient temperature } \\
@+20^{\circ} \mathrm{C} \text { ambient temperature }\end{array}$ & $\begin{array}{l}\min \\
\min \end{array}$ & $\begin{array}{l}\text { TBD } \\
<10\end{array}$ & $\begin{array}{l}2.0 \\
<1\end{array}$ & $\begin{array}{c}1.0 \\
<0.5\end{array}$ \\
\hline Transient response (time for 10 to $90 \%$ power) & sec & 15 & 5 & 1 \\
\hline Emissions $^{e}$ & & $\begin{array}{c}<\text { Tier } 2 \\
\text { Bin } 5\end{array}$ & $\begin{array}{c}<\text { Tier } 2 \\
\text { Bin } 5\end{array}$ & $\begin{array}{c}<\text { Tier } 2 \\
\text { Bin } 5\end{array}$ \\
\hline Durability $^{f}$ & hours & $1000^{g}$ & $4000^{h}$ & $5000^{i}$ \\
\hline Survivability ${ }^{j}$ & C & TBD & -30 & -40 \\
\hline $\begin{array}{l}\text { CO content in product stream } \\
\text { steady state } \\
\text { transient }\end{array}$ & $\begin{array}{l}\text { ppm } \\
\text { ppm }\end{array}$ & $\begin{array}{c}10 \\
100\end{array}$ & $\begin{array}{c}10 \\
100\end{array}$ & $\begin{array}{c}10 \\
100\end{array}$ \\
\hline $\mathrm{H}_{2} \mathrm{~S}$ content in product stream & $\mathrm{ppb}$ & $<200$ & $<50$ & $<10$ \\
\hline $\mathrm{NH}_{3}$ content in product stream & ppm & $<10$ & $<0.5$ & $<0.1$ \\
\hline
\end{tabular}

${ }^{a}$ With catalyst system suitable for use in vehicles.

${ }^{b}$ Projected status for system to be delivered in late $2002: 80 \%$ efficiency, $900 \mathrm{~W} / \mathrm{L}, 550 \mathrm{~W} / \mathrm{kg}$.

${ }^{c}$ Fuel processor efficiency $=$ total fuel cell system efficiency/fuel cell stack system efficiency, where total fuel cell system efficiency accounts for thermal integration. For purposes of testing fuelprocessor-only systems, the efficiency can be estimated by measuring the derated heating value efficiency (lower heating value of $\mathrm{H}_{2} \quad 0.95$ / lower heating value of the fuel in) where the derating factor represents parasitic system power losses attributable to the fuel processor.

${ }^{d}$ High-volume production: 500,000 units per year.

e $0.07 \mathrm{~g} / \mathrm{mile} \mathrm{NO}_{\mathrm{x}}$ and $0.01 \mathrm{~g} / \mathrm{mile} \mathrm{PM}$ (particulate matter).

${ }^{f}$ Time between catalyst and major component replacement; performance targets must be achieved at the end of the durability period.

${ }^{g}$ Continuous operation.

${ }^{h}$ Includes thermal cycling.

1 Includes thermal and realistic driving cycles.

$j$ Performance targets must be achieved at the end of an 8-hour cold-soak at specified temperature.

${ }^{k}$ Dependent on stack development (CO tolerance) progress. 
Table B-3. Technical targets: 50 kWe (net) integrated fuel cell power systems operating on Tier 2 gasoline containing $30 \mathrm{ppm}$ sulfur, average

(Including fuel processor, stack, auxiliaries)

(Excluding gasoline tank and vehicle traction electronics)

All targets must be achieved simultaneously and are consistent with those of FreedomCAR

\begin{tabular}{|c|c|c|c|c|}
\hline \multirow[b]{2}{*}{ Characteristics } & \multirow[b]{2}{*}{ Units } & \multicolumn{3}{|c|}{ Calendar Uear } \\
\hline & & $\begin{array}{c}2001 \\
\text { Status } \\
\end{array}$ & 2005 & 2010 \\
\hline Energy efficiency $^{a} @ 25 \%$ of rated power & $\%$ & 34 & 40 & 45 \\
\hline Energy efficiency @ rated power & $\%$ & 31 & 33 & 35 \\
\hline Power density & W/L & 140 & 250 & 325 \\
\hline Specific power & W/kg & 140 & 250 & 325 \\
\hline Cost $^{b}$ & $\$ / \mathrm{kW}$ & 300 & 125 & 45 \\
\hline Transient response (time from 10 to $90 \%$ power) & $\mathrm{sec}$ & 15 & 5 & 1 \\
\hline $\begin{array}{l}\text { Cold startup time to rated power } \\
\qquad-20^{\circ} \mathrm{C} \text { ambient temperature } \\
@+20^{\circ} \mathrm{C} \text { ambient temperature }\end{array}$ & $\begin{array}{l}\min \\
\min \end{array}$ & $\begin{array}{l}\text { TBD } \\
<10\end{array}$ & $\begin{array}{l}2 \\
1\end{array}$ & $\begin{array}{c}1 \\
<0.5\end{array}$ \\
\hline Survivability $^{c}$ & C & TBD & -30 & -40 \\
\hline Emissions $^{d}$ & & $\begin{array}{l}<\text { Tier } 2 \\
\text { Bin } 5^{e}\end{array}$ & $\begin{array}{l}<\text { Tier } 2 \\
\text { Bin } 5^{e}\end{array}$ & $\begin{array}{l}<\text { Tier } 2 \\
\text { Bin } 5^{e}\end{array}$ \\
\hline Durability $^{f}$ & hours & $1000^{g}$ & $2000^{h}$ & $5000^{i}$ \\
\hline Greenhouse Gases & \multicolumn{4}{|c|}{$\begin{array}{l}\text { One-third reduction compared with } \\
\text { conventional SI-IC engines in similar type } \\
\text { vehicles }\end{array}$} \\
\hline
\end{tabular}

${ }^{a}$ Ratio of dc output energy to the lower heating value of the input fuel (gasoline).

${ }^{b}$ Includes projected cost advantage of high-volume production $(500,000$ units per year) and includes cost for assembling/integrating the fuel cell system and fuel processor.

${ }^{c}$ Achieve performance targets at 8-hour cold-soak at temperature.

${ }^{d}$ Emissions levels will comply with emissions regulations projected to be in place when the technology is available for market introduction.

$0.07 \mathrm{NO}_{\mathrm{x}} \mathrm{g} / \mathrm{mile}$ and $0.01 \mathrm{PM} \mathrm{g/mile}$.

${ }^{f}$ Performance targets must be achieved at the end of the durability time period.

${ }^{g}$ Continuous operation.

${ }^{h}$ Includes thermal cycling.

Includes thermal and realistic drive cycles. 
Table B-4. Technical targets: $50 \mathrm{kWe}$ (net) integrated fuel cell power systems operating on direct hydrogen ${ }^{a}$

All targets must be achieved simultaneously and are consistent with those of FreedomCAR

\begin{tabular}{|c|c|c|c|c|}
\hline \multirow[b]{2}{*}{ Characteristics } & \multirow[b]{2}{*}{ Units } & \multicolumn{3}{|c|}{ Calendar Year } \\
\hline & & $\begin{array}{l}2001 \\
\text { Status }\end{array}$ & 2005 & 2010 \\
\hline Energy efficiency $^{b} @$ @ 25\% of rated power & $\%$ & 59 & 60 & 60 \\
\hline Energy efficiency @ rated power & $\%$ & 50 & 50 & 50 \\
\hline $\begin{array}{l}\text { Power density } \\
\text { excluding } \mathrm{H}_{2} \text { storage } \\
\text { including } \mathrm{H}_{2} \text { storage }\end{array}$ & $\begin{array}{l}W / L \\
W / L\end{array}$ & $\begin{array}{l}400 \\
\text { TBD }\end{array}$ & $\begin{array}{l}500 \\
150\end{array}$ & $\begin{array}{l}650 \\
220\end{array}$ \\
\hline $\begin{array}{l}\text { Specific power } \\
\text { excluding } \mathrm{H}_{2} \text { storage } \\
\text { including } \mathrm{H}_{2} \text { storage }\end{array}$ & $\begin{array}{l}\text { W/kg } \\
\text { W/kg }\end{array}$ & $\begin{array}{l}400 \\
\text { TBD }\end{array}$ & $\begin{array}{l}500 \\
250\end{array}$ & $\begin{array}{l}650 \\
325\end{array}$ \\
\hline Cost $^{c}$ (including $\mathrm{H}_{2}$ storage) & $\$ / \mathrm{kW}$ & 200 & 125 & 45 \\
\hline $\begin{array}{l}\text { Transient response (time from } 10 \text { to } 90 \% \text { of rated } \\
\text { power) }\end{array}$ & sec & 3 & 2 & 1 \\
\hline $\begin{array}{l}\text { Cold startup time to maximum power } \\
\qquad @-20^{\circ} \mathrm{C} \text { ambient temperature } \\
@+20^{\circ} \mathrm{C} \text { ambient temperature }\end{array}$ & $\begin{array}{l}\mathrm{sec} \\
\mathrm{sec}\end{array}$ & $\begin{array}{c}120 \\
60\end{array}$ & $\begin{array}{l}60 \\
30\end{array}$ & $\begin{array}{l}30 \\
15\end{array}$ \\
\hline Emissions & & Zero & Zero & Zero \\
\hline Durability $^{d}$ & hours & 1000 & $2000^{e}$ & $5000^{f}$ \\
\hline Survivability $^{g}$ & C & -20 & -30 & -40 \\
\hline
\end{tabular}

${ }^{a}$ Targets are based on hydrogen storage targets in an aerodynamic $2500-\mathrm{lb}$ vehicle.

${ }^{b}$ Ratio of DC output energy to the lower heating value of the input fuel (hydrogen).

${ }^{c}$ Includes projected cost advantage of high-volume production (500,000 units per year).

${ }^{d}$ Performance targets must be achieved at the end of the durability time period.

${ }^{e}$ Includes thermal cycling.

${ }^{f}$ Includes thermal and realistic drive cycles.

${ }^{g}$ Achieve performance targets at 8-hour cold-soak at temperature. 
Table B-5. Technical targets for on-board hydrogen storage ${ }^{a, b}$ subsystem

\begin{tabular}{|c|c|c|c|c|}
\hline Characteristic & Units & Target & $\begin{array}{c}2001 \text { Status } \\
\text { Physical } \\
\text { storage }^{c}\end{array}$ & $\begin{array}{c}2001 \text { Status } \\
\text { Chemical } \\
\text { storage }^{d}\end{array}$ \\
\hline Storage capacity $^{e}$ & wt\% & 6 & 5.2 & 3.4 \\
\hline $\begin{array}{l}\text { Recoverable usable } \\
\text { amount }^{f}\end{array}$ & $\%$ & 90 & 99.7 & $>90$ \\
\hline Energy density ${ }^{g}$ & $\mathrm{Wh} / \mathrm{L}^{h}$ & $1100^{h}$ & 813 & 1300 \\
\hline Specific energy ${ }^{i}$ & $\mathrm{Wh} / \mathrm{kg}^{h}$ & 2000 & 1745 & 1080 \\
\hline Cost $^{j}$ & $\$ / \mathrm{kWh}$ & 5 & $50^{k}$ & $18^{\prime}$ \\
\hline Cycle life & cycles & 500 & $>500$ & $20-50$ \\
\hline Operating temperature $^{m}$ & ${ }^{\circ} \mathrm{C}$ & $-40^{\circ}$ to $+50^{\circ} \mathrm{C}$ & $-40^{\circ}$ to $+50^{\circ} \mathrm{C}$ & $20^{\circ} \mathrm{C}$ to $50^{\circ} \mathrm{C}$ \\
\hline $\begin{array}{l}\text { Startup time to full flow } \\
@+20^{\circ} \mathrm{C} \\
@-20^{\circ} \mathrm{C}\end{array}$ & $\begin{array}{l}\mathrm{sec} \\
\mathrm{sec}\end{array}$ & $\begin{array}{l}15 \\
30\end{array}$ & $\begin{array}{l}<1 \\
\text { TBD }\end{array}$ & $\begin{array}{l}<15 \\
\text { TBD }\end{array}$ \\
\hline Refueling time & $\min$ & $<5$ & TBD & TBD \\
\hline Hydrogen loss & scc/hour/L & $<1.0$ & $<1.0$ & $<1.0$ \\
\hline
\end{tabular}

a Based on lower heating value of hydrogen; includes both physical and chemical methods of hydrogen storage; enables greater than 300-mile range, based on an aerodynamic, 2500-lb vehicle.

$b$ R\&D carried out in collaboration with DOE Hydrogen Program.

$c$ Includes compressed gas and cryogenic liquid tanks.

$d$ Projected from laboratory-scale $(100 \mathrm{~g})$ test beds and proposed system designs.

e Weight percent $\mathrm{H}_{2}$ is the weight of $\mathrm{H}_{2}$ divided by the weight of $\left(\mathrm{H}_{2}+\operatorname{tank}\right)$.

$f$ Recoverable stored hydrogen, e.g. in a $100-\mathrm{kg} \mathrm{H}_{2}$ storage system containing $6 \mathrm{~kg}$ of stored hydrogen, at least $5.4 \mathrm{~kg}$ of useful hydrogen must be recoverable.

$g$ Based on $5 \mathrm{~kg}$ hydrogen for $>300$ mile range at 10,000 psia (volume of stored hydrogen is $135 \mathrm{~L}$ ). Allowing for $10 \%$ containment volume, system volume is $150 \mathrm{~L}$. .

$h$ Watts thermal.

I Specific energy is the lower heating value energy of $\mathrm{H}_{2}$ contained, divided by the weight of $\left(\mathrm{H}_{2}+\right.$ tank).

j Based on high-volume production of 500,000 units per year.

$k$ Based on individual tanks.

1 Projected hydride material cost only; based on 100-200 kg alanate production.

$m$ Hydrogen storage system must provide hydrogen to the fuel cell at these ambient temperatures. 
Table B-6 Technical targets for off-board hydrogen production and dispensing infrastructure

\begin{tabular}{|c|c|c|c|c|c|}
\hline Component & $\begin{array}{c}\text { Characteristic } \\
\text { (LHV Basis) }\end{array}$ & Units & $\begin{array}{l}\text { Current } \\
\text { Status }^{a}\end{array}$ & 2005 & 2010 \\
\hline Reforming & $\begin{array}{l}\text { Cost } \\
\text { WTW GHGs } \\
\text { Primary Energy Eff. }\end{array}$ & $\begin{array}{l}\$ / G J H_{2} \\
\mathrm{~g} / \mathrm{km} \\
\%(\mathrm{LHV})\end{array}$ & $\begin{array}{l}9.9 \\
75 \\
80^{c} \\
\end{array}$ & $\begin{array}{l}8.8 \\
70 \\
82 \\
\end{array}$ & $\begin{array}{c}7.7^{b} \\
65 \\
85 \\
\end{array}$ \\
\hline Purification & $\begin{array}{l}\text { Cost } \\
\text { WTW GHGs } \\
\text { Primary Energy Eff. }\end{array}$ & $\begin{array}{l}\$ / G J H_{2} \\
\mathrm{~g} / \mathrm{km} \\
\%(\mathrm{LHV})\end{array}$ & $\begin{array}{c}0.56 \\
1.1 \\
75^{f}\end{array}$ & $\begin{array}{c}0.56 \\
1.1 \\
82\end{array}$ & $\begin{array}{c}0.56^{d} \\
1.1 \\
90\end{array}$ \\
\hline Compression & $\begin{array}{l}\text { Cost } \\
\text { WTW GHGs } \\
\text { Primary Energy Eff. }\end{array}$ & $\begin{array}{l}\$ / G J H_{2} \\
\mathrm{~g} / \mathrm{km} \\
\%(\mathrm{LHV})\end{array}$ & $\begin{array}{c}2.6 \\
14 \\
82^{h} \\
\end{array}$ & $\begin{array}{l}2.3 \\
11 \\
85 \\
\end{array}$ & $\begin{array}{c}2.0^{g} \\
8 \\
88 \\
\end{array}$ \\
\hline $\begin{array}{l}\text { Storage \& } \\
\text { Dispensing }\end{array}$ & $\begin{array}{l}\text { Cost } \\
\text { WTW GHGs } \\
\text { Primary Energy Eff. }\end{array}$ & $\begin{array}{l}\$ / G J H_{2} \\
\mathrm{~g} / \mathrm{km} \\
\%(\mathrm{LHV})\end{array}$ & $\begin{array}{c}2.7^{i} \\
0 \\
100^{k}\end{array}$ & $\begin{array}{c}2.7 \\
0 \\
100\end{array}$ & $\begin{array}{c}2.7^{j} \\
0 \\
100\end{array}$ \\
\hline Total & $\begin{array}{l}\text { Cost }^{\prime} \\
\text { WTW GHGs } \\
\text { Primary Energy Eff. }\end{array}$ & $\begin{array}{l}\$ / G J H_{2} \\
\mathrm{~g} / \mathrm{km} \\
\%(\mathrm{LHV})\end{array}$ & $\begin{array}{c}19.2 \\
90 \\
62\end{array}$ & $\begin{array}{c}17.2 \\
82 \\
68\end{array}$ & $\begin{array}{c}16.2^{m} \\
75 \\
75\end{array}$ \\
\hline
\end{tabular}

Notes: Well-to-wheel greenhouse gas (WTW GHG) emissions are weighted by their global warming potential. Assumes 84-mpeg fuel economy in a direct hydrogen FCV and on-site power from the US average grid mix. Primary energy efficiency is defined as Hydrogen Output LHV / Primary Energy Input LHV of the process step. Primary energy associated with on-site power use assumes a 35\% production and transmission efficiency penalty (typical US grid mix).

a Assumes state-of-the-art technology that is feasible but not necessarily available in a complete system today. This assumption is consistent with the automotive fuel cell performance target assumptions.

B Assumes energy cost reductions by way of higher efficiency and a $50 \%$ equipment cost reduction from the current scenario. Small-scale reformers are assumed to come down significantly in price with projected advances in materials and designs.

C Assuming a steam methane reformer operating at $10 \mathrm{~atm}$.

D Assumes no equipment cost reduction from the current scenario. Conventional equipment (PSAs) will not likely come down significantly in price, especially with higher efficiency requirements. Advanced technologies may provide higher efficiencies, but are unlikely to be cheaper.

E Assumes $100 \%$ of the purification purge stream (primarily $\mathrm{CO} 2, \mathrm{H} 2, \mathrm{CH} 4$, and $\mathrm{CO}$ ) is recycled to the production step, where the purge stream is burned to generate heat for the reforming process. There may be some additional purification emissions in other system configurations, but the total sum of emissions from the production and purification steps will remain the same.

F Assuming a small-scale PSA system operating at reformer outlet pressure.

$G$ Assumes energy cost reductions by way of higher efficiency but no equipment cost reduction from the current scenario. Conventional equipment (gas compressors) will not likely come down significantly in price, especially with higher efficiency requirements. Advanced technologies may provide higher efficiencies, but are unlikely to be cheaper.

$\mathrm{H}$ Assuming conventional compressors are used from the PSA outlet pressure to 3600-psi maximum on-site storage pressure and accumulator-type compressors are used from the storage pressure to 5000 psi on-board storage.

Based on 3600-psi on-site gas storage.

$\mathrm{J}$ Assumes no equipment cost reduction from the current scenario. Conventional equipment (high-pressure gas storage tanks) will not likely come down significantly in price. Advanced technologies may provide higher overall efficiencies, but are unlikely to be cheaper.

$\mathrm{K}$ Assuming high-pressure gas storage with no leaks during storage or dispensing.

L Includes operation, site prep, and central control costs.

M Costs are based on a hydrogen fueling station serving 300 vehicles per day $(\sim 10,000$ std m3 per day) with onsite production. Capital equipment costs assume mature production volumes of 100 units per year. Production volumes of 100 units/year were also studied by DTI with analgous economic predictions. Production volumes of 10,000 units per year will reduce capital costs substantially to $\$ 13 / G$ J (See "Integrated Vehicle Analysis" DTI, 1998). Energy costs assume a natural gas price of $\$ 5 / \mathrm{GJ}(\mathrm{HHV})$ and power price of $\$ 0.07 / \mathrm{kWh}$. 
Table B-7. Technical targets for fuel cell stack components

\begin{tabular}{|c|c|}
\hline Component & Requirement \\
\hline Membranes & $\begin{array}{l}\text { Cost: } \$ 5 / \mathrm{kW} \\
\text { Stability: }<2 \mathrm{mV} \text { w/RH } 20-100 \%,<10 \% \text { swelling } \\
\mathrm{H}_{2} \text { crossover: }<1 \mathrm{~mA} / \mathrm{cm}^{2} \\
\mathrm{O}_{2} \text { crossover: }<3 \mathrm{~mA} / \mathrm{cm}^{2} \\
\text { Area specific resistance: } 0.1 \text { ohm- } \mathrm{cm}^{2}\end{array}$ \\
\hline Electrodes & $\begin{array}{l}\text { Cost: } \$ 5 / \mathrm{kW} \\
\text { CO tolerance: } 500 \mathrm{ppm} \text { steady state, } 1000 \mathrm{ppm} \text { transient with } 0.2 \mathrm{~g} \\
\text { Pt/rated kW } \\
\text { Durability: } 5000 \text { hours } \\
\text { Utilization: } 85 \% \mathrm{H}_{2}, 60 \% \mathrm{O}_{2}\end{array}$ \\
\hline $\begin{array}{l}\text { Membrane-Electrode } \\
\text { Assembly }\end{array}$ & $\begin{array}{l}\text { Performance: } \\
\text { On hydrogen } \\
400 \mathrm{~mA} / \mathrm{cm}^{2} \text { at } 0.80 \mathrm{~V} \text { (at rated power) } \\
100 \mathrm{~mA} / \mathrm{cm}^{2} \text { at } 0.85 \mathrm{~V} \text { (at quarter power) } \\
\text { On gasoline reformate } \\
500 \mathrm{~mA} / \mathrm{cm}^{2} \text { at } 0.75 \mathrm{~V} \text { (at rated power, } 30 \mathrm{psig} \text { ) } \\
125 \mathrm{~mA} / \mathrm{cm}^{2} \text { at } 0.83 \mathrm{~V} \text { (at quarter power, } 9 \mathrm{psig} \text { ) } \\
\text { Cost: } \$ 10 / \mathrm{kW}\end{array}$ \\
\hline Bipolar Plates & $\begin{array}{l}\text { Cost: } \$ 10 / \mathrm{kW} ;<1 \mathrm{~kg} / \mathrm{kW} \\
\mathrm{H}_{2} \text { permeation rate: }<2 \times 10^{-6} \mathrm{~cm}^{3} \mathrm{sec}^{-1} \mathrm{~cm}^{-2} @ 80^{\circ} \mathrm{C}, 3 \mathrm{~atm} \\
\quad\left(\text { Equivalent to }<0.1 \mathrm{~mA} / \mathrm{cm}^{2}\right) \\
\text { Corrosion limit: }<16 \mathrm{microamps} / \mathrm{cm}^{2} \\
\text { Resistivity: } 0.02 \mathrm{ohm} / \mathrm{cm}^{2}\end{array}$ \\
\hline
\end{tabular}


Table B-8. Technical targets for sensors for automotive fuel cell systems ${ }^{a}$

\begin{tabular}{|c|c|}
\hline Sensor & Requirements \\
\hline Carbon Monoxide & $\begin{array}{l}\text { (a) } 1-100 \text { ppm reformate pre-stack sensor } \\
\text { - Operational temperature: }<150^{\circ} \mathrm{C} \\
\text { - Response time: } 0.1-1 \text { sec } \\
\text { - Gas environment: high-humidity reformer/partial oxidation gas: } \mathrm{H}_{2} \\
30-75 \%, \mathrm{CO}_{2}, \mathrm{CO}, \mathrm{N}_{2}, \mathrm{H}_{2} \mathrm{O} \text { at } 1-3 \mathrm{~atm} \text { total pressure } \\
\text { - Accuracy: } 1-10 \% \text { full scale } \\
\text { (b) } 100-1000 \text { ppm } \mathrm{CO} \text { sensors } \\
\text { - Operational temperature: } 250^{\circ} \mathrm{C} \\
\text { - Response time: } 0.1-1 \mathrm{sec} \\
\text { - Gas environment: high-humidity reformer/partial oxidation gas: } \mathrm{H}_{2} \\
\quad 30-75 \%, \mathrm{CO}_{2}, \mathrm{CO}, \mathrm{N}_{2}, \mathrm{H}_{2} \mathrm{O} \text { at } 1-3 \text { atm total pressure } \\
\text { - Accuracy: } 1-10 \% \text { full scale } \\
\text { (c) } 0.1-2 \% \mathrm{CO} \text { sensor } 250-800^{\circ} \mathrm{C} \\
\text { - Operational temperature: } 250-800^{\circ} \mathrm{C} \text {. } \\
\text { - Response time: } 0.1-1 \text { sec } \\
\text { - Gas environment: high-humidity reformer/partial oxidation gas: } \mathrm{H}_{2} \\
\text { - } 30-75 \%, \mathrm{CO}_{2}, \mathrm{CO}, \mathrm{N}_{2}, \mathrm{H}_{2} \mathrm{O} \text { at } 1-3 \text { atm total pressure } \\
\text { Accuracy: } 1-10 \% \text { full scale }\end{array}$ \\
\hline $\begin{array}{l}\text { Hydrogen in fuel } \\
\text { processor output }\end{array}$ & 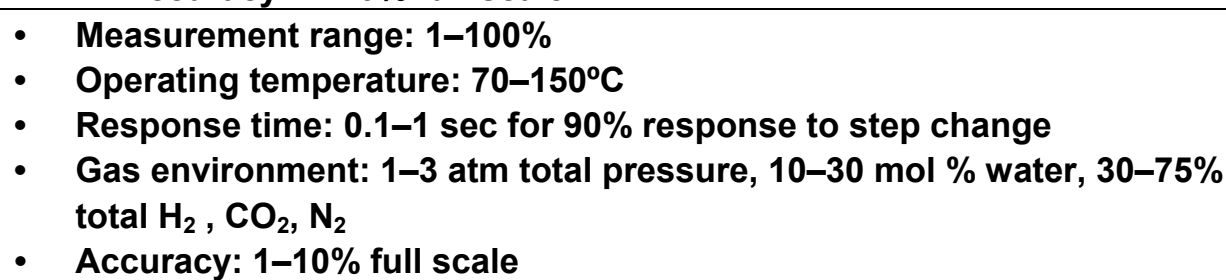 \\
\hline $\begin{array}{l}\text { Hydrogen in } \\
\text { ambient air (safety } \\
\text { sensor) }\end{array}$ & $\begin{array}{l}\text { - } \text { Measurement range: } 0.1-10 \% \\
\text { - } \quad \text { Temperature range: }-30 \text { to } 80^{\circ} \mathrm{C} \\
\text { - } \text { Response time: under } 1 \mathrm{sec} \\
\text { - } \text { Accuracy: } 5 \% \\
\text { - } \quad \text { Gas environment: ambient air, } 10-98 \% \text { RH range } \\
\text { - Lifetime: } 5 \text { years } \\
\text { - Interference resistant (e.g., hydrocarbons) }\end{array}$ \\
\hline $\begin{array}{l}\text { Sulfur compounds } \\
\left(\mathrm{H}_{2} \mathrm{~S}, \mathrm{SO}_{2} \text {, organic }\right. \\
\text { sulfur) }\end{array}$ & $\begin{array}{l}\text { - Operating temperature: up to } 400^{\circ} \mathrm{C} \\
\text { - } \quad \text { Measurement range: } 0.05-0.5 \mathrm{ppm} \\
\text { - Response time: }<1 \mathrm{~min} \text { at } 0.05 \mathrm{ppm} \\
\text { - } \text { Gas environment: } \mathrm{Hydrogen}, \mathrm{CO}, \mathrm{CO}_{2} \text {, hydrocarbons, water vapor }\end{array}$ \\
\hline $\begin{array}{l}\text { Flow rate of fuel } \\
\text { processor output }\end{array}$ & $\begin{array}{l}\text { - Flow rate range: } 30-300 \text { standard } \mathrm{L} / \mathrm{min} \\
\text { - Temperature: } 80^{\circ} \mathrm{C} \\
\text { - Gas environment: high-humidity reformer/partial oxidation gas: } \mathrm{H}_{2} \\
30-75 \%, \mathrm{CO}_{2}, \mathrm{~N}_{2}, \mathrm{H}_{2} \mathrm{O}, \mathrm{CO} \text { at } 1-3 \text { atm total pressure }\end{array}$ \\
\hline Ammonia & $\begin{array}{l}\text { - Operating temperature: } 70-150^{\circ} \mathrm{C} \\
\text { - } \text { Measurement range: } 1-10 \mathrm{ppm} \\
\text { - Selectivity: }<1 \mathrm{ppm} \text { from matrix gases } \\
\text { - } \text { Lifetime: } 5-10 \text { years } \\
\text { - } \text { Response time: seconds } \\
\text { - Gas environment: high-humidity reformer/partial oxidation gas: } \mathrm{H}_{2} \\
\quad 30-75 \%, \mathrm{CO}_{2}, \mathrm{~N}_{2}, \mathrm{H}_{2} \mathrm{O}, \mathrm{CO} \text { at } 1-3 \text { atm total pressure }\end{array}$ \\
\hline Temperature & $\begin{array}{l}\text { - Operating range: }-40 \text { to } 150^{\circ} \mathrm{C} \\
\text { - Response time: in the }-40 \text { to } 100^{\circ} \mathrm{C} \text { range }<0.5 \mathrm{sec} \text { with } 1.5 \%\end{array}$ \\
\hline
\end{tabular}


Table B-8. Technical targets for sensors for automotive fuel cell systems ${ }^{a}$

\begin{tabular}{|c|c|}
\hline Sensor & Requirements \\
\hline & $\begin{array}{l}\text { accuracy; in the } 100-150 \mathrm{C} \text { range, a response time }<1 \text { sec with } 2 \% \\
\text { accuracy } \\
\text { - Gas environment: high-humidity reformer/partial oxidation gas: } \mathrm{H}_{2} \\
30-75 \%, \mathrm{CO}_{2}, \mathrm{~N}_{2}, \mathrm{H}_{2} \mathrm{O}, \mathrm{CO} \text { at } 1-3 \text { atm total pressure } \\
\text { - Insensitive to flow velocity }\end{array}$ \\
\hline $\begin{array}{l}\text { Relative humidity for } \\
\text { cathode and anode } \\
\text { gas streams }\end{array}$ & $\begin{array}{l}\text { - } \text { Operating temperature: } 30-110^{\circ} \mathrm{C} \\
\text { - } \quad \text { Relative humidity: } 20-100 \% \\
\text { - } \quad \text { Accuracy: } 1 \% \\
\text { - Gas environment: high-humidity reformer/partial oxidation gas: } \mathrm{H}_{2} \\
30-75 \%, \mathrm{CO}_{2}, \mathrm{~N}_{2}, \mathrm{H}_{2} \mathrm{O}, \mathrm{CO} \text { at } 1-3 \mathrm{~atm} \\
\end{array}$ \\
\hline $\begin{array}{l}\text { Oxygen in fuel } \\
\text { processor and at } \\
\text { cathode exit }\end{array}$ & $\begin{array}{l}\text { (a) Oxygen sensors for fuel processor reactor control } \\
\text { - Operating temperature: } 200-800 \mathrm{C} \\
\text { - Measurement range: } 0-20 \% \mathrm{O}_{2} \\
\text { - Response time: }<0.5 \mathrm{sec} \\
\text { - Accuracy: } 2 \% \text { of full scale } \\
\text { - Gas environment: high-humidity reformer/partial oxidation gas: } \\
\text { (b) Oxygen sensors at the cathode exit } \\
\text { - Measurement range: } 0-50 \% \mathrm{O}_{2} \\
\text { - Operating temperature: } 30-110 \mathrm{C} \\
\text { - Response time: }<0.5 \mathrm{sec} \\
\text { - Accuracy: } 1 \% \text { of full scale } \\
\text { - Gas environment: } \mathrm{H}_{2}, \mathrm{CO}_{2}, \mathrm{~N}_{2}, \mathrm{H}_{2} \mathrm{O} \text { at } 1-3 \text { atm total pressure }\end{array}$ \\
\hline $\begin{array}{l}\text { Differential pressure } \\
\text { in fuel cell stack }\end{array}$ & $\begin{array}{l}\text { - Range: } 0-1 \text { psi or (0-10 or } 1-3 \text { psi, depending on the design of the } \\
\text { fuel cell system) } \\
\text { - Temperature range: } 30-100 \mathrm{C} \\
\text { - Survivability: }-40 \mathrm{C} \\
\text { - Response time: }<1 \mathrm{sec} \\
\text { - } \text { Accuracy: } 1 \% \text { of full scale } \\
\text { - Size: } 1 \text { in } 2 \text { usable in any orientation } \\
\text { - Other: Withstand and measure liquid and gas phases }\end{array}$ \\
\hline
\end{tabular}

${ }^{a}$ Sensors must conform to size, weight, and cost constraints of automotive applications. 
Table B-9. Technical targets for compressor/expander (C/E) units for automotive fuel cell systems $^{a}$

\begin{tabular}{|c|c|c|}
\hline Characteristic & Units & Target \\
\hline Input power ${ }^{b}$ at full flow & $\mathrm{kW}$ & 4.3 \\
\hline $\begin{array}{l}\text { Efficiency at full flow } \\
\text { Compressor (at } 3.2 \text { pressure ratio }{ }^{c} \\
\text { Expander }\end{array}$ & $\begin{array}{l}\% \\
\%\end{array}$ & $\begin{array}{l}75 \\
90\end{array}$ \\
\hline $\begin{array}{l}\text { Efficiency @ } 20 \% \text { of full flow } \\
\text { Compressor (at } 1.6 \text { pressure ratio) } \\
\text { Expander }\end{array}$ & $\begin{array}{l}\% \\
\%\end{array}$ & $\begin{array}{l}65 \\
80\end{array}$ \\
\hline Volume $^{d}$ & $\mathrm{~L}$ & 4 \\
\hline Weight $^{d}$ & $\mathrm{~kg}$ & 3 \\
\hline Cost $^{d, e}$ & $\$$ & 200 \\
\hline Turndown ratio & & 10 \\
\hline Noise & $\mathrm{db}$ & $<80$ \\
\hline
\end{tabular}

a Targets are being reviewed as a result of the Compressor Peer Review.

$b$ Input power to the controller to power a compressor/expander system producing $76 \mathrm{~g} / \mathrm{sec}$ (dry) maximum flow. This flow rate roughly corresponds to maximum power for a $50-\mathrm{kW}$ fuel cell system. A 25\% flow is $19 \mathrm{~g} / \mathrm{sec}$. Expander inlet conditions are assumed to be: $82 \mathrm{~g} / \mathrm{sec}, 150 \mathrm{C}$, and $2.8 \mathrm{~atm}$ (at full flow).

$c$ The pressure ratio is allowed to float as a function of load on the fuel cell system (i.e., as a function of the flow through the compressor/expander unit).

$d$ Weight, volume, and cost do not include the motor/controller or heat rejection (if required).

e Cost target based on a manufacturing volume of 100,000 units per year. 
Table B-10. Technical targets for fuel processor catalysts and reactors (for reforming Tier II gasoline containing 30 ppm Sulfur) ${ }^{a}$

\begin{tabular}{|c|c|c|c|c|c|}
\hline Characteristic & Units & $\begin{array}{c}\text { Autothermal } \\
\text { Reformer }\end{array}$ & $\begin{array}{c}\text { Sulfur } \\
\text { Removal }\end{array}$ & $\begin{array}{c}\text { Water Gas } \\
\text { Shift }\end{array}$ & $\begin{array}{l}\text { CO Preferential } \\
\text { Oxidation }\end{array}$ \\
\hline $\mathrm{GHSV}^{b}$ & per hour & 200,000 & 50,000 & 30,000 & 150,000 \\
\hline Conversion $^{c}$ & $\%$ & $>99.9$ & $>99.95$ & $>90$ & $>99.8$ \\
\hline $\begin{array}{l}\mathrm{H} 2 \text { selectivity }^{d} \text { (or } \\
\text { consumption) }\end{array}$ & $\%$ & $>80$ & $<0.1$ & $>99$ & $<0.2$ \\
\hline Volume $e^{e}$ & $\mathrm{~L} / \mathrm{kWe}$ & $<0.013$ & $<0.06$ & $<0.1$ & $<0.02$ \\
\hline Weight $^{e}$ & $\mathrm{~kg} / \mathrm{kWe}$ & $<0.015$ & $<0.06$ & $<0.1$ & $<0.03$ \\
\hline Durability $^{f}$ & hours & 5000 & 5000 & 5000 & 5000 \\
\hline Cost & $\$ / \mathrm{kWe}$ & $<5$ & $<1$ & $<1$ & $<1$ \\
\hline
\end{tabular}

a GHSV (gas hourly space velocity) = the volumetric flow rate of the product gases reduced to $25^{\circ} \mathrm{C}$ and $1 \mathrm{~atm}$, divided by the bulk volume of the catalyst.

$b$ Target values are guidelines for single reactor R\&D; system/subsystem targets take precedence.

$c$ Conversion: (moles of reactant in - moles of reactant out) $\times 100 /($ moles of reactant in).

$d$ Selectivity: At the autothermal reformer: (moles of $\mathrm{H}_{2}$ in product) $\times 100 /\left(\right.$ moles of $\mathrm{H}_{2}$ "extractable" from the reformer feed); at the shift reactor: (moles CO converted to $\mathrm{H}_{2}$ ) $\times 100 /($ total moles of CO converted).

e The volume and weight targets include only the catalysts, not the hardware needed to house the catalysts or any heat exchangers.

${ }^{f}$ Over standard driving cycles. 
Table C-1. Summary of HC Fractions

\begin{tabular}{|c|c|c|c|c|c|c|c|c|}
\hline & $\begin{array}{l}\text { Representativ } \\
\text { e from Set }\end{array}$ & $\begin{array}{c}\text { Aromatic } \\
\%\end{array}$ & $\begin{array}{l}\text { Saturate, } \\
\text { Alcohol \% }\end{array}$ & $\begin{array}{l}\text { Olefin } \\
\%\end{array}$ & $\begin{array}{l}\text { Power } \\
(\mathbf{k W})\end{array}$ & Sample\# & $\begin{array}{c}\text { Methane } \\
\%\end{array}$ & $\begin{array}{c}\text { NMHC } \\
\%\end{array}$ \\
\hline Fuel & $\begin{array}{l}\text { gasoline } \\
\text { ethanol }\end{array}$ & $\begin{array}{c}35.00 \\
0\end{array}$ & $\begin{array}{c}64.32 \\
100\end{array}$ & $\begin{array}{c}0.49 \\
0\end{array}$ & $\begin{array}{l}\text { gasoline } \\
\text { ethanol }\end{array}$ & - & $\begin{array}{l}0 \\
0\end{array}$ & $\begin{array}{l}100 \% \\
100 \%\end{array}$ \\
\hline Startup & Nuvera B 2000 & 74.86 & 25.14 & 0.00 & 20.00 & NP1T14.41.00 & $0 \%$ & $100 \%$ \\
\hline PrOx & $\begin{array}{l}\text { Nuvera B } 2000 \\
\text { MTI } 2002 \\
\text { Nuvera EtOH } \\
2003\end{array}$ & $\begin{array}{c}40.84 \\
0.06 \% \\
5 \%\end{array}$ & $\begin{array}{c}59.16 \\
96.81 \% \\
41 \%\end{array}$ & $\begin{array}{c}0.00 \\
3.12 \% \\
54 \%\end{array}$ & $\begin{array}{l}15.00 \\
12.1 \\
35 \%\end{array}$ & $\begin{array}{l}\text { NP2P17.25.40 } \\
\text { MBP-3100 } \\
\text { N-D-P-17 }\end{array}$ & $\begin{array}{l}100 \% \\
88 \% \\
100 \%\end{array}$ & $\begin{array}{l}0 \% \\
12 \% \\
0 \%\end{array}$ \\
\hline AGB & $\begin{array}{l}\text { Nuvera B } 2000 \\
\text { MTI } 2002 \\
\text { Nuvera EtOH } \\
2003\end{array}$ & $\begin{array}{c}36.25 \\
0.00 \% \\
0 \%\end{array}$ & $\begin{array}{c}63.75 \\
74.51 \% \\
86 \%\end{array}$ & $\begin{array}{c}0.00 \\
25.49 \% \\
14 \%\end{array}$ & $\begin{array}{l}35.00 \\
11.4 \\
60 \%\end{array}$ & $\begin{array}{c}\text { NP2T17.20.30 } \\
\text { average } \\
\text { N-C-T-9 }\end{array}$ & $\begin{array}{l}95 \% \\
50 \% \\
93 \%\end{array}$ & $\begin{array}{l}5 \% \\
50 \% \\
7 \%\end{array}$ \\
\hline
\end{tabular}

\section{C.1 Nuvera Gasoline B ATR}

Table C-2. Summary of Hydrocarbon Speciation Results, Nuvera B ATR

\begin{tabular}{|c|c|c|c|c|c|}
\hline Sample Name & $\begin{array}{l}\text { Sample } \\
\text { Location }\end{array}$ & $\begin{array}{l}\text { Nominal } \\
\text { FPA Power } \\
\text { (kW) }\end{array}$ & $\begin{array}{c}\text { Mass \% of } \\
\text { HC as } \\
\text { Aromatic }\end{array}$ & $\begin{array}{c}\text { Mass \% of } \\
\text { HC as } \\
\text { Saturate }\end{array}$ & $\begin{array}{c}\text { Mass \% of } \\
\text { HC as } \\
\text { Olefin }\end{array}$ \\
\hline NP2T17.28.10 & TGC & & 35 & 64.32 & 0.486 \\
\hline NP2P17.25.40(2) & Prox & 15 & 41.18 & 58.82 & 0.00 \\
\hline NP2P17.25.40 & Prox & 15 & 40.84 & 59.16 & 0.00 \\
\hline NP2T16.42.13 & TGC & 22.5 & 63.05 & 36.95 & 0.00 \\
\hline NP1T14.41.00 & TGC & 20 & 74.86 & 25.14 & 0.00 \\
\hline NP2T17.20.30 & TGC & 35 & 36.25 & 63.75 & 0.00 \\
\hline NP1T15.09.00 & TGC & 45 & 38.29 & 57.86 & 3.85 \\
\hline Fuel & Fuel & Base- & 35 & 64.32 & 0.486 \\
\hline
\end{tabular}


Table C-3. Hydrocarbon Speciation from MTI ATR

\begin{tabular}{|c|c|c|c|c|c|c|c|c|c|c|c|c|c|}
\hline Sample & Benzene & Butane & $\begin{array}{c}1- \\
\text { Butene }\end{array}$ & $\begin{array}{l}\text { trans-2- } \\
\text { butene }\end{array}$ & $\begin{array}{c}\text { 2,3- } \\
\text { Dimethyl } \\
\text { pentane }\end{array}$ & $\begin{array}{c}\text { 2,4- } \\
\text { Dimethyl } \\
\text { pentane }\end{array}$ & Isopentane & Isobutane & $\begin{array}{l}\text { cis-2- } \\
\text { Pentene }\end{array}$ & $\begin{array}{l}\text { trans-2- } \\
\text { Pentene }\end{array}$ & Toluene & Isooctane & $\begin{array}{c}2,3,4- \\
\text { Trimethyl } \\
\text { pentane }\end{array}$ \\
\hline MAT & PPM & PPM & PPM & PPM & PPM & PPM & PPM & PPM & PPM & PPM & PPM & PPM & PPM \\
\hline 1300 & 0.0 & 0 & 0.000 & 0 & 0 & 0 & 0.02 & 0 & 0 & 0 & 0 & 0.052 & 0 \\
\hline 1900 & 0 & 0 & 0.026 & 0 & 0 & 0 & 0 & 0 & 0 & 0 & 0 & 0 & 0 \\
\hline 2500 & 0 & 0 & 0.000 & 0 & 0 & 0 & 0 & 0 & 0 & 0 & 0 & 0 & 0 \\
\hline 3100 & 0 & 0 & 0.036 & 0 & 0 & 0 & 0 & 0 & 0 & 0 & 0.0067 & 0 & 0 \\
\hline 3700 & 0 & 0 & 0.000 & 0 & 0 & 0 & 0 & 0 & 0 & 0 & 0 & 0 & 0 \\
\hline 5200 & 0 & 0 & 0.000 & 0 & 0 & 0 & 0 & 0 & 0 & 0 & 0 & 0 & 0 \\
\hline MBP & PPM & PPM & PPM & PPM & PPM & PPM & PPM & PPM & PPM & PPM & PPM & PPM & PPM \\
\hline 1300 & 5.3 & 0 & 56 & 0 & 11 & 0 & 87 & 86 & 0 & 0 & 0 & 230 & 0 \\
\hline 1900 & 6.8 & 0 & 72 & 0 & 12 & 0 & 98 & 74 & 0 & 0 & 0 & 260 & 0 \\
\hline 2500 & 4.8 & 12 & 100 & 4.6 & 9.7 & 0 & 91 & 110 & 0 & 0 & 1.2 & 210 & 5 \\
\hline 2500 Dup & 4.5 & 10 & 92 & 4.5 & 9 & 0 & 82 & 100 & 0 & 0 & 1 & 190 & 4.4 \\
\hline 3100 & 5.6 & 9.7 & 92 & 0 & 9.9 & 0 & 87 & 99 & 0 & 0 & 0 & 210 & 5.6 \\
\hline 3700 & 5.8 & 9.8 & 87 & 0 & 9.9 & 4.8 & 86 & 100 & 0 & 0 & 1.2 & 210 & 5.5 \\
\hline 5200 & 5.8 & 9.3 & 65 & 0 & 12 & 0 & 100 & 97 & 0 & 0 & 0 & 250 & 7.1 \\
\hline MCP & PPM & PPM & PPM & PPM & PPM & PPM & PPM & PPM & PPM & PPM & PPM & PPM & PPM \\
\hline 23500 & 4.2 & 9.3 & 130 & 6.3 & 8 & 0 & 79 & 95 & 0 & 0 & 1.4 & 180 & 4.5 \\
\hline MCT & PPM & PPM & PPM & PPM & PPM & PPM & PPM & PPM & PPM & PPM & PPM & PPM & PPM \\
\hline 1300 & 0 & 0 & 0 & 0 & 0 & 0 & 0 & 0 & 0 & 0 & 0 & 0 & 0 \\
\hline 12400 & 0 & 0 & 0 & 0 & 0 & 0 & 0.005 & 0 & 0 & 0 & 0.0056 & 0.015 & 0 \\
\hline 22900 & 0 & 0 & 0.0055 & 0 & 0 & 0 & 0 & 0 & 0 & 0 & 0 & 0.0063 & 0 \\
\hline 22900 Dup & 0 & 0 & 0.0068 & 0 & 0 & 0 & 0 & 0 & 0 & 0 & 0 & 0.0071 & 0 \\
\hline 24100 & 0 & 0 & 0.0033 & 0 & 0 & 0 & 0 & 0 & 0 & 0 & 0 & & 0 \\
\hline MDP & PPM & PPM & PPM & PPM & PPM & PPM & PPM & PPM & PPM & PPM & PPM & PPM & PPM \\
\hline 1300 & 1.8 & 3.8 & 48 & 2 & 0.83 & 0 & 18 & 36 & 1.1 & 0.75 & 0.49 & 17 & 0 \\
\hline 12400 & 2.9 & 6.2 & 64 & 3.2 & 4.2 & 0 & 46 & 66 & 0 & 0 & 0.78 & 94 & 0 \\
\hline & Aromatic & Saturated & Olefin & Olefin & Saturated & Saturated & Saturated & Saturated & Olefin & Olefin & Aromatic & Saturated & Saturated \\
\hline
\end{tabular}


Table C-3. Hydrocarbon Speciation from MTI ATR (continued)

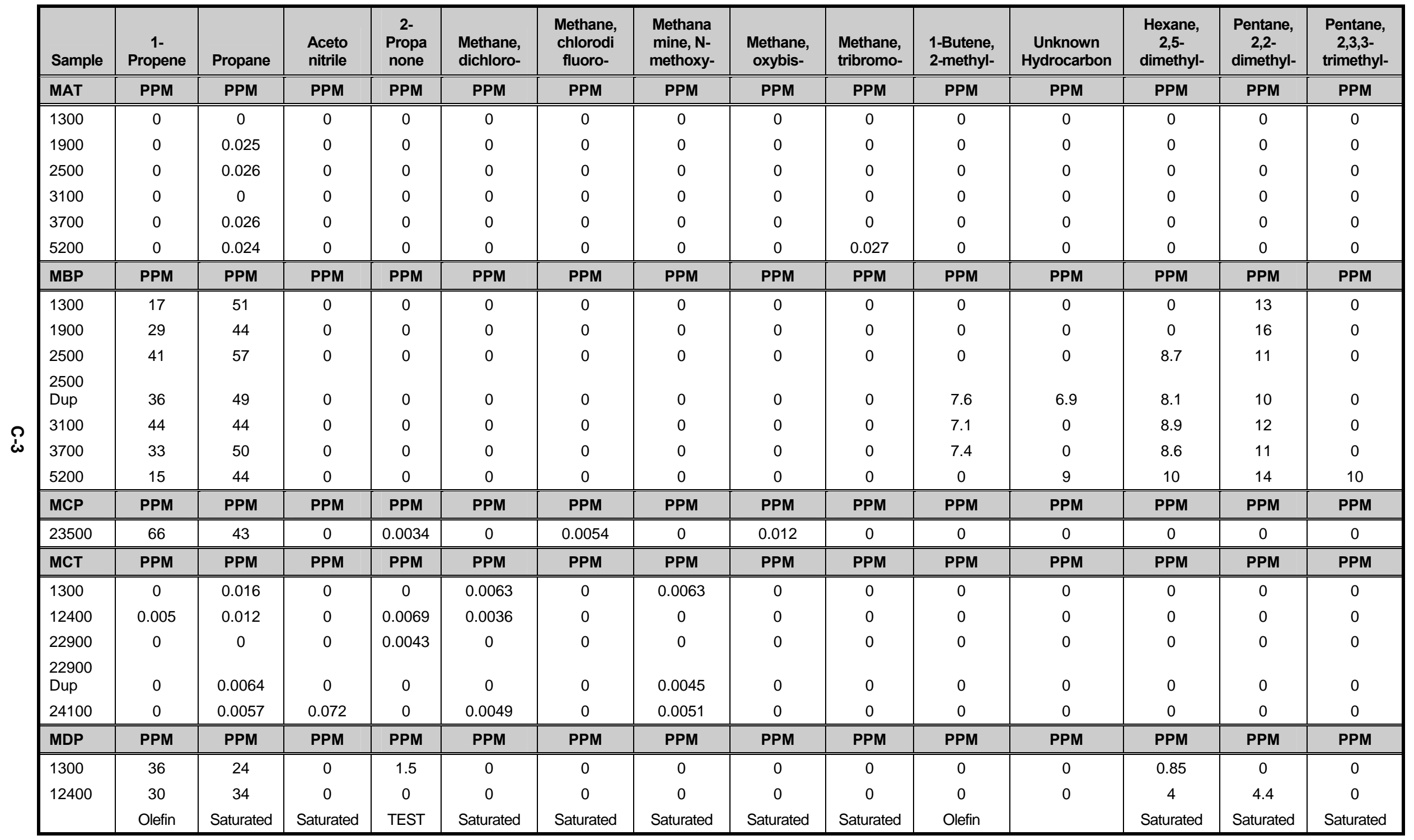


Table C-3. Hydrocarbon Speciation from MTI ATR (concluded)

\begin{tabular}{|c|c|c|c|c|c|c|c|c|c|c|c|c|c|c|}
\hline$\frac{\text { Sample }}{\text { MAT }}$ & $\begin{array}{c}\text { Ethane } \\
\text { ppm }\end{array}$ & $\begin{array}{c}\text { Ethene } \\
\text { ppm }\end{array}$ & $\begin{array}{c}\begin{array}{c}\text { Acetyl } \\
\text { ene }\end{array} \\
\text { ppm }\end{array}$ & $\begin{array}{c}\text { Propane } \\
\text { ppm }\end{array}$ & $\begin{array}{c}\begin{array}{c}\text { Propyl } \\
\text { ene }\end{array} \\
\text { ppm }\end{array}$ & $\begin{array}{c}\text { Methane } \\
\text { PPM }\end{array}$ & & TOTAL & \%Aromatic & \%Saturate & $\%$ Olefin & Power & $\begin{array}{l}\text { TGB, } \\
\text { PrOx, } \\
\text { Startup }\end{array}$ & Methane \% \\
\hline 1300 & 0.00 & 0.00 & 0.00 & 0.00 & 0.00 & & MAT-1300 & 1300.072 & $0.00 \%$ & $0.01 \%$ & $0.00 \%$ & 11.6 & TGB & $0.0 \%$ \\
\hline 1900 & 0 & 0 & 0 & 0 & 0 & & MAT-1900 & 1900.051 & $0.00 \%$ & $0.00 \%$ & $0.00 \%$ & 11.5 & TGB & $0.0 \%$ \\
\hline 2500 & 0 & 0 & 0 & 0 & 0 & & MAT-2500 & 2500.026 & $0.00 \%$ & $0.00 \%$ & $0.00 \%$ & 11.4 & TGB & $0.0 \%$ \\
\hline 3100 & 0 & 0 & 0 & 0 & 0 & & MAT-3100 & 3100.043 & $0.00 \%$ & $0.00 \%$ & $0.00 \%$ & 9.8 & TGB & $0.0 \%$ \\
\hline 3700 & 0 & 0 & 0 & 0 & 0 & & MAT-3700 & 3700.026 & $0.00 \%$ & $0.00 \%$ & $0.00 \%$ & 8.6 & TGB & $0.0 \%$ \\
\hline 5200 & & & & & & & MAT-5200 & 5200.051 & $0.00 \%$ & $0.00 \%$ & $0.00 \%$ & 11.5 & TGB & $0.0 \%$ \\
\hline MBP & & & & & & & & & \%Aromatic & \%Saturate & \%Olefin & Power & & \\
\hline 1300 & 130 & 6.8 & 0 & 120 & 38 & 4900 & MBP-1300 & 7051.100 & $0.08 \%$ & $79.82 \%$ & $1.67 \%$ & 6.3 & PrOx & $69.5 \%$ \\
\hline 1900 & 120 & 18 & 0 & 100 & 62 & 8200 & MBP-1900 & 11011.800 & $0.06 \%$ & $81.04 \%$ & $1.64 \%$ & 9 & PrOx & $74.5 \%$ \\
\hline 2500 & 140 & 15 & 0 & 100 & 52 & 6600 & MBP-2500 & 10073.000 & $0.06 \%$ & $73.01 \%$ & $2.11 \%$ & 8.8 & PrOx & $65.5 \%$ \\
\hline $\begin{array}{l}2500 \\
\text { Dup }\end{array}$ & & & & & & & & & & & & & PrOx & \\
\hline 3100 & 160 & 39 & 0 & 130 & 88 & 7600 & MBP-3100 & 11751.800 & $0.05 \%$ & $71.28 \%$ & $2.30 \%$ & 12.1 & PrOx & $64.7 \%$ \\
\hline 3700 & 170 & 19 & 0 & 140 & 66 & 8100 & MBP-3700 & 12825.000 & $0.05 \%$ & $69.44 \%$ & $1.66 \%$ & 11.9 & PrOx & $63.2 \%$ \\
\hline 5200 & 140 & 5.9 & 0 & 110 & 26 & 6600 & MBP-5200 & 12721.100 & $0.05 \%$ & $58.20 \%$ & $0.88 \%$ & 8 & PrOx & $51.9 \%$ \\
\hline \multicolumn{15}{|l|}{ MCP } \\
\hline 23500 & 170 & 53 & 0 & 120 & 110 & & MCР-23500 & 24579.721 & $0.02 \%$ & $2.88 \%$ & $1.49 \%$ & 11.8 & PrOx & $0.0 \%$ \\
\hline \multicolumn{15}{|l|}{ MCT } \\
\hline 1300 & & & & & & & MCT-1300 & 1300.029 & $0.00 \%$ & $0.00 \%$ & $0.00 \%$ & 11.9 & TGB & $0.0 \%$ \\
\hline 12400 & 0 & 0 & 0 & 0 & 0 & 1.60 & MCT-12400 & 12401.653 & $0.00 \%$ & $0.01 \%$ & $0.00 \%$ & 12 & TGB & $0.0 \%$ \\
\hline 22900 & 0 & 0 & 0 & 0 & 0 & & МСТ-22900 & 22900.016 & $0.00 \%$ & $0.00 \%$ & $0.00 \%$ & 12.1 & TGB & $0.0 \%$ \\
\hline $\begin{array}{l}22900 \\
\text { Dup }\end{array}$ & & & & & & & & & & & & & & \\
\hline 24100 & 0 & 0 & 0 & 0 & 0 & & МСТ-24100 & 24100.091 & $0.00 \%$ & $0.00 \%$ & $0.00 \%$ & 11.5 & TGB & $0.0 \%$ \\
\hline \multicolumn{15}{|l|}{ MDP } \\
\hline 1300 & & & & & & & MDP-1300 & 1492.120 & $0.15 \%$ & $6.73 \%$ & $5.89 \%$ & & & $0.0 \%$ \\
\hline 12400 & 160 & 21 & 0 & 98 & 61 & 7500 & MDP-12400 & 20599.680 & $0.02 \%$ & $38.92 \%$ & $0.87 \%$ & 11.8 & PrOx & $36.4 \%$ \\
\hline & Saturated & Olefin & Olefin & Saturated & Olefin & Saturated & & & & & & & & \\
\hline
\end{tabular}




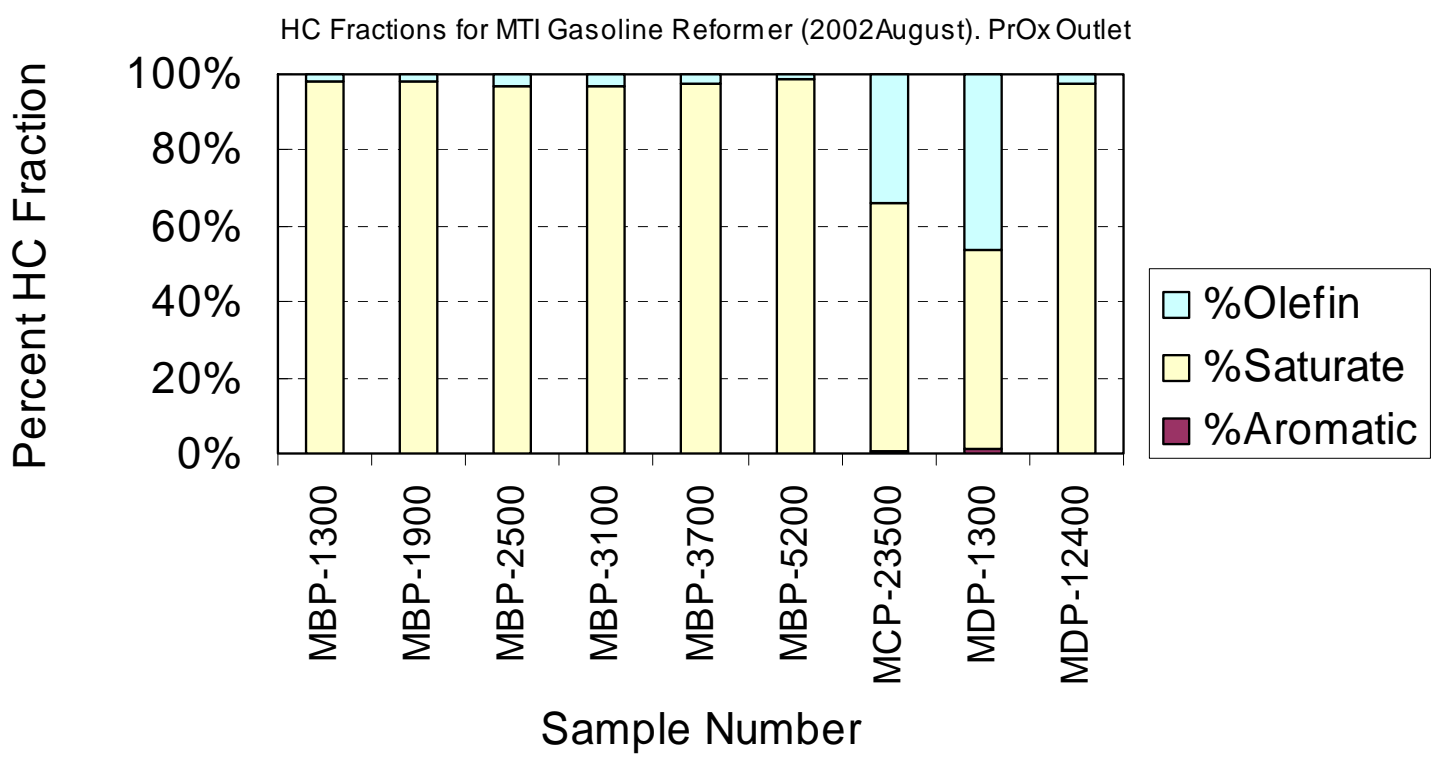

Figure C-1. HC Fractions for MTI ATR, PrOx Outlet

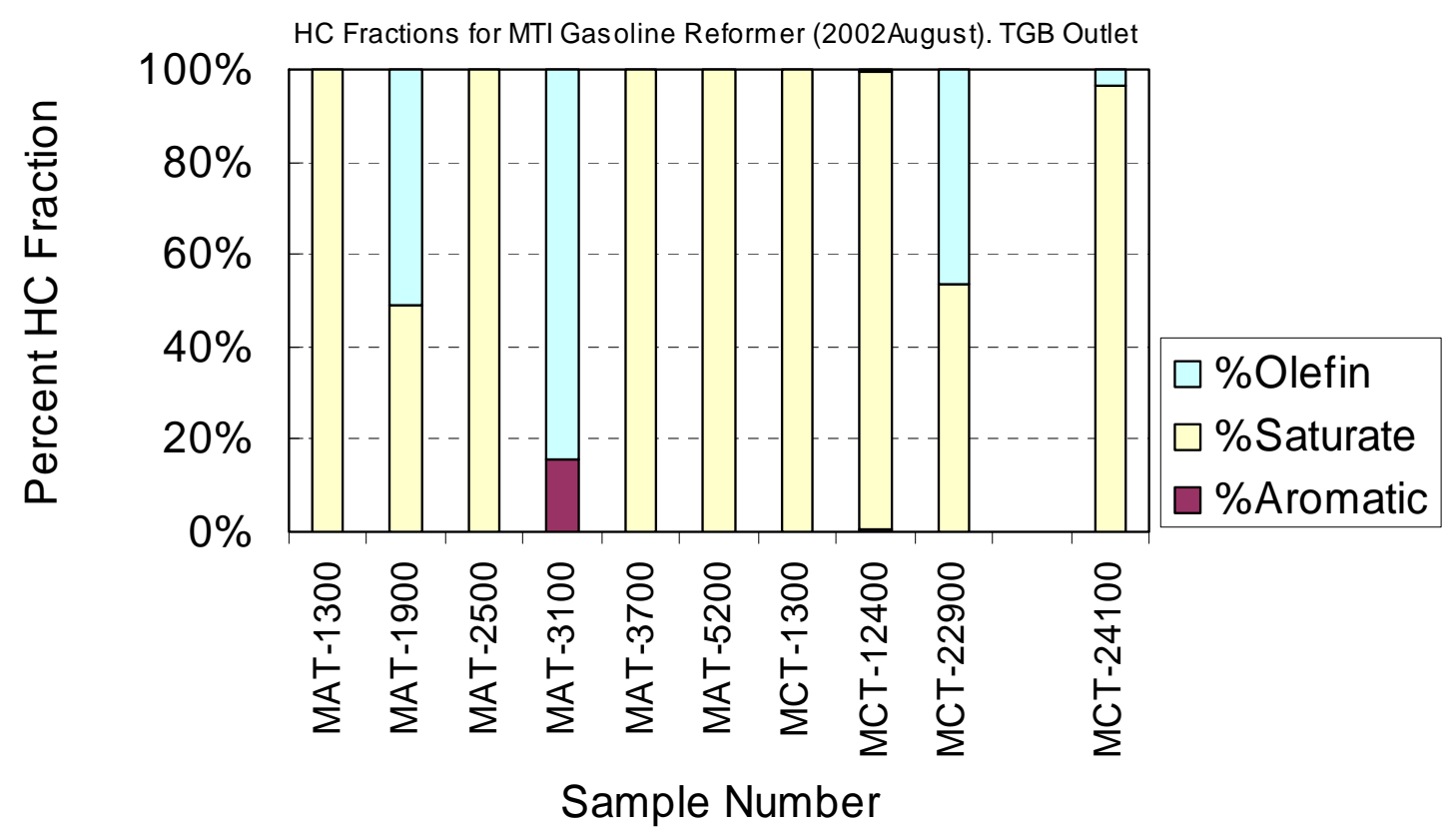

Figure C-2. HC Fractions for MTI ATR, AGB Outlet 
Table C-4. Hydrocarbon Speciation for Nuvera Ethanol ATR/PEMFC

\begin{tabular}{|c|c|c|c|c|c|c|c|c|c|c|c|c|c|c|}
\hline Sample & 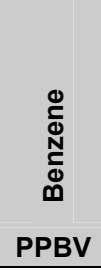 & 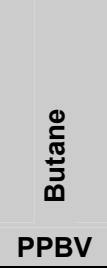 & 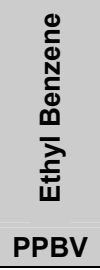 & 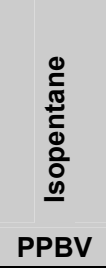 & $\begin{array}{c}\stackrel{0}{\frac{5}{\pi}} \\
\stackrel{\pi}{5} \\
\stackrel{0}{0} \\
\underline{0} \\
\text { PPBV }\end{array}$ & $\begin{array}{l}\text { ळ } \\
\text { के } \\
\text { PPBV }\end{array}$ & $\begin{array}{c}\stackrel{0}{\frac{0}{0}} \\
\stackrel{0}{\circ} \\
\text { PPBV }\end{array}$ & 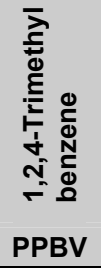 & 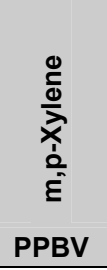 & 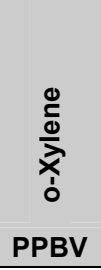 & 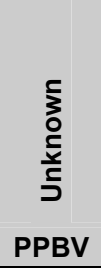 & $\begin{array}{c}\frac{5}{3} \\
\text { o } \\
\frac{5}{5} \\
\text { د } \\
\text { PPBV }\end{array}$ & 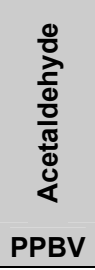 & $\begin{array}{c}\overline{0} \\
\stackrel{0}{\frac{1}{\pi}} \\
\text { 壱 } \\
\text { PPBV }\end{array}$ \\
\hline N-A-T-3 & 5 & & & & & & 9 & 9 & 9 & 5 & 3600 & 58 & & 20000 \\
\hline N-A-T-4 & & & & & & & 12 & & & & 720 & & & 23000 \\
\hline N-A-T-11 & & & & & & & 12 & & & & 780 & & & 24000 \\
\hline N-A-T-5 & & & & & & & 11 & & & & 3900 & & & 24000 \\
\hline N-A-T-6 & & & & & & & 11 & & & & 35 & 4200 & & 32000 \\
\hline N-A-T-7 & & & & & & & 12 & & & & 4500 & & & 28000 \\
\hline N-A-T-8 & 8 & & & & & & 12 & & & & 4200 & & & 34000 \\
\hline N-A-T-9 & 55 & & & & & & 13 & & & & 2200 & & & 32000 \\
\hline N-A-T-10 & 44 & & & & & & 14 & & & & 1800 & & & 34000 \\
\hline N-D-P-15 & 22 & 25 & & & & & 16 & & & & 57 & 38 & & 270 \\
\hline N-D-P-16 & 10 & & & & & & 8 & & & & 45 & 58 & & 41 \\
\hline N-D-P-6 & 9 & & & & & & 7 & & & & 48 & 62 & & 230 \\
\hline N-D-P-9 & 13 & & & & & & 15 & & & & 32 & & & \\
\hline N-D-P-17 & 11 & & & & & & 13 & & & & 72 & & & \\
\hline N-D-P-18 & 12 & 21 & & 40 & 36 & & 37 & & & & 49 & & & \\
\hline N-D-P-19 & 15 & & & & & & 13 & & & & & & & \\
\hline N-D-P-20 & 16 & & & & & & 14 & & & & 41 & & & \\
\hline N-D-P-21 & 15 & 24 & & 54 & 42 & & 49 & & & & 30 & & & 170 \\
\hline N-D-P-22 & 20 & & 5 & & & & 15 & & & & 23 & & & \\
\hline N-D-P-23 & 38 & 19 & 10 & & & & 26 & & & & & & & \\
\hline N-D-P-13 & 43 & 22 & 10 & 28 & 28 & & 42 & & & & 53 & & & \\
\hline $\mathrm{N}-\mathrm{C}-\mathrm{T}-2$ & 5 & & & & & & & & & & 75 & 81 & 420 & 6300 \\
\hline N-C-T-14 & & & & & & & & & & & 22 & 15 & & 310 \\
\hline N-C-T-6 & & & & & & & 8 & & & & & & 2100 & 2600 \\
\hline N-C-T-17 & & & & & & 70 & 46 & & & & & & 3200 & 23000 \\
\hline N-C-T-9 & & & & & & & 11 & & & & 300 & & 2600 & 34000 \\
\hline N-C-T-16 & 6 & & & & & & & & & & 29 & & 170 & 4800 \\
\hline
\end{tabular}


Table C-4. Hydrocarbon Speciation for Nuvera Ethanol ATR/PEMFC (continued)

\begin{tabular}{|c|c|c|c|c|c|c|c|c|c|c|c|c|c|c|c|}
\hline Sample & 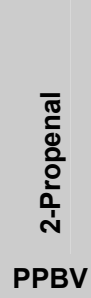 & 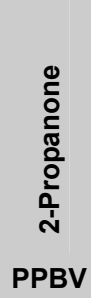 & 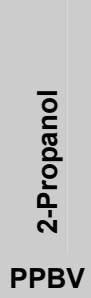 & 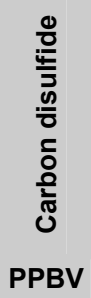 & 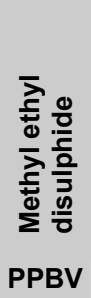 & 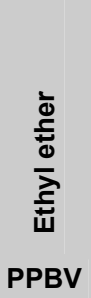 & 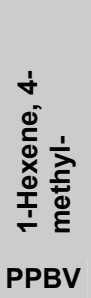 & 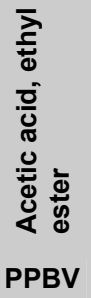 & 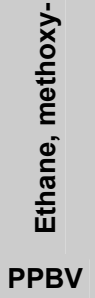 & 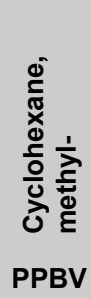 & 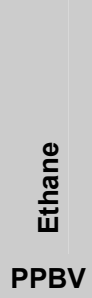 & 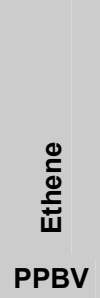 & 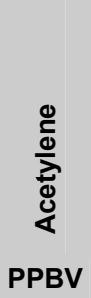 & 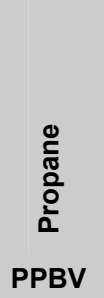 & 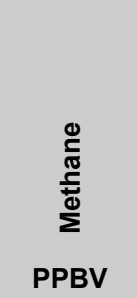 \\
\hline N-A-T-3 & & 330 & & & & 120 & 29 & 280 & 38 & & & & & & 3000000 \\
\hline N-A-T-4 & & 210 & & & & & & & & & 2600 & 1200 & & & 2900000 \\
\hline N-A-T-11 & & 220 & & & & & & & & & 3000 & 1300 & & & 3100000 \\
\hline N-A-T-5 & & 160 & & & & & & & & & 630 & 2100 & & & 2800000 \\
\hline N-A-T-6 & & & & & & & & & & & & 2900 & & & 3100000 \\
\hline N-A-T-7 & & 260 & & & & & & & & & 2900 & 7400 & & & 2000000 \\
\hline N-A-T-8 & & 210 & & & & & & & & & 3400 & 5200 & & & 3300000 \\
\hline N-A-T-9 & & 320 & & & & & & & & & 2200 & 5100 & & & 1200000 \\
\hline N-A-T-10 & & 310 & & & & & & & & & 6800 & 10000 & & & 1200000 \\
\hline N-D-P-15 & & 140 & 76 & & & & & & & 19 & & & & & 25000000 \\
\hline N-D-P-16 & & 140 & & & & & & & & & & & & & 22000000 \\
\hline N-D-P-6 & & 140 & & & & & & & & & & & & & 28000000 \\
\hline N-D-P-9 & & 170 & & & & & & & & & & & & 160 & 29000000 \\
\hline N-D-P-17 & & 240 & & & & & & & & & & & & 180 & 30000000 \\
\hline N-D-P-18 & & 220 & & & & & & & & & & & & 170 & 32000000 \\
\hline N-D-P-19 & & 270 & 63 & & & & & & & & & & & 240 & 35000000 \\
\hline N-D-P-20 & & 220 & & & & & & & & & & & & 260 & 34000000 \\
\hline N-D-P-21 & & 140 & & & & & & & & & & & & 220 & 27000000 \\
\hline N-D-P-22 & & 330 & 70 & & & & & & & & & 2600 & 3000 & 63000 & 35000000 \\
\hline N-D-P-23 & & 470 & 59 & & & & & & & & & & & 510 & 38000000 \\
\hline N-D-P-13 & & 450 & & 110 & 27 & & & & & & & & & 480 & 35000000 \\
\hline N-C-T-2 & & & & & & & & & & & & & & & 430000 \\
\hline $\begin{array}{l}\text { N-C-T-14 } \\
\text { N-C.T-6 }\end{array}$ & 78 & & & & & & & & & & 840 & 3600 & & & 260000 \\
\hline $\begin{array}{l}\text { N-C-1-6 } \\
\text { N-C-T-17 }\end{array}$ & & & & & & & & & & & 1900 & 10000 & & & $\begin{array}{l}680000 \\
170000\end{array}$ \\
\hline N-C-T-9 & & & & & & & & & & & 1900 & 6400 & & & 560000 \\
\hline N-C-T-16 & & & & & & & & & & & 940 & 1100 & & & 56000 \\
\hline
\end{tabular}


Table C-4. Hydrocarbon Speciation for Nuvera Ethanol ATR/PEMFC (Concluded)

\begin{tabular}{|c|c|c|c|c|c|c|c|c|c|c|}
\hline \multirow[b]{2}{*}{ Sample } & \multirow{2}{*}{$\begin{array}{c}\text { NMHC } \\
\text { Total }\end{array}$} & \multicolumn{3}{|c|}{ HC Fractions } & \multirow[b]{2}{*}{ Total HC } & \multicolumn{3}{|c|}{ NMHC HC Fractions } & \multirow[b]{2}{*}{ Methane \% } & \multirow[b]{2}{*}{ Location } \\
\hline & & Aromatic & Saturated & Olefin & & Aromatic & Saturated & Olefin & & \\
\hline N-A-T-3 & 20504 & $0.2 \%$ & $99.1 \%$ & $0.7 \%$ & 3020504 & $0 \%$ & $100 \%$ & $0 \%$ & $99 \%$ & TGB \\
\hline N-A-T-4 & 26812 & $0 \%$ & $95 \%$ & $4 \%$ & 2926812 & $0 \%$ & $100 \%$ & $0 \%$ & $99 \%$ & TGB \\
\hline N-A-T-11 & 28312 & $0 \%$ & $95 \%$ & $5 \%$ & 3128312 & $0 \%$ & $100 \%$ & $0 \%$ & $99 \%$ & TGB \\
\hline N-A-T-5 & 26741 & $0 \%$ & $92 \%$ & $8 \%$ & 2826741 & $0 \%$ & $100 \%$ & $0 \%$ & $99 \%$ & TGB \\
\hline N-A-T-6 & 34911 & $0 \%$ & $92 \%$ & $8 \%$ & 3134911 & $0 \%$ & $100 \%$ & $0 \%$ & $99 \%$ & TGB \\
\hline N-A-T-7 & 38312 & $0 \%$ & $81 \%$ & $19 \%$ & 2038312 & $0 \%$ & $100 \%$ & $0 \%$ & $98 \%$ & TGB \\
\hline N-A-T-8 & 42620 & $0 \%$ & $88 \%$ & $12 \%$ & 3342620 & $0 \%$ & $100 \%$ & $0 \%$ & $99 \%$ & TGB \\
\hline N-A-T-9 & 39368 & $0 \%$ & $87 \%$ & $13 \%$ & 1239368 & $0 \%$ & $100 \%$ & $0 \%$ & $97 \%$ & TGB \\
\hline N-A-T-10 & 50858 & $0 \%$ & $80 \%$ & $20 \%$ & 1250858 & $0 \%$ & $99 \%$ & $1 \%$ & $96 \%$ & TGB \\
\hline N-D-P-15 & 428 & $9 \%$ & $91 \%$ & $0 \%$ & 25000428 & $0 \%$ & $100 \%$ & $0 \%$ & $100 \%$ & PrOx \\
\hline N-D-P-16 & 59 & $31 \%$ & $69 \%$ & $0 \%$ & 22000059 & $0 \%$ & $100 \%$ & $0 \%$ & $100 \%$ & PrOx \\
\hline N-D-P-6 & 246 & $7 \%$ & $93 \%$ & $0 \%$ & 28000246 & $0 \%$ & $100 \%$ & $0 \%$ & $100 \%$ & PrOx \\
\hline N-D-P-9 & 188 & $15 \%$ & $85 \%$ & $0 \%$ & 29000188 & $0 \%$ & $100 \%$ & $0 \%$ & $100 \%$ & PrOx \\
\hline N-D-P-17 & 204 & $12 \%$ & $88 \%$ & $0 \%$ & 30000204 & $0 \%$ & $100 \%$ & $0 \%$ & $100 \%$ & PrOx \\
\hline N-D-P-18 & 316 & $16 \%$ & $84 \%$ & $0 \%$ & 32000316 & $0 \%$ & $100 \%$ & $0 \%$ & $100 \%$ & PrOx \\
\hline N-D-P-19 & 331 & $8 \%$ & $92 \%$ & $0 \%$ & 35000331 & $0 \%$ & $100 \%$ & $0 \%$ & $100 \%$ & PrOx \\
\hline N-D-P-20 & 290 & $10 \%$ & $90 \%$ & $0 \%$ & 34000290 & $0 \%$ & $100 \%$ & $0 \%$ & $100 \%$ & PrOx \\
\hline N-D-P-21 & 574 & $11 \%$ & $89 \%$ & $0 \%$ & 27000574 & $0 \%$ & $100 \%$ & $0 \%$ & $100 \%$ & PrOx \\
\hline N-D-P-22 & 68710 & $0 \%$ & $92 \%$ & $8 \%$ & 35068710 & $0 \%$ & $100 \%$ & $0 \%$ & $100 \%$ & PrOx \\
\hline N-D-P-23 & 662 & $11 \%$ & $89 \%$ & $0 \%$ & 38000662 & $0 \%$ & $100 \%$ & $0 \%$ & $100 \%$ & PrOx \\
\hline N-D-P-13 & 790 & $12 \%$ & $85 \%$ & $3 \%$ & 35000790 & $0 \%$ & $100 \%$ & $0 \%$ & $100 \%$ & PrOx \\
\hline N-C-T-2 & 6725 & $0 \%$ & $100 \%$ & $0 \%$ & 436725 & $0 \%$ & $100 \%$ & $0 \%$ & $98 \%$ & TGB \\
\hline N-C-T-14 & 310 & $0 \%$ & $100 \%$ & $0 \%$ & 260310 & $0 \%$ & $100 \%$ & $0 \%$ & $100 \%$ & TGB \\
\hline N-C-T-6 & 9226 & $0 \%$ & $61 \%$ & $39 \%$ & 689226 & $0 \%$ & $99 \%$ & $1 \%$ & $99 \%$ & TGB \\
\hline N-C-T-17 & 38216 & $0 \%$ & $74 \%$ & $26 \%$ & 208216 & $0 \%$ & $95 \%$ & $5 \%$ & $82 \%$ & TGB \\
\hline N-C-T-9 & 44911 & $0 \%$ & $86 \%$ & $14 \%$ & 604911 & $0 \%$ & $99 \%$ & $1 \%$ & $93 \%$ & TGB \\
\hline N-C-T-16 & 7016 & $0 \%$ & $84 \%$ & $16 \%$ & 63016 & $0 \%$ & $98 \%$ & $2 \%$ & $89 \%$ & TGB \\
\hline
\end{tabular}




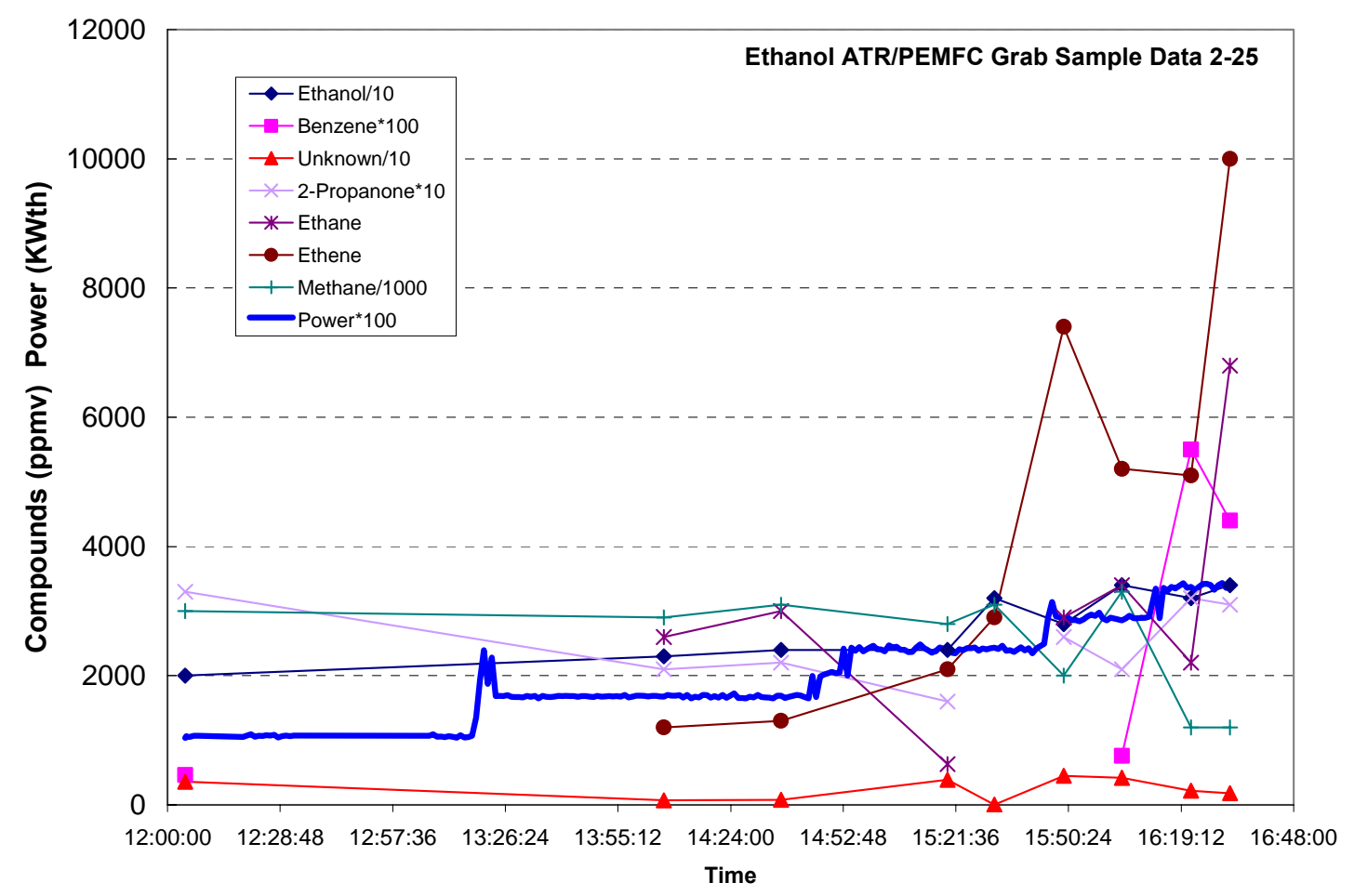

Figure C-3. Nuvera Ethanol ATR/PEMFC Speciation Summary

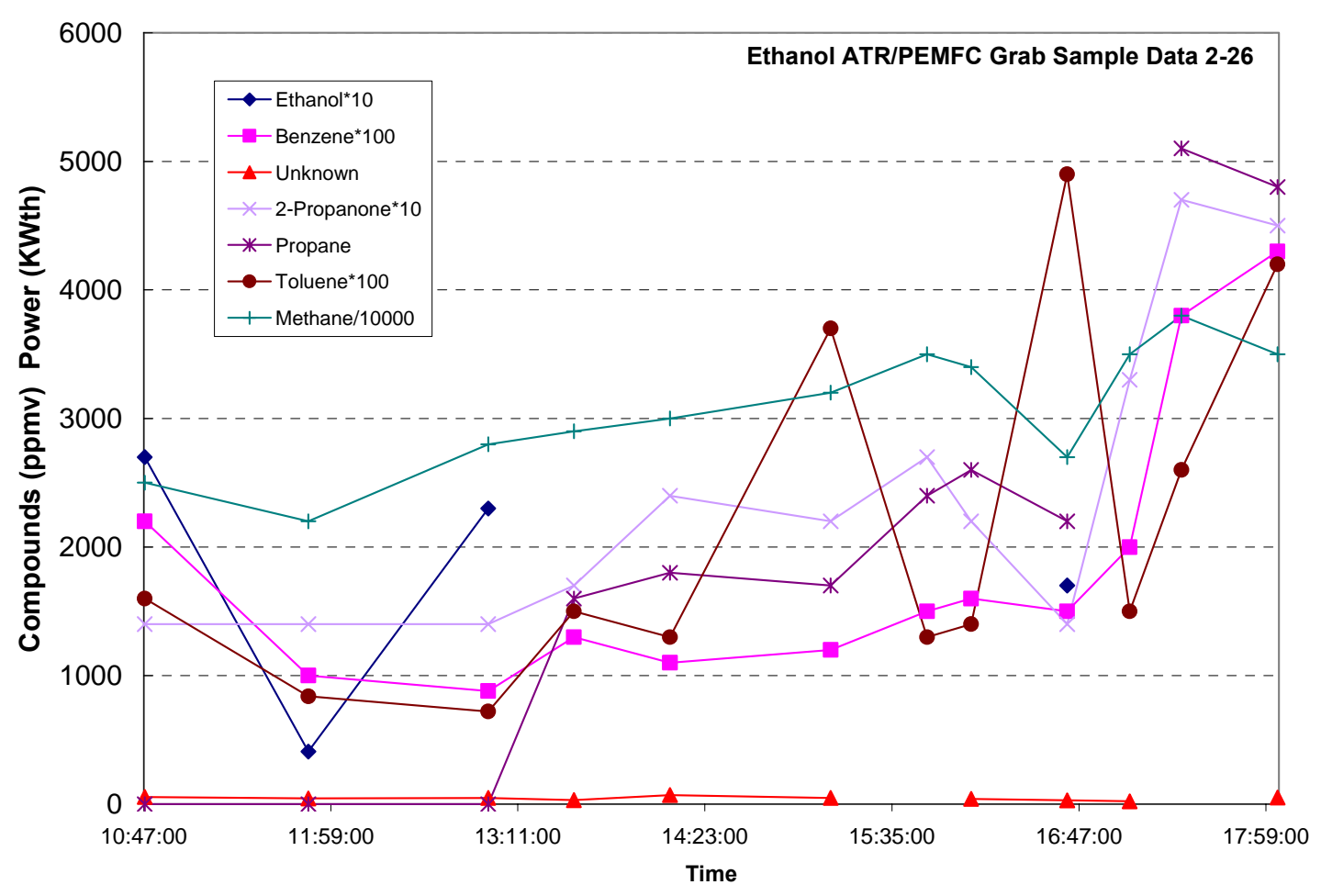

Figure C-3. Nuvera Ethanol ATR/PEMFC Speciation Summary (continued) 


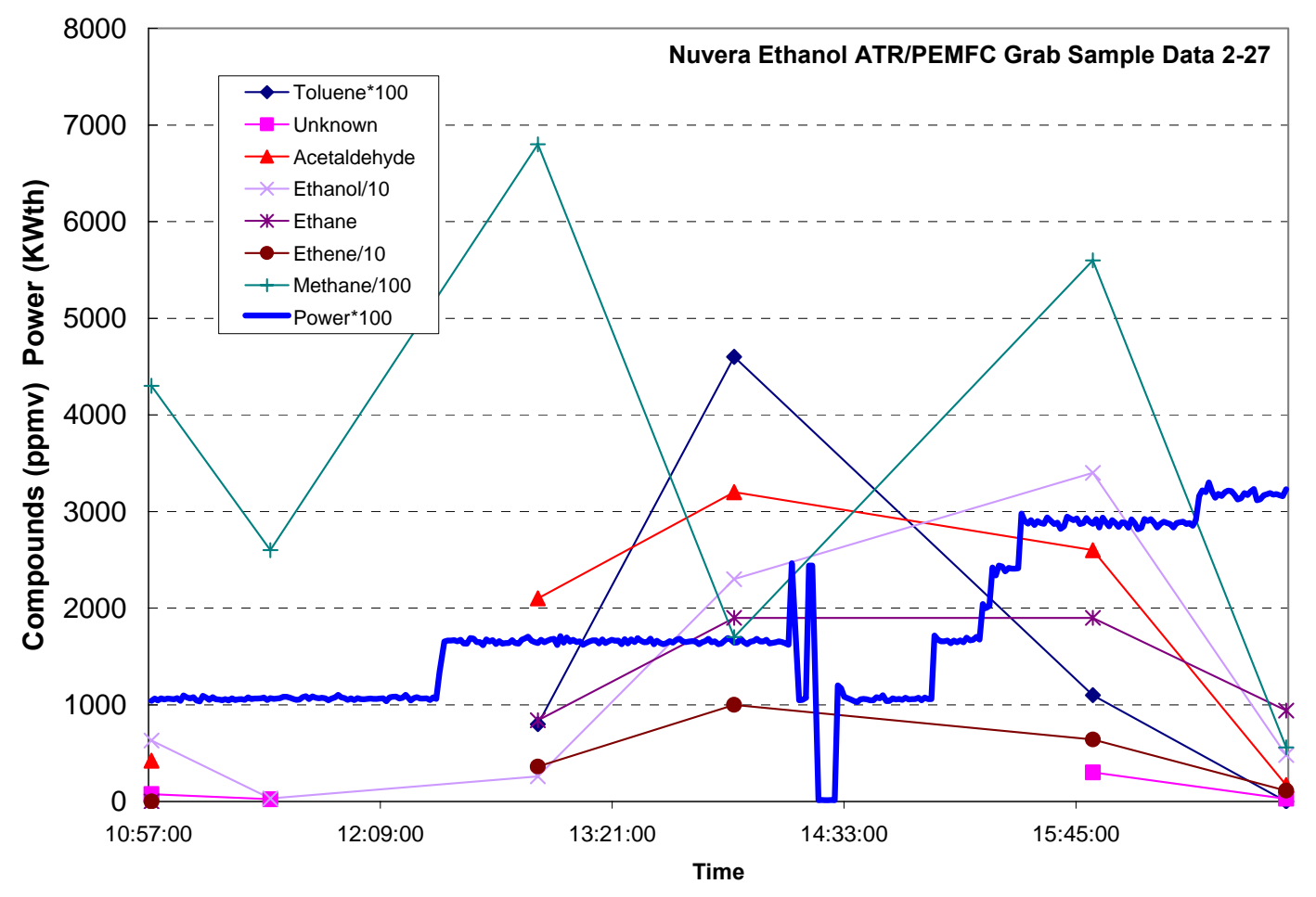

Figure C-3. Nuvera Ethanol ATR/PEMFC Speciation Summary (continued)

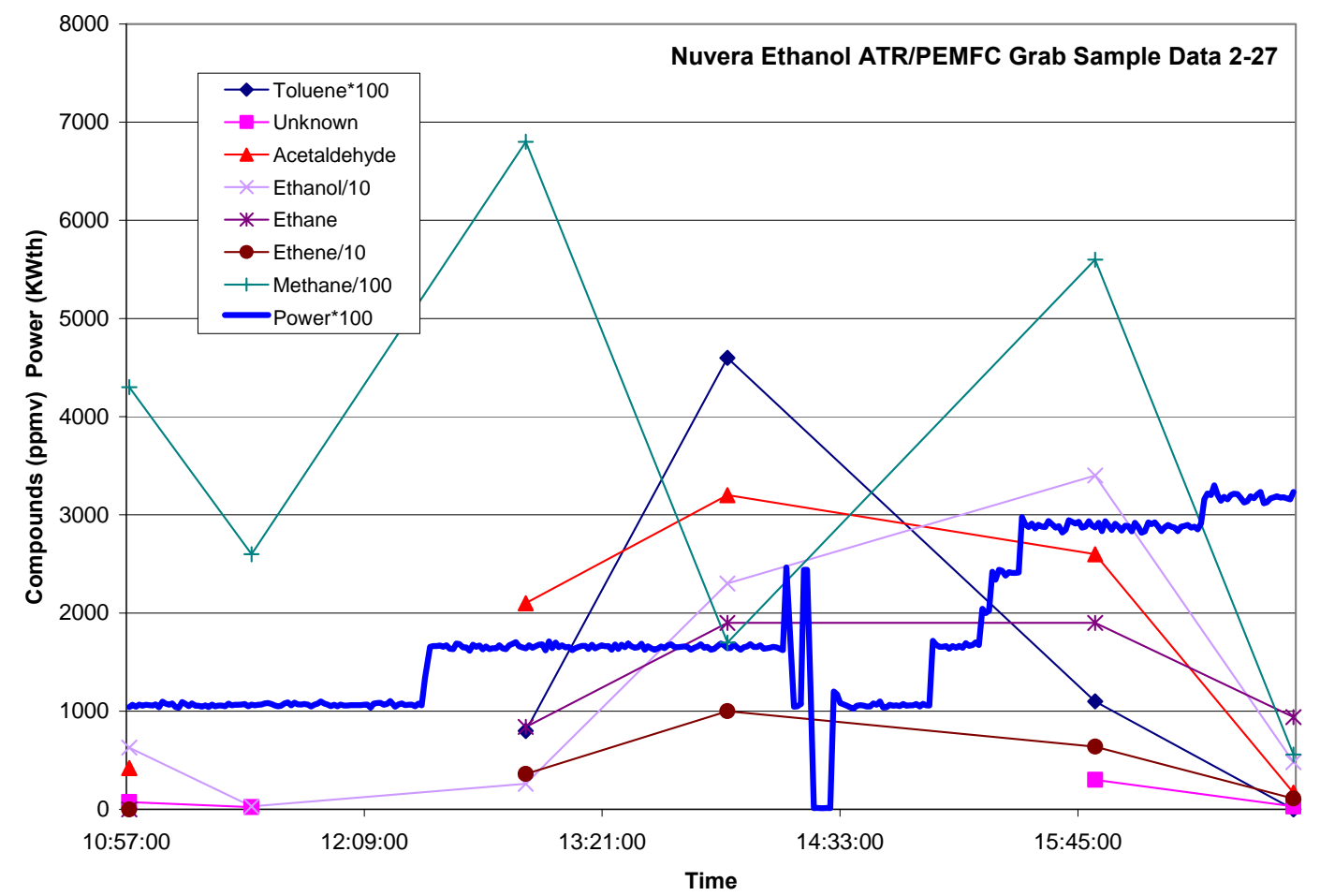

Figure C-3. Nuvera Ethanol ATR/PEMFC Speciation Summary (continued) 
Table C-5. Formaldehyde Emissions, Nuvera Ethanol ATR/PEMFC, Method Modified TO-5

\begin{tabular}{|c|c|c|c|c|}
\hline \multirow[b]{2}{*}{ Compound } & \multirow{2}{*}{$\begin{array}{l}\text { Sample } \\
\text { Volume } \\
\text { (dscfm) }\end{array}$} & \multirow{2}{*}{$\begin{array}{c}\text { Mass Collected } \\
\text { Sample } \\
(\mu \mathrm{g})\end{array}$} & \multicolumn{2}{|c|}{ Total } \\
\hline & & & ( $\mu \mathrm{g} / \mathrm{dscf})$ & $(\mu \mathrm{g} / \mathrm{dscm})$ \\
\hline $\begin{array}{l}\text { Test Date: } 2 / 26 / 03, N-D-F o r m-8 \\
\text { Formaldehyde }\end{array}$ & 0.77 & 1.3 & 1.69 & 59.61 \\
\hline $\begin{array}{l}\text { Test Date: 2/26/03, N-D-Form-12 } \\
\text { Formaldehyde }\end{array}$ & 0.9 & $<1.00$ & 1.11 & 39.23 \\
\hline $\begin{array}{l}\text { Test Date: } 2 / 26 / 03, N-D-F o r m-11 \\
\text { Formaldehyde }\end{array}$ & 0.58 & 0.54 & 0.93 & 32.87 \\
\hline $\begin{array}{l}\text { Test Date: } 2 / 26 / 03, N-D-F o r m-3 \\
\text { Formaldehyde }\end{array}$ & 1.15 & 1.2 & 1.04 & 36.85 \\
\hline $\begin{array}{l}\text { Test Date: } 2 / 26 / 03, N-D-F o r m-10 \\
\text { Formaldehyde }\end{array}$ & 0.58 & 0.56 & 0.97 & 34.09 \\
\hline $\begin{array}{l}\text { Test Date: } 2 / 27 / 03, N-C-F o r m-4 \\
\text { Formaldehyde }\end{array}$ & 0.73 & 43 & 58.90 & 2079.90 \\
\hline $\begin{array}{l}\text { Test Date: } 2 / 27 / 03, \text { N-C-Form-7 } \\
\text { Formaldehyde }\end{array}$ & 1.1 & 100 & 90.91 & 3210 \\
\hline $\begin{array}{l}\text { Test Date: } 2 / 27 / 03, \text { N-C-Form-1 } \\
\text { Formaldehyde }\end{array}$ & 0.64 & 11 & 17.19 & 606.89 \\
\hline
\end{tabular}


Table C-6. Hydrocarbon Speciation for Nuvera Gasoline Star ATR

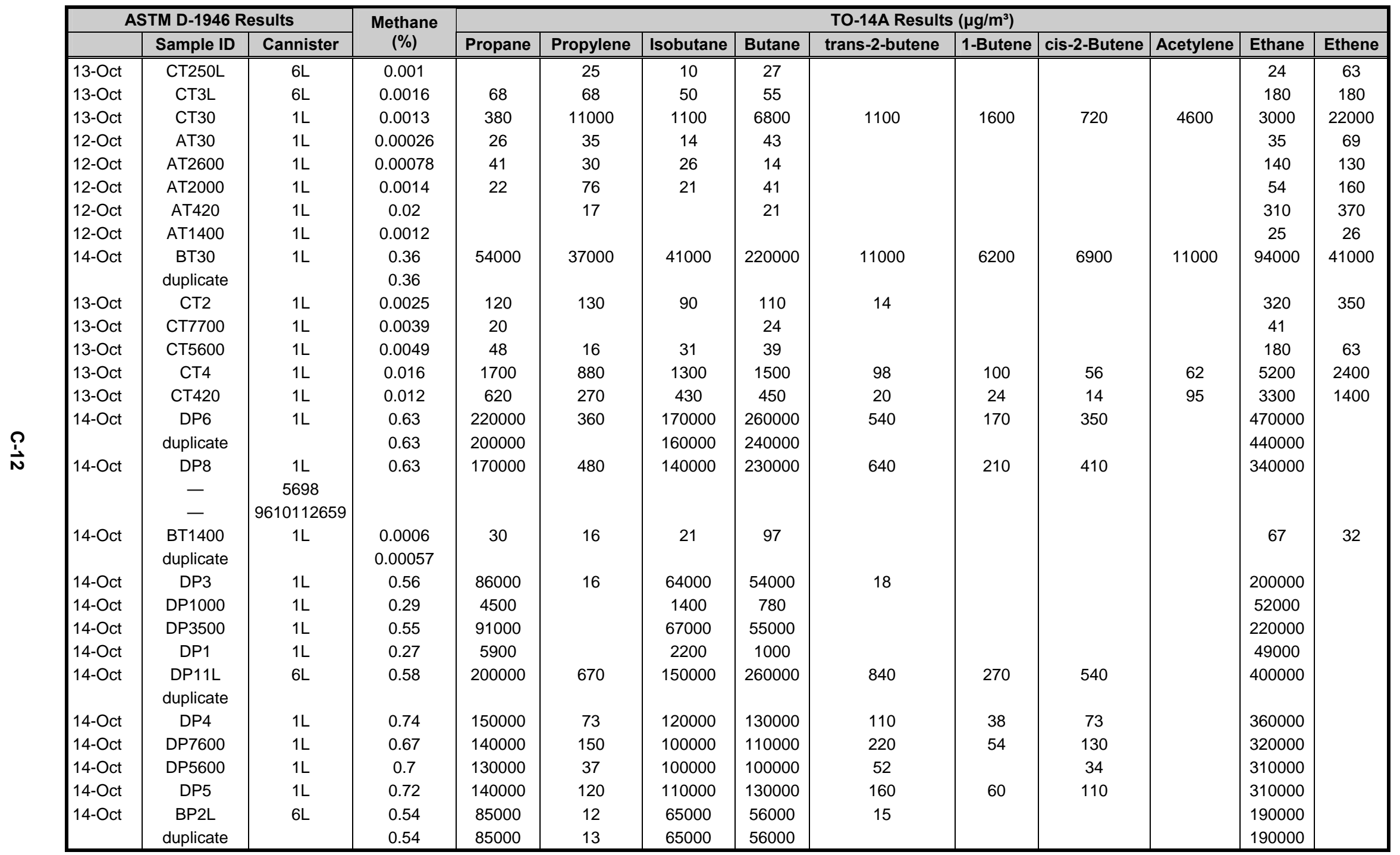


Table C-6. Hydrocarbon Speciation for Nuvera Gasoline Star ATR (concluded)

\begin{tabular}{|c|c|c|c|c|c|c|c|c|c|c|c|c|c|}
\hline \multicolumn{3}{|c|}{ ASTM D-1946 Results } & \multirow{2}{*}{$\begin{array}{c}\text { Methane } \\
(\%)\end{array}$} & \multicolumn{10}{|c|}{ TO-14A Results (ppbv) } \\
\hline & Sample ID & Cannister & & Propane & Propylene & Isobutane & Butane & trans-2-butene & 1-Butene & cis-2-Butene & Acetylene & Ethane & Ethene \\
\hline 13-Oct & $\overline{\mathrm{CCT} 250 \mathrm{~L}}$ & 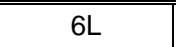 & 0.001 & & 14 & 4.2 & 11 & & & & & 20 & 55 \\
\hline 13-Oct & CT3L & $6 \mathrm{~L}$ & 0.0016 & 38 & 40 & 21 & 23 & & & & & 140 & 160 \\
\hline 13-Oct & СТ30 & $1 \mathrm{~L}$ & 0.0013 & 210 & 6300 & 460 & 2900 & 480 & 710 & 320 & 4400 & 2400 & 19000 \\
\hline 12-Oct & AT30 & $1 \mathrm{~L}$ & 0.00026 & 14 & 21 & 5.8 & 18 & & & & & 28 & 60 \\
\hline 12-Oct & АT2600 & $1 \mathrm{~L}$ & 0.00078 & 23 & 17 & 11 & 6 & & & & & 110 & 110 \\
\hline 12-Oct & AT2000 & $1 \mathrm{~L}$ & 0.0014 & 12 & 44 & 8.8 & 17 & & & & & 44 & 140 \\
\hline 12-Oct & AT420 & $1 \mathrm{~L}$ & 0.02 & & 9.7 & & 8.7 & & & & & 260 & 320 \\
\hline 12-Oct & AT1400 & $1 \mathrm{~L}$ & 0.0012 & & & & & & & & & 20 & 22 \\
\hline 14-Oct & Втз0 & $1 \mathrm{~L}$ & 0.36 & 30000 & 22000 & 17000 & 93000 & 4900 & 2700 & 3000 & 10000 & 76000 & 36000 \\
\hline & duplicate & & 0.36 & & & & & & & & & & \\
\hline 13-Oct & СТ2 & $1 \mathrm{~L}$ & 0.0025 & 67 & 76 & 38 & 46 & 6 & & & & 260 & 300 \\
\hline 13-Oct & СТ7700 & $1 \mathrm{~L}$ & 0.0039 & 11 & & & 10 & & & & & 34 & \\
\hline 13-Oct & CT5600 & $1 \mathrm{~L}$ & 0.0049 & 27 & 9.5 & 13 & 16 & & & & & 150 & 55 \\
\hline 13-Oct & CT4 & $1 \mathrm{~L}$ & 0.016 & 960 & 510 & 540 & 620 & 43 & 46 & 24 & 58 & 4200 & 2100 \\
\hline 13-Oct & CT420 & $1 \mathrm{~L}$ & 0.012 & 350 & 160 & 180 & 190 & 8.9 & 10 & 5.9 & 89 & 2700 & 1200 \\
\hline 14-Oct & DP6 & $1 \mathrm{~L}$ & 0.63 & 120000 & 210 & 72000 & 110000 & 240 & 74 & 150 & & 380000 & \\
\hline & duplicate & & 0.63 & 110000 & & 68000 & 99000 & & & & & 360000 & \\
\hline 14-Oct & DP8 & $1 \mathrm{~L}$ & 0.63 & 97000 & 280 & 61000 & 97000 & 280 & 92 & 180 & & 270000 & \\
\hline & $\begin{array}{l}- \\
-\end{array}$ & $\begin{array}{c}5698 \\
9610112659\end{array}$ & & & & & & & & & & & \\
\hline 14-Oct & $\begin{array}{l}\text { BT1400 } \\
\text { duplicate }\end{array}$ & $1 \mathrm{~L}$ & $\begin{array}{c}0.0006 \\
0.00057\end{array}$ & 17 & 9.3 & 8.8 & 41 & 4.8 & 4.8 & 4.8 & 12 & 55 & 28 \\
\hline $14-O c t$ & DP3 & $1 \mathrm{~L}$ & 0.56 & 13 & 13 & 18 & 18 & 17 & 17 & 17 & 20 & 23 & 21 \\
\hline 14-Oct & DP1000 & $1 \mathrm{~L}$ & 0.29 & 2500 & & 590 & 330 & & & & & 43000 & \\
\hline 14-Oct & DP3500 & $1 \mathrm{~L}$ & 0.55 & 51000 & & 28000 & 23000 & & & & & 180000 & \\
\hline 14-Oct & DP1 & $1 \mathrm{~L}$ & 0.27 & 3300 & & 910 & 430 & & & & & 40000 & \\
\hline 14-Oct & $\begin{array}{c}\text { DP11L } \\
\text { duplicate }\end{array}$ & $6 \mathrm{~L}$ & 0.58 & 110000 & 390 & 64000 & 110000 & 370 & 120 & 240 & & 320000 & \\
\hline 14-Oct & DP4 & $1 \mathrm{~L}$ & 0.74 & 84000 & 42 & 49000 & 54000 & 49 & 16 & 32 & & 300000 & \\
\hline 14-Oct & DP7600 & $1 \mathrm{~L}$ & 0.67 & 75000 & 88 & 44000 & 48000 & 94 & 24 & 58 & & 260000 & \\
\hline 14-Oct & DP5600 & $1 \mathrm{~L}$ & 0.7 & 72000 & 22 & 43000 & 44000 & 23 & & 15 & & 250000 & \\
\hline 14-Oct & DP5 & $1 \mathrm{~L}$ & 0.72 & 75000 & 68 & 47000 & 54000 & 71 & 26 & 46 & & 250000 & \\
\hline 14-Oct & BP2L & $6 \mathrm{~L}$ & 0.54 & 47000 & 6.8 & 27000 & 23000 & 6.4 & & & & 150000 & \\
\hline & duplicate & & 0.54 & 47000 & 7.4 & 27000 & 24000 & & & & & 150000 & \\
\hline
\end{tabular}


Table C-7. Hydrocarbon Speciation for Nuvera Gasoline Star ATR, Canister Samples (ppbv)

\begin{tabular}{|c|c|c|c|c|c|c|c|c|c|c|c|c|}
\hline Date & 14-Oct & 14-Oct & 14-Oct & 14-Oct & 14-Oct & 14-Oct & 14-Oct & 14-Oct & 14-Oct & 14-Oct & 14-Oct & 14-Oct \\
\hline Can Size & 1L & 1L & 1L & 1L & 1L & $6 \mathrm{~L}$ & $6 \mathrm{~L}$ & 1L & 1L & 1L & 1L & $6 \mathrm{~L}$ \\
\hline Sample ID\# & BT1400 & DP3 & DP1000 & DP3500 & DP1 & DP11L & duplicate & DP4 & DP7600 & DP5600 & DP5 & BP2L \\
\hline \multicolumn{13}{|l|}{ Test TO-15, O3 } \\
\hline Source File 0410376A & & 1 & & & & & & & & & & \\
\hline 1,2,3-Trimethylbenzene & 21 & & & & & & & & & & & \\
\hline 1,2,4-Trimethylbenzene & 82 & 1000 & 120 & 760 & 120 & 6600 & 6300 & 5200 & 4400 & 4500 & 2900 & 1100 \\
\hline 1,2-Dichloroethane-d4 & 104 & 113 & 101 & 96 & 111 & 116 & 113 & 110 & 112 & 111 & 108 & 110 \\
\hline 1,3,5-Trimethylbenzene & 22 & 430 & 48 & & 51 & 3000 & 2600 & 2100 & 1800 & 1900 & & 480 \\
\hline 1,3-Diethylbenzene & 10 & & & & & & & & & & & \\
\hline 1,4-Diethylbenzene & & & & & & & & & & & & \\
\hline 1-Hexene & & & & & & & & & & & & \\
\hline 1-Hexene, 5-methyl- & & & & & & & & & & & 7300 & \\
\hline 1H-Inden-5-ol, 2,3-dihydro- & & & & & & & & & & & & \\
\hline 1H-Indene, 1-methylene- & & & & & & & & & & & & \\
\hline 1H-Indene, 2,3-dihydro-1-methyl- & 95 & & & & & & & & & & & \\
\hline 1H-Indene, 2,3-dihydro-2-methyl- & & & & & & & & & & & & \\
\hline 1H-Indene, 2,3-dihydro-4,7-dimethyl- & & & & & & & & & & & & \\
\hline 1H-Indene, 2,3-dihydro-4-methyl- & & & & & & & & & & & & \\
\hline 1H-Tetrazole, 5-methyl- & & & & & & & & & 9200 & 8700 & & \\
\hline 1-Pentene & & & & & & & & & & & & \\
\hline 1-Pentene, 2-methyl- & & & & & 300 & & & 9800 & & & 11000 & \\
\hline 1-Propene, 2-methyl- & & & & & & & & & & & & \\
\hline 2,2,4-Trimethylpentane & 40 & 6300 & 2700 & 5800 & 2800 & 45000 & 45000 & 18000 & 18000 & 18000 & 16000 & 6100 \\
\hline 2,2-Dimethylbutane & 19 & 7000 & & 6400 & & 38000 & 37000 & 20000 & 18000 & 16000 & 17000 & 6900 \\
\hline 2,3,4-Trimethylpentane & 9.6 & & 490 & & 510 & & & & & & & \\
\hline 2,3-Dihydro-1-methylindene & & & & & & & & & & & & \\
\hline 2,3-Dimethylbutane & 24 & 5000 & 200 & 4500 & 200 & 35000 & 35000 & 16000 & 14000 & 11000 & 13000 & 5000 \\
\hline 2,3-Dimethylpentane & 18 & 2000 & 1100 & 2000 & 1100 & 14000 & 14000 & 4700 & 5400 & 5200 & & 1800 \\
\hline 2,4-Dimethylpentane & 15 & & 690 & & 640 & 13000 & 13000 & & & & & 1600 \\
\hline 2-Ethyltoluene & 16 & & & & & & & & & & & \\
\hline 2H-Pyran, tetrahydro-2-(2-propynyloxy)- & & & & & & & & & & & & \\
\hline 2-Methylheptane & 6.8 & & 270 & & 300 & & & & & & & \\
\hline 2-Methylhexane & 10 & & 600 & & 640 & 7400 & 7400 & & & & & \\
\hline 2-Methylpentane & 94 & 13000 & 880 & 12000 & 820 & 110000 & 110000 & 39000 & 38000 & 35000 & 35000 & 14000 \\
\hline 2-Propanone & & & & & & & & & & & & \\
\hline 3-Ethyltoluene & 44 & & & & & & & & & & & \\
\hline 3-Methylheptane & 9.0 & & 390 & & 420 & & & & & & & \\
\hline 3-Methylhexane & 13 & & 800 & & 780 & 9600 & 9100 & & & & & \\
\hline 3-Methylpentane & 72 & 9800 & 910 & 8800 & 830 & 78000 & 80000 & 30000 & 29000 & 26000 & 26000 & 10000 \\
\hline
\end{tabular}


Table C-7. Hydrocarbon Speciation for Nuvera Gasoline Star ATR, Canister Samples (ppbv) (continued)

\begin{tabular}{|c|c|c|c|c|c|c|c|c|c|c|c|c|}
\hline $\begin{array}{r}\text { Date } \\
\text { Can Size } \\
\text { Sample ID\# }\end{array}$ & $\begin{array}{c}\text { 14-Oct } \\
1 \mathrm{~L} \\
\text { BT1400 }\end{array}$ & $\begin{array}{l}\text { 14-Oct } \\
\text { 1L } \\
\text { DP3 }\end{array}$ & $\begin{array}{c}\text { 14-Oct } \\
1 \mathrm{~L} \\
\text { DP1000 }\end{array}$ & $\begin{array}{c}\text { 14-Oct } \\
1 \mathrm{~L} \\
\text { DP3500 }\end{array}$ & $\begin{array}{l}\text { 14-Oct } \\
1 \mathrm{~L} \\
\text { DP1 }\end{array}$ & $\begin{array}{l}\text { 14-Oct } \\
6 \mathrm{~L} \\
\text { DP11L }\end{array}$ & $\begin{array}{c}\text { 14-Oct } \\
6 \mathrm{~L} \\
\text { duplicate }\end{array}$ & $\begin{array}{l}\text { 14-Oct } \\
1 \mathrm{~L} \\
\text { DP4 }\end{array}$ & $\begin{array}{c}\text { 14-Oct } \\
1 \mathrm{~L} \\
\text { DP7600 }\end{array}$ & $\begin{array}{c}\text { 14-Oct } \\
1 \mathrm{~L} \\
\text { DP5600 }\end{array}$ & $\begin{array}{l}\text { 14-Oct } \\
\text { 1L } \\
\text { DP5 }\end{array}$ & $\begin{array}{l}14-O c t \\
6 \mathrm{~L} \\
\text { BP2L }\end{array}$ \\
\hline $\begin{array}{l}\quad \text { Test TO-15, } 03 \text { (continued) } \\
\text { Benzaldehyde } \\
\text { Benzaldehyde, 2-methyl- } \\
\text { Benzaldehyde, 3,4-dimethyl- } \\
\text { Benzaldehyde, 3-methyl- } \\
\text { Benzaldehyde, 4-ethyl- } \\
\text { Benzaldehyde, 4-methyl- } \\
\text { Benzaldehyde, ethyl- }\end{array}$ & & & & & & & & & & & & \\
\hline $\begin{array}{l}\text { Benzene } \\
\text { Benzene, 1,2,3,4-tetramethyl- } \\
\text { Benzene, 1,2,3,5-tetramethyl- } \\
\text { Benzene, 1,3,5-trimethyl-, isomer } \\
\text { Benzene, 1-ethyl-2,3-dimethyl- } \\
\text { Benzene, 1-ethyl-2,4-dimethyl- } \\
\text { Benzene, 1-ethyl-3,5-dimethyl- } \\
\text { Benzene, 1-methyl-2-(2-propenyl)- } \\
\text { Benzene, 1-methyl-3-(1-methylethyl)- } \\
\text { Benzene, 1-methyl-3-propyl- } \\
\text { Benzene, 2-ethyl-1,4-dimethyl- } \\
\text { Benzene, 4-ethyl-1,2-dimethyl- } \\
\text { Benzene, ethyl-1,2,4-trimethyl- } \\
\text { Benzene, methyl(1-methylethyl)- } \\
\text { Benzocycloheptatriene }\end{array}$ & $\begin{array}{c}13 \\
100 \\
130 \\
120 \\
110 \\
94\end{array}$ & 56000 & 5900 & 57000 & 6100 & 240000 & 240000 & 210000 & 200000 & 190000 & 160000 & 53000 \\
\hline $\begin{array}{l}\text { Butane } \\
\text { Butane, 2,2,3,3-tetramethyl- } \\
\text { cis-2-Pentene } \\
\text { Cumene }\end{array}$ & $\begin{array}{l}5.5 \\
3.0\end{array}$ & 39000 & 620 & 38000 & 790 & 170000 & 170000 & 94000 & 88000 & 84000 & 74000 & 40000 \\
\hline $\begin{array}{l}\text { Cyclohexane } \\
\text { Cyclopentane } \\
\text { Cyclopentene } \\
\text { Decane } \\
\text { Decane, 3,6-dimethyl- } \\
\text { Dodecane, 1-iodo- } \\
\text { Dodecane, 2-methyl-6-propyl- } \\
\text { Ethanone, 1-(2-methylphenyl)- } \\
\text { Ethanone, 1-phenyl- }\end{array}$ & 100 & 6400 & 5100 & 7000 & 4300 & $\begin{array}{r}3300 \\
19000\end{array}$ & $\begin{array}{l}10000 \\
16000\end{array}$ & 5600 & 2100 & 5200 & 4100 & 6800 \\
\hline Ethyl Benzene & 43 & 740 & 310 & 570 & 320 & 9000 & 9000 & 2700 & 2400 & 2200 & 2200 & 730 \\
\hline
\end{tabular}


Table C-7. Hydrocarbon Speciation for Nuvera Gasoline Star ATR, Canister Samples (ppbv) (concluded)

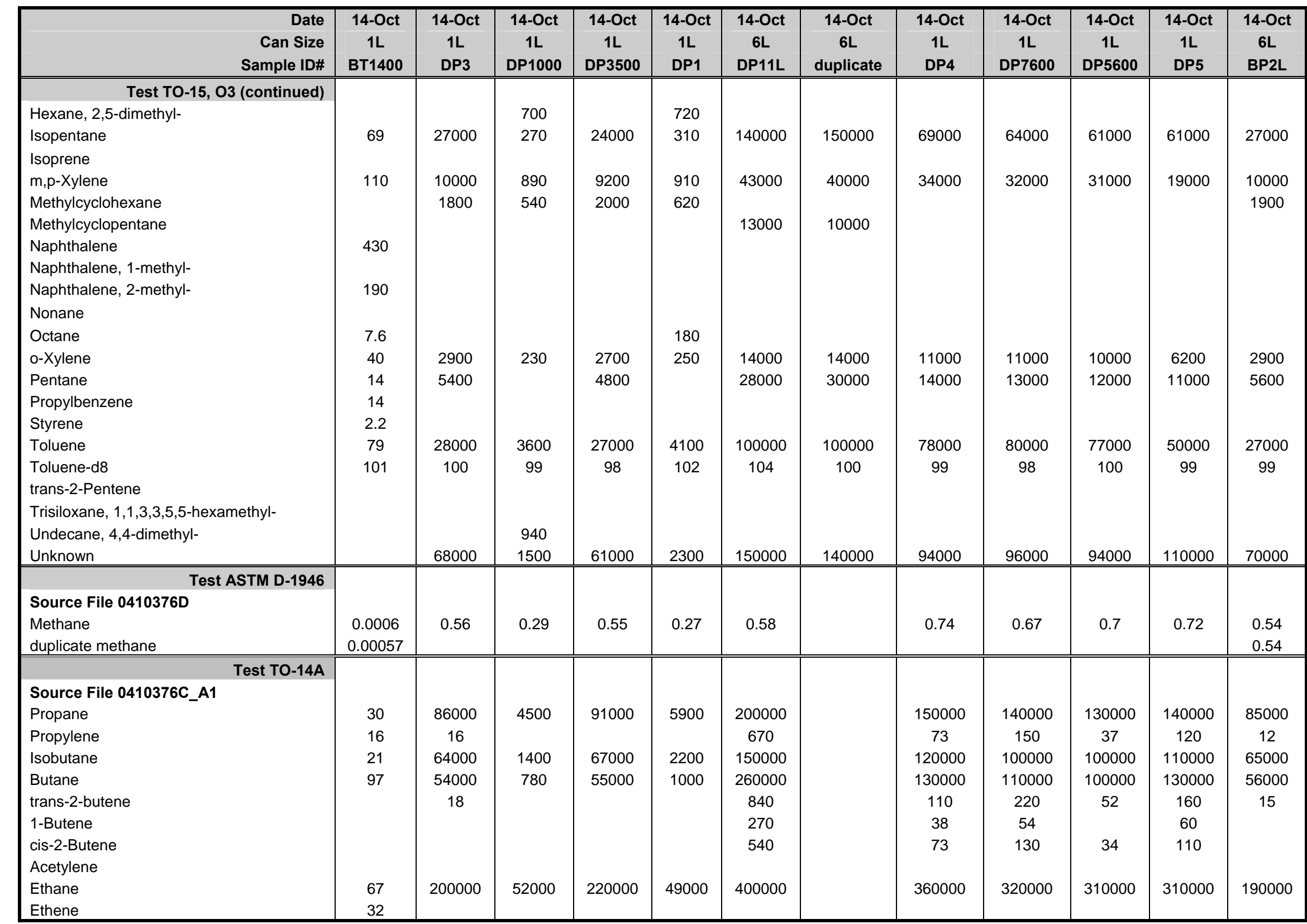


Table C-8. Hydrocarbon Speciation for Nuvera Gasoline Star ATR

\begin{tabular}{|c|c|c|c|c|c|c|c|c|c|c|c|c|c|c|c|c|}
\hline $\begin{array}{r}\text { Date } \\
\text { Can Size } \\
\text { Sample ID\# }\end{array}$ & $\begin{array}{c}\text { 13-Oct } \\
6 \mathrm{~L} \\
\text { CT250L }\end{array}$ & $\begin{array}{c}13-O c t \\
6 \mathrm{~L} \\
\text { CT3L }\end{array}$ & $\begin{array}{c}13-O c t \\
1 \mathrm{~L} \\
\text { СТ30 }\end{array}$ & $\begin{array}{c}12-\text { Oct } \\
1 \mathrm{~L} \\
\text { AT30 }\end{array}$ & $\begin{array}{c}\text { 12-Oct } \\
1 \mathrm{~L} \\
\text { AT2600 }\end{array}$ & 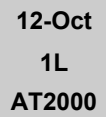 & $\begin{array}{c}\text { 12-Oct } \\
1 \mathrm{~L} \\
\text { AT420 }\end{array}$ & 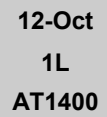 & $\begin{array}{c}14-\text { Oct } \\
1 \mathrm{~L} \\
\text { BT30 }\end{array}$ & $\begin{array}{c}\text { 13-Oct } \\
1 \mathrm{~L} \\
\text { СT2 }\end{array}$ & $\begin{array}{c}\text { 13-Oct } \\
1 \mathrm{~L} \\
\text { CT7700 }\end{array}$ & $\begin{array}{c}13-\text { Oct } \\
1 \mathrm{~L} \\
\text { CT5600 }\end{array}$ & $\begin{array}{c}13-\text { Oct } \\
1 \mathrm{~L} \\
\text { CT4 }\end{array}$ & $\begin{array}{c}13-\text { Oct } \\
1 \mathrm{~L} \\
\text { CT420 }\end{array}$ & $\begin{array}{c}\text { 14-Oct } \\
1 \mathrm{~L} \\
\text { DP6 }\end{array}$ & $\begin{array}{c}14-O c t \\
1 \mathrm{~L} \\
\text { DP8 }\end{array}$ \\
\hline Test & & & & & & & & & & & & & & & & \\
\hline Source File 0410378A & & & & & & & & & & & & & & & $0410381 A$ & \\
\hline 1,2,3-Trimethylbenzene & 3.7 & & 120 & & & & & & & & 17 & 20 & & 120 & 3.7 & \\
\hline 1,2,4-Trimethylbenzene & 16 & 7.9 & 570 & 23 & & & 7.1 & 2.5 & 18000 & 19 & 70 & 93 & 66 & 480 & 16 & 7.9 \\
\hline 1,2-Dichloroethane-d4 & 108 & 102 & 106 & 97 & 94 & 95 & 99 & 103 & 99 & 105 & 101 & 98 & 99 & 100 & 108 & 102 \\
\hline 1,3,5-Trimethylbenzene & 4.6 & 2.0 & 180 & 6.2 & & & 1.9 & & 6600 & 4.5 & 19 & 26 & 21 & 120 & 4.6 & 2.0 \\
\hline 1,3-Diethylbenzene & & & & & & & & & & & 7.6 & 7.1 & & 37 & & \\
\hline 1,4-Diethylbenzene & & & & & & & & & 5000 & & & & & & & \\
\hline 1-Hexene & & & & & & & & & & & & & & & & \\
\hline 1-Hexene, 5-methyl- & & & & & & & & & & & & & & & & \\
\hline 1H-Inden-5-ol, 2,3-dihydro- & 49 & & & & & & & & & & & & & & 49 & \\
\hline 1H-Indene, 1-methylene- & 110 & & & & & & & & & & & 98 & & & 110 & \\
\hline 1H-Indene, 2,3-dihydro-1-methyl- & & & & & & & & & & & & & & 270 & & \\
\hline 1H-Indene, 2,3-dihydro-2-methyl- & & & & & & & & & & & 50 & & & & & \\
\hline 1H-Indene, 2,3-dihydro-4,7-dimethyl- & & & & & & & & & & & 110 & & & & & \\
\hline 1H-Indene, 2,3-dihydro-4-methyl- & & & & & & & & & & 20 & & & & & & \\
\hline 1H-Tetrazole, 5-methyl- & & & & & & & & & & & & & & & & \\
\hline 1-Pentene & & & 82 & & & & & & & & & & 52 & & & \\
\hline 1-Pentene, 2-methyl- & & & & & & & & & & & & & & & & \\
\hline 1-Propene, 2-methyl- & & & 3300 & & & 32 & & & 28000 & 27 & & & 450 & & & \\
\hline 2,2,4-Trimethylpentane & 9.1 & 6.8 & 1000 & 12 & & 8.5 & 11 & & 52000 & 10 & 5.1 & 7.0 & 260 & 77 & 9.1 & 6.8 \\
\hline 2,2-Dimethylbutane & 4.0 & 7.9 & 680 & & & 6.9 & & & 30000 & 12 & & 6.0 & 290 & 80 & 4.0 & 7.9 \\
\hline 2,3,4-Trimethylpentane & & & 220 & & & & & & & & & & & & & \\
\hline 2,3-Dihydro-1-methylindene & & 12 & & & & & 7.8 & & & & & 35 & 63 & & & 12 \\
\hline 2,3-Dimethylbutane & 6.4 & 5.9 & 750 & 5.8 & & 7.0 & 6.5 & & 38000 & 9.8 & & 5.4 & 220 & 56 & 6.4 & 5.9 \\
\hline 2,3-Dimethylpentane & 4.7 & & 480 & 5.8 & & & 5.9 & & 27000 & & & & 79 & 26 & 4.7 & \\
\hline 2,4-Dimethylpentane & 3.5 & & 390 & & & & 5.2 & & 22000 & & & & 64 & 20 & 3.5 & \\
\hline 2-Ethyltoluene & 3.3 & & 160 & & & & & & 5100 & & 14 & 18 & 63 & 84 & 3.3 & \\
\hline 2H-Pyran, tetrahydro-2-(2-propynyloxy)- & & & & & & & & & & & & & & & & \\
\hline 2-Methylheptane & & & 130 & & & & & & 7400 & & & & 40 & 16 & & \\
\hline 2-Methylhexane & & & 240 & & & & & & 14000 & & & & & & & \\
\hline 2-Methylpentane & 24 & 17 & 2900 & 25 & & 18 & 29 & 10 & 150000 & 26 & 14 & 16 & 580 & 160 & 24 & 17 \\
\hline 2-Propanone & & & & & & 16 & & & & & & & & & & \\
\hline 3-Ethyltoluene & 9.9 & 4.0 & 480 & 14 & & & & & 15000 & 9.3 & 41 & 55 & & 250 & 9.9 & 4.0 \\
\hline 3-Methylheptane & & & 150 & & & & & & 10000 & & & & & 23 & & \\
\hline 3-Methylhexane & 9.2 & & 300 & 5.2 & & & & & 18000 & & & & 50 & 18 & 9.2 & \\
\hline 3-Methylpentane & 19 & 14 & 2200 & 19 & & 15 & 22 & 8.1 & 110000 & 21 & 10 & 13 & 450 & 120 & 19 & 14 \\
\hline 4-Azabenzimidazole & & & & & & & & & & & & 34 & & & & \\
\hline 4-Bromofluorobenzene & 97 & 99 & 97 & 97 & 95 & 97 & 98 & 96 & 98 & 100 & 96 & 97 & 97 & 99 & 97 & 99 \\
\hline
\end{tabular}


Table C-8. Hydrocarbon Speciation for Nuvera Gasoline Star ATR (continued)

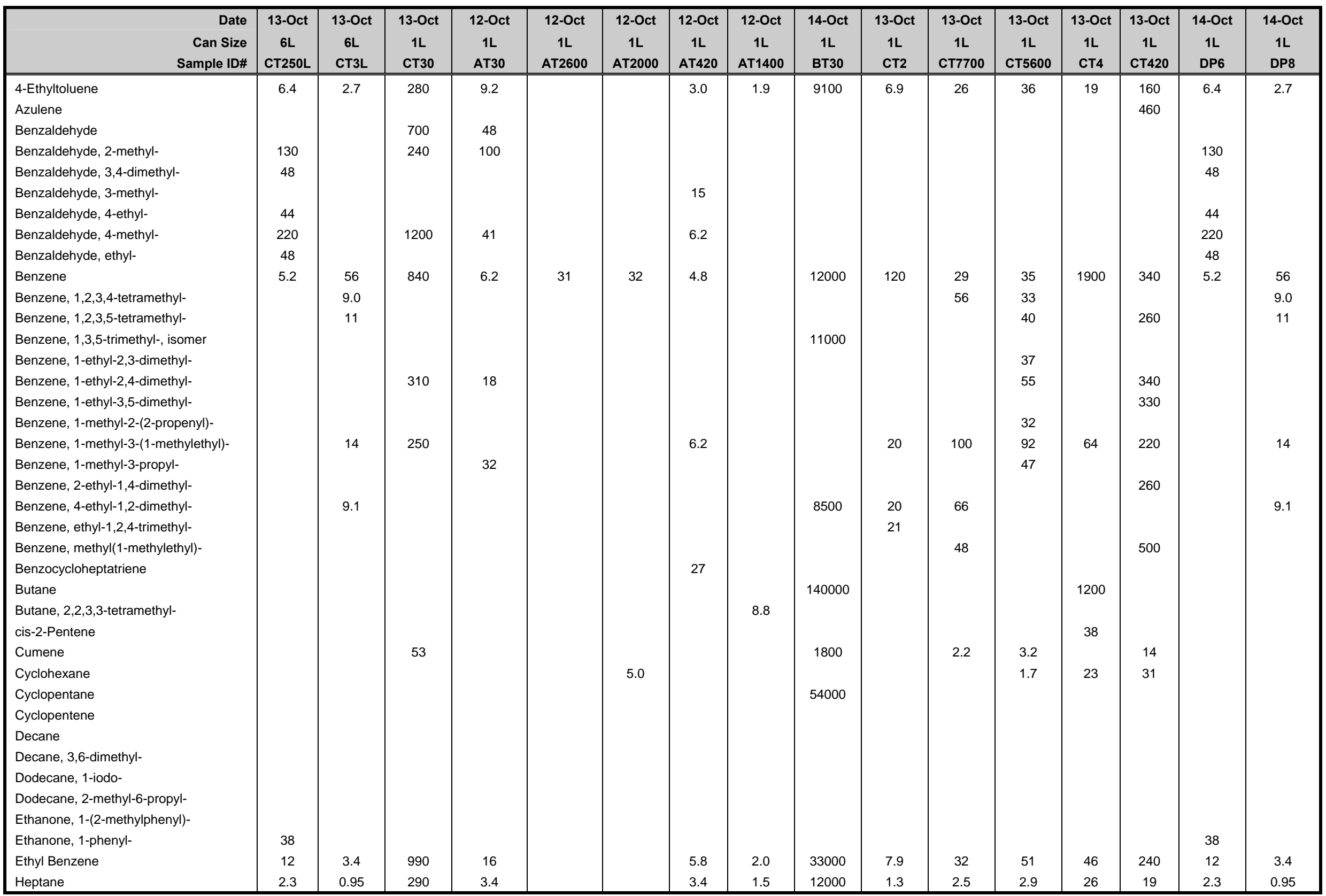


Table C-8. Hydrocarbon Speciation for Nuvera Gasoline Star ATR (concluded)

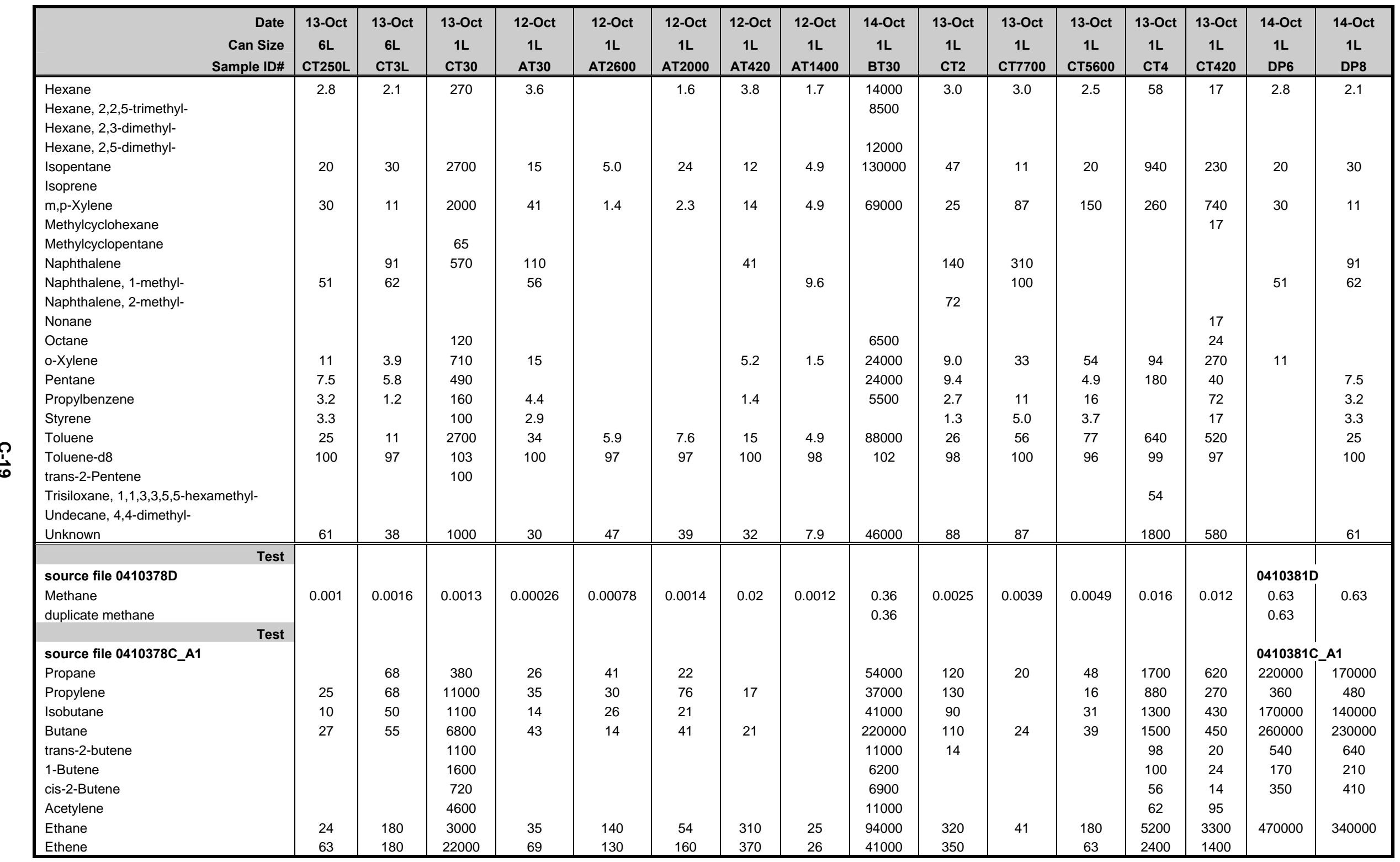


Table C-9. Formaldehyde Test Results, Nuvera Star Gasoline ATR, Method Modified TO-5

\begin{tabular}{|c|c|c|c|c|}
\hline \multirow[b]{2}{*}{ Compound } & \multirow{2}{*}{$\begin{array}{l}\text { Sample } \\
\text { Volume } \\
\text { (dscfm) }\end{array}$} & \multirow{2}{*}{$\begin{array}{c}\text { Mass Collected } \\
\text { Sample } \\
(\mu \mathrm{g})\end{array}$} & \multicolumn{2}{|c|}{ Total } \\
\hline & & & ( $\mu \mathrm{g} / \mathrm{dscf})$ & $(\mu \mathrm{g} / \mathrm{dscm})$ \\
\hline Test Date: 10/14/04, N2-B-Form-1300 & & & & \\
\hline Formaldehyde & 2.39 & 14.0 & 5.85 & 206.52 \\
\hline Test Date: 10/13/04, N2-C-Form-3700 & TGC & & & \\
\hline Formaldehyde & 1.31 & 1.9 & 1.46 & 51.38 \\
\hline Test Date: 10/13/04, N2-C-Form-7600 & TGC & & & \\
\hline Formaldehyde & 1.04 & 16.0 & 15.34 & 541.77 \\
\hline Test Date: 10/13/04, N2-C-Form-5500 & TGC & & & \\
\hline Formaldehyde & 1.16 & 49.00 & 42.29 & 1493.13 \\
\hline Test Date: 10/14/04, N2-D-Form-1600 & PrOx & & & \\
\hline Formaldehyde & 1.57 & 1.50 & 0.95 & 33.70 \\
\hline $\begin{array}{l}\text { Test Date: 10/14/04, N2-D-Form-1600 } \\
\text { (duplicate) }\end{array}$ & PrOx & & & \\
\hline Formaldehyde & 1.57 & 2.10 & 1.34 & 47.18 \\
\hline Test Date: 10/14/04, N2-D-Form-3700 & PrOx & & & \\
\hline Formaldehyde & 1.55 & 2.80 & 1.81 & 64 \\
\hline Test Date: 10/14/04, N2-D-Form-7900 & PrOx & & & \\
\hline Formaldehyde & 1.85 & 11.00 & 5.96 & 210 \\
\hline
\end{tabular}

Table C-10. Ammonia Concentrations, Nuvera Star ATR 2004 Reformer

\begin{tabular}{|c|c|c|}
\hline Sample & Result & RL (mg/L) \\
\hline N2-A-Am-2500 & ND & 0.01 \\
N2-A-Am-1900 & ND & 1.01 \\
N2-C-Am-1 & ND & 2.01 \\
N2-D-Am-5800 & ND & 3.01 \\
N2-C-Am-7900 & ND & 4.01 \\
N2-D-Am-3400 & ND & 5.01 \\
N2-C-Am-5800 & ND & 6.01 \\
N2-D-Am-5500 & ND & 7.01 \\
N2-A-Am-1300 & ND & 8.01 \\
\hline
\end{tabular}

Curtis \& Thompkins - Ammonia Lab Analysis, October 2004 


\section{Table C-11. Weight of Particulate Collected Nuvera Star Gasoline ATR}

Date 10/15/2004

$100 \%$ load

\begin{tabular}{|c|c|c|c|c|}
\hline \multicolumn{3}{|c|}{ N2-E-PM-5500 } & \multicolumn{2}{|l|}{ time } \\
\hline R1 & $\#$ & Gross (g) & Tare $(\mathrm{g})$ & Net (g) \\
\hline Filter & 94 & 1.2873 & 1.2843 & 0.0030 \\
\hline
\end{tabular}

\begin{tabular}{|l|l|l|l|l|}
\multicolumn{1}{c}{} & \multicolumn{3}{c}{ time 1430} \\
R2 & $\#$ & Gross $(\mathrm{g})$ & Tare $(\mathrm{g})$ & Net $(\mathrm{g})$ \\
\hline Filter & 98 & 1.2903 & 1.2888 & 0.0015 \\
\hline
\end{tabular}

$75 \%$ load

\begin{tabular}{|c|c|c|c|c|}
\hline \multicolumn{3}{|c|}{ N2-E-OM-3400 } & \multicolumn{2}{|l|}{ time } \\
\hline R1 & \# & Gross (g) & Tare (g) & Net $(g)$ \\
\hline Filter & 93 & 1.2907 & 1.2850 & 0.0057 \\
\hline
\end{tabular}

\begin{tabular}{|l|l|l|l|l|}
\multicolumn{3}{c}{} & \multicolumn{3}{c}{ time 1354} \\
R2 & $\#$ & Gross $(\mathrm{g})$ & \multicolumn{1}{c}{ Tare $(\mathrm{g})$} & Net $(\mathrm{g})$ \\
\hline Filter & 97 & 1.2967 & 1.2955 & 0.0012 \\
\hline
\end{tabular}

\begin{tabular}{|c|c|c|c|c|c|c|c|c|c|}
\hline \multicolumn{10}{|c|}{$50 \%$ load } \\
\hline \multicolumn{3}{|c|}{ N2-E-PM-1300 } & \multicolumn{5}{|l|}{ time } & \multicolumn{2}{|c|}{ time 1319} \\
\hline R1 & $\#$ & Gross (g) & Tare (g) & Net (g) & $\mathrm{R} 2$ & $\#$ & Gross (g) & Tare $(\mathrm{g})$ & Net $(g)$ \\
\hline Filter & 92 & 1.2920 & 1.2887 & 0.0033 & Filter & 96 & 1.2876 & 1.2857 & 0.0019 \\
\hline
\end{tabular}

\begin{tabular}{|c|c|c|c|c|}
\hline \multicolumn{5}{|c|}{$25 \%$ load } \\
\hline N2-E-PM-30 & & & time & \\
\hline R1 & $\#$ & Gross (g) & Tare $(\mathrm{g})$ & Net $(\mathrm{g})$ \\
\hline Filter & 91 & 1.2909 & 1.2813 & 0.0096 \\
\hline Blank & \# & Gross (g) & Tare $(\mathrm{g})$ & Net $(g)$ \\
\hline Filter & 99 & 1.2891 & 1.2881 & 0.0010 \\
\hline
\end{tabular}

